$$
\begin{aligned}
& \text { 591.1078 } \\
& \text {. Sa93 }
\end{aligned}
$$





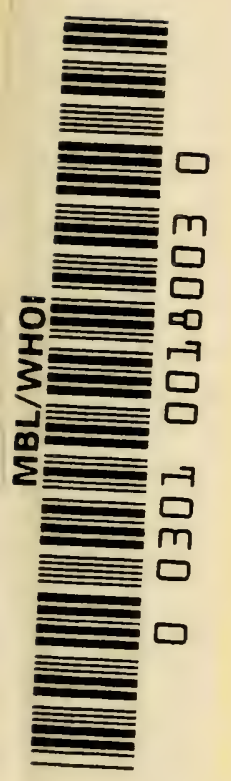


THE ECOLOGY AND

LIFE HISTORY OF THE

COMMON FROG 



\section{THE ECOLOGY AND LIFE HISTORY OF THE COMMON FROG (Rana temporaria temporaria)}

R. MAXWELL SAVACBE M.A.(Cantab), Ph.1).(Lond), F.R.I.C.

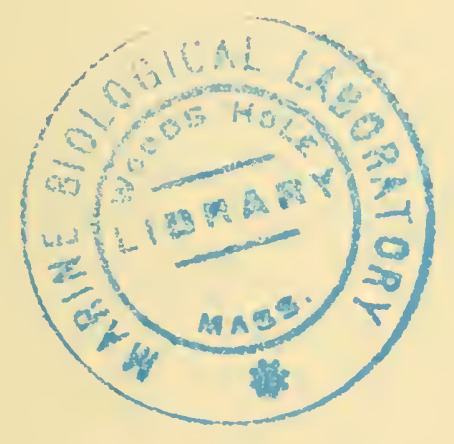

HAFNER PUBLISHING CO.

NEW YORK 1962 
Published in Great Britain by Sir Isaac Pitman E Sons Ltd.

(C)

R. Maxivell Savage

I96I 
IT is common for an author to explain in his preface that he has written his book for some particular class of persons. Critics sometimes wonder artlessly why a book has been written at all. I can be quite clear about all this: I wrote the book for myself.

I have no recollection of a time when I was not interested in zoology in general and the Amphibia in particular. Choosing the commonest in my neighbourhood, I have spent about thirty years studying the Common Frog and its tadpoles. Most of this work was ccological, but there were excursions into bchaviour, biochemistry, parasitology, anatomy and physiology, for the life of an animal requires for its illumination any scientific technique that can be brought to bear. I did this to please myself. Having reached a point when one of the major problems had received a solution, in the partial and temporary way that scientific problems are usually solved, I decided to put into effect a long-considered plan, and write a book to please myself. If anyone looks over my shoulder at what I have written, the publishers and I hope that he will be pleased, too.

It will naturally be found that some parts of the book are much more difficult than others. It is fortunate that the lives of animals bear so many resemblances to our own that everyday language can often be used, and is indeed often better than special technical terms, which in ecology seem to change their meaning. The book, however, is not artificially simplified, and I have dealt with some necessarily complicated aspects of the subject by explaining as I go along, or by including the more detailed matter in the final chapter on methods, or in Appendixes. The narrative is continuous: it is not a textbook to be studied, but rather a story to be read.

Most of the matter has already been published, either by mysclf or by others, in various scientific journals, but some is here presented for the first time. For example, the obscrvations in Chapter I on the formation of the jelly envelope of the egg, although very incomplete, are new, and so is a large part of Chapter 8 , in which the relation between the date of spawning and the weather is investigated. In this chapter and in Chapter Io, will be found what I believe to be the first account of methods of ecological investigation of voluminous data 
which could be extended to many other animals, using only information that already exists in great quantity. It is my hope that others may thus be encouraged to undertake such work, which in my view could lead to new discoveries, obtained direct from field data.

When I came to consider what acknowledgements I should make to those who have helped in the production of the results and of this book, I was oppressed by the debt I owed to so many. The references give an insufficient indication of this, for I have only included those that bear directly on the matter under discussion, and I must have omitted many that could have been mentioned. I therefore decided to confine myself to actions of particular value to one who, like myself, works on this subject in isolation as a recreation. It is always necessary to spend a good deal of time in libraries, but the pleasant custom of exchanging reprints with other herpetologists has led over the years to a collection that I have been able to study whenever I felt inclined, at home. To those who have sent me reprints, I should like to say how useful these have been.

Finally, I must pay a tribute to Dr. W. H. Parker, until recently Keeper of Zoology at the British Museum (Natural History). As a young man returning with some Bombina variegata from a holiday in France, and having made some observations on these animals, I was directly encouraged by a young Assistant Keeper in the Reptile department to publish the results, and to go on and do more. Dr. Parker is a taxonomist, and I, as a student of one or a few animals, had little need of taxonomic assistance, so that there might seem to be little direct connexion between this book and Dr. Parker's work, but that is, in fact, how it all began, for Dr. Parker was the young Assistant Keeper. 


\section{CONTENTS}

CHAP.

Preface.

I. The Eggs and Young Tadpoles . . . . . I

2. The General Life History of the Tadpoles. . 24

3. The Relation between the Ecology of Tadpoles and their Anatomy and Physiology . . . . 44

4. Parasites, Predators and some Problems of Abundance $5 \delta$

5. The Life of the Juvenile Frog . . . . . 67

6. Distribution and Abundance of the "Temporary Frog". 70

7. Food, Hibernation and Migration . . . . 94

8. The Influence of External Factors on the Spawn Date. izo

9. The Breeding Behaviour of the Frog . . . . IS3

IO. METHODS .

Appendix i. Statistical Methods . . . . . 203

Appendix 2. Glossary . . . . . . . . 2II

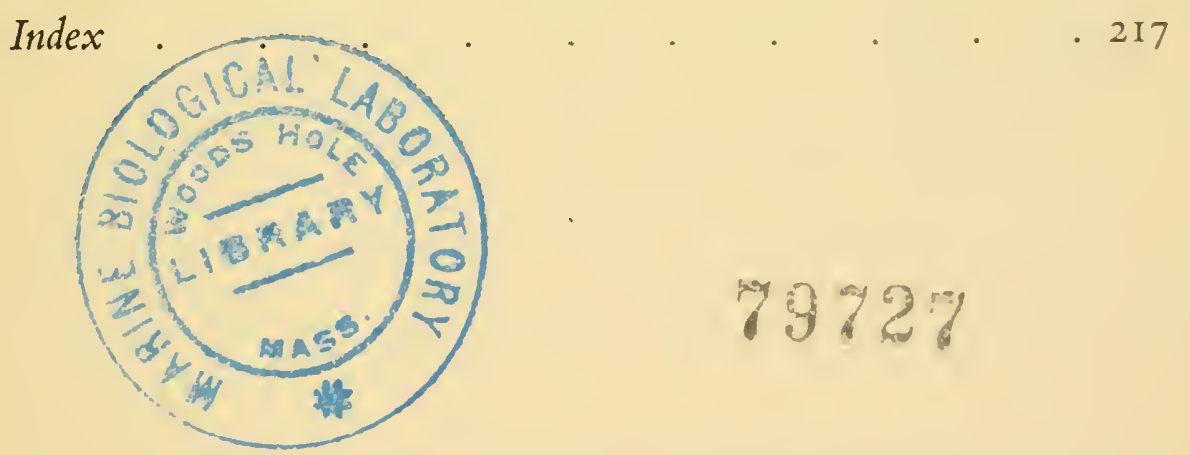





\section{Chapter I}

\section{THE EGGS AND YOUNG TADPOLES}

THIs book is an account of the life of the frog, planned as a complete circle: complete, that is to say, in the same sense as a megalithic stone circle is complete. The circle comes round again to the starting-point, but there are gaps in it.

Before this plan can even be started, a decision has to be made: which comes first, the frog or the egg? I have chosen to put the egg first, so that this chapter begins with an account of the jelly cnvelopes and the part that these play in the ecology of the animals. If anyone wishes to know how these eggs are laid, he must turn to Chapter 9, for surely this is the "other end" of the circle.

\section{The Connexion between the Distribution Range and the Properties of the Eggs}

The frog is an inhabitant of cold climates. Fig. I shows its distribution, and it can be seen that it ranges very far north, even beyond the Arctic Circle. In the more southern parts of its range, it becomes an inhabitant of the high mountains. In the Alps, for example, it may be found not far below the permanent snow line, at altitudes of over 2,500 metres where the snow only clears for just long enough for the tadpoles to completc their metamorphosis before wintry conditions set in at the end of September. In the Pyrences, Balcells (1956) has described colonies of this species on the Spanish side, although this frog does not occur in the parts of France adjacent to these mountains.

It breeds very early in the year, often as soon as the ice has gone from its ponds, and sometimes even when it has not all melted, so that frogs may be seen breeding in one part of a pond that still has ice or snow in another place.

How low a temperature the eggs can stand does not secm to have been determined, but Fischer-Sigwart (1897) says that eggs frozen through can still develop, and Douglas (1948) states that the eggs can withstand $0^{\circ} \mathrm{C}$ for at least twelve hours, so that the thermal death point must lie below this temperature. But wherever the actual point may lie, it is clear that the habit of the adults in spawning at such an early 
season must carry with it the risk of death for the eggs, if the weather should prove unfavourable.

There is a natural tendency to consider that early spawning is an advantage, so that an area in which frogs spawn early is considered to be

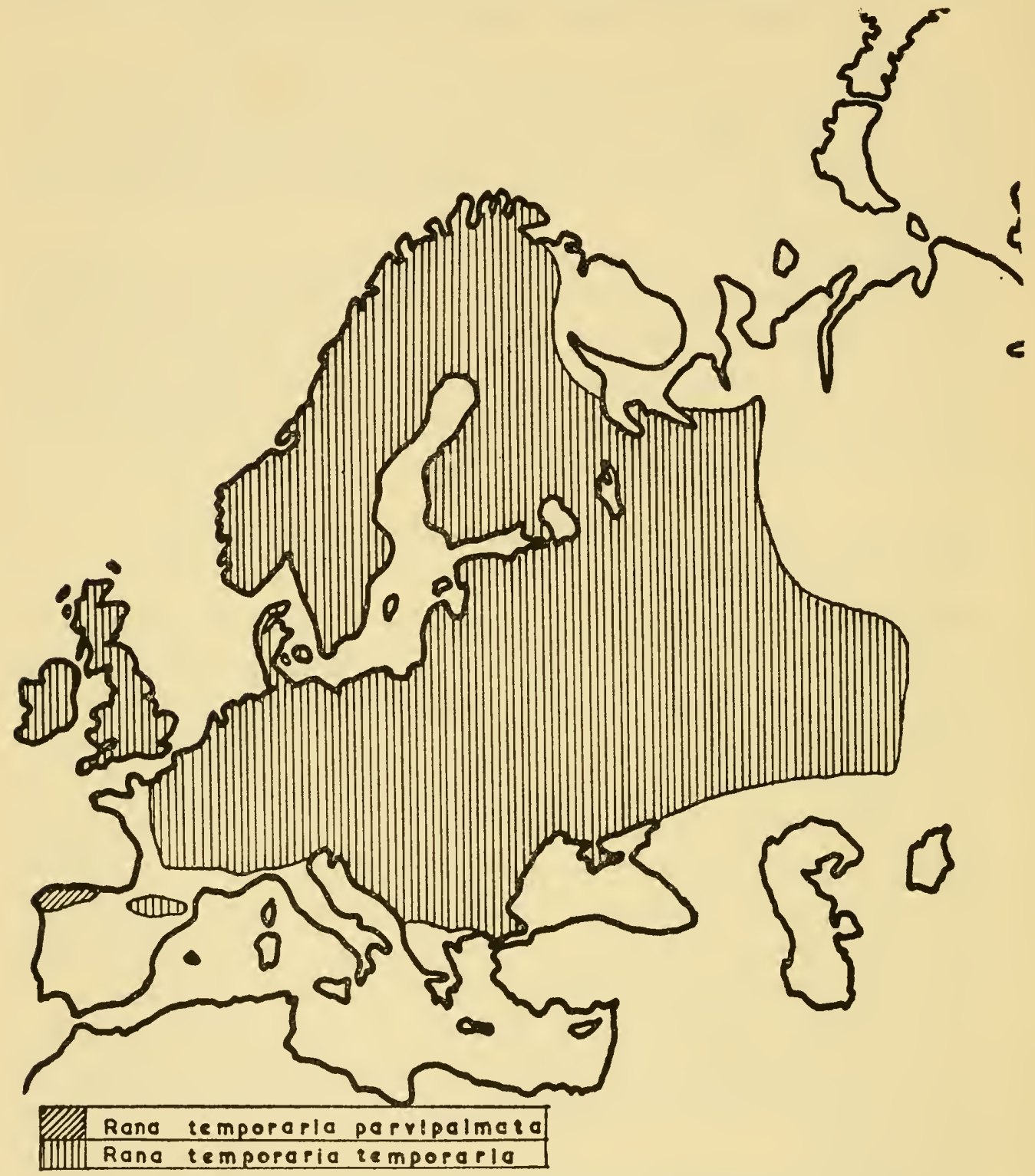

FIG. I. Map Showing the Distribution of the Common Frog in Europe

better for the animals than another area where spawning is much later. This, however, is not necessarily true. Other species of Anura spawn at other times, often during the summer when there is no danger from frost. Moore (I939) is surely right in thinking that each species must be 
regarded as having its own special requirements, best met by spawning at some particular season. We do not yet understand what these special requirements are in each case but we may be sure that the forces of natural selection are at work, and in the case of the frog, something exists that determines the fact that, for this animal, carly spawning is the right thing. In a later chapter, it will be possible to show some of the advantages of being early. We can thus put the question as if it were a problem that the frog has to solve: given the necessity for carly spawning, how can the dangers of death from cold best be combated?

If a committee of engineers and physical chemists were to sit round a table to discuss the best material from which to make a heat-storage device, they would give much attention to water. No other material known to science has a greater specific heat, so that for any given quantity of heat added or subtracted, the temperature changes are a minimum. If, as is often the case, the object is to have a store of heat accumulated in one period, to be given out in another, then convection currents in the water are not a disadvantage, for both processes, heating and cooling, are equally desirable. If, however, the only object is to store heat, then the loss of heat in the cold parts of the cycle is a disadvantage. If only the water could be made solid, and if only the heat could be generated within the mass, the ideal material would be at hand. By producing the jelly, the frog has translated both these "ifs" into reality, with an efficiency not exceeded by any known material.

The jelly of the frog's egg has often attracted the attention of zoologists and chemists, each from their own particular point of view. The full story of this remarkable substance and its transformations can only be written by taking account of both points of view simultancously.

The fully swollen jelly contains only about I per cent of dry matter. This small quantity consists partly of salts from the water of the pond, and the protein, which provides the structure, only amounts to about 0.3 per cent. This is all the material that the parent frog needs to provide in order to produce an envelope weighing about 300 times as much, from the unlimited water of the pond, which provides the remaining $99 \cdot 7$ per cent. The jelly surrounds the vitellus, a small spherical black body, answering the physical idcal for the absorption of radiant energy. (The word "egg" is sometimes used by authors to refer to the black body alone, and sometimes to the complete object including the envelopes, and the context must be cxamined to sec which 
use is intended. In this book the word "egg" is kept for the whole object, and the black body is referred to as a "vitellus.") At least when the spawn is fresh, and in clear water for much of the time that it contains the embryos, the jelly is transparent, so that there is little hindrance to the heat and light from the sun which strike the vitellus and are there converted almost entirely into heat. Surrounded as it is by the relatively enormous mass of solidified water, this heat is not lost, but is absorbed with nearly the minimum possible rise of temperature. When the sun goes down, the process is not exactly reversed. The temperature of the mass has been raised, it is true, but it is still quite low, and so radiation is small. There are no convection currents, so that this cause of heat loss does not exist. Only conduction remains, but water is not a good conductor. There is therefore a tendency for the mass of eggs to remain during the night at a higher temperature than a similar mass of liquid water. This has been shown experimentally (Savage, 1950) for both eggs and for an artificial jelly, exposed to the light from an electric lamp and compared with a similar quantity of water in a similar vessel. The light was switched on and off at various intervals, and, for example, after a period of illumination in the evening, the eggs were $0.8^{\circ} \mathrm{C}$ warmer than the water next morning, although the light was left off all night. In the field, 73 measurements of the temperatures of egg clusters were made. In 63 cases, the eggs were warmer than the surrounding water, and in Io they were colder, but in 3 of them, there were exceptional conditions, such as shade or very freshly laid eggs. The mean temperature difference between the eggs and the water was $0.63^{\circ} \mathrm{C}$. This difference may not seem large, but in the following paragraphs, it will be shown that it may well be of considerable importance.

The frog population of the British Isles probably entered the country at a time when the islands were still joined to the Continent. If at any time since then, weather at the time of spawning had been of such exceptional severity that the thermal death limits had everywhere been exceeded, there would probably be no frogs in the islands today. If, on the other hand, even one pond existed where the temperature was just a little warmer, the whole country would in course of time become re-populated. Very small differences of temperature become important when the temperatures are near the critical limits.

So far, I have been considering the temperature of ponds, but of course just the same applies to masses of eggs; if the eggs at the warmest 
part of the warmest pond in a season with a fatally low temperature elsewhere were at even a slightly higher temperature, the species would survive. It is important to note that the time scale in this argument is a long one. The fact that in one lifetime, or even in recorded history, no such catastrophe has occurred to our knowledge is not quite the point. for in ten or twenty thousand years a very rare event may happen several times.

Dickerson (I906) considered that the jelly absorbed and held the warmth from the sun's rays, and provided a somewhat higher and more equable temperature than that of the surrounding water, and slic was undoubtedly right, although she gave no measurements to show that her opinion was based on fact.

Douglas (1948) for European frogs and Moore for the North American species (I939) as well as for $R$. temporaria (I95I) have studicd the relation between the highest temperature that the eggs can withstanc without any abnormal development occurring, and the geographical distribution of the species. They conclude from laboratory experiments that those species that breed early in the year and have compact masses of spawn, among them $R$. temporaria, are unable to survive temperatures as high as those species that breed later and lay their eggs in films or small bunches of spawn are able to do, and they think that the southern limits of the species may well be set by these biochemical limitations. Balcells (I956), in a study of $R$. temporaria on the Spanish side of the Pyrenees, where, as mentioned already, this frog occurs in isolation, concludes that the July isotherm of $2 \mathrm{I}^{\circ} \mathrm{C}$ is the southern limit. Douglas gives figures to show that the eggs of this species do not survive long above $24^{\circ}-25^{\circ} \mathrm{C}$ in close agreement with Moore's estimate of $25^{\circ} \mathrm{C}$. On the other hand, the more southern species, $R$. esculenta, survives about $28^{\circ} \mathrm{C}$. Moore provides similar data for the American species, but in a later paper (I940) suggests that the lethal effects of these high temperatures may be due to the high rate of metabolism produced by these high temperatures, which in turn so increases the demand for oxygen that the embryos are unable to get enough through the compact masses of jelly. It scems, however, that although he may be quite right in attributing to temperature the failure of those species with compact masses of spawn to colonize the southern regions, and $\mathrm{cvcn}$ right in thinking that there may be difficulties in gascous diffusion, the assumption that the gases have to diffuse through five to ten centimetres of jelly is probably not correct when the eggs are in their native 
ponds, as will be seen from the following account of the jelly mass in $R$. temporaria (Savage, I950).

The jelly mass is not an amorphous lump, in which are embedded the vitelli. On the contrary, it possesses a structure, which may be likened to a bunch of grapes glued together only where they touch, and having wide channels (the intercapsular channels) between each egg. Indian ink dropped on a freely floating cluster falls right through in a very short time, and small swimming animals can be seen under the microscope to emerge from the depths. The diffusion of gases so essential for respiration does not therefore take place over distances of, say, five or ten centimetres but only over the semi-diameter of the envelope, a matter of a few millimetres. The structure cannot act like this unless the clump is floating or at least supported under water on some irregular surface, because the jelly is so weak that, if it has to support its own weight, it collapses and obliterates the channels. It is for this reason that large clumps of spawn brought into the laboratory often develop irregularly. The clumps are commonly placed in only enough water to cover them, in a dish with an impervious surface, and the lower ends of the channels are then blocked by the collapse of the mass. In the field, not only are the clumps laid in a greater depth of water, but there is almost always enough wind to disturb the water and produce a gentle oscillation of the clumps which produces a current of water through them.

Now, in all this discussion of the probable effect of the jelly mass and temperature on the distribution of frogs, there has been one feature missing-confirmation from the field. All laboratory experiments that are performed, not for the intrinsic interest of the facts discovered, but for the light they may throw on ecology, must satisfy the requirement that besides being valid, they must also be relevant. This point comes up over and over again in ecology, so that it may be as well to make it clear now what is meant by this distinction. An experiment is valid if it is competently performed and correctly analysed so that it is clearly significant, whether or not a statistical test is actually applied. It is, however, only evidence of what happened in the experiment, and this remains true even though it is successfully repeated many times by many people. The conclusions drawn from the experiment can only be transferred to other conditions by a process of inference that corresponds to the graphical process of extrapolation. It is well known that the extrapolation of even a straight line far beyond the 
points on which it is based is a risky procedure. If the line is curved or has some complicated shape, then extrapolation is quite unjustified, for no one knows what twists and turns the line really takes beyond the points that have been determined. Mathematics can often help to decide the validity of experiments or observations, but is of no use in deciding relevance, a matter that depends on the exercise of judgment in the light of all available facts. Great caution is therefore always needed before accepting that the results of experimental zoology or physiology really apply to ecology, for however important they may be in themselves, as additions to scientific knowledge, they may be quite irrelevant to ecology, if they are merely accurate descriptions of events that never happen in nature. The test of relevance is to try and find something in the field that corroborates the laboratory results. It need not be as extensive evidence as that provided in the laboratory but the two sets of observations must fit. If there is no fit, then the laboratory results are not applicable to the field. It is never the other way round, for, provided a field observation is correctly reported, and is therefore valid, it must be relevant, for no process of extrapolation is involved-it is direct evidence. These remarks are inserted here not because they apply especially to the work of the authors who have studied this special subject, but simply because this is Chapter I, and a suitable place to emphasize a general principle.

To return now to the effect of lethal temperatures on distribution, no one seems to have reported the death of eggs and embryos in the field under circumstances that could be attributed to high temperatures. Dickerson (1906) stated that in Texas, tadpoles and water frogs are often killed in large numbers in the shallow pools, and considered that death occurs at $40^{\circ} \mathrm{C}$. This is not quite the evidence that is being sought, but it shows the kind of thing that is wanted. For $R$. temporaria there is a little evidence, not enough to establish the case, but at least suggestive. The spring of 1949 was exceptionally warm in south-castern England, and in a pond on the borders of Middlesex and Hertfordshire, some spawn reached a temperature of $2 \mathrm{I} \cdot \mathrm{S}^{\circ} \mathrm{C}$. This is perilously near Douglas's figure of $24^{\circ} \mathrm{C}$, or Moore's of $25^{\circ} \mathrm{C}$, but not quite there. The spawn in two other ponds in the same area on the same day did not nearly reach this temperature, but was in each case at about $15^{\circ} \mathrm{C}$. When values show a range as wide as this, it often indicates that even the extreme value actually observed would be exceeded if more observations had been available, and it is rather likely that somewhere 
in England on that day, spawn was in danger from the heat. England is a long way north of the southern limits of distribution, and it is even more likely that somewhere in Europe, some spawn was killed. A spring like that may not happen again in England for a long time (three weeks later, the hot weather continued, and the tadpoles in this pond were in water at $29^{\circ} \mathrm{C}$ ), and the best chance of verifying the hypothesis of Moore and Douglas would be at the southern limits of the species. Even a few cases of heat death in eggs laid naturally in a pond would be of much interest.

There is, however, another more complicated effect of high temperatures at spawning time. If spawning is delayed for any reason, the eggs within the frog may become over-ripe and develop abnormally, or even die altogether. Nussbaum (1897) considered that under these conditions $R$. esculenta absorbs the eggs without laying them, but that $R$. temporaria under the same circumstances lays infertile eggs. Witschi (I952) has pointed out that spoiled eggs of this species are rarely found in the field, and I agree with him. He made a detailed study of the abnormalities that can be produced by delayed spawning. He found that over-ripe eggs are much more sensitive to the deleterious effects of high temperatures than those that have only been in the ovisacs for a few days. If they remain there for a week at $20^{\circ} \mathrm{C}$, they die. Now, delayed spawning can be produced by several conditions, but hot weather at spawning time is one of them. It is therefore possible that at the southern limits of the species, spawning will sometimes be delayed by the hot weather, and that many of the eggs will as a result be infertile. Moreover, the delay itself makes it more likely that, as the season advances, lethally hot weather may kill those eggs that are alive when laid, so that the effects of Moore and Douglas become reinforced. I have seen events in the field that support this suggestion. In 1958 , spawning in my area was delayed. The cause of the delay was not in this case high temperature at spawning time, so that only the effect of the delay could be observed. In one pond, there were thirteen clumps of eggs. Of these, six contained spoiled eggs in an abnormally high proportion, and there was in addition a clump of jelly with no vitelli at all in it. It seems almost certain that here was a field instance of the effects that Nussbaum and Witschi have described, and that these frogs were breeding so late that they only just succeeded in doing so at all. Very few ponds contained spawn and the breeding population was much reduced. In 1960 this pond again had spawn later 
than other ponds, and of the seventeen clumps, seven had spoiled eggs in them.

It is, however, rather unusual in biology for a simple explanation such as this to account for the whole of the facts of a complicated matter like the geographical distribution of an animal. We do not, for example, know that this frog, regarded by taxonomists as one species, has the same thermal physiology in different parts of its range. Volpe (1953) has shown that, in the case of Bufo americamus, the eggs from toads coming from Oklahoma were less tolerant of cold than those of toads from Wisconsin or North Carolina. Volpe does not think that the upper lethal temperature, $3 \mathrm{I}^{\circ} \mathrm{C}$, is a limiting factor, because he doubts whether this temperature is reached in the breeding ponds, although he says that there are no temperature readings to confirm this view. It will be recalled that a temperature only two degrees less than this has been found in England, not a very hot country, and Dickerson's remarks suggest that in Texas, $40^{\circ} \mathrm{C}$ may be reached. Spallanzani in the eighteenth century (from Daudin, I802) was interested in this problem and put the thermal death point of the eggs of a species that was probably $R$. esculenta as high as $35^{\circ} \mathrm{R}$, approximately $43^{\circ} \mathrm{C}$, and has an account, given him by a friend, of living frogs in the Baths of Pisa in a temperature of $37^{\circ} \mathrm{R}\left(46^{\circ} \mathrm{C}\right)$. Zoologists in the eighteenth century made many excellent field observations and these results differ by only $\mathrm{I}^{\circ}-2^{\circ} \mathrm{C}$ from observations of Seurat (1922), who found $R$. esculenta and its tadpoles in a hot spring in North Africa at $44^{\circ}-45^{\circ} \mathrm{C}$. For all we know at present, the eggs of $R$. temporaria from the extreme southern parts of its range may withstand higher temperatures than those of the frogs used by Douglas, taken in the neighbourhood of London, or those of Moore, from north-east France and Belgium. A slight change of habit, such as a tendency to lay eggs in the shade, rather than in full sun as is usual in England, could extend the range by hundreds of miles.

It is much easier to say that field observations are needed to settle this question than it is to provide them. By definition, the observations would have to be carried out at the southern limits of the range, and it is almost certain that there, the frogs would be rare. Local knowledge would be necessary to find the breeding ponds of the rare animal, and only in some seasons could it be expected that climatic conditions would be suitable. It is the sort of work that only residents in the areas would be likely to carry out successfully. All they would need, 
however, would be a thermometer, a notebook and a pencil, and the ability to recognize dead eggs, a very easy matter.

Up to this point, the narrative has depended on work most of which has already been published. This extraordinary material, the jelly of the egg, has still some further surprises to yield up, and in the following paragraphs I give an account of some observations not yet complete in some of the biochemical and physiological aspects, but sufficiently so to form a part of this ecological story.

\section{Biochemical Properties of the Jelly}

By a coincidence, Dr. Burgess Barnett and I shared a common interest in two unrelated scientific fields-the study of amphibia and of blood-clotting. In May 1939, Dr. Barnett, who had just left the Zoological Society of London, where he had been the Curator of Reptiles, for a similar post at Rangoon, wrote to say that he had "stumbled upon" a curious property of the frog's egg. The jelly contained a clotting factor which he likened to the prothrombin of blood. He invited me to collaborate in its investigation, and when I accepted he sent me the only notes that he had. They consisted of some tests on normal and on haemophilic blood. In I939, the subject of blood-coagulation, although it already had a large literature, had not grown to the enormous extent that it has now assumed, and in the light of more recent knowledge, it is clear that the factor he had discovered was not prothrombin, but a variety of thromboplastin. Thromboplastins are rather widely distributed in nature, sometimes occurring in unexpected places, and if this had been the only point, there would have been only a mild interest in the fact. From Dr. Barnett's letters it seems clear that he had not any idea of the possible function of the factor, and very tentatively he suggested that it might be protective. He was perhaps led to this view from his recent studies, with Dr. R. G. Macfarlane (I934), on the clotting properties of the venom of the Russell viper, which kills its prey by injecting a variety of thromboplastin. Before we reached the point of actually collaborating, Dr. Barnett died. There the matter remained, until in planning this chapter I realized the probable function of the factor and the part it may play in the ecology of the frog and very likely in the lives of other species as well.

It is necessary at this stage to explain very briefly the function of these factors in the coagulation of the blood, for there is now little 
doubt that some of the properties of a part of the jelly of the egg depend on analogous reactions.

When the blood is circulating normally in the vessels, it does not clot. As soon as the blood escapes and comes into contact with a surface such as damaged tissues or a glass vessel, an extremcly complicated serics of reactions begins, in the course of which various factors appear and play their brief part. Among these is thromboplastin. This factor, in the presence of the calcium ions always present, acts on a protein, prothrombin, to produce thrombin, an enzyme. The plasma also contains a soluble protein, fibrinogen, present to the extent of about 0.3 per cent. Thrombin converts fibrinogen to fibrin, which is insoluble and exists in the form of threads. These threads ramify through the blood and form the skeleton of the clot, in the interstices of which the rest of the blood is entangled. The "problem" that is solved by these reactions is this: the blood is required to remain fluid indefinitely while it is in the vessels, but must become solid, with as little expenditure of material as possible, as soon as it is shed. The "problem" that the frog has to solve is this: the jelly envelope must originate as a liquid, for only a liquid can be secreted by the tubular glands of the oviduct. It must become solid with as little expenditure of material as possible. When it was realized that the percentage of protein in both the structural part of a blood clot and in the jelly of the frog's egg is the same, and that both contain a clotting factor, it became obvious that the parallelisms were too close to be merely a coincidence.

When the frog ovulates, the vitelli leave the ovaries and pass down the oviducts to the dilated portions of these organs known as the ovisacs. There they wait until the moment of oviposition, which takes only a few seconds. The mass of eggs, measuring about 20 to $30 \mathrm{ml}$, passes through the narrow cloacal opening in this time as if it were a liquid stream. A few seconds later, the eggs become solid and swell, eventually becoming a mass some three hundred times the bulk of the ovisac eggs.

Dr. Barnett used eggs laid naturally. Since he also reported the existence of a similar clotting factor in the skin of frogs, it secmed necessary to discover whether the ovisac eggs contained the factor, for it was possible that the egg factor might be merely a contaminant. Dr. J. F. D. Frazer was kind enough to provide a number of frogs that had been used a few hours before for some physiological experiments 
not involving the ovisacs. In the first year, most of these frogs had ovulated, but had not laid their eggs. In the second, none had ovulated.

The eggs found in the ponds have two envelopes. The ovisac eggs have only one, a firm layer of jelly about $0.3 \mathrm{~mm}$ thick. These eggs are, however, embedded in a viscous protein solution, and can move freely and separately in this liquid. If these eggs, with the adhering liquid, are put into water, they immediately stick together and also to any surface that they touch, just as they do when they are laid naturally. Swammerdam, writing in the seventeenth century was probably the first to note this sequence of events, when he wrote, "But as the eggs rendered very clammy and glutinous by the white that invested them have grown together, had been compressed in the uterus, they immediately on being cast into the water, expand themselves into their former round form!" (Eighteenth century translation.)

The ovisac eggs begin to swell at once, and in a few hours resemble in every way the naturally laid eggs, including the two layers of jelly. If, however, the eggs are taken from the ovisacs and put into normal saline, they do not adhere to each other, nor to other surfaces. In fact, an egg can then be rotated in contact with another with unusually little friction. They remain separate indefinitely, and thus resemble those of Discoglossus pictus. The eggs put into saline swell just as they would have done in water (but more slowly), and have only one layer of jelly. If they are thoroughly washed in saline, they do not adhere at once when put into water, but in time they may do so imperfectly.

It is now obvious that the two layers of jelly are composed of two quite different proteins. The inner is a gel, even within the frog. The outer is a sol that becomes a gel instantly when it comes into contact with water, but not when the water is replaced by saline. These are the properties of the class of proteins known as globulins, and the formation of the outer envelope seems to depend on nothing more than the precipitation of the globulin when the salt that kept it in solution has been removed by the water of the pond. It is an ordinary chemical reaction, and is practically instantaneous. The saline solution of this protein contains no clotting factor, but a saline extract of the inner envelope contains a factor that behaves just as that reported by Dr. Barnett. The activity of these extracts is quite small, but that is not surprising, when it is considered that most clotting factors are unstable and disappear soon after they have done their work, and that the 
substrate used for testing was not that natural to the system. It seems almost certain that all that was found was the remains of a powerful clotting system, functioning within the oviduct. The probable course of formation of the inner envelope is this: the secretion of the oviduct is clotted by the action of this factor, and the vitelli, as they pass down the duct, act as nuclei for the deposition of the clot, and thus become invested by a spherical shell of jelly. Rugh (1935) has found that lead shot will become coated with jelly if it is introduced into the oviduct. This view is also supported by the observation that, in all the frogs examined, the ovisac eggs included some spheres with no vitelli inside them. These spheres were in other respects just the same, and swelled in the same way. The clotting factor does not come from the vitelli, and this conclusion was made certain by the examination of the clump of jelly mentioned above as having no vitelli in it. It contained the clotting factor.

In the second season, when none of the frogs had ovulated, an attempt was made to find the source of the factor. The coelomic fluid was inactive, and so was a saline extract of fincly divided oviduct and ovary. The resemblance to blood-clotting became even closer, for just as blood thromboplastin appears as if by magic just when it is wanted, so does the clotting factor for the egg-jelly. The analogy must, however, not be pushed too far, for the biochemistry is probably quite different in many ways. This is a biochemical problem that may remain obscure for a very long time. It may be as complicated as blood-clotting, and the scientific effort required for its solution is never likely, in the foreseeable future, to approach that devoted to haematology. All that I have done is to lift a little higher a comer of the curtain against which Dr. Barnett "stumbled."

Ovisac eggs swell even in Io per cent saline and 30 per cent urea, solutions with osmotic pressures far above that of frog plasma. The swelling is undoubtedly due to the imbibition of water by a fairly concentrated protein gel, a process that has nothing to do with osmotic pressures. A puzzle that still remains is this: why do the eggs not swell while they are inside the frog? Actually, they do swell sometimes, and Nussbaum (I897) says that if oviposition is delayed the frogs may die. It is possible that the reason this does not usually happen is simply that there is not often time for the absorption of enough water to be dangerous. Oviposition usually takes place at most a few days after ovulation, and the eggs form such a large proportion of the weight 
of the frog that, even though the frog takes up water from the pond quite readily through its skin, there may not be enough time for the water to pass into the frog, then into the blood circulating in the walls of the oviduct, and thence into the eggs. The forces involved in the imbibition of water by proteins are very large, and there is no doubt that, if considerable water did gain access to the eggs, the results would be as disastrous as Nussbaum found.

This rather complicated story of the formation of the jelly envelope may, then, be summarized as follows. The vitelli pass into the oviduct. There they form the nuclei round which collects the insoluble product of a clotting system, in which a factor resembling the thromboplastin of blood contributes to a transformation that has something in common with the similar transformation that occurs when blood clots. The protein is not the same, and the rest of the process probably differs considerably. This protein layer is fairly concentrated. When it has formed, the eggs pass into the ovisac, where they become distributed in a fairly concentrated solution of a different protein. When they are ejected by the frog, the mass passes into water, salt is removed and the protein precipitates, forming the second and outer layer of jelly. Both layers now imbibe water, and in twenty-four hours or so achieve maximum size. In this process, the outer layer is stretched by the swelling of the inner layer, and gives way except at the points of contact of the spheres, where there is no stress. The final result is that a mass of adherent spheres is formed, with channels in between. The final percentage of structural protein in a blood-clot and in frog-jelly is about the same, but the clot and the jelly approach this concentration from opposite directions: the jelly swells, but the blood-clot is formed full size at once and, indeed, tends to shrink.

\section{Ecological Properties of the Jelly}

In some species, for example Rana sylvatica or $R$. aurora aurora, the envelope contains algae, as described by Dickerson (1906) and by Wright and Wright (1949) respectively, and Dickerson suggested that the algae may provide oxygen for the embryos. Occasionally, the eggs of $R$. temporaria are green, although this seems usually to be due to algae on the outside, but it is easy to see that, if the outer layer of jelly, which is a precipitate, is formed in water green with algae, then algae will be enclosed when the jelly forms. It is interesting that in the American species the algae are so constantly present that they are 
regarded as almost a diagnostic character of the eggs of these species. This should be kept in mind when reading Chapter 8 .

The adhesive properties of the newly laid eggs is often of no apparent use to the animal. $R$. temporaria is usually a pond-frog and often lays its eggs on a muddy bottom. Sometimes, however, it lays in streams, and on at least three of these rather rare occasions I have found that the eggs were attached to a hard surface, in some cases to the concrete of bridge foundations or other artificial structures. In another, the eggs were firmly attached to a submerged weed mat in mid stream. In one of these cases, as will be described in Chapter 9, the whole breeding behaviour was modified so that actions normally taking place at the surface of the water occurred right at the bottom on the hard surface, and the eggs were fastencd there. In other species, this sort of thing is normal, but it is interesting to note the flexible bchaviour of this animal, which seems capable of adapting a whole chain of complicated reactions to circumstances that are quite unusual.

It is not only in streams that the frog may sometimes glue its eggs to something solid. I once found a single clump in a pond in an unusual place, under a bush in a deep part of the pond, although this pond had the shallow end that the frogs usually frequent. The clump was firmly attached to a twig of a bush that was a few centimetres under water. The frog must have sat on this twig when it laid its eggs. $R$. sylvatica is generally considered to be nearly related to $R$. temporaria, and, in a photograph of the eggs of this species, Wright and Wright (I949) show them apparently glued to twigs under water.

There are some frogs that lay their eggs out of water in nests that they construct from a foamy secretion. In the description of the construction of these nests, by species of Limnodymastes for example, it is stated that the animals beat the secretion with their tocs, sometimes with such rapid motions that the eye can scarcely follow the movements. In the preparation of fibrin foam, used in surgery, the clotting mixture is beaten by an electric stirrer. It is surely likely that these two procedures are essentially the same, both depending on beating air into a clotting mixture. This is another instance of the existence of the essential features of what appears to be most extraordinary bchaviour in one species in the biochemistry of a more normal species. The familiar $R$. temporaria possesses the essential physiology and biochemistry for making a foam nest, if it modified its behaviour in two ways. It would have to lay its eggs out of water, and it would have 
to develop an instinctive agitation of its toes. There would have to be other modifications, of course, but these foam nests do not seem quite so different from anything that normal species produce.

The jelly envelopes are so lacking in nutritive properties that there are few animals in the pond that will deliberately eat them. Moorhens (Gallinula chloropus) occasionally eat the eggs, and mince up the whole egg mass in order to reach the vitelli, leaving most of the jelly floating on the water. This behaviour of the birds seems to be erratic. In some years they will attack the eggs, but in others, even in the same pond, with both eggs and birds present, the eggs are left entirely alone.

It has usually been considered that the tadpoles feed on the envelopes after they hatch, but this is not so. The tadpoles grow considerably during the time that they remain on the envelopes, but this increase in size is solely due to an increase in the water content of the animals, which at this time are building up their bodies from the store of concentrated nutriment provided by the parent frog. This they do by forming tissues containing much more water than the yolk, and by constructing organs many of which are hollow, and so take up still more space. These conclusions were reached by measuring the dry weight, the nitrogen and the carbohydrate of the developing eggs and embryos of several species after hatching, and it was possible to show that, with some minor complications, there was a drop in all three properties until the little animals began to feed on the food particles in the pond, some of which, it is true, are on the surface of the envelopes (Savage, 1937, 1938). They grow as fast when they are removed from the envelopes. Moreover, there is a septum closing the mouth at this stage, so that the tadpole could swallow no food. This septum does not break until the tadpole is about to leave the neighbourhood of the envelopes. When it is also recalled how dilute this jelly is, these facts are not surprising, for even the water of the pond often contains as much nutriment, and an animal could get as much benefit by gulping down water as by eating the envelopes. Figs. 2 and 3 illustrate these experiments, and it can be seen that hatching is a mere incident in the life of the tadpoles. It probably occurs at a stage when the growing need for more oxygen and the means for eliminating carbon dioxide and other excretory products make it impossible for the young animal to remain any longer inside the jelly, but the newly hatched tadpole is in other respects just an embryo that has escaped from the envelope. 


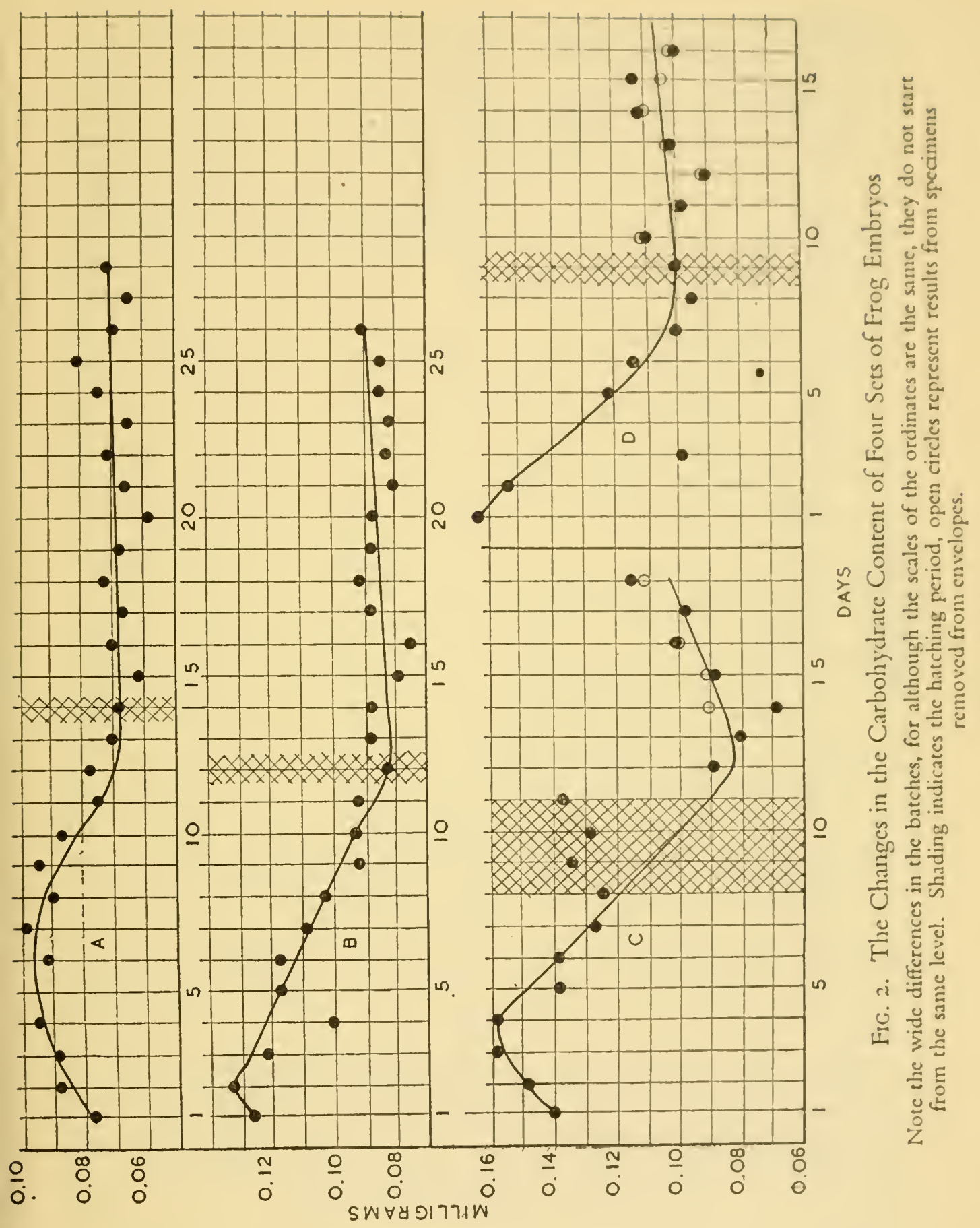




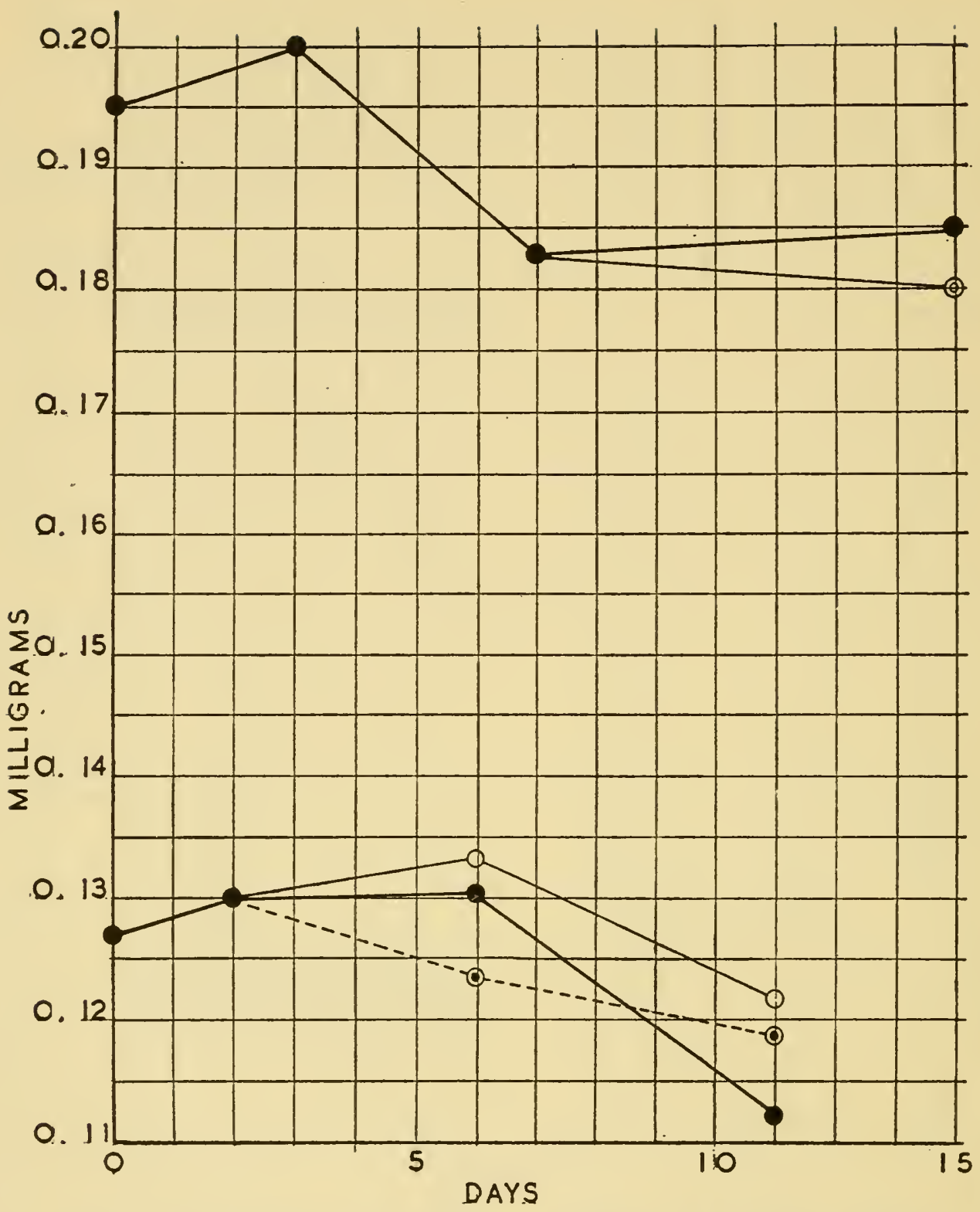

FIG. 3. The Changes in the Nitrogen Content of Two Sets of Frog Embryos, left on the Spawn after Hatching and Removed from it

Note that there is no appreciable difference. In fact, one set gained more when on the jelly, and the other gained less. Note also the large difference in the two sets of embryos. Black circles on spawn. Open circles, not on spawn. Black and open circle, near spawn. 


\section{Hatching}

In a short time after hatching, a new phase in the life of the tadpole begins, and the nutritional problems of the older tadpoles will be considered in the next chapter, but here it must be considered low the hatching process is effected, and how the colony of tadpoles above the discarded envelopes is formed and maintained in position.

It is practically certain that the hatching process is produced by the action of an enzyme that dissolves the jelly. This has, apparently, not been found for this species, but Bles (1906) found a hatching enzyme in Xenopus laevis, Noble (1926) in Alytes obstetricans and Cambar (1953) in $R$. dalmatina, and the process in $R$. temporaria seems to be similar. Because of the structure of the jelly mass, the tadpoles hatch into the intercapsular channels. The problems that now have to be solved are: how they reach the surface when they can hardly swim, and how, when they get there, they manage to get enough oxygen, and how it is that these enormous colonies do not become dispersed throughout the pond sooner than they do.

This phase in the life of the tadpoles does not last long. If the pond is visited during this period, and if there is a large number of clumps of spawn, it will usually be found that the young animals form a dense carpet of black bodies, just beneath the surface of the water and just above the disintegrating mass of envelopes that they have left. Sometimes, there are as many as half a million of them, and once I estimated that there were about five million in one continuous layer. Generally, the animals in these large aggregations are in a state of continuous movement but, if there are only a few clumps, this does not occur. The following experiments showed what was happening (Savage 1935).

Determinations of dissolved oxygen showed amounts of from 3 per cent to I6 per cent of saturation. Some experiments by Helff and Stubblefield (193I) showed that the tadpoles of $R$. pipiens cannot live in water with less than about I $8-22$ per cent of saturation and fishes have similar requirements. Tadpoles taken from these aggregations and put into the water from which they came died if the vessel was deep, but lived if it was shallow. The habit of aggregation carried with it the risk of death. By putting tadpoles of this age into an experimental vessel (Fig. 4) it was found that, although they were so young that they did not swim when they were stirred round in water, and stayed quite still in well-oxygenated water, they were capable of considerable swimming movements, enough to take them to the 
top of a shallow vessel, if they were stimulated by lack of oxygen. This shortage of oxygen was sometimes produced by merely allowing the tadpoles placed in the horizontal tube to exhaust that which was present at first, and sometimes by removing oxygen from the water artificially. When this was done, the little animals became restless, and swam upwards. If these movements took them into a betteroxygenated part of the vessel, they stopped swimming. This movement was therefore a combination of a kinesis (random movement

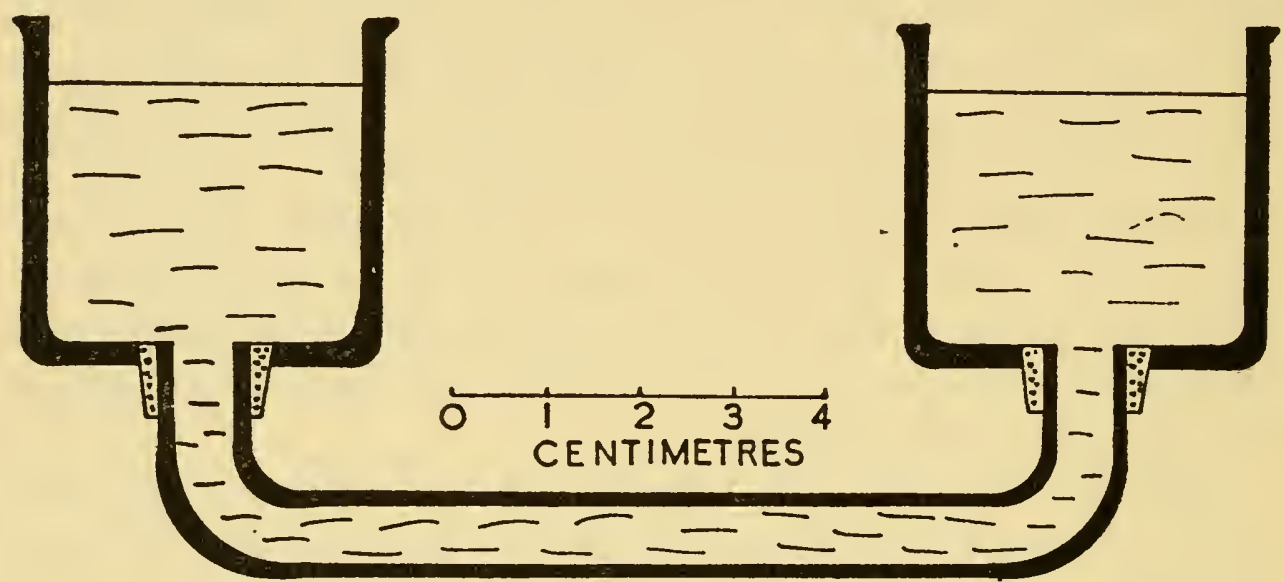

Fig. 4. The Apparatus Used for the Experiments on the Reactions of Young Tadpoles to Deficient Oxygen

under the influence of a stimulus) and a negative geotaxis (a movement upwards) when once movement was provoked by lack of oxygen.

Transferring the results of the experiments to the field, it is now possible to explain what happens. The tadpoles in the central parts of the large aggregations live in water with very little oxygen. They therefore swim upwards. Those at the edges of the aggregation are in better-oxygenated water, and, not being stimulated, do not swim at all. The colony therefore remains in the same place as a whole, but the individual members of it are continually changing places. When there are only a few clumps, there is enough oxygen for all, and no swimming takes place. All that is seen in such cases are the gymnastic exercises that tadpoles of this age execute while they hold on with the aid of the adhesive gland with which they are provided.

\section{The Function of the External Gills}

The water of these places has another unusual feature. It is full of the gelatinous remains of the envelopes, and during the determinations 
of dissolved oxygen (which must be done at the ponds) considerable difficulty was found in drawing up the water into the tubes of the apparatus, because of the blockage due to fragments of jelly. It could certainly not pass through narrow passages such as those that exist in the respiratory systems of the older tadpoles. It is just as this time that the feathery external gills of the tadpoles are at their maximum development. These are really rather puzzling structures. They develop soon after hatching, and not long afterwards disappear when they are overgrown by the development of the operculum, a fold of skin that grows from the anterior portion of the tadpole, and eventually encloses both the external gills and the new set of internal gills that serve the animal during the rest of its life. The external gills are then gradually absorbed. They therefore last for a very short time, and it is surely remarkable that this period should be just the one when the tadpoles are living among a glutinous mass of decomposing jelly. They could not use a respiratory device that required this soup to be pumped along channels, but they can use gills that only require to be waved in the water to pick up any oxygen that happens to be there. If now the natural aggregation is examined at this stage, just a little later than that at which it is first formed, it will be seen that the animals live very near to the surface film. They are in almost constant motion, vigorous enough for some tadpoles to be lifted almost out of the water by the efforts of those underneath. At other times, they reach the surface by their own efforts, and as soon as the external gills spread out as a feathery fan on the surface of the water, the tadpoles stop swimming and sink down to a lower level. The blocking of respiratory channels is a problem for all animals that live in water that is thick with sediments of any kind, and it will be shown in Chapter 3 that the full-grown tadpoles have another device for dealing with it, but in the stage now being considered it seems likely that in these feathery gills there is an instance of a special larval organ, developed for a few days to deal with a quite temporary environment. The events that have just been described are not usually to be seen at all in clumps of spawn brought indoors and put into a vessel of water. This is essentially a field phenomenon, and even there it is necessary to find a pond with plenty of spawn in it before its full development can be studied.

If it were possible to regard the ingestion of food through the mouth as the only way that the tadpoles could get any nourishment from the envelopes, it could at once be said that the envelopes have no 
nutritive function, because the mouth is still closed. However, Krizenecky and Podhradsky (1924) found that tadpoles were capable of absorbing dissolved substances through their skins, and in a review Krogh (I93 I) came to the conclusion that such absorption was rare in vertebrates but did occur in tadpoles. Since the envelopes are disintegrating at this stage by bacterial action, which might break down the mucoprotein to simpler and diffusible materials, it still seemed possible that there would be some nutriment for the tadpoles in the water. However, when a comparison was made between tadpoles left on the envelopes and those removed from them, it was found that there was no difference in the final concentration of carbohydrate in the two sets (Fig. 2), and it was concluded that the disintegrating envelopes have no nutritive function. They do, however, play a part in depleting the oxygen in the water of the aggregations, for the water among a quantity of disintegrating envelopes of an aggregation in a pond was found to contain 210,000 bacteria per $\mathrm{ml}$ but the water of the same pond, about two metres from the aggregation contained only about 4,800 , and other determinations have given similar results. Bacterial action of this kind always makes a heavy demand on the dissolved oxygen.

It now remains to consider what useful function is performed by this habit of aggregation. Of course, some advantage in temperature still remains, for not only is the carpet of tadpoles black and therefore a good absorber of solar radiation, but Gayda (I92I) has shown that small quantities of water in which toads' eggs were developing were as much as $1.5^{\circ} \mathrm{C}$ higher than the controls. Perhaps there is some protection from predators, for an environment deficient in oxygen would repel animals dependent on aquatic respiration.

In the aggregating habit, we may perhaps see another case in which the bizarre habits of an exotic frog could have been derived from one that had only those of our familiar $R$. temporaria. Some species, for example Hyla rosenbergii, build basins of mud at the edges of ponds, and inside these harbours, as Noble (1927) has described, the tadpoles live in a special environment produced for them by the parent frogs. The water is teeming with bacteria and deficient in oxygen, and the tadpoles have enormous pinnate gills that adhere to the surface film of the water. Our tadpoles do not quite achieve these extraordinary modifications, but the parent frogs, by laying all their eggs in contact with each other, help to create a special environment which the tadpoles continue to maintain and extend, so that ultimately an 
oxygen-deficient and highly polluted environment is produced. They even come within some distance of having the gill modifications of the more extraordinary animal, for they momentarily spread their gills in the surface film. The change in habit needed to convert one type of life history into the other seems to consist mainly in the building of the wall, for the anatomical, physiological and psychological modifications necessary for survival in a polluted environment are already present.

When the mouth opens, the tadpoles enter another phase of their lives, and this forms the subject of the next chapter.

\section{REFERENCES}

Balcells, E. (1956) P. Inst. Biol. Apl., 24, 8I-121.

Bles, E. J. (I906) Trans. roy. soc. Edin., 4I, 789-82I.

Cambar, R. (1953) C. R. Acad. Sci. Paris, 237, 4.355.

Dickerson, M. (1906) The Frog Book (New York).

Douglas, R. (1948) J. Anim. Ecol., 17, No. 2, I89-92

Fischer-Sigwart, H. (I 897) Vjschr. naturf. Ges. Zïrich, 238-3 I6.

GAYDA (I92I) Arch. Fisiol., III, 2 I I.

Helff, O. M. and Stubblefield, K. J. (I93I) Physiol. Zool., 4, 27I-86.

Krizenecky, J. and Podhradsky, J. (I924) Pflüg. Arch. ges. Physiol., 204, 47I-6.

Krogh, A. (I93I) Biol. Rev., 6, 4I2-42.

Macfarlane, R. G. and Barnett, B. (1934) Lancet, 2, 985.

Moore, J. A. (I939) Ecology, 20, 4, 459-78.

Moore, J. A. (I940) Amer. Nat., 74, 89-93.

Moore, J. A. (I95I) Proc. Nat. Acad. Sci., 37, 862-6.

Noble, G. K. (1926) Amer. Mus. Novit., No. 229, I-7.

Noble, G. K. (I927) Ann. N.Y. Acad. Sci., 30, 3 I-I28.

Nussbaum, M. (I897) Arch. mikr. Anat., 46, 479-500, 48, 545-50)

Rugh, R. (1935) J. Exp. Zool., 71, I49-63.

Savage, R. M. (I935) Proc. zool. Soc. Lond., 3, 605-1o.

SAvage, R. M. (I937) Proc. zool. Soc. Lond., A, 3, 249-60.

Savage, R. M. (1938) Proc. zool. Soc. Lond., A, 108, 465-80.

SAvage, R. M. (I950) Brit. J. Herpet., I, No. 3, 57-66.

Seurat (1922) Bull. Soc. Nat. Algérie, 13, 45-60, 77-92, I09-I40 (not seen).

Spallanzani, L. Reference from Daudin, Histoire naturelle des Reptiles, An., I3,

No. I, 233 (Dufart, Paris, ?1802).

SwAmmerdam, J. The Generation of Frogs (English translation by Hill, 1758).

Volpe, E. P. (I953) Physiol. zool., 26, 344-54.

Wrtschi, E. (I952) Cancer Res., I2, No. II, 763-86.

Wright, A. and WRIGHT, A. A. (I949) Handbook of the Frogs and Toads of the

United States and Canada (Comstock Publ. Co., Ithaca, N.Y.). 


\section{Chapter 2}

\section{THE GENERAL LIFE HISTORY OF THE TADPOLES}

IN the Amphibia, as well as in other groups of animals, it often seems that the larvae receive less attention than the adults. This is curious, not only because larvae have a considerable interest in themselves, but because, in the study of the whole life history of an animal, it is often the larval stage that throws much light on features of the ecology that would otherwise remain incomprehensible.

In attempting to review the literature (Savage, I952), I found nothing on the tadpoles of $R$. temporaria beyond the elementary facts contained in natural history books, and not much on other species except brief notes which, although interesting, made no attempt to cover more than some isolated phase of the life. All the references on tadpoles for this and later chapters are therefore of this rather minor character. Here, the tadpoles are treated not as temporary animals in the process of becoming something else, but as animals whose life, although short compared with that of the adults, is lived on an entirely different plane, and has called for special larval organs, habits and responses, to be considered just as if the adult frog had never been discovered.

In the last chapter, the narrative continued until the stage at which the tadpoles began to feed. Their behaviour after this time differs in different ponds and on different occasions. An adequate picture of the instability of life in a pond, and of the ups and downs of tadpole life, cannot be gained by compressing the events into one colourless summary. The risks, the successes, the disasters overtaking whole populations are fundamental to the ecology of the animal, and for their understanding detailed descriptions of specific instances are essential.

The methods adopted for the investigation were very simple. As many ponds as could be studied in the time available were visited at approximately weekly intervals, the tadpoles observed at liberty, and a sample collected and preserved for future study. Each tadpole was then weighed, some were dissected and the contents of the gut examined microscopically. The variety of events in tadpole ponds is so great that I hesitate to pick on one and label it as "normal," but it has seemed 
that tadpole life in Dagger Lane Pond pursues a more placid course than in some of the other ponds, and may serve as a background to the more dramatic episodes that have been seen elscwhere.

\section{Dagger Lane Pond}

(a) 1947 (Fig. 5). The winter of 1947 was severe and long, and it was followed by floods that left the ponds full of water at the begiming of

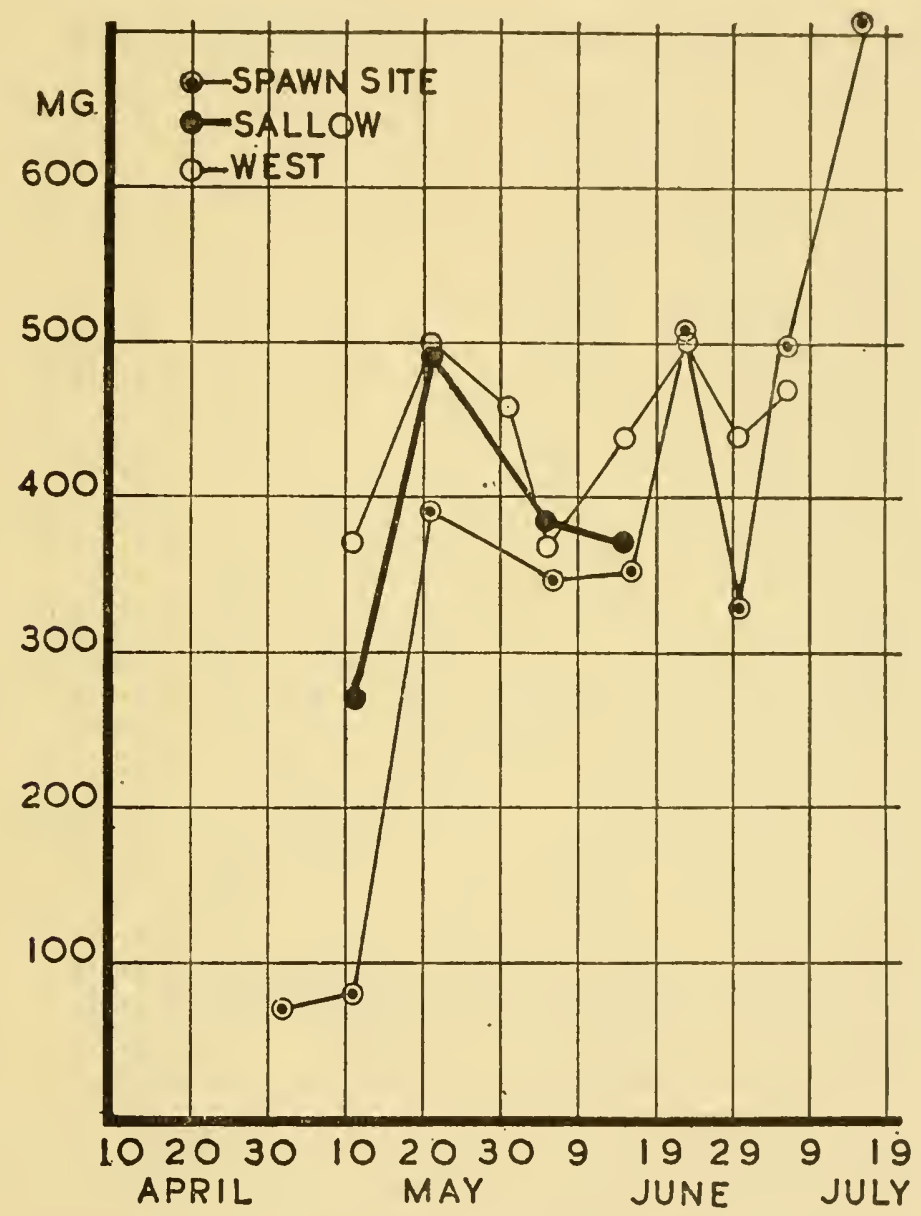

Fig. 5. Dagger Lane Pond, I947

The growth of tadpoles at three different places in the pond. Note that growth almost ceased between 2Ist May and the end of June.

the spawning season. About fifty clumps of spawn were laid in the pond just before 6th April. They had been deposited on the top of a floating patch of Starwort (Callitriche), a position which frogs sometimes prefer to the more usual places, the shallow margins of the pond. 
The vegetation was abundant, and besides the patches of starwort, there were floating patches of algae in many places. The water was clear.

When the pond was next visited on 2oth April, no tadpoles could be seen anywhere, and numerous sweeps of the net failed to collect even one. On 26th April, however, tadpoles had returned to the spawn site in large numbers, and were forming a dense and very active aggregation. Not many were seen anywhere else. On 3 rd May, the general behaviour was similar, but the dense aggregation had moved about $2 \mathrm{~m}$ further east. Many sweeps with the net were made at the west end, without result. On IIth May, no tadpoles could be seen at the places where they had been so abundant and only a few could be collected in the net. The west end now for the first time contained a dense aggregation, both among the starwort and also among some decayed rushes on the north bank, at the collecting spot known as "Sallow." One sweep brought up many hundreds of tadpoles. From Fig. $S$ it can be seen that the weights of the tadpoles collected from different places differed considerably. On 2 Ist May, large numbers of tadpoles had returned to "Spawn Site" (about $\mathrm{I} 2$ per $100 \mathrm{~cm}^{2}$ ), and some were seen elsewhere in the pond. There were now definite signs that the tadpoles were dispersing-there were colonies, widely separated from each other, with the intervening spaces free from the animals. Within each colony, the population was dense-in one case, there were as many as IOO per $100 \mathrm{~cm}^{2}$, and the pond was conspicuously crowded with tadpoles. At the next visit, on Ist June, it was at once obvious that a change had occurred. Although many tadpoles were to be seen almost all over the pond, there were no dense, heaving masses of them, but, on the contrary, each tadpole was leading a solitary life, with few, if any, signs of vigorous feeding movements. On 7 th June, some of the animals had metamorphosed, little frogs being seen in the neighbouring ditch as well as in the pond itself. There were, however, still some tadpoles left in the pond, and, on I6th June, the patches of algae which had disappeared began to reappear. Reference to Fig. 5 shows that the mean weight of the tadpoles did not increase from 2Ist May to 29th June, but that after this date there was a sharp increase. The final tadpoles collected were much larger than those that had metamorphosed weeks before, although there were very few of them. On Ist August, no tadpoles could be found.

The weather during the season was hot and dry almost all the time, with one wet spell in May. The level of the water fell, except during 
this spell, all through the season. The spawn site dried on $23 \mathrm{rd}$ June, although there was always enough water for the tadpoles in the rest of the pond.

(b) 1948 (Fig. 6). This season was noteworthy as much for its contrasts as for its resemblances to 1947. The winter had been mild

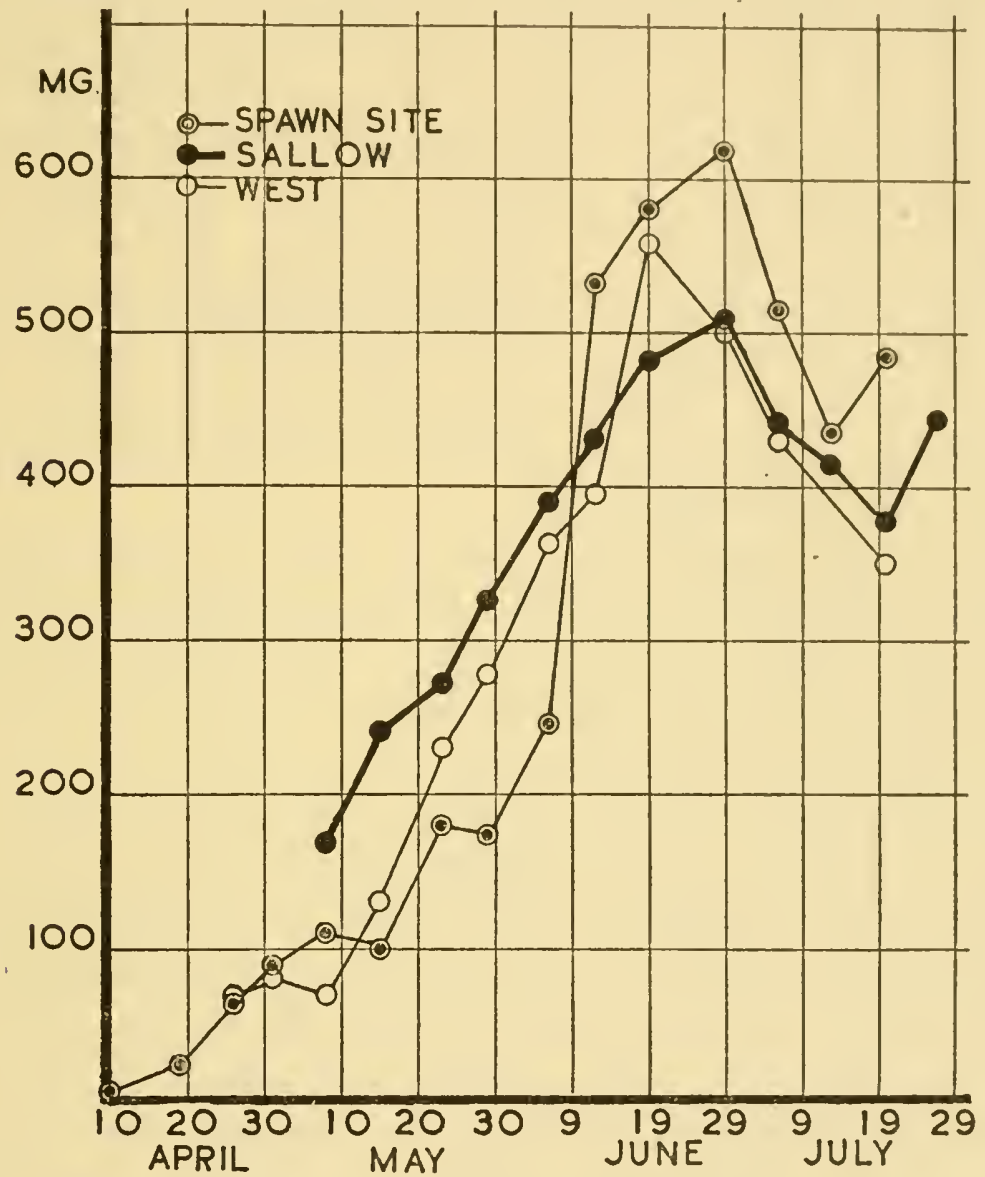

FIG. 6. Dagger Lane Pond, 1948

Note in this year the fairly steady rise in weights until the later half of June. In this and the other graphs, some of the drop at the end of the season is due to the inclusion in the sample of metamorphosing tadpoles.

and dry, and the season opened with the water level below normal. In May, however, the weather changed and the rest of the season was cool and rather wet. This is almost the reverse of the conditions in I947.

The pond looked entirely different. There were no patches of starwort, no visible algae, and the water was turbid and brown. Later in the season, many rushes grew from the bed of the pond to form a 
dense stand, an event never known before in the many years of observation of this pond.

Spawning was much earlier than in 1947. The number of clumps was not much different, perhaps slightly fewer, and they were laid in the shallows about $\mathrm{I}-2 \mathrm{~m}$ away from the place where the floating weed had been in the previous year. Hatching was in progress on $3 \mathrm{rd}$ April, and there was an aggregation on the envelopes until roth April. During the whole of the rest of the season, no dense aggregation was seen anywhere in the pond. It was estimated that the tadpole population was only about I per cent of that in I947. Reference to Fig. 6 shows that the growth rate was at first very slow. On Ist May, there were still no obvious patches of algae, and the tadpoles were feeding on the bottom of the pond. On 8th May, however, a patch of algae was seen at "Sallow," and the net brought up many tadpoles. Fig. 6 shows how much heavier these tadpoles were than those caught only about $5 \mathrm{~m}$ away at "West."

On Isth May, no tadpoles could be seen at "Spawn Site" but some were collected in the net. This also happened at "West." Tadpoles were still numerous at "Sallow," but the algae were turning brown, and had not appreciably extended in area, and no more were seen anywhere else in the pond.

Reference to Fig. 6 shows that from 8th May to 7 th June, the tadpoles at "Sallow" were always heavier than at any of the other collecting points, although after Isth May, the lead they possessed was progressively reduced. On 23rd May, the algae were quite brown and microscopic examination showed that this was due to the formation of resting-stages. The collections on 29th May and on 6th June showed nothing remarkable, but on 6th June it was noted that there were still no signs of algae at "West." The wet weather had now begun, and on $\mathrm{r} 2 \mathrm{th}$ June there was a sudden change. The water level was now so high that the marshy ends were covered with water. It can be seen from Fig. 6 that a corresponding change had occurred in the tadpole population. "Spawn Site" tadpoles were now the largest in the pond, and at the next collection on Igth June they retained this lead. The "Sallow" tadpoles were now the lightest. In spite of the earlier start to the season, metamorphosis had not yet begun-by this date in 1947 many of the little frogs had left the pond. On 28th June, the algae had disappeared from "Sallow." Metamorphosed frogs were seen at the next visit on 6th July, and the population of tadpoles was 
rapidly diminishing. On I3th July, no tadpoles could be found at "West" but some were still present at "Sallow" and "Spawn Site." On I9th and 27th July, only a few tadpoles could be found. By this time the water level had sunk again, the spawn site was dry and the water at "West" was confined to a few isolated pools.

(c) I949 (Fig. 7). The winter was mild and the rainfall about normal.

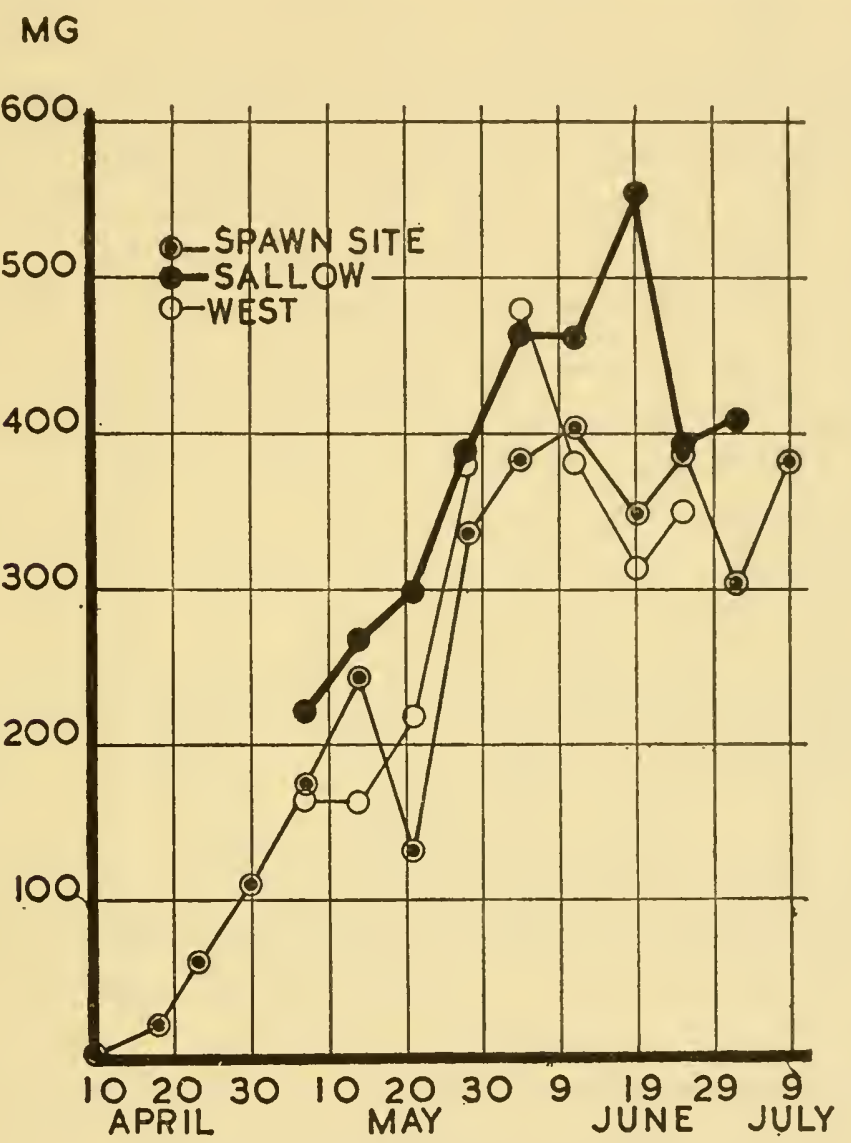

FIg. 7. Dagger Lane Pond, I949

A similar picture to that of 1948 , but metamorphosis was earlier. The contrast in size between the "West" and the "Sallow" tadpoles on Igth June should be noted. These two sites were only about $2 \mathrm{~m}$ apart.

Ponds were generally full. The season opened with exceptionally hot weather and, apart from some rain in May, it was very hot and dry throughout. Except for the winter, therefore, the season resembled I947 rather than 1948. The appearance of the pond and its vegetation also resembled that of 1947. The patches of starwort were there-in fact large areas of the pond were completely covered-the rushes had 
gone and did not reappear and the water was clear. There were, however, no prominent patches of algae, except at "Sallow." The quantity of spawn, laid on the shallow edge of the pond in about the same place as in I948, was about the same. It was hatching on Ioth April. On 23rd April, the aggregation on the envelopes was still present, but had spread over a larger area. No tadpoles could be collected at "West or "Sallow" on either this date or on $30 t h$ April. On 7th May, there was a dense colony at "Spawn Site." The tadpoles were feeding actively on the bottom, occasionally visiting the surface for air but diving at once. A small colony was found at "Sallow" and another at "West," but few were seen elsewhere. Fig. 7 shows that the "Sallow" colony was for the third year in succession the heaviest at about this date. By I 3 th May, the difference in the average weight of the tadpoles in the various colonies was even greater, and once again "West," although so near to "Sallow," contained much smaller tadpoles. On 2 Ist May, tadpoles were fairly numerous at "Spawn Site," but the figure shows how small they were-in fact lighter than in the week before. The wet spell then began, and by the 28 th the water level had risen. The average weight of the tadpoles at "Spawn Site" was now much greater than on 2 Ist May, and was little below that at "Sallow." On 4th June, the pond was full of water. "West" now provided tadpoles a little larger than "Sallow," and those in the colony at "Spawn Site" were not much smaller. Hot, dry weather now began again. The tadpoles at "Spawn Site" remained at about the same weight, those at "West" actually diminished, but those at "Sallow" continued to grow. By Igth June, the water level was low again. On 25th June, metamorphosis had begun, and from this date onwards collections could not be made at the usual places because there was not enough water there. On gth and I6th July, the borders of the pond were exposed and evil-smelling, and the water itself was foul. Most of the tadpoles had, however, metamorphosed by this time.

The tadpole population was larger than in 1948, but very much smaller than in 1947. There were some indications of colony formation in the early part of the season, but the struggling masses of 1947 were never observed.

Metamorphosis in Dagger Lane Pond was always complete by the end of July, and on the whole the tadpoles grew well. The disasters that occurred in some of the other ponds were never seen to the same extent at Dagger Lane. 


\section{Lower Parkfield Pond}

(a) 1947 (Fig. 8). This pond is almost circular, and about $21 \mathrm{~m}$ in diameter. In some places it shelves to the edges, but it is an ormamental pond in a public park and artificial rocks have been placed round parts of it, and there is a stone wall on one side. It is almost surrounded by tall trees that greatly affect the ecological conditions. There is little

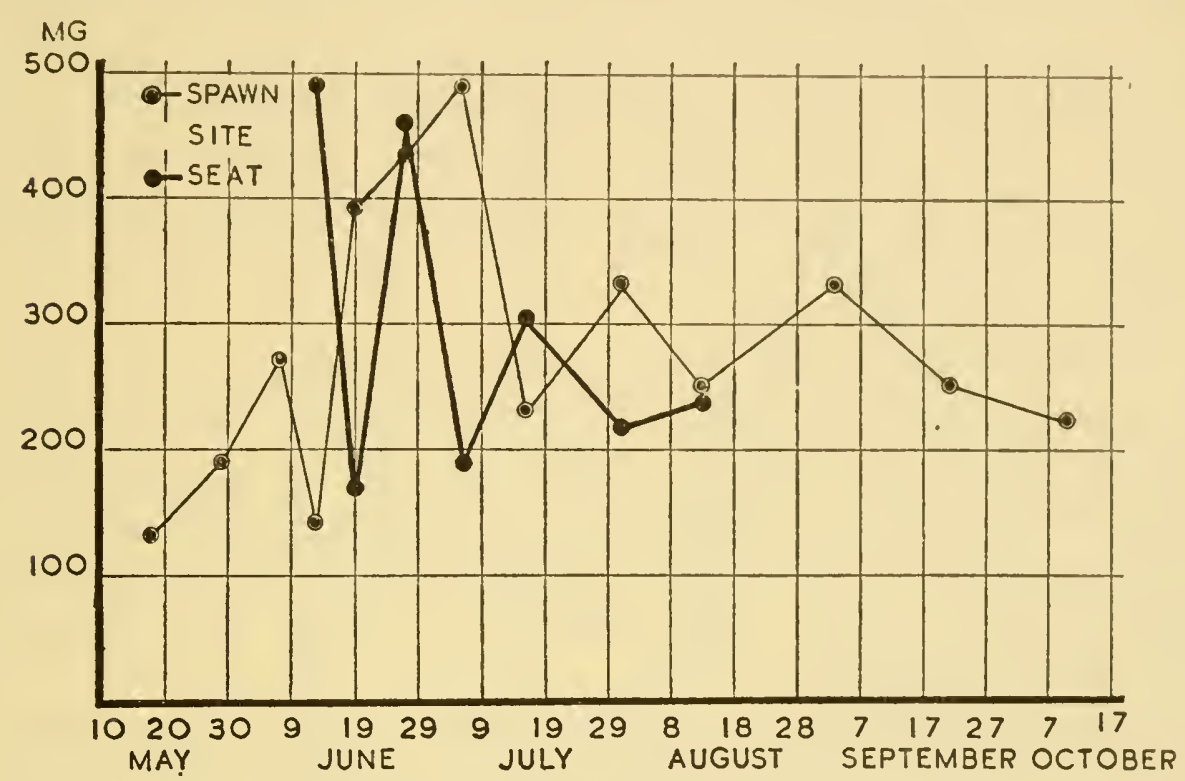

Fig. 8. Lower Parkfield, I947

Except for the fortunate few that metamorphosed about the middle of June, this was a year of disaster. From the beginning of July onwards to October, there was no growth, and the population consisted of emaciated animals in ever decreasing numbers.

sunshine and the autumn leaves fall into the pond, decaying slowly enough to form a substratum of rotting vegetation all the year round. Duckweed (Lemna) covers the pond, and for much of the time forms a continuous canopy. Some upright phanerogams of various species grow in the shallow margins, but there are never any conspicuous patches of algae. In wet weather the pond receives the overflow from another pond, Upper Parkfield, and it is possible that it is fed by springs, for the water level alters very little with the rainfall. Frogs lay their eggs near the point of entrance of the little stream, not always in the same place but certainly always in the same region of the pond. In 1947 the pond was not visited (nor indeed known) until I 8 th May, when a dense aggregation was found at "Spawn Site." Dispersal had 
evidently already begun, for tadpoles were to be seen almost everywhere, at a density of about 2-10 per $100 \mathrm{~cm}^{2}$ feeding on the bottom. On 29th May, many of the tadpoles were feeding on the surface film. On 7 th June, there were very large differences in size between the tadpoles and there was still no sign that any of them were metamorphosing. Fig. 8 should now be compared with Fig. 5 representing the events at Dagger Lane in the same year, and with Fig. 9 showing the events in Lower Parkfield in the next year, 1948. The contrast is very striking, for what is now being described is a catastrophe. The average weight of the tadpoles in this pond, collected at "Spawn Site" was only $270 \mathrm{mg}$. At Dagger Lane on the same date, the average weight from the lightest collection was $345 \mathrm{mg}$ and metamorphosed frogs had already been seen.

At the next visit on 13 th June the duckweed canopy was complete and movements of the tadpoles were not easily seen. A net sweep at "Spawn Site" showed that the animals were still abundant, but they were small (average I $40 \mathrm{mg}$ ) and were still far from metamorphosis. A net sweep at "Seat," only $8 \mathrm{~m}$ away, brought up many much larger tadpoles (average weight $480 \mathrm{mg}$ ) in a much more advanced state of development.

On rgth June, feeding movements could be seen among the duckweed. A net dip at "Spawn Site" collected many tadpoles, most of them large. At "Seat," a colony of much smaller tadpoles was found. Another collection was made alongside the wall at the point called "West." On 27th, the collections made at "Spawn Site" and at "Seat" differed little in weight but, on 7th July, the mean weight of the "Seat" tadpoles was only roo mg, although those at "Spawn Site" were more numerous with an average weight of $400 \mathrm{mg}$-that is, almost the reverse of the conditions of $\mathrm{I} 3 \mathrm{th}$ June. The population density in the pond was still very high-about one hundred tadpoles were collected in one net sweep at "Spawn Site." The first metamorphosed frog was seen on 7 th July. Fig. 8 shows that, up to this date, there were fairly large tadpoles in this pond, but that a decline in weight had now set in. Tadpoles in continuously decreasing numbers and having a decreasing weight continued to inhabit the pond until toth October, far beyond the normal date, although by this time, the miserably emaciated specimens were so few that they were not easy to find. On a final visit on 26 th October, none could be collected. I believe that the number of little frogs leaving the pond was far fewer 
than at Dagger Lane, in spite of the fact that the number of tadpoles during most of the season was much larger.

(b) I948 (Fig. 9). Although frogs were seen in Lower Parkficld on

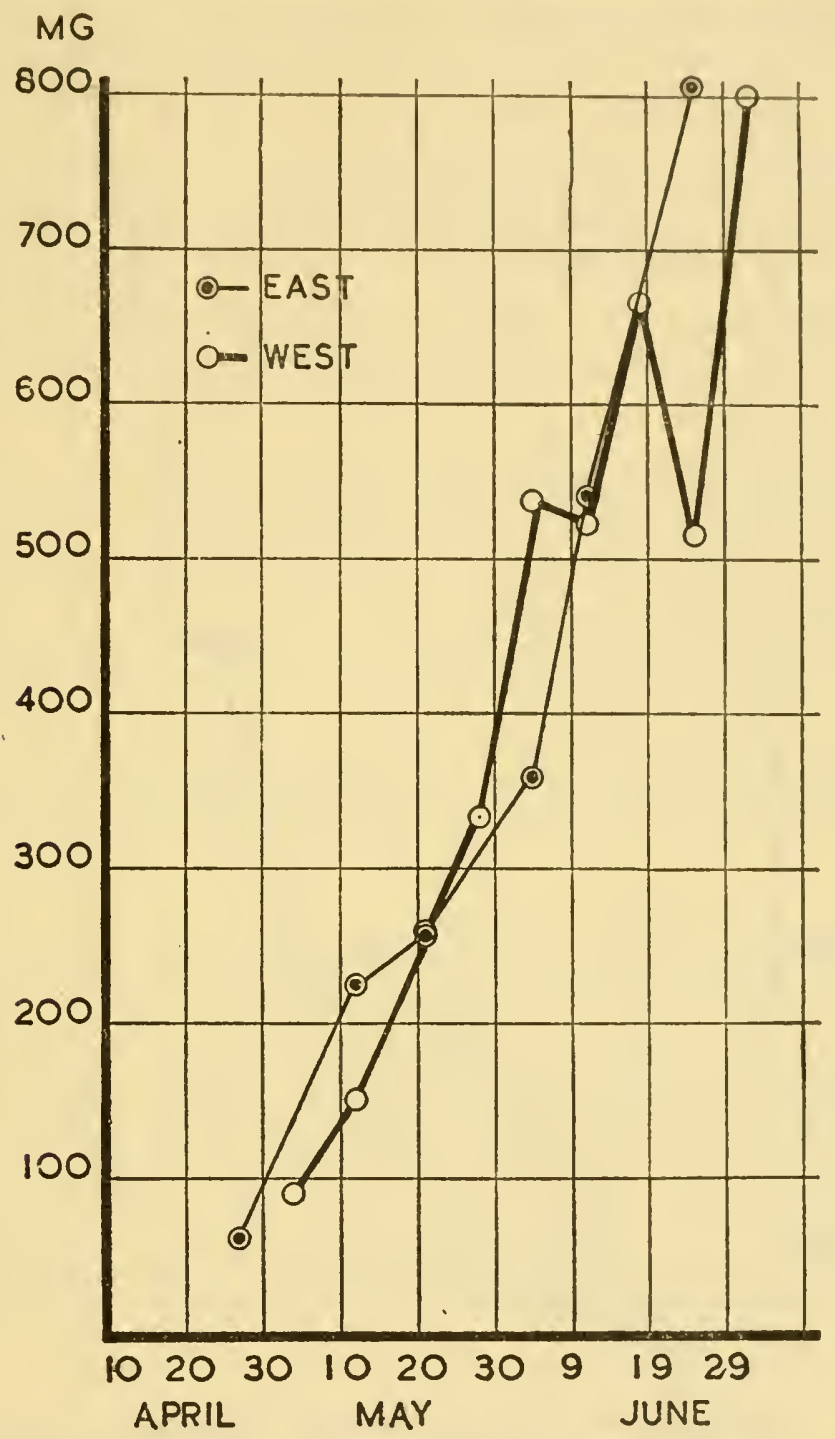

Fig. 9. Lower Parkfield Pond, I948

The great contrast with the preceding figure should be noted. The few tadpoles in this pond fared very well.

20th March, spawning did not begin until shortly before 27th. There were many clusters of spawn, forming a continuous mass about $2 \mathrm{~m}$ across. The tadpoles hatched on 20 th April and, in spite of the large numbers of eggs, the tadpoles did not seem to be numerous. On 27 th, 
the scarcity was even more obvious, and it was necessary to spend some time with the net before even ten tadpoles could be collected. The

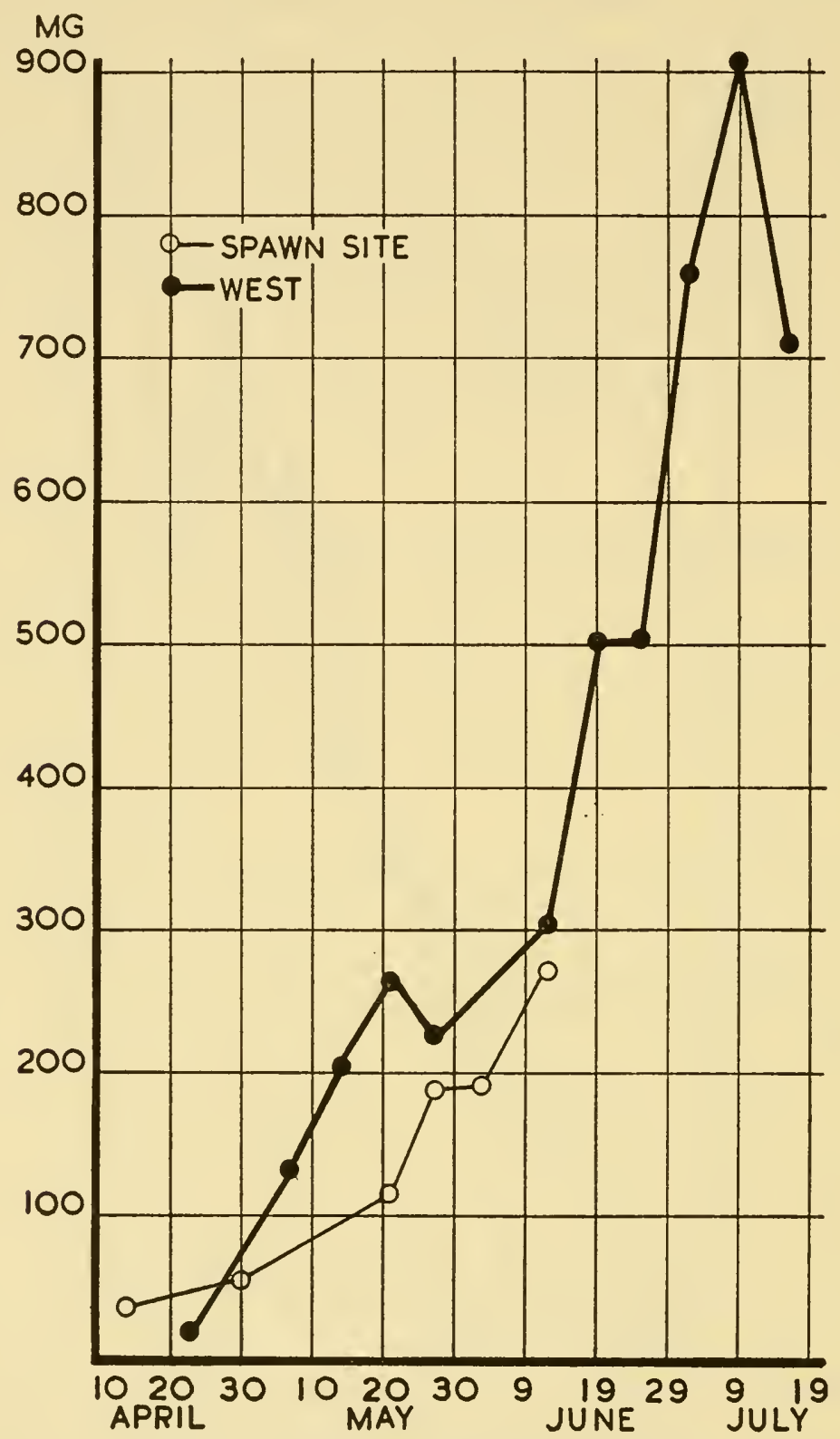

Fig. I0. Lower Parkfield Pond, I949

A similar graph to that for 1948. With few tadpoles in the pond, growth was good.

contrast with 1947, when hundreds could be collected in one sweep, was very striking. Fig. 9 shows that at no time were the differences between the weights of the tadpoles from different collecting points 
as great as in 1947, and also that by the middle of June the 1948 tadpoles were about twice the weight of those in 1947 at the same date, and considerably larger than those in Dagger Lane on the same date.

(c) I949 (Fig. Io). Several hundred clumps of spawn had been laid on 2nd April, not at the same place as in other years, but still in the same region of the pond. On I6th April, much of the spawn was spoiled. (This may have been another instance of the spoilage that follows late spawning, as discussed in Chapter I, for 2nd April is a late date for this area.) Only one tadpole was seen at "Spawn Site" on 23rd April, but there were a few at "West." As in 1948, the tadpole population was low throughout the season. Tadpoles could always be collected in small numbers at "West," but at no other place after the first few visits of the season. Fig. Io shows the poor progress made by the tadpoles at "Spawn Site" up to the last date when they could be found there at all. At "West," however, they began to grow rapidly after this date, and on 9th July, the average weight was over $900 \mathrm{mg}$. The collections from Ioth June to gth July contained tadpoles weighing a gram or more, weights not often exceeded in this investigation. Metamorphosis was beginning in July, and on I6th was still in progress, but many of the little frogs were found dead in the water at the foot of the wall.

Reviewing the events in Lower Parkfield, it can be seen that the steady progress found at Dagger Lane was absent in all three seasons. When many tadpoles survived the first few weeks, they fared badly afterwards. When disasters thinned the population in the early days, the survivors fared well. The contribution of Lower Parkfield to the total frog population of the area was probably always small.

With these two ponds described in detail, I now include a shorter account of two other ponds, each one resembling one of those already described.

\section{Hospital Pond}

This pond (Figs. I I and I2) was observed in two seasons, and on the whole the events resembled those at Dagger Lane, except that the growth rate was more rapid until about the later half of May, and then in each year slowed down so that the later tadpoles were not conspicuously large. Moreover, metamorphosis was noticeably late. In I949, the number of clumps of spawn was larger than I have ever known in one pond, and I estimated that the aggregation contained 
about five million tadpoles. In spite of this, however, the pond later in the season did not contain many.

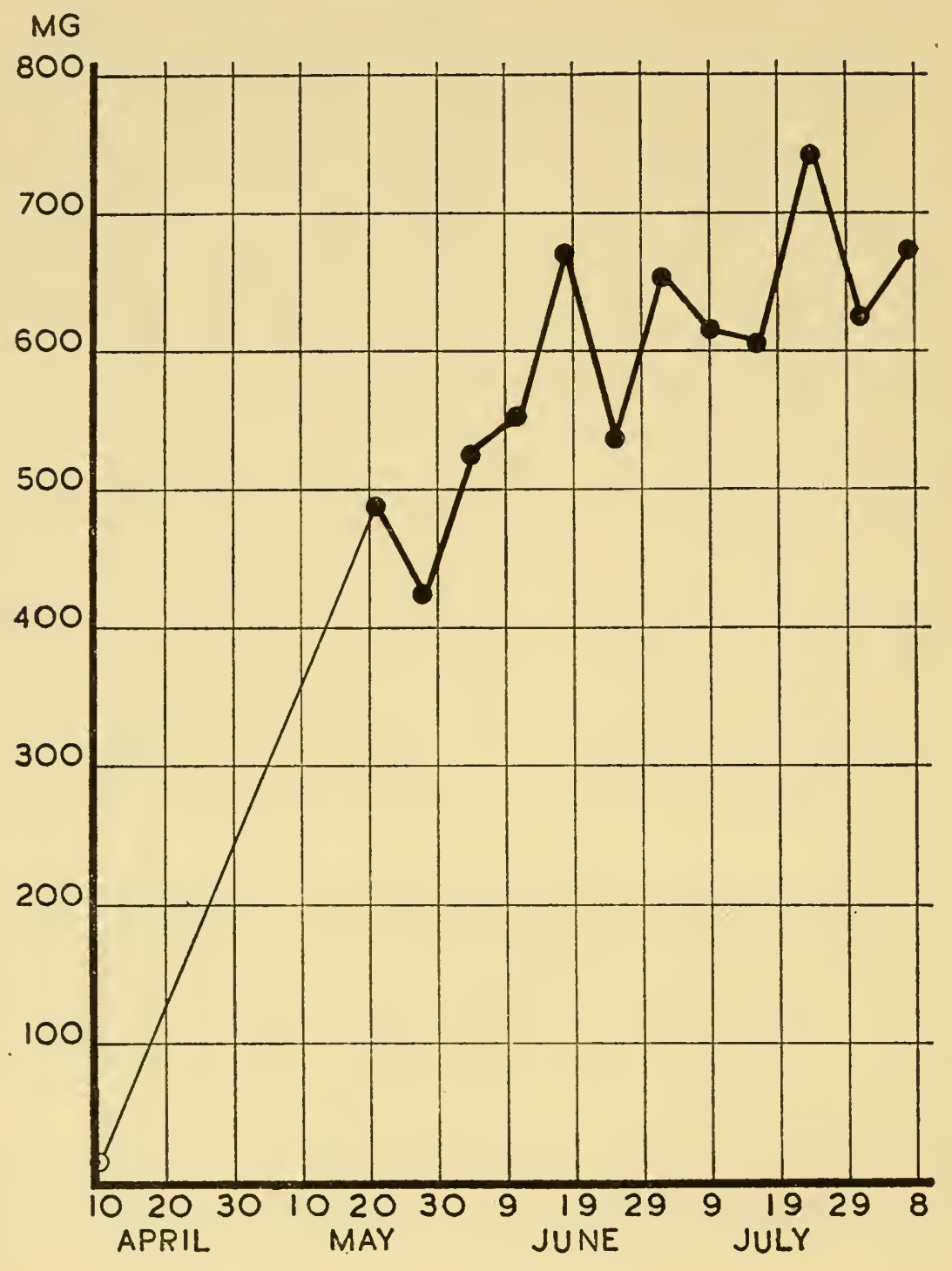

FIG. II. Hospital Pond, I948

This pond was not discovered until 2oth May, and the thin line is an extrapolation. The graph shows good growth, but somewhat delayed metamorphosis.

\section{Cat Hill Pond}

This pond (Fig. I3) was only observed in one season. The pond, like Lower Parkfield, is fringed with trees and has a permanent substratum of decaying leaves. Tadpoles were always scarce, but, as in Lower Parkfield in the later years, grew to an exceptional size, one 
reaching I,I93 $\mathrm{mg}$. There were large fluctuations in the size of successive collections at the same place, and it is likely that, in this pond as

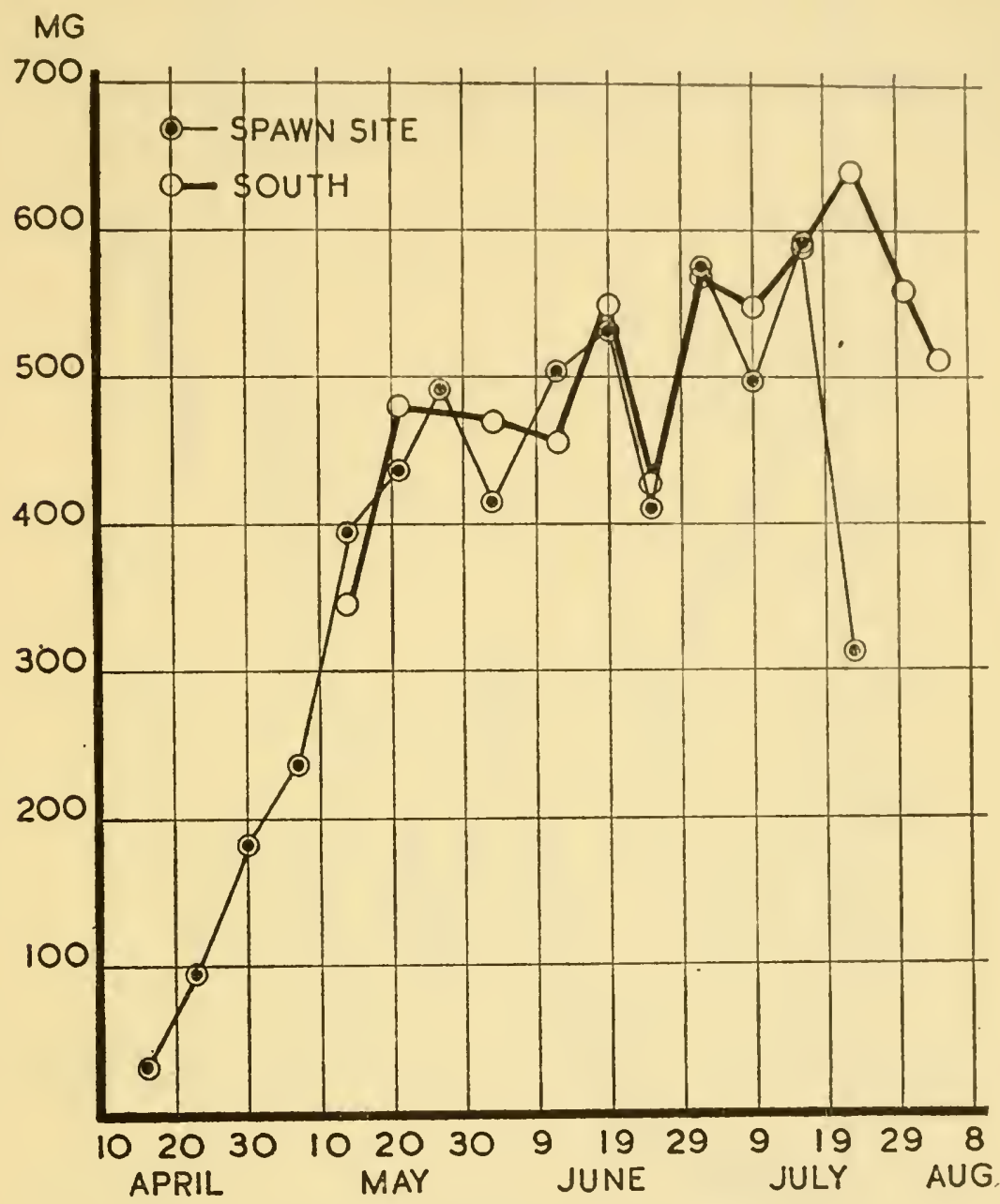

Fig. I2. Hospital Pond, I949

The same pond, observed throughout the season. The graph shows good growth, no great contrasts in the weights between the colonies, except on one date, and late metamorphosis.

in the others, there were nomadic colonies of tadpoles, some of which fared much better than others.

From these examples of ponds that were either known to have nurtured metamorphosed frogs, or at least probably did so, I turn to two others. In both, disaster overtook all the tadpoles. In one, an interesting colony was studied as a natural process of extinction took place. 


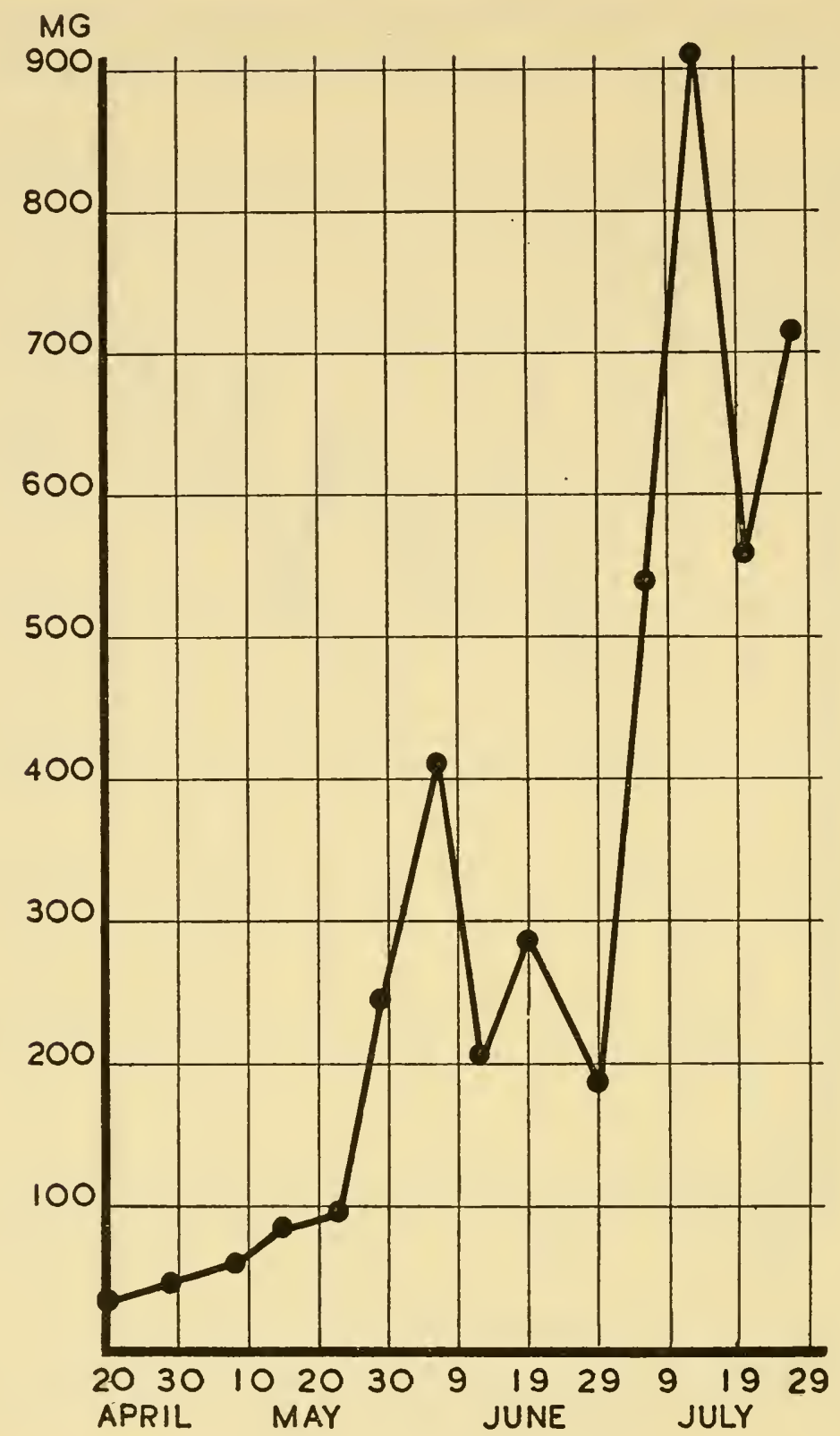

FIG. I3. Cat Hill Pond, I948

The collections, taken always at the same place, were remarkable for the contrasts in size. The large tadpoles probably came from some other place, never discovered, and departed again, as in other ponds.

\section{Bentley Heath Village}

I949 (Fig. I4). In I948, spawn was laid, but it was eaten by moorhens and, although a few tadpoles survived, none could be found after 20 th April. In 1949, however, Ioo to I so clumps were laid, in two lots, a 
rather exceptional event, although they were quite close together. Moorhens did not attack the spawn, but few tadpoles survived and, on Ist May, none could be found in the open pond. Some were, however, found in a small pool alongside a drain leading under the road. After three weeks, drought began to isolate this pool from the pond and, on I4th May, it only measured about $20 \times 24 \mathrm{~cm}$ and, on 2 Ist May, the
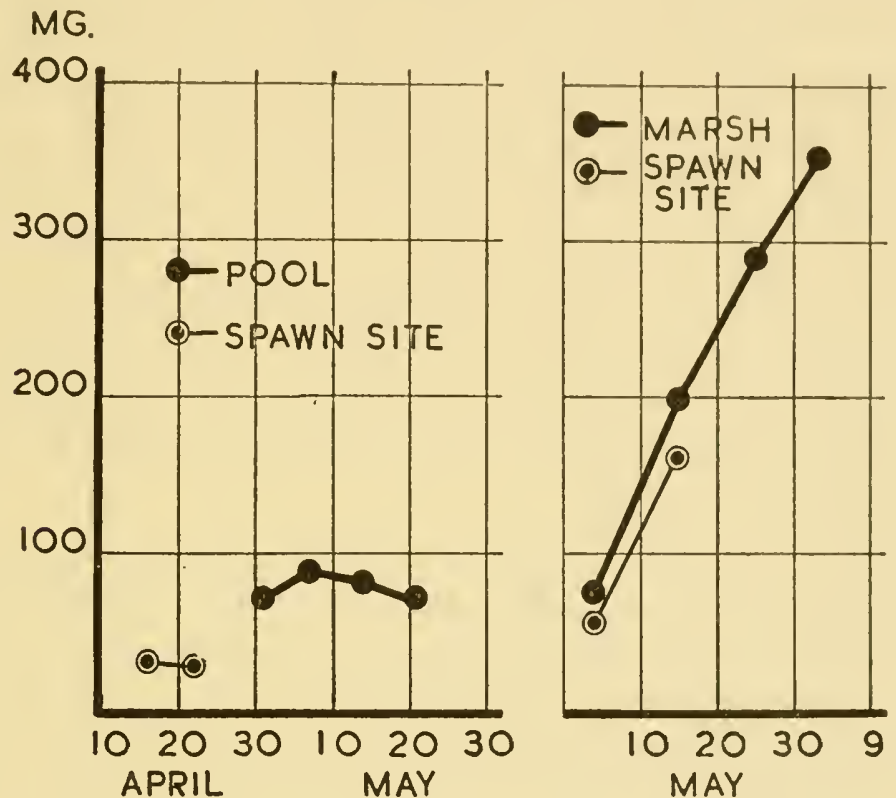

FIG. I4. Bentley Heath Village Pond, I949 (left)

A study of a doomed population in a pool that was drying up. Growth was good at first, and the decline set in under very crowded conditions.

Fig. I5. Green Street Pond, I947 (right)

Another study of a doomed population. The tadpoles in the marsh were in very small volumes of water, but not very crowded, and fared well until the end.

water was on the point of complete evaporation. The graph shows the changes in weight of a tadpole population at the limit of possible living conditions, brought about by entirely natural causes in a natural environment. It shows that until the conditions had become obviously desperate the tadpoles grew well.

\section{Green Street Pond}

I947 (Fig. I 5). Here the frogs laid about fifty clumps of spawn in a bay opening out of the marsh bordering the main pond, behind a bank 
of gravel. This was the normal place in all the years of observation of this pond. By rgth April, it became clear that, unless rain fell soon, the water in this bay would evaporate, the tadpoles would perish, and with them would disappear the opportunities of observation. I therefore transferred some of them to the main pond, leaving some in the pool at the spawn site. The graph shows that, although the tadpoles at the spawn site were apparently living in such unfavourable conditions, and the transferred tadpoles had all the pond to swim in, the two sets fared about equally. In fact, on Isth May, when the water at the spawn site was confined to a few hollows made by the hooves of a cow, the tadpoles in these holes had an average weight a little higher than those of the transferred tadpoles, living so far apart from one another that persistent efforts with the net were necessary to collect any. The rate of growth of the pond tadpoles was never high. It was, it is true, higher than in the very crowded conditions in Lower Parkfield at the same time, but lower than at Dagger Lane where tadpoles were much more numerous.

It will by now be clear that any attempt at a concise generalization summarizing the life of a tadpole would merely be inaccurate. It is, however, possible to point to some salient and recurring features.

Evidently, tadpoles living at liberty in the pond in which the parent frogs laid their eggs do not always have enough to eat. The catastrophe at Lower Parkfield admits of no other explanation, but, even in the other ponds, the maximum growth rate that the species is capable of reaching, for example at Cat Hill, is not often found. Moreover, the colonies of small tadpoles in a pond that also has colonies of larger tadpoles, quite a general phenomenon, must surely mean that there are some places that provide a better living than others. It must be remembered that usually all the tadpoles come originally from the same place, and hatch within a few days of each other. How does it happen that these colonies arise? What maintains the size differences, and how do these originate?

There is no difficulty about the origin of the size differences. In Chapter I it was shown that the tadpoles used for the chemical analyses differed considerably from batch to batch. All tadpoles are not born equal. Moreover, in the tadpole world, it is the thruster that gets ahead, as the following observations show.

I have no observations on $R$. temporaria to draw upon, and my example is taken from the toad, B. bufo. There is therefore an element 
of conjecture in transferring these observations to another species, but it seems likcly that something of the kind happens in the frog.

On one of the visits to Upper Parkficld Pond, which contained tadpoles of both species, I noticed that a large number of toad tadpoles had gathered round a slice of bread floating on the water. Wondering whether they were feeding on the bread itself, or on organisms attracted by the bread (B. bufo feeds mainly on plankton), I collected some of these tadpoles. When these were weighed, they were found to be significantly heavier than those collected at the same time from the procession of swimming tadpoles that made up most of the population. Next week, I took some bread and delibcratcly reproduced the same conditions. In a short time, a significant size difference was established. By watching the animals, it was possible to see what was happening. The bread was surrounded by a crowd of large tadpoles with vigorously waving tails. A small tadpole would approach, and be swept aside by the currents of water. The interesting thing was that the efforts of the small tadpoles did not persist. After one or two attempts, they gave up, and turned away to swim in the open water of the pond. There is surely nothing surprising in this. A weak tadpole will do better for itself in a second-class feeding ground, if it can feed there unmolested, than in a first-class place where the activities of its stronger competitors prevent it from feeding. This is just what happens in our own species, for it does not pay a man to attempt work far beyond his powers. He does better at an easier task that he can accomplish. If frog tadpoles behave as toad tadpoles do, then perhaps this is what happens: as soon as the tadpoles disperse, the largest of them find a good place to feed, and remain there until they have more or less exhausted the food. They then move off in search of another grazing ground. Very likely, this is occupied by smaller tadpoles, who now have to move. If they move to the place just vacated by the large tadpoles, we should have an explanation for the exchanges that take place. When there are not many tadpoles in the pond, it often scems that the biggest tadpoles are always found at the same place. Pcrhaps there are not enough of them to exhaust the food, so that there is no incentive to move. Lower Parkfield in 1948 and 1949 and Cat Hill may be examples of this.

I do not feel that the purely mechanical theory I have just outlined will explain all cases. Sometimes, there hardly seem cnough tadpoles for it to apply. It may be that something in tadpole psychology is involved, 
so that, for example, a tadpole tends to avoid the neighbourhood of larger specimens of its own species. This would seem to be in the best interests of the small tadpoles, and is only a small extension of the basic idea. There is experimental evidence that in other species kept in aquaria, overcrowding is associated with a diminished growth rate, from some kind of mutual interference with feeding (Lynn and Edelmann, I936, for $R$. sylvatica, Deansley and Parkes, I945, for Xenopus laevis). There is, of course, no doubt about the importance of this competition. To be late in metamorphosing is to risk desiccation or starvation, as the examples at Dagger Lane in 1947, or at Lower Parkfield in the same year, show quite clearly.

At this point, it may be useful to leave the detail for a time and to examine these size differences from another more general point of view.

To begin with, how real are these differences? The graphs show the size of the differences in the means, but not their significance. Although at the ponds the phenomenon was striking, it is quite easy in a long series of results to allow the attention to concentrate on the noteworthy events, and to ignore what might be the more usual case. I therefore subjected the whole series of collections at Dagger Lane I947 to an analysis of variance (Chapter ro, Appendix I a) with a result so highly significant that the further analyses that were planned were obviously superfluous-there is no doubt whatever that this is a general phenomenon, and a big one. The next question is: are the differences surprising? If tadpole ponds were large places, no one could be surprised to find colonies in distant parts of different sizes, but these ponds are so small that a large tadpole could swim across them in a few minutes. The expected event is surely complete randomization: what happens is marked segregation.

According to my observations, only about half the ponds which contain spawn support tadpoles all through the season as far as metamorphosis. In the rest, the tadpoles disappear at various dates in the season. It is, of course, impossible in practice to prove that a pond contains literally no tadpoles, but, even if there were a few in the ponds I have regarded as having none, it seems certain that the frog population of a district comes from very few of the ponds in it.

It may well be felt surprising that tadpoles living at liberty in the relatively vast spaces of a pond, well stocked with animal and vegetable life, should be so short of food. The explanation lies in the remarkable physiology of the animals, which forms the subject of the next chapter. 


\section{REFERENCES}

Since the post-embryonic ccology of $R$. temporaria tadpoles has no literature beyond the 1952 paper, this list of references could only be compiled by including papers that contained notes of interest on tadpoles of other species. The most extensive study is that of Bugayski (1930), but even this covered a very small field. It is probably true to say that literature on the ecology of tadpoles only exists in the form of snapshot observations, however interesting these sometimes are.

Bhattacharya, G. C. (1936) Curr. Sci. (Bangalore), 206.

Bragg, A. N. (1940) Amer. Nat., 74, 424-38.

Bugayski, W. (I930) Arch. Hydrob. Rybact., 5, 285-303.

Deansley, R. and Parkes, A. S. (I945) J. Endocrin., 4, No. 3, 324-55.

Hora, S. L. (I935) J. Bombay nat. Hist. Soc., 32, I I I-26.

Janes, R. G. (1939) Copeia, I34-40.

LI, J. C. and LIN, C. S. (I935) Peking nat. Hist. Bull., ro, No. I, 45-53.

Liv, C. C. (I943) J. W. China Border Res. Soc., B, No. I4, 39-78.

Lynn, W. G. and Edelmann, A. (1936) Ecology, I7, I04.

McCann, C. (1933) J. Bombay nat. Hist. Soc., 36, I \$2-80.

Noble, G. K. (I929) Bull. Amer. Mus. nat. Hist., 58, No. 7, 29 I-334.

Savage, R. M. (1952) Proc. zool. Soc. Lond., I22, No. 2, 467-5I4.

Sмith, M. A. (I9I6) J. nat. Hist. Soc. Siam, 2, No. 4, 26I-75.

Sмiтh, M. A. (1930) Bull. Raffles Mus., 3, II9.

Wood, W. F. (1935) Copeia, 100-2. 


\section{Chapter 3}

\section{THE RELATION BETWEEN THE ECOLOGY OF TADPOLES AND THEIR ANATOMY AND PHYSIOLOGY}

IN the last chapter, the events in the ponds were described without much attempt at explaining the underlying reasons. In this chapter, I attempt to show that at least some of these events can be traced to physiological and anatomical adaptations in the tadpoles. I shall, by drawing also on what knowledge we possess of other species of tadpoles, show how highly adapted to special environments even "normal" pond tadpoles are.

\section{Food and its Digestion}

The gut of a tadpole is never empty. Normally it is packed from one end to the other with some kind of material, and only in the emaciated tadpoles from Lower Parkfield late in 1947 were there any empty spaces. Yet the graphs clearly show that growth rates are often widely different, and that sometimes growth ceases altogether. The conclusion is inevitable-all that is in the gut cannot be food, and we are unable to judge whether the contents are really food unless we have simultaneous observations of the growth rates. Moreover, the faeces often contained much undigested material. Leaves and roots of duckweed were eaten in large quantities by the starving tadpoles in Lower Parkfield in 1947, but seemed to pass through quite unchanged. Hospital Pond in one year contained quantities of the spherical alga, Volvox globator, and intact spheres passed into the faeces. Many of the algal filaments and unicellular forms were found in the hinder parts of the gut with their contents reacting to stains as if they had been collected from the pond itself.

There was obviously something peculiar about the digestive process in tadpoles, and a test was arranged in which they were first fed a coloured meal and then placed in Petri dishes for continuous observation. It was found that food passed through at a truly astonishing rate. The average for four experiments on $R$. temporaria was only $6 \frac{1}{4}$ hours, with one time of $4 \frac{3}{4}$, and a tadpole of $B$. bufo passed coloured faeces only $3 \frac{3}{4}$ hours after the beginning of the experiment. 
To get these times into proper perspective, it is necessary to compare them with those found in other animals. The digestive enzymes of homoiothermous animals such as the mammals do not seen to have temperature optima different from those of the poikilotherms, so that we should expect that animals such as cows, which also eat vegetable food, but digest at about $37^{\circ} \mathrm{C}$, should be able to complete the process in much less time. But digestion in the cow takes 18 hours. Using the common assumption that a rise of $10^{\circ} \mathrm{C}$ doubles the rate of reaction, five hours in the tadpole corresponds to less than two in the cow. Digestion in the mammal has by then scarcely begun. In a review, Barrington (1942) has collected many obscrvations on digestion in the lower vertebrates. For example, the dogfish, Scyllium, sometimes takes i 8 days to digest a meal, even though it lives on animal food, which is more digestible than vegetable. A carp takes 18 hours at $10^{\circ} \mathrm{C}$ or $4 \frac{1}{2}$ at $26^{\circ} \mathrm{C}$. Sokolov and Chvaliova (1936) reported that the stomach of the fish Gambusia is completely emptied of a meal of Anopheles or of Daphnia in 3 to 4 hours at $30^{\circ} \mathrm{C}$, and Barrington considered this a remarkably short time. This comment emphasizes the exceptional nature of digestion in the tadpole, for this animal not merely emptics one part of its alimentary canal in this time at a much lower temperature, but empties the whole of it, and yet lives on relatively indigestible food. Direct evidence for cellulose digestion was sought by the methods of Baker and Nasr (I948), who employed direct microscopic observation of areas of attack by enzymes. This method, although devised for studying farm animals, was adapted for use in tadpoles. There was no evidence that cellulose was being digested and, indeed, having regard to the known properties of cellulases, which take a long time to act, it would be astonishing if any activity could be seen after such a short time. We must therefore accept the idea that tadpolcs cannot digest cellulose. But they can live on algae, cnclosed within cellulose walls. The field observations showed that in some ponds, such as Dagger Lane, algae predominated in the dict, and there seemed to be a relation between the growth of the algae and that of the tadpoles. These observations were supported by experiments in which artificial and rapidly growing cultures of single species of various algae were used as food for tadpoles put to live in the culture vessels. The tadpoles grew well at first, but in one year died before metamorphosis, and in the next, were clearly about to do so, and were fixed at this time. How can we reconcile these somewhat conflicting observations? 
In some cases, when the algae are delicate, it seems likely that the vigorous peristaltic movements of the intestines is sufficient to rupture the cells and release the contents. Li and Lin (1936), studying the tadpoles of Kaloula borealis, found some digestion of euglenoid organisms such as Euglena and Phacus, and I have found that the cells of Scenedesmus, a delicate planktonic species, are often empty in the gut. $\mathrm{Li}$ and $\mathrm{Lin}$ found that diatoms passed through undigested, which contrasts with the observations of Fish (I9SI) who found that unless the fish Tilapia can eat diatoms, it cannot survive, for it, too, cannot digest the cellulose of the other algae which may be abundant in its lakes. $\mathrm{Li}$ and $\mathrm{Lin}$ considered that the algae did not form an important source of food, but that their tadpoles lived chiefly on Protozoa, a matter to which I shall return. I think that the evidence that the tadpoles of $R$. temporaria, at any rate, can live on algae is conclusive. Other food, however, is always taken.

The two ponds, Dagger Lane and Hospital, were examples of ponds, in which the tadpoles appeared to live mainly on algae, and in both the tadpoles metamorphosed while still far short of the maximum size that the species can reach. By contrast, some of the tadpoles in Lower Parkfield, except in the abnormal year of starvation, and in Cat Hill, grew to the largest size found in this investigation, and the main food found in the gut consisted of Entomostracae, with much debris. The tadpoles, in their ceaseless task of ingestion, get this nourishing food, as it were, by accident. This same habit probably serves to tide the animals over a temporary shortage of food for, indigestible as the Phanerogams may be, it is probably better to eat them than to eat nothing. As for the mud which is often present in abundance, this may well contain a sufficient quantity of food to be well worth eating, when it is considered what enormous quantities pass through in one day. The tadpole (C98) from Papua, of unknown species, apparently specialized in eating heavy mud, which was counterbalanced by the extraordinary development of its float-like lungs (Fig. I6 a).

Another result of this habit of somewhat indiscriminate engulfing is that even the tadpoles that live largely on algae get animal food, for the tests of the Protozoa Arcella and Difflugia, which climb about the plants, are common in the gut. How many amoebae and other soft animals were originally there can only be imagined, for they would be rapidly digested. When it is considered that only a fraction of the algae is digested, but probably all the soft animals, the relative 
importance of the types of food becomes difficult to assess. It is very likely that even the "vegetarian" tadpoles obtained much of their nourishment from animal food.

Gudernatsch and Hoffman (1936) fed different amino acids to tadpoles of R. sylvatica. Some allowed growth without much differentiation, others differentiation with little growth, and some allowed both to occur. It is certain that the amino-acid composition of the very varied dict of tadpoles must vary considerably, and this may be one reason for the variations in size.

One of the implications of the fact that in some ponds the tadpoles live on animal food, and in others on vegetable food, is that there is one more link in the food chain in the former. It is well known that each link in the chain reduces the numbers of organisms of the same size that can be supported in the same environment. Macan and Worthington say (I95I) that each link reduces the number to one seventh. It is certainly true that the population in the ponds with the large tadpoles feeding on animal food was far smaller than in the others, and that disaster overtook those in such a pond when the numbers were large.

A point of interest, not yet solved, is how the tadpoles manage to digest Crustacea in the short time available. The Crustacea are invested with a remarkably complete cuticle of chitin, a material not easily acted upon by enzymes, yet dead and swollen Crustacea are seen in the gut. As pure conjecture, I suggest that with these quite small animals, the peristaltic movements of the tadpole's gut, which are very vigorous, may be sufficient to pump out the contents of the gut of the Entomostracan, and to replace them with digestive juices, so that the prey is digested from within. There is a small part of the gut of Crustacea that is not lined with chitin and, after all, it is often only a fraction of a millimetre from either end. As another speculation, I have wondered whether the gut contents of the prey might not be very useful, consisting as it does of comminuted and partly digested algae.

The ingestion of Crustacea by tadpoles of American species is part of the pattern of life, for the trematode Halipegus eccentricus gains access to tadpoles by first infesting Cyclops, which are then caten by the tadpoles (Thomas, I939).

In the description of the behaviour of the tadpoles in Lower Parkfield, I wrote that on the date concerned the tadpoles were feeding on the surface film. It may not be realized that the term "surface film" 

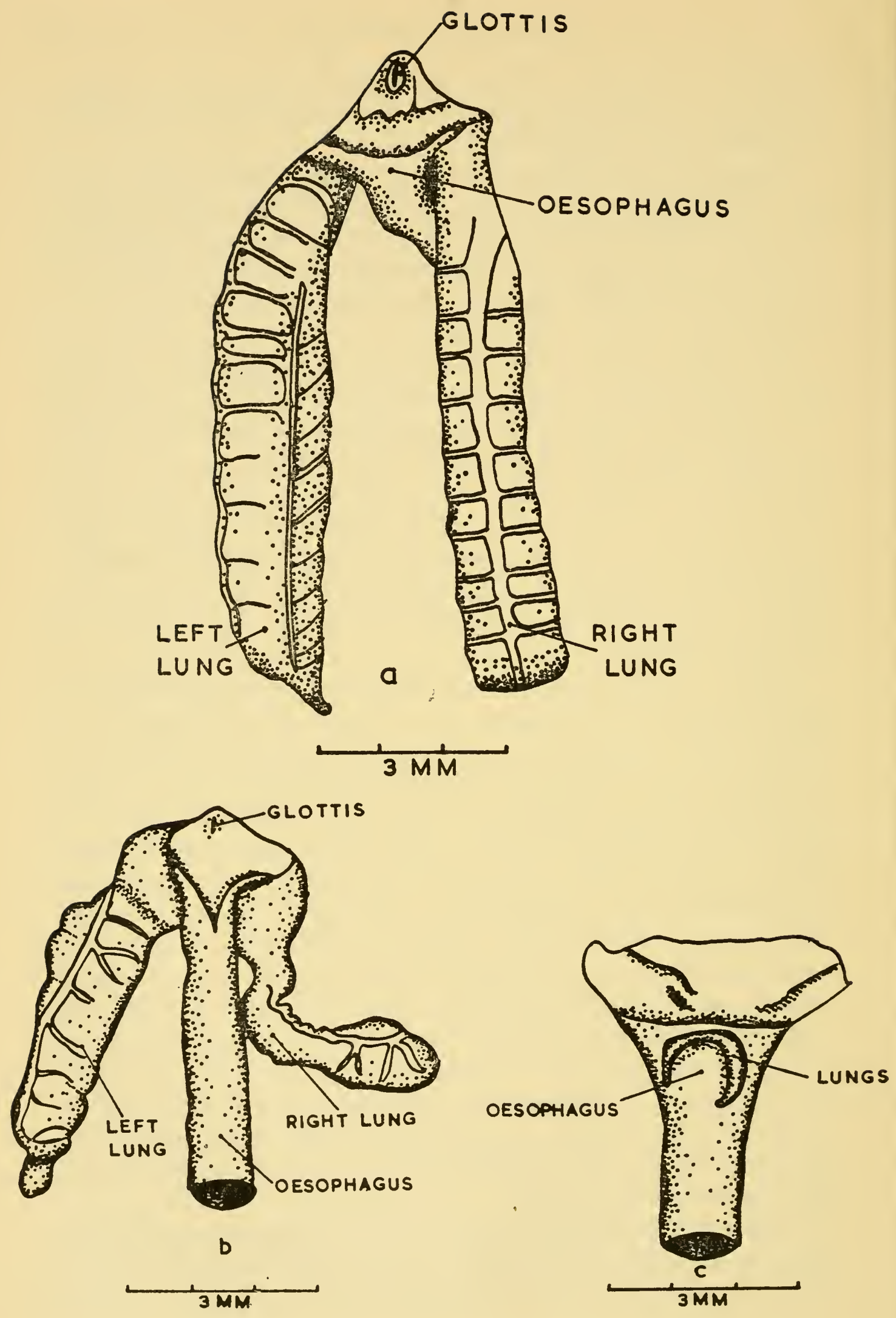
is used in two entirely different ways. In the physical sense, it is no more than a region where the surface encrgy relations are different from those in the depths of the water. Goldacre (1949) has shown that on natural waters, there is a surface film, consisting of a protein or lipo-protein, and so far from this being a physical fiction, it is definitely food. Goldacre calculated that if a tadpole continued to cat it at the same rate as it did when under observation it could cat an amount equal to its own dry weight every day. A tadpole that turns itself upside down and grazes at the film is not wasting its time.

The tadpole has no gastric mill, and we must now pass to consider what apparatus it has for effecting even a limited amount of breaking of the algal cells, and also the remainder of the digestive anatomy, so far as it affects the ecology and life history of the animal.

\section{Digestive Anatomy}

The beak of the tadpole is a pair of shears, so effective that it can sever cleanly the roots of duckweed, which in relation to the size of the animal, are quite large objects. The beak can also be brought to bear on flat surfaces, and it is no doubt in this way that the tadpole eats the sessile algae. A more puzzling feature is to be found in the rows of cuticular teeth that surround the mouth. A high speed cinema film lent some support to the idea that these teeth are scarifying devices, serving to break open some of the algal cells before the beak detaches them for, just before the beak closes, the small teeth can be seen to sweep over the surface of the glass through which the film was taken.

It seems surprising that, with all this apparatus for cutting and scraping food, the tadpoles in the end seem to utilize so little of the algae they eat. But they are not alone in what appears to us to be such a wasteful method of feeding. In the Mollusca, Fretter (1936) has shown

FIG. 16. The Lungs of Three Species of Tadpoles

(a) An undescribed species (C98) from Papua, found in temporary water in a wheel-rut.

(b) R. temporaria, also at times an inhabitant of small, badly oxygenated ponds. Lung development less than $\mathrm{C}_{98}$, but much more than that of B. bufo.

(c) B. bufo, an inhabitant of large clean ponds. No functional lungs, so that the animal is entirely dependent on a sufficient supply of dissolved oxygen. The lungs are so small that it was necessary to draw the dissection from the ventral side in order to show them at all. 
that Polyplacophora can only digest those algal cells that happen to be pierced by the teeth on the radula, an organ that has some resemblances to the cuticular teeth of the tadpole. It is a wasteful method of feeding, but in both cases it works. In tadpoles, we know that sometimes it would seem to be much better if more efficient methods were in use, for then there would be enough to go round even in the lean years. But this is how the tadpole has evolved, and it is the total effect that counts. If the rate of reproduction is suitably geared to allow the occasional catastrophes to occur without extinction, that is the end of the matter, for the species is not concerned with human ideas of efficiency.

If we now follow the food in its journey through the tadpole, we come soon to another problem. At one time, the tadpole may be feeding on such large objects as Daphnia, or even larger animals (a spider was once found), and at the next, it may be collecting thousands of small unicellular algae, or even bacteria. One could hardly expect that the same mechanism would serve both ends and, in fact, there are two.

\section{Pharyngeal Anatomy and Physiology}

When the pharynx of a tadpole is opened from the dorsal side, a conspicuous organ, the velum, can be seen. The velum is actually a single organ in the form of a tilted annulus with a gap in it at the centre of the dorsal portion, but the structure and function of the dorsal and ventral parts are so different that it seems better to treat these parts as if they were separate organs.

Fig. I7 shows a sectional view of an actual tadpole, and Fig. I 8 a diagrammatic view. The ventral velum is a substantial, somewhat muscular organ, and to judge from the different positions of its edge in different specimens it seems probable that it directs the entering stream of water differently at different times. When the edge of the velum is raised, the water must strike the roof of the pharynx at a point anterior to the dorsal velum. This is a much thinner fold of tissue than the ventral velum, and can be opened like a sail if a stream of water is directed at it. Consideration of the hydrodynamic relations of the parts makes it certain that behind the dorsal velum there would be an eddy. Particles collect in eddies and this is where, on dissection, one finds food particles. Bles (I905) described ciliated grooves on each side of the pharynx of Xenopus laevis and said that water green with 
Chlamydomonas could be seen "passing back in a kind of helicoidal vortex towards the oesophagus, where the two green currents converge and disappear." Kratochwill (1933) has a drawing of a section of these parts of $R$. agilis showing food particles in this place. Dodd (1950) was probably the first to publish the fact that mucous cords form there

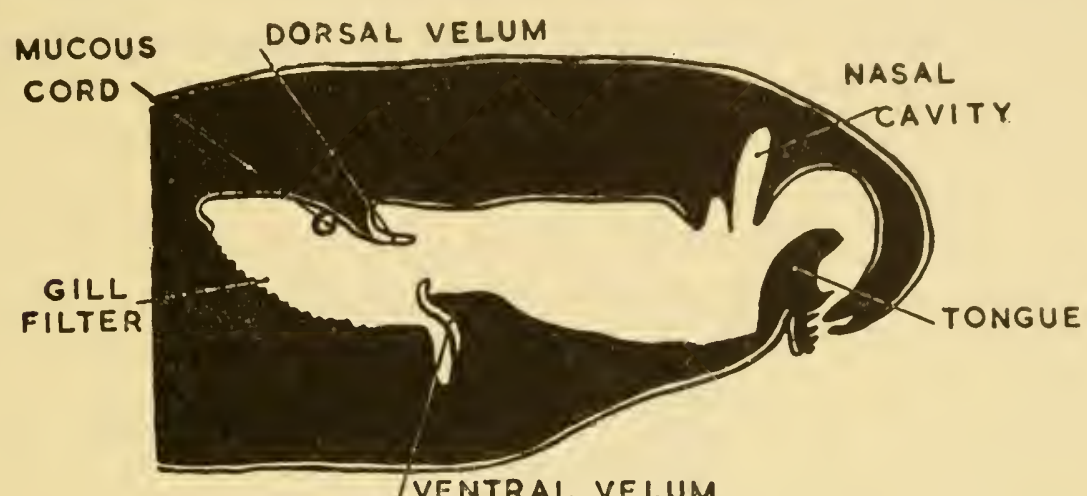

FIG. 17. Sagittal Section of a Tadpole of $R$. temporaria, Showing the Structures of Importance in Feeding

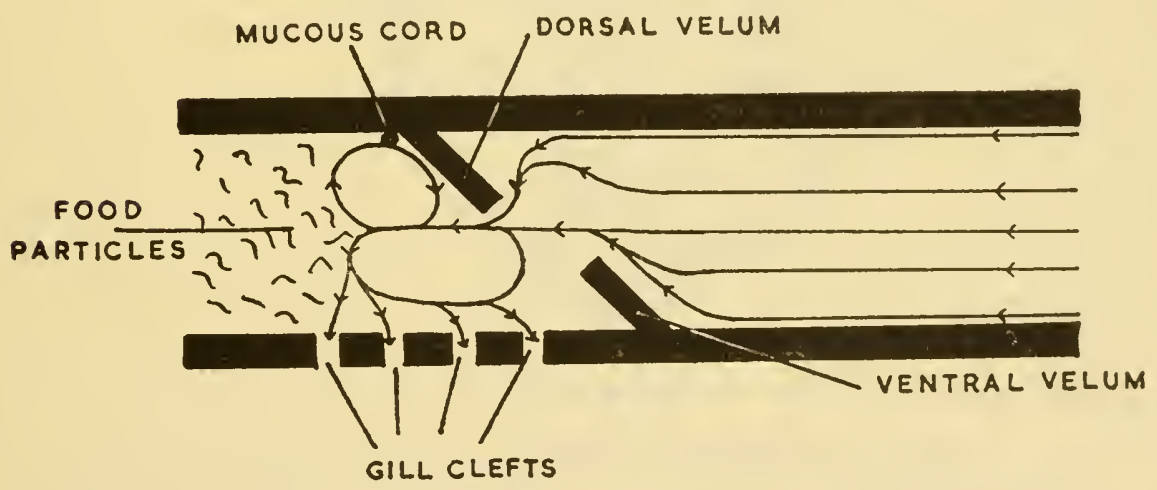

FIG. I8. Diagrammatic View of the Mouth and Pharynx of a Tadpole, Showing the Path Taken by the Water and the Structures of Importance in Feeding

in R. temporaria and in B. bufo. I have seen them in these species and also in Bombina variegata, and several species of Microhylidac. This is such a range of Anuran families that probably mucous cord microphagy is a general method of feeding in tadpoles. The mucous cords, with entangled food particles, are moved by cilia towards the wide ocsophageal funnel, down which they plunge. Sometimes, the cords are tangled in the œesophagus, but in the Microhylid tadpole, Hypopachus 
aguae, specialization has gone so far that each cord has it own tunnel in a divided œsophagus, as shown in Fig. I9. This neat arrangement obviously prevents the ingestion of particles of any great size, and $H$. aguae is presumably exclusively a microphagous feeder. $R$. temporaria is more versatile, for it has another method at its disposal. If Fig. 17 or I8 is studied, it can be seen that the direction of the stream of water changes suddenly at the posterior end of the pharynx. This would

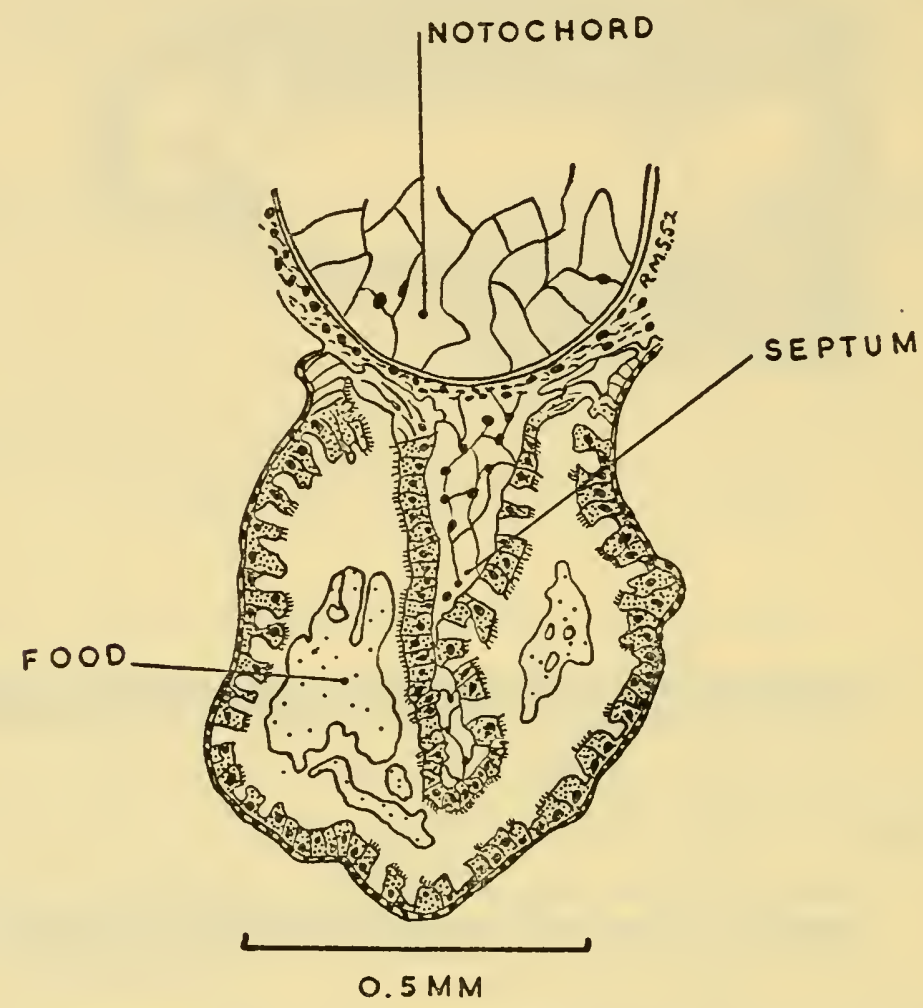

Fig. 19. Transverse Section of the Esophagus of a Tadpole of Hypopachus aguae Showing the Two Separate Channels for the Mucous Cords

throw any large particles into the wide œsophageal funnel by centrifugal force, and these would be conveyed down the osophagus by ciliary action.

It has been suggested that the gill filters are food-collecting organs, and so they are in a limited sense. It seems to have been overlooked that filters of any kind are always intermittently-operated structures, and that, since they are not ciliated, there is nothing to move food collecting on them to the osophagus except the water currents, into which the food is probably thrown at intervals by a process of back- 
washing. The filters can, however, be regarded as food-concentrating organs. It is possible that the need for backwashing with clean water, essential if the filter is not to be hopelessly blocked on both sides, accounts for the atrium of the tadpole. This space always contains filtered water, however muddy the water of the pond may be.

It is interesting that Strawinski (1956), in giving some reasons for supposing that the gill filters in $R$. esculenta have little respiratory function, considers that they are often covered with food and mucus. This I have never seen in $R$. temporaria-the filters may occasionally have some particles of food upon them but never to any great extent. Whether this is a species difference it is hard to say, but almost all my tadpoles were anaesthetized before fixing. This was partly because I dislike killing animals, but also because animals killed violently may regurgitate food. I feel rather doubtful whether a live tadpole has much food on the filters at any time, because they depend for their functioning on being sufficiently free to pass large quantities of water. I believe that their main nutritional function is to trap whatever misses the mucous cords or centrifugal mechanisms.

The existence of these two feeding mechanisms is another illustration of the versatility of the tadpole. It can feed either on very small particles or on quite large ones, and its ability to colonize many different types of pond may depend on its digestive physiology. Hypopachus aguae would surely starve in a pond that only had Entomostracae as food, unless it could compete with the Crustacea for the microscopic organisms. Microhyla heymonsii has a mouth shaped like a funnel, and apparently specially adapted to collect the surface film. It could surely not thrive except in ponds where this was abundant. $R$. temporaria can live in a variety of habitats.

\section{Respiration}

The same current of water that brings food into the tadpole also serves for respiration. This is not by any means the only method, and since the subject has been illuminated by an extcnsive research of Strawinski (1956), it has now become possible to view it in the light of more detailed anatomical and physiological information than was available before. The various methods have a considerable degree of independence, and it sometimes seems that it is easier for purposes of description to separate the different methods of respiration from one another than it is to separate respiration from ingestion. 
Strawinski worked on $R$. esculenta, and in transferring his results to other species, it is necessary to remember that this is an act of extrapolation, and that, in the respiratory and digestive systems, we are dealing with structures in very close contact with the environment, and so liable to considerable modifications according to the ecology of the particular species. In fact these structures are avoided by systematists, precisely because, for their purposes, such systems may be unreliable guides to relationships. Nevertheless, it seems unlikely that $R$. esculenta differs so much from $R$. temporaria, or even more remotely related species, as to invalidate completely Strawinski's results when applied to them. What is needed is a cautious approach when something appears to be different.

Strawinski finds that the principal respiratory surface is the skin. He considers that the internal gills are only a supplementary respiratory organ, and that, late in development, the lungs take over the first place. The inner surface of the operculum is important, but the filtering apparatus contributes very little to respiration. External gills are so poorly developed in this species that they do not play any important part. The tail, which others (Medvedev, I937) have thought respiratory, is poorly supplied by respiratory capillaries.

The relation of the above facts to the ecology of the animals can now be considered. It is interesting to see the low place given to the external gills, because this is much what would be expected from the different ecology of the two species. R. esculenta does not lay its eggs in one large mass, but in comparatively small packets in separated places. I am not very familiar with the species in the field but, from what I have seen, I should be surprised if the dense aggregations of $R$. temporaria tadpoles are usually formed. The conditions I suggested in the last chapter as being those that make external gills important probably do not occur in this species. Tadpoles, living in unstable environments, must be versatile, and $R$. temporaria uses its lungs from a very early stage, but I think that this is an adaptation to life in ponds that would be too dangerous for species without lungs, or to foodfinding in parts of a pond too lacking in oxygen for such species. For example, $B$. bufo, which is lungless until just before metamorphosis, does not occur in the small polluted ponds that are sometimes used by $R$. temporaria, but favours larger and better-oxygenated ponds. In Upper Parkfield, both species occurred. The toad tadpoles spent the whole season milling round in shoals just beneath the surface of the 
water, and were not accompanied by any frog tadpoles. A short distance away, frog tadpoles fed on the bottom of the pond, unaccompanied by any toad tadpoles, and made journeys to the surface for air. These visits were hurried affairs-when watching the surface, a tadpole could be seen swimming up very rapidly. It would break surface, and without pause would swim down again as rapidly as it appeared. The impression was irresistible-there was no time to waste, but air had to be taken. The lungs are only onc of the organs of respiration, but they may make all the difference between one kind of life and another, as I shall show in the next paragraph.

In small ponds, fluctuations occur in both the food supply and in the oxygen. The oxygen variations may be due to two distinct causes. Plants respire continuously, but carry out photosynthesis only by day. If the plant population is large, respiration by night may be so intense that the oxygen, plentiful by day, may then be reduced to dangerous levels. In the second method, shrinking pools in the summer may become the site of so much bacterial action that oxygen is depleted in this way, even by day.

The lungs of a tadpole vary greatly in different species. B. bufo as mentioned above, is lungless (Fig. I6 c). The Papuan, C98 species (Fig. I6 a) has the largest I have seen. In this case, they are probably used partly as floats, balancing the large gut, loaded with mud, but the glottis is well developed, and the lungs may be of special importance in tropical mud. Ventilation of these enormous sacs was probably effected by pressure from the powerful tail muscles, for the lungs, almost rectangular in section, were strongly adherent to them and were packed between them and the notochord so that, when the muscles contracted and became thicker, the flat surfaces of the lungs must have been pressed together. It was doubtless in this way that the gases in the lungs became interchanged with those in the pharynx. R. temporaria (Fig. I6 b) has smaller lungs than C98, but is much nearer to it in this respect than it is to B. bufo. It is obvious from the figures that animals with such extreme differences in respiratory anatomy as these can live very different lives. C98 was collected from water in a wheel-rut, a very restricted environment. $R$. temporaria can live and thrive in similar places, if it can escape drought. B. bufo must have ponds with a reliable oxygen supply. Frog and toad tadpoles are often found in the same ponds, but this is because frog tadpoles can live in toad ponds, not because the toad is equally adaptable. 
Strawinski found, as stated above, that the gill filters have very little respiratory function, and even that the gills themselves are not very important. On the other hand, he found that the inner surface of the operculum is highly respiratory. Perhaps we make too much of anatomical distinctions, and should rather consider $(a)$ lungs, $(b)$ skin, and $(c)$ the whole respiratory channel as three units. The first two are clearly distinct, but buccal cavity, gill filters, gills and operculum are only subdivisions of one system $(c)$, which perhaps may share the functions in different proportions in different species.

I have suggested (1952 and 1955) that the respiratory systems in tadpoles are connected with the ecology in the following way. If a tadpole lives in an environment rich in food, as many temporary or polluted ponds are, it does not need to pump much water to get its food, and so does not need large gill filters. To use the oxygen under these conditions, however, it must have large gills, and needs lungs to tide it over emergencies. If, however, it lives in the oligotrophic type of pond, with plentiful and almost constant supplies of oxygen but with a low concentration of food, it needs to pump much water, and so must have large gill filters. With these, gills might not be necessary, because of the large surface of the filters (or rather, in view of Strawinski's work, more probably, the associated large operculum). In ordinary ponds, intermediate as habitats, the arrangements might be expected to be intermediate also.

There is a good deal of conjecture in all this. but the Microhylids seem to provide examples. Some have such large gill filaments that they trail in the opercular cavity in a way quite unlike those of Rana, others have no gills but have enormous gill filters, for example Glyphoglossus molossus. Some, such as Hypopachus aguae, are intermediate and live in ordinary ponds. $R$. temporaria also has a moderate development of gills, filters and lungs, and lives in ordinary ponds.

The respiratory arrangements in tadpoles underline what I believe to be points of fundamental importance in Anuran ecology - the great degree of specialized adaptation to the environment, which enables the different species to colonize habitats in great variety, from tree holes to puddles, from lakes to cow-ponds, from mountain streams to dry land. The common feature of most of these habitats is that they confine the tadpoles within usually quite small limits. If the conditions in their pond turn out to be dangerous they cannot go in search of better ones, as animals that live on dry land or in the sea can do, but 
must possess reserve mechanisms that can be brought into play to deal with the often violent fluctuations in the habitats.

\section{REFERENCES}

BAKER, F. and NASR, H. (1948) J. R. micr. Soc 67, 27-42.

Barrington, E. J. W. (1942) Biol. Rcv., 17, I-27.

Bles, E. J. (I905) Trans. roy. Soc. Edin., 4I, 789-82 I.

Dodd, J. M. (1950) Nature, Lond., 165, 283.

Fish, G. R. (I95I) Nature, Lond., 167, 900.

Fretter, V. (1936) Trails. roy. Soc. Edin., 59, I I9-64.

Goldacre, E. J. (1949) J. Anim. Ecol., 18, 36-9.

Gudernatsch, F. and Hoffman, O. (1936-7) Roux Arch. Entw Mech. Org., 135, I36-I77.

Kratochwill, K. (1933) Z. wiss. Zool., 164, 42 I-68.

LI, J. C. and Lin, C. S. (1936) Pcking nat. Hist. Bull., Io, No. I, 45-53.

Macan, T. T. and Worthington, E. B. (I95I) Life in Lakes and Rivers (Collins, London).

Medvedev, L (1937) Zool., I6, 393 (Not seen.)

Savage, R. M. (I9S2) Proc. zool. Soc. Lond., I22, 467-5I4.

Savage, R. M. (I955) Copeia, 2, I20-7.

Sokolov, N. P. and Chvaliova, M. A (1936) J. Anim. Ecol., 5, 390-s.

Strawinski, S. (1956) Zoologica Poloniae, 7, 3, 327-65.

Thomas, L. J. (1939) J. Parasit., 25, 207-21. 


\section{Chapter 4}

\section{PARASITES, PREDATORS AND SOME PROBLEMS OF ABUNDANCE}

DURING the work described in the preceding pages, a watch was kept for any signs of disease, for the pathology of wild animals is very little known, and any information, however slight, may be of value. Although about a thousand tadpoles were examined, only one was found which could definitely be described as moribund from disease. Not one dead tadpole was found. The diseased tadpole had swellings resembling blisters. This may perhaps have been an infestation by a species of the trematode Euryhelmis, for an American species has been described (Ameel, I938) as having cercariae that penetrate the skin of tadpoles, causing blisters, the cysts being later found in the swollen areas. The definitive host is the mink, which of course does not occur in the area, but European species infest polecats (Joyeux et al., 1934) and are common in tadpoles as the intermediate hosts. Polecats are almost certainly absent from the area, but ferrets may very possibly have been taken along these banks and ditches.

Some exceptionally small tadpoles were examined for blood parasites, without result. Whether this short record of disease in tadpoles indicates that they are usually healthy is doubtful, for dead animals in a pond are soon disposed of by the other animals, including other tadpoles. It is quite common to find the labial teeth of tadpoles in the gut. I am uncertain whether in some cases these may not be the tadpole's own teeth, swallowed when they become detached, but on one occasion I found a tadpole's beak and these are certainly not detachable. This gap in information is most regrettable, but quite the usual thing in ecology (see Lack, I954, pp. I52 and I67).

The tadpole carries many parasites that do not seem to cause disease. Among the Protozoa, large numbers of Opalina are always found in the intestines, and there is usually Nyctotherus as well, but Wenyon (1926) does not consider these as pathogens.

Metazoan parasites are common. For example, small trematodes occurred in the intestines of tadpoles from Dagger Lane, but not elsewhere, and in 1947 there were nematodes as well. Nematodes 
were also found at Green Strect. Tadpoles from Hospital Pond had in one year the spherical cysts of the metacercariac of another trematode, either loose in the body cavity or attached to the mesenteries.

There is, however, another parasite that deserves more attention, because it is by far the largest, it is common, it has provided by its investigation some unexpected light on the life history of the tadpole itself, and it is of classical importance in parasitology.

\section{Polystoma integerrimum}

The material for this investigation (Savage, I949) was the same collection of tadpoles that served for the work on growth rates. It was not a study of the parasite in isolation, but was analogous to the reports of a Medical Officer of Health when he describes the course of an epidemic of typhoid in his district. In such a case, he does not treat the subject as a bacteriologist would, nor as a physician-it is the course of the epidemic that takes his attention. The work now to be described depends on the examination of about a thousand tadpoles, containing about four thousand parasites. Eight epizootics in five ponds were studied.

The life history of this parasite was studied by Zeller (1872, I876) and by Gallien (1935). The eggs of the mature fluke, which inhabits the bladder of the adult frog, are voided with the urine into the water of the pond when the frogs are spawning. The eggs of the trematode take longer to hatch than those of the frog, so that larval flukes find the tadpoles already at the active stage of their lives. The larvae swim rapidly by means of cilia, and enter the tadpoles by swimming or creeping through the spiracle. Once in the gill chamber, they attach themselves to the gills or to other parts and there develop in either of two distinct ways. If the tadpole is fairly advanced in development, the larvae change little although some differentiation does occur. At the time of metamorphosis, they migrate through the alimentary canal to the newly formed bladder of the young frog, and there reach maturity in about three years. If, however, the tadpole is young, the parasites may begin to grow so rapidly that changes are perceptible in a few hours. They develop into neotenic larvae, smaller and structurally different from the adults, but capable of laying self-fertilized eggs after a few weeks of growth. These eggs are passed out of the gill chamber into the pond and hatch after some weeks into larvae identical in appearance to the larvae that were the progeny of the 
mature fluke. These larvae enter the tadpoles in the same way, and at metamorphosis travel to the bladder with any undeveloped larvac. They never give rise to any neotenic forms. The neotenic larvae die and are expelled either in July or at metamorphosis if this is earlier.

\section{Nomenclature}

Five kinds of larvae are involved in these investigations-frog larvae, and four kinds of trematode larvae. To prevent confusions, I refer to the frog larvae, as usual, as tadpoles, and to the neotenic larvae as simply neotenics. This leaves the term "larvae" for the small forms. If these are the progeny of the mature fluke that lives in the bladder, they are called "primary larvae." There are two broods of these. The progeny of the neotenics are called "secondary larvae." There are no morphological differences between the primary larvae and the secondary, but if the course of the epizootic is followed it is usually clear which kind is contributing to the total infestation.

Nearly all the work on the tadpoles so far described has been carried out in a small part of south-east England, and over a period of only four years. There is no reason to suspect that the results I have reported are not typical, but it would be interesting to have some wider confirmation. $P$. integerrimum has confirmed the direct observations.

Fig. 20 shows the course of the epizootic in Upper Parkfield Pond in 1948. The first collections, on roth and 2oth April contained no polystomes. The first eggs hatched in the following week, so that on 27 th, large numbers of parasites were present, and some had already transformed themselves into neotenics. On I2th May, the numbers of both kinds had much diminished, because the parasites live in a precarious position, where the rushing water in the gill chamber is liable to carry them away. At about this time, however, the second brood of larvae appear and, on 28th May, the numbers of primary larvae reached a new peak, but the neotenics were not numerous. The numbers of both types then fell to a new low point on Igth June. A slight rise then took place, probably due to the emergence of secondary larvae. This is much better shown in the other graphs, which depict the state of affairs in ponds in which metamorphosis is delayed until July or August. Fig. 2I is an example. In this pond, Lower Parkfield I947, as will be recalled, there was an enormous number of tadpoles. There were so many, in fact, that the parasites distributed themselves over so many hosts that the average number in each was always low. 
On I3th August there was a relatively large peak, which must have been due to secondary larvac, for by this time all the primary larvae would have found hosts or have died. Fig. 22 is an extreme example of the importance of secondary infestation in late-metamorphosing

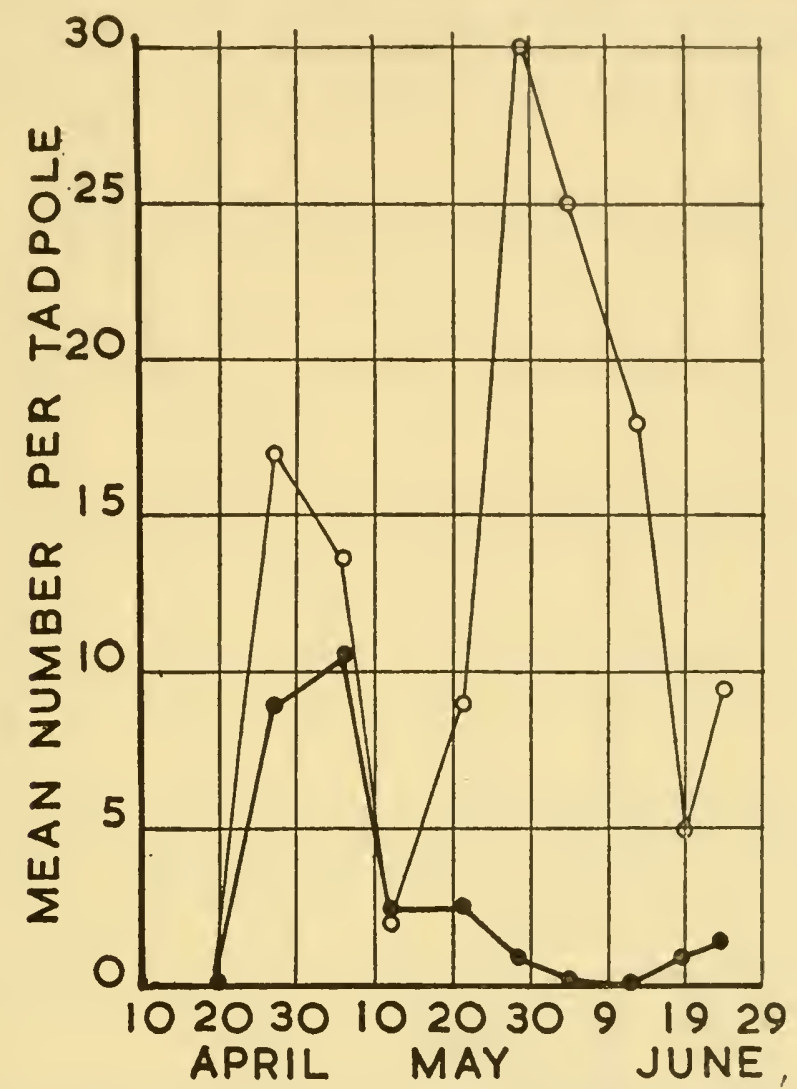

FIG. 20. Mean Numbers of Polystoma per Tadpole in Upper Parkficld Pond, I947

The black dots and solid line indicate neotenics, the open circles and thin line the larvae. Note the two larval peaks and some sign of a third. Note also that the scale of this diagram is different from Figs. 2I and 22, because the parasites were far more numerous than in the other cases.

tadpoles. The infestation in this pond, Dagger Lane 1947, was so low early in the season that none were found until I6th June, but, during July, enough secondary larvae had arrived to give a moderate infestation. Since, however, there were by then not many tadpoles, the total number of infested little frogs must have been very small.

I think that these graphs and others in the references cited show that the complicated life history of the parasite is an adaptation to the wide differences in the time of metamorphosis which I have already described 
from direct observations. It is only when metamorphosis takes place in late July or August that the neotenic cycle is any use at all. If the tadpoles metamorphose in June, as they sometimes do, the secondary larvae must swim vainly in the pond and die without finding a host.

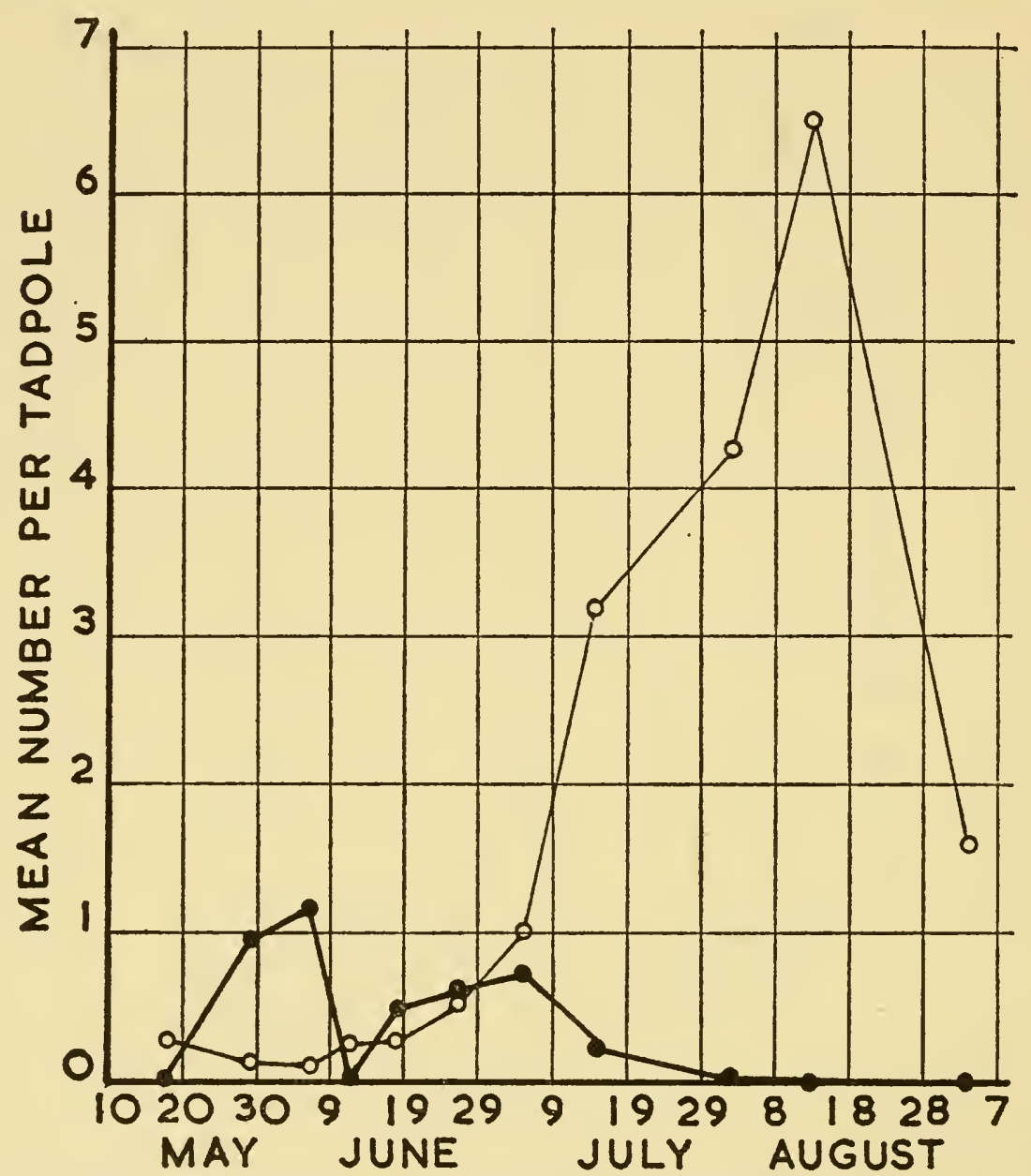

FIG. 2I. Mean Numbers of Polystoma per Tadpole in Lower Parkfield Pond, I947

In this pond, with a very large number of tadpoles surviving the first few weeks, the infestation was low at first. Metamorphosis was delayed, and a large influx of secondary larvae took place in August.

On the other hand, when metamorphosis is late, the losses from the gill chamber are so large that in these ponds there would be few primary larvae left. The neotenic cycle then provides a means of injecting a supply of larvae into the tadpole population just as the original lot are disappearing. It now seems certain that the wide variations in dates of metamorphosis that I reported are so much part of the normal life of 
tadpoles that the life history of the parasite has had corresponding modifications stamped upon it through the ages. I feel confident that similar differences must exist widely.

The numbers of parasites are distributed in a curious way. A tadpole usually has either very few parasites, or else very many, intermediate values being much rarer than would be expected from a random distribution (Chapter Io, Appendix I b). Moreover, there is no

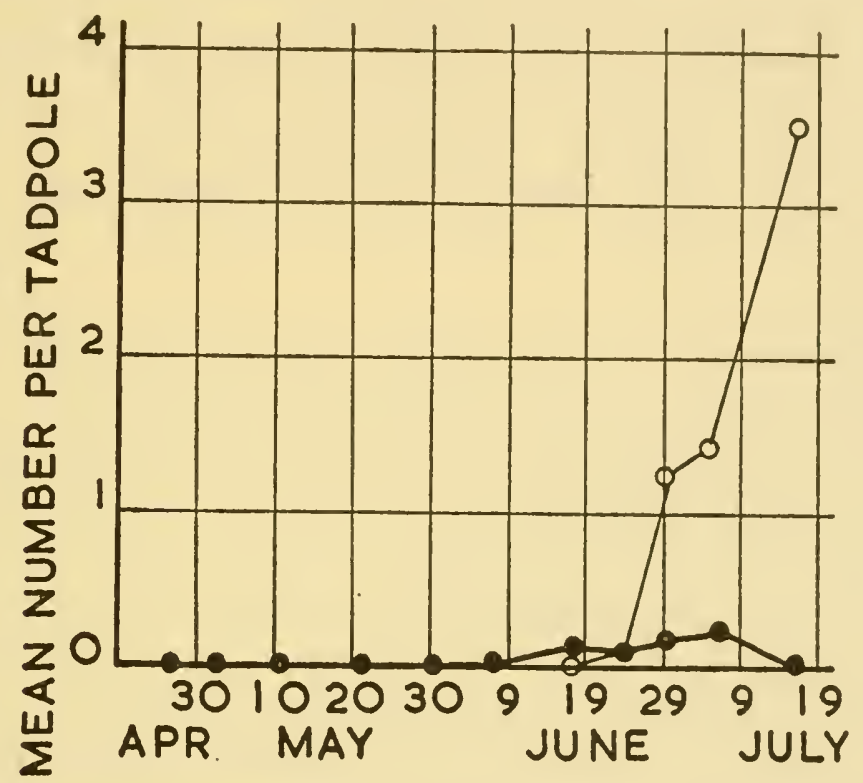

Fig. 22. Mean Numbers of Polystoma per Tadpole in Dagger Lane Pond, 1948

Infestation was very low at first. Metamorphosis was rather late, but the few neotenics evidently gave rise to enough larvae to infest the tadpoles in July.

relation between the size of the tadpoles and infestation, a fact that disposes of the idea that the parasites, even the neotenics, are harmful (Chapter Io, Appendix I c). They probably live on mucus and debris, and, if the tadpole has an operculum more transparent than usual, the neotenic provides the exceptional spectacle of an undisturbed internal parasite at work. In the light of the microscope lamp, the tadpole being held upside down in water, it can be seen ceaselessly grazing on the internal surfaces of the operculum, its eyes shining like motor-car headlights.

$P$. integerrimum lays fewer eggs than its host. This is a remarkable achievement for a parasite that must die if its host dies. The death rate 
of such a parasite, if it lives all the time in the animal, must be greater than that of its host, for to its own causes of death must be added those of its host. The existence of the neotenic, which is a multiplying stage, cannot explain the paradox, for this phase is only effective in late tadpoles, and only needed because so many larvae are lost in the protracted life of the tadpole. The probable explanation is that the most dangerous stage of tadpole life is the first few weeks. In this period, the trematode eggs are lying, comparatively safe, at the bottom of the pond, and only hatch to infest the hosts when the worst of the risks are over. This is another point at which the life history of the parasite confirms the observations on the tadpoles themselves.

I close this short account of epizootics of $P$. integerrimum with some unpublished observations on the factors causing the transformation into neotenics.

It is known from the work of Zeller and of Gallien that this transformation has some connexion with the age of the tadpole when it is first infested. The phenomenon as described by Gallien himself was not so sharp as the brief derivative accounts in various textbooks make it appear, nor did Gallien say that the parasites attach themselves to the external gills. But he did use the presence of external gills as an indication of the stage of development of the tadpoles in his experiments. In my field observations, only one abnormally small and undeveloped tadpole was found infested at this early stage. In every other case, the tadpoles were well past this stage before the first of the parasites appeared, and yet many neotenics resulted. If Gallien's original results are examined, it is clear that he explicitly and fully described similar transformations, but in the laboratory these were exceptions. In the field, on the contrary, they are the rule, and infestations at the age of the external gill stage occur, if at all, as a rare abnormality. This shows the importance of distinguishing between laboratory experiments and observations based on events in the field.

Since the hypothesis that age was the important factor seemed not to be quite right, I supposed that the sex of the frog harbouring the mature fluke was important. Female frogs are later arriving at the ponds than males, so that the eggs of the parasites that they contain would hatch later. If the parasites from male frogs became neotenics, but those from females did not, an explanation consistent with the older observations might appear. I therefore harvested the eggs of adult parasites from the two sexes of frogs separately, and by retarding 
the growth of the tadpoles by refrigeration was able to produce parasites and tadpoles at the external gill stage simultaneously (the fact that I had to refrigerate confirms that the parasites do not normally hatch when the tadpoles are at the external gill stage). The little flukes do not accept tadpoles of this age as hosts, but alight, make a few exploratory movements, and at once take off into the water to resume their active swimming. Not until the gills are becoming reduced do they remain on the tadpoles, and even then, do not attempt to go near the gills, but settle for some days anywhere on the tadpole. Pigmentation takes place during this time, and conversion to neotenics was apparently proceeding. Unfortunately for the hypothesis, parasites from both sexes of frog behaved in the same way!

\section{Predators}

It is generally stated that tadpoles are eaten by many of the animals in a pond. This statement is probably true, but nothing approaching a detailed account appears to exist. In ecology, one cannot accept as evidence the fact that, in an aquarium, the larvae of water bectles eat tadpoles, because in a pond it might be that the two species live in different places, and never meet. I do not think that this is so, but the example shows the problems that beset the ecologist when he trics to replace guess-work by observation. Because I have seen it happen in a pond, I know that the larvae of dragon flies (Odonata) seize passing tadpoles. Animals are under observation for such a small part of their lives that even the two instances that $I$ have seen must indicate that this often happens, and these insects may be one of the important predators. I think there must be many others in order to explain the disappearance of 99-100 per cent of the whole population. In Redwell Wood Pond, so small and shallow that I could wade all over it, and with water so clear that I could see everything, the tadpoles disappeared steadily over several weeks, until none were left, but I could never see why. I have no properly founded explanation, but I think some large predator such as visiting ducks or snakes must have been responsible. Most of the animals in a pond are small, and it is difficult to see in them a large enough cause of such wholesale destruction of animals that in their later stages are among the largest in the pond.

Blair (1927) states that in the New Forest, young medicinal lecches, Hirudo medicinalis, kill many frogs and tadpoles, which he found dead with the characteristic marks upon them. Carpenter (1953) records the 
massive attack on tadpoles of $R$. p. pretiosa by leeches, so that this predator must be considered seriously, although I have never seen any such attacks myself.

In this chapter, I cannot deal with the whole question of the mortality of the species, adults and tadpoles together, but must defer many questions on the relations between abundance and limiting factors until I have described the lives of the adult frogs.

\section{REFERENCES}

Ameel, D. J. (1938) J. Parasit., 24, 219-24.

BlaIr, W. N. (I927) Proc. zool. Soc. Lond., 2, 999-1002.

Carpenter, C. C. (I953) Herpetologica, 9, 77-8.

Gallien, L. (I935) Trav. Sta. zool. Wimereux, I2, I-I8I.

Joyeux, C., Baer, J. G. and Carriere, P. (I934) C.R. Acad. Sci., Paris, I99, I067-8.

Lack, D. (1954) The Natural Regulation of Animal Numbers (Clarendon Press, Oxford).

Savage, R. M. (1949) Proc. zool. Soc., Lond., I20, No. I, I 5-37.

Wenyon, C. M. (I926) Protozoology (Baillière, Tindall \& Cox, London).

ZeLLER, E. (I872) Z. wiss. zool., 22, I-39.

ZeLLER, E. (1876) Z. wiss. zool., 27, 238-74. 


\section{Chapter 5}

\section{THE LIFE OF THE JUVENILE FROG}

IN this chapter, I have the rather difficult task of dealing with a phase of this animal's life that is very little known, namely, the stage that begins with metamorphosis and ends with sexual maturity.

\section{Metamorphosis}

This is a well-worn theme in its embryological and physiological aspects, but for the ecologist there is little information. In some species, for example B. bufo (Savage, 1952) the tadpoles collect in a large aggregation at the bottom of the pond, shortly before they metamorphose. The function of this habit is unknown, and it does not seem to happen in $R$. temporaria, which seems simply to remain near the edges of the pond until it is sufficiently developed to emerge from the water. I have already recorded a case of heavy mortality at this time, apparently due to drowning, just as can be seen in captivity if the animals are kept in a vessel with sides too steep for them to climb. It is remarkable that frogs of this age seem to drown so easily. It is well known that the cutaneous respiration of frogs is sufficient to maintain life, provided that the water in which the frogs are immersed is well oxygenated. Metamorphosis in nature occurs in the hot weather, and perhaps this is the reason for the dependence of the young frogs upon aerial respiration.

\section{Dispersal}

There are numerous reports of immense numbers of little frogs leaving ponds at this time, and, indeed, almost supernatural explanations, such as whirlwinds or waterspouts in regions where these are extremely rare, have been advanced as explanations. All that is necessary to explain this phenomenon is an exceptionally large survival of tadpoles to metamorphosis. The original population of tadpoles is sufficient to give rise to astonishing numbers, and the reason why this is not more often seen is that the death rate of the tadpoles is usually too high. The phenomenon itself is not important-we should very 
much like to know the reasons for the survival of so many tadpoles, and the effects of the excessive numbers of little frogs on their ultimate fate, but this kind of thing does not usually interest the reporters, who are content to marvel.

There is no evidence for any large difference in habits between the juvenile frogs and the adults, except at the breeding season. In some other species, there are such differences. For example (Lantz), the young Natterjack Toad, Bufo calamita, is diurnal and runs about even in bright sunshine. Bragg (1940) found young Bufo woodhousii to be diurnal and Martof (1953) found the same of Rana clamitans. Young treefrogs, Hyla arborea, were said by Boulenger (I898) to live in the grass, and I thought this to be an example of a difference in habits between young and adults until, happening to go into a field of long grass in France, I found many young treefrogs there, just as Boulenger had said, in the grass. But when I saw that each was clinging to a grass stem in exactly the same attitude as the adults adopt when on bushes or trees, I realized that the little frogs were not living, as I had imagined, as if they were R. temporaria, but had merely adapted the habits of their own species by changing the scale. This is probably made necessary in order to avoid the less humid regions of the tree tops, where such small animals would probably dry up during the day. $R$. temporaria, adult or young, lives largely in the grass, and has no need to change its habits in this way.

It is possible that this phase is one of wide dispersal. Adult frogs must make an annual journey to the ponds to breed. For two or three seasons, the young frogs are freed from this necessity, and could in time cross territory with no ponds and thus populate a new area, if at the end they found ponds in time for their maturity. But we really know very little.

\section{Length of the Juvenile Stage}

Smith (I95I) considers that sexual maturity is generally reached at the age of three, although sometimes a year earlier. This is an important point, with a bearing upon the general problem of predation and abundance, but a further discussion of it belongs to the next chapter.

The shortness of this chapter emphasizes the paucity of the information. Perhaps there is nothing more to know, but how often in science has such a view been shown to be false! 


\section{REFERENCES}

Boulenger, G. A. (1 897-8) The Tailless Batracians of Europe(Roy. Soc., London). Bragg, A. N. (1940) Amer. Midl. Nat., 24, No. 2, 306-21.

LANTz, L. A. Personal conversation.

Martof, B. (1953) Ecology, 34, No. I, I65-7I.

Savage, R. M. (1952) Proc. zool. Soc. Lond., 122, 467-5I4.

Smith, M. A. (I95I) The British Amphibians and Reptiles (Collins, London). 


\section{Chapter 6}

\section{DISTRIBUTION AND ABUNDANCE OF THE "TEMPORARY FROG"}

At this point in the story, the theme changes suddenly. We are now to deal with the lives of the adult frogs. Before I pass on to the details, I feel that I must refer to a dilemma that confronts many scientific authors. Failure to recognize its existence can have serious effects on the understanding that others may have of what it is that the author is trying to convey.

The duty of a scientific author is not only to present the facts. $\mathrm{He}$ must also put forward hypotheses that have arisen in his mind, so that he and others can discuss and consider whether the hypotheses are reasonably consistent with the facts. He may also feel it his task to speculate-that is to extrapolate from the facts, if by this means he can advance his subject by stimulating thought. But he must do all he can to distinguish between fact and hypothesis, and this is where the difficulty arises. There seems to be a tendency on the part of readers to rivet fact to hypothesis more firmly than the author would wish. It is a common thing for later facts to show that a hypothesis is wrong. This is not a disaster, although it may be disappointing, for this process of acceptance and rejection is normal to science. If, however, the facts have been so firmly riveted to the hypothesis that both are rejected together, much harm can result, for, if the facts are correct, any later hypothesis must be consistent with them, as well as with the new facts. In a very different but also very complicated field, Biggs and Macfarlane (195I) have discussed this point, and have shown that this process of riveting fact to hypothesis, not by the author but by others, has to their knowledge retarded advances by many years. They suggest that authors should not end their papers with a hypothesis, but should put it at the beginning. I have adopted a literary device with the same object. In scientific conversation and discussions, speakers alternate between the first person and the third, dropping naturally into the first when they are putting forward their own ideas and do not wish to claim that they are proved. An excessive use of the third person may give an impression of certainty far from the author's 
intentions. In this book, expressions such as "I think" mean just what they mean in conversation: what follows has been carefully considered but I do not expect anyone to believe that I have proved the point. I hope that they will not follow disbelief of the hypothesis by rejecting the facts on which the hypothesis is based.

Walking across the ficlds from one pond to another in the early thirtics, I could not reconcile what I saw with the current hypotheses about migration, pond-finding or the relation between the weather and the activitics of the frogs. I came to the conclusion that, in the study of frogs, it was the events in the ponds rather than those in the frogs that determined the actions of the animals. I felt that the animals were for much of the time responding to changes in the environment, but not to changes in their own physiology, except in the limited sense that, unless the animal is in a suitable physiological condition, it cannot respond.

In detail, the hypothesis that seemed to me to fit the facts (Savage, I935) was that the frogs responded to some change or difference in the algal population of the ponds, so that the effects of physical factors such as the weather were indirect. At this stage, the reasons for this hypothesis may seem obscure, but I hope that, as the tale unfolds to its end, things will become clearer. I therefore now give merely a very short summary of the ideas that led to the hypothesis-

I. The explosive nature of breeding in this species; all frogs brecding in a pond do so within a few days of each other.

2. The wide differences in the date of spawning between different ponds in the same area.

3. An apparent influence of rain in accelerating spawning.

4. The impossibility of accounting for the selection of ponds by any obvious character.

5. The precision of migration, so that the frogs seem to know where the ponds are long before they could see them.

6. The parallelisms with the known properties of algac, as follows-

7. Algae exhibit phases of growth or development often of an explosive character.

8. In a small area scarcely any two ponds have the same algal flora. The algal population is highly specific.

9. Algal growth and development are under the influence of the weather, especially the rainfall, and are strongly related to the geology and water composition. Algal events are often simultaneous in one pond, but occur on different dates in different ponds. 
Io. Many algae have characteristic smells, perceptible even to the dull human senses at a distance from a pond. It follows that the smell of a pond is specific, in the sense that it is something not found in nature except in a pond, and any particular smell is found only in a few ponds out of many that may be in the area, and then only at certain times. It is detectable at a distance.

At the time (1935) I first stated this hypothesis, the evidence for it was not very strong, but at least it was an improvement on the others existing at the time. It is now my intention to continue with the description of the life of the frog, leaving it to the readers, with occasional reminders from me, to decide whether the later evidence confirms or conflicts with the original hypothesis. If they decide that it conflicts, then I hope that any alternative suggestions that they can think of will be at least as good a fit. They must certainly not be at variance with the facts of the field.

\section{Distribution}

Distribution is a term with many shades of meaning. Systematists use it to describe the areas within which the species may be found, even if these are as large as whole continents. The ecologist is interested in finer divisions, such as the different geological regions within a country, or even in the way a species distributes itself between two ponds in the same field. Ultimately, it may well be that the large area is merely the sum of many such small ones, fitted together as a mosaic, so that a country contains frogs because it contains ponds that provide suitable living conditions for the frogs. I therefore begin with an account of the distribution of frog-ponds in a small area (Savage, 1939).

The area lay on the borders of Middlesex and Hertfordshire, and covered about eighty square miles. Within this area, 92 ponds were kept under observation over a period of ten years. None were observed for the whole of this time, for most of the observations were made between 1934 and 1938, although less systematic observations were maintained for another twenty years afterwards, and some of the ponds were known for twenty years before. No attempt was made to include every pond, although the most intensively studied area was thoroughly searched and probably none were missed. In the other parts, accessibility was the main reason for choosing them. There is no good reason for supposing that accessibility was related to the ecology of the ponds, so that the sample could be regarded as typical, even if it 
TABLE I

SPAWN FOUND IN YEAR OF OBSERVATION

$X$ = Spawn found: $O=$ No spawn found: $-=$ No obscrvation

\begin{tabular}{|c|c|c|c|c|c|c|c|c|c|c|}
\hline Pond Name & I929 & 1930 & I93I & I932 & 1933 & I934 & 1935 & 1936 & 1937 & 1938 \\
\hline Upper Ridge Hill & - & 一 & 一 & - & - & - & - & $x$ & O & $x$ \\
\hline Lower Ridge Hill & - & - & - & - & - & - & - & O & - & $x$ \\
\hline Potters Bar Garden & - & - & - & - & - & $x$ & $x$ & $x$ & $x$ & $x$ \\
\hline Potters Bar Church & - & - & 一 & - & - & - & - & - & $\mathrm{O}$ & O \\
\hline Potters Bar Park . & - & - & - & 一 & - & - & - & 一 & 0 & 0 \\
\hline Grassfield House . & - & - & - & - & - & - & - & 0 & $\mathrm{O}$ & 一 \\
\hline Potters Bar Parkfield & - & - & - & - & 一 & - & $\times$ & - & $\times$ & $x$ \\
\hline Catherine Bourne & - & - & - & - & $一$ & - & - & $x$ & $x$ & $x$ \\
\hline Rabley Park Lodge & - & - & - & - & 一 & - & - & $\mathrm{O}$ & 0 & O \\
\hline Green Street, N. . & - & 一 & 一 & - & - & - & - & 0 & 0 & O \\
\hline Green Street, NE. & - & 一 & - & - & - & - & - & 0 & 0 & $\mathrm{O}$ \\
\hline Green Street, SW. & - & - & - & - & - & - & - & 0 & O & O \\
\hline Green Street Large & 一 & - & 一 & - & - & - & - & $x$ & $x$ & $x$ \\
\hline Green Street Footpath & - & - & - & - & - & - & - & - & 0 & 0 \\
\hline Green Street Lyndhurst. & - & - & - & - & - & - & - & O & $\bigcirc$ & $x$ \\
\hline Stag Hill . & - & - & - & - & - & - & - & $\bigcirc$ & $\bigcirc$ & O \\
\hline Battlers Green L. . & - & - & - & - & - & - & - & 0 & 0 & 0 \\
\hline Battlers Green Star & - & - & - & - & - & - & - & 0 & 0 & 0 \\
\hline Battlers Green Tree & - & - & - & - & 一 & - & - & $x$ & $x$ & $x$ \\
\hline Battlers Green Marsh & - & - & - & - & - & - & - & 0 . & $x$ & $x$ \\
\hline Bluebell Wood . & - & - & 一 & $x$ & - & $x$ & 一 & 0 & $x$ & 0 \\
\hline Medburn . . & - & - & - & 一 & - & 0 & - & ○ & 0 & 0 \\
\hline Pylons & 一 & - & - & - & - & 0 & $\bigcirc$ & 0 & - & 0 \\
\hline Dagger Lane & $x$ & - & - & - & - & 0 & 0 & $x$ & 0 & $x$ \\
\hline West Railway West & - & - & - & $x$ & - & 0 & - & $x$ & $x$ & $x$ \\
\hline West Railway & $x$ & 一 & - & 0 & - & 0 & - & $\bigcirc$ & O & 0 \\
\hline East Railway & - & 一 & - & $x$ & - & $x$ & - & 0 & O & $x$ \\
\hline Letchmore Heath, S. & 0 & 一 & - & - & - & - & - & - & 0 & O \\
\hline Letchmore Village & - & - & 一 & - & 一 & - & - & 0 & O & O \\
\hline Aldenham School & - & - & 一 & 一 & - & - & 一 & 0 & 0 & - \\
\hline Letchmore Hilltop & 0 & - & - & - & 一 & - & 一 & - & - & 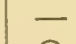 \\
\hline Elstree, Two Bush & - & - & - & - & - & 0 & - & 0 & - & 0 \\
\hline Elstree, Hedge & - & - & - & - & - & $\bigcirc$ & 一 & 0 & $\mathrm{O}$ & O \\
\hline Elstree Circular . & 一 & 一 & - & - & - & $\bigcirc$ & - & 0 & 0 & O \\
\hline Folly Farm Stream & 一 & 一 & $x$ & $x$ & $x$ & $x$ & $x$ & $\bigcirc$ & $x$ & $x$ \\
\hline Elstree, One Oak. & - & - & - & 一 & 一 & 0 & - & 0 & O & O \\
\hline Elstree, Two Fence & - & - & - & 一 & 一 & 0 & 一 & O & O & O \\
\hline Elstree, Long & - & - & - & - & 一 & $\bigcirc$ & - & O & $\bigcirc$ & O \\
\hline Elstree, Centre Field & - & - & - & $\rightarrow$ & - & 0 & - & 0 & $\bigcirc$ & $\mathrm{O}$ \\
\hline Elstree, Willow Tree & 一 & - & - & - & 一 & 0 & - & $\bigcirc$ & 0 & $\mathrm{O}$ \\
\hline Elstree, Enclosure. & - & - & - & $x$ & 一 & 0 & - & $\bigcirc$ & 一 & 0 \\
\hline Queensbury Lodge & 0 & - & 一 & 一 & 一 & 一 & 一 & $\overline{0}$ & - & - \\
\hline Rowley Green Gorse & - & - & - & 一 & - & 一 & 一 & 0 & & $\begin{array}{l}x \\
x\end{array}$ \\
\hline Rowley Green, S. & 一 & - & - & 一 & 一 & 一 & 一 & 0 & & $x$ \\
\hline Boys Hill, E. & - & - & - & - & - & 一 & 一 & $\bigcirc$ & 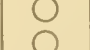 & ก \\
\hline Boys Hill Central. & - & - & - & - & - & 一 & - & 0 & 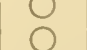 & ค \\
\hline Boys Hill Holly Bush & - & - & - & 一 & 一 & 一 & 二 & 0 & 0 & $C$ \\
\hline Arkley Stile. & 一 & - & - & - & - & 一 & - & $x$ & 0 & $\mathrm{C}$ \\
\hline Arkley Brickpit . & - & - & - & - & - & $\overline{1}$ & $\overline{0}$ & $\hat{0}$ & 0 & 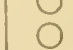 \\
\hline Bottom Corner . & - & - & - & - & 一 & 0 & $\underline{0}$ & 0 & 0 & 0 \\
\hline Gladwyns Farm, W. & - & - & - & - & - & 一 & - & & & \\
\hline
\end{tabular}


TABLE I (continued)

\begin{tabular}{|c|c|c|c|c|c|c|c|c|c|c|}
\hline Pond Name & 1929 & I930 & I93 I & 1932 & I933 & I934 & I935 & I936 & I937 & 1938 \\
\hline Gladwyns Farm Central & 一 & - & - & - & 一 & 一 & - & 0 & 0 & 0 \\
\hline Gladwyns Farm, E. & 一 & 一 & - & 一 & 一 & - & - & $\bigcirc$ & $\bigcirc$ & $\bigcirc$ \\
\hline Coppice & - & 一 & 一 & $\longrightarrow$ & - & - & - & $\bigcirc$ & $\bigcirc$ & 0 \\
\hline Lower St. Edmunds & - & - & - & - & - & - & - & 0 & 0 & 0 \\
\hline Upper St. Edmunds & $一$ & - & - & - & - & - & - & $\bigcirc$ & $\bigcirc$ & 0 \\
\hline Overflow & 一 & - & - & - & - & 0 & $x$ & 0 & 0 & 0 \\
\hline Hibernating. & - & - & - & - & - & 0 & O & 0 & O & O \\
\hline Hendon Wood Lane, & & & & & & & & & & \\
\hline W. · $\cdot{ }^{\circ}$ & 一 & 一 & 一 & 一 & - & 一 & 一 & 0 & $\bigcirc$ & $\mathrm{O}$ \\
\hline Hendon Wood Lane, E. & 一 & 一 & 一 & 一 & 一 & $\overline{2}$ & $\overline{2}$ & $\bigcirc$ & $\bigcirc$ & $\bigcirc$ \\
\hline Ornamental. & - & 一 & - & - & 一 & $\bigcirc$ & $\bigcirc$ & $\bigcirc$ & 0 & 0 \\
\hline Drive . . & - & 一 & 一 & 一 & - & $\bigcirc$ & $\bigcirc$ & $\bigcirc$ & $\bigcirc$ & O \\
\hline Lily $\cdot \cdot \quad \cdot \quad$ & 一 & - & - & - & - & 0 & 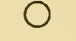 & $\bigcirc$ & $\bigcirc$ & O \\
\hline Upper Hyver Hall & - & - & 一 & - & 一 & - & - & $\bigcirc$ & $\bigcirc$ & O \\
\hline Lower Hyver Hall & - & - & - & 一 & 一 & - & 一 & O & 0 & O \\
\hline Hyver Willow Tree & - & - & - & - & - & 一 & - & O & 一 & 0 \\
\hline County Boundary & - & - & 一 & 一 & 一 & 一 & - & O & $\bigcirc$ & O \\
\hline Totteridge Village & - & - & 一 & - & - & - & - & 0 & $\bigcirc$ & O \\
\hline Oak Lodge : & 一 & 一 & - & - & - & - & - & 一 & 0 & 0 \\
\hline West Totteridge . & $x$ & $x$ & $x$ & $\times$ & $x$ & $x$ & $\times$ & $\bigcirc$ & - & - \\
\hline Middle Totteridge & - & 一 & 0 & 0 & 0 & $x$ & 0 & 0 & 0 & 0 \\
\hline Large Totteridge . & - & $x$ & $x$ & $x$ & $x$ & $x$ & $x$ & $x$ & $x$ & $x$ \\
\hline East Totteridge . & - & - & 一 & - & $x$ & $x$ & $x$ & O & $\bigcirc$ & 0 \\
\hline Hendon Park & - & - & - & - & - & - & - & $x$ & O & $x$ \\
\hline Hendon Park, E. . & - & - & 一 & - & - & 一 & 一 & $\bigcirc$ & 0 & 0 \\
\hline Nan Clark's Lane. & 一 & - & 一 & 一 & $x$ & $x$ & $x$ & 0 & 0 & - \\
\hline Ellern Mede Upper & - & - & - & - & O & $x$ & $x$ & 0 & 一 & 0 \\
\hline Ellern Mede Lower & - & 一 & - & - & - & O & - & - & 一 & 0 \\
\hline Holcombe Dale Upper & - & - & 一 & - & - & - & - & 0 & 0 & 0 \\
\hline Holcombe Dale Lower & - & 一 & 一 & 一 & 一 & 一 & 一 & 0 & 0 & 0 \\
\hline Holcombe Dale Holly & 一 & 一 & - & - & - & - & 一 & $\bigcirc$ & 0 & $x$ \\
\hline Keens . . . & - & 一 & 一 & 一 & $x$ & 0 & $\bigcirc$ & O & $\bigcirc$ & $\mathrm{O}$ \\
\hline Stanmore Pump . & - & - & 一 & 一 & - & - & 一 & 0 & $\bigcirc$ & $\mathrm{O}$ \\
\hline Stanmore Upper . & 一 & - & 一 & - & - & 一 & - & 0 & $\overline{0}$ & 0 \\
\hline Lower Ridgeway. & - & - & 一 & - & $x$ & $x$ & $x$ & 0 & $\bigcirc$ & 0 \\
\hline Churchyard. & 一 & 一 & 一 & $x$ & $x$ & $x$ & $\times$ & $x$ & $\bigcirc$ & O \\
\hline Upper Ridgeway. & 一 & - & 一 & $\times$ & $x$ & $x$ & 0 & $x$ & 0 & $x$ \\
\hline Pinner, Palmate Newt & 一 & - & $\times$ & - & - & - & - & - & 一 & $x$ \\
\hline Pinner, Willow . & 一 & 一 & 一 & - & - & 一 & - & - & - & $x$ \\
\hline Pinner, Rush & - & - & 一 & - & - & 一 & 一 & - & 一 & 0 \\
\hline Hatch End . & 一 & 一 & - & - & - & - & - & 一 & - & $x$ \\
\hline
\end{tabular}

did not conform to the statistical ideal of "random." Ponds that did not contain spawn were just as important as those that did, and the usual procedure was to walk across the fields observing every pond reasonably accessible.

It was unusual for a pond to have breeding frogs every year. In Table I, Large Totteridge is shown as having spawn in all the nine successive years of observation, but since that time frogs have deserted 
it, and I now know of no exception to the rule that frogs do not spawn in any pond every year. Ponds range from those in which spawn is almost always present to those in which it has never been scen, with all gradations in between.

It must not be thought that the choice of ponds by frogs is random. Fig. 23 is a map of the area, in which the popularity of ponds is shown against a background consisting of a gcological map. From this, it can be seen that there is a conspicuous association of popularity with geological formation, most of the popular ponds being on any formation except London Clay. The favoured formation is the Drift, such as Glacial Gravel and Pebble Gravel, but Reading Beds, Flood Plain Gravel and Alluvium are also used. The London Clay has many ponds and in the summer frogs live on it, and in the winter may hibernate there. When the time comes for them to lay their eggs, they leave it for the other formations. Chapter Io, Appendix I $d$, provides statistical evidence for the significance of the association.

This dislike of the London Clay is not absolute. The ponds there do sometimes have spawn, and in fact Dagger Lane is a London Clay pond, but it is not a frog-pond every year.

The proportion of ponds used by frogs varies from year to year. In I938, 22 ponds out of 86 observed contained spawn, but in 1937 only I I out of 78. In I958, I toured the area, visiting not only the familiar ponds, but many others, and found only two with spawn, one on Pebble Gravel and the other on Glacial Gravel.

The investigation included many analyses of the waters for the seven principal ions: calcium, magnesium, sodium, potassium, carbonate, sulphate and chloride. As might be expected there was a strong association between the geological formation and the composition of the water, but it also became apparent that ponds very near to one another might sometimes have water very different in composition. It is unusual for a London Clay pond to have water much different from the usual type, but the more pervious formations yielded many unexpected results: with them, it is quite difficult to guess from the position of the pond what the water will contain. Statistical analysis of the association of spawn with water-composition showed that the only ions having significant associations were potassium, phosphate, and to a lesser extent, carbonate. Frogs undoubtedly prefer ponds richer in potassium than the average for the district. This association was independent of the geology, for there was no significant association 


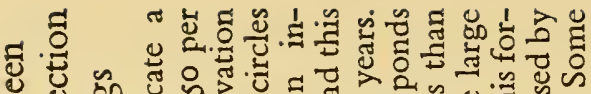

造

क $\dot{\infty} 0>$ क

N

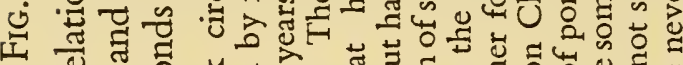

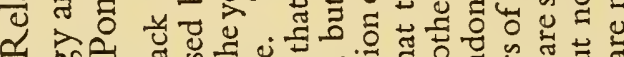

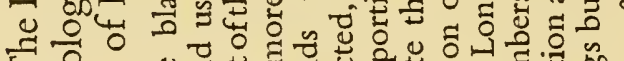

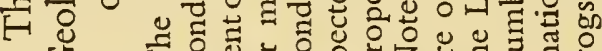

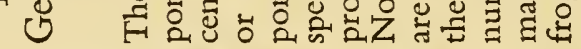

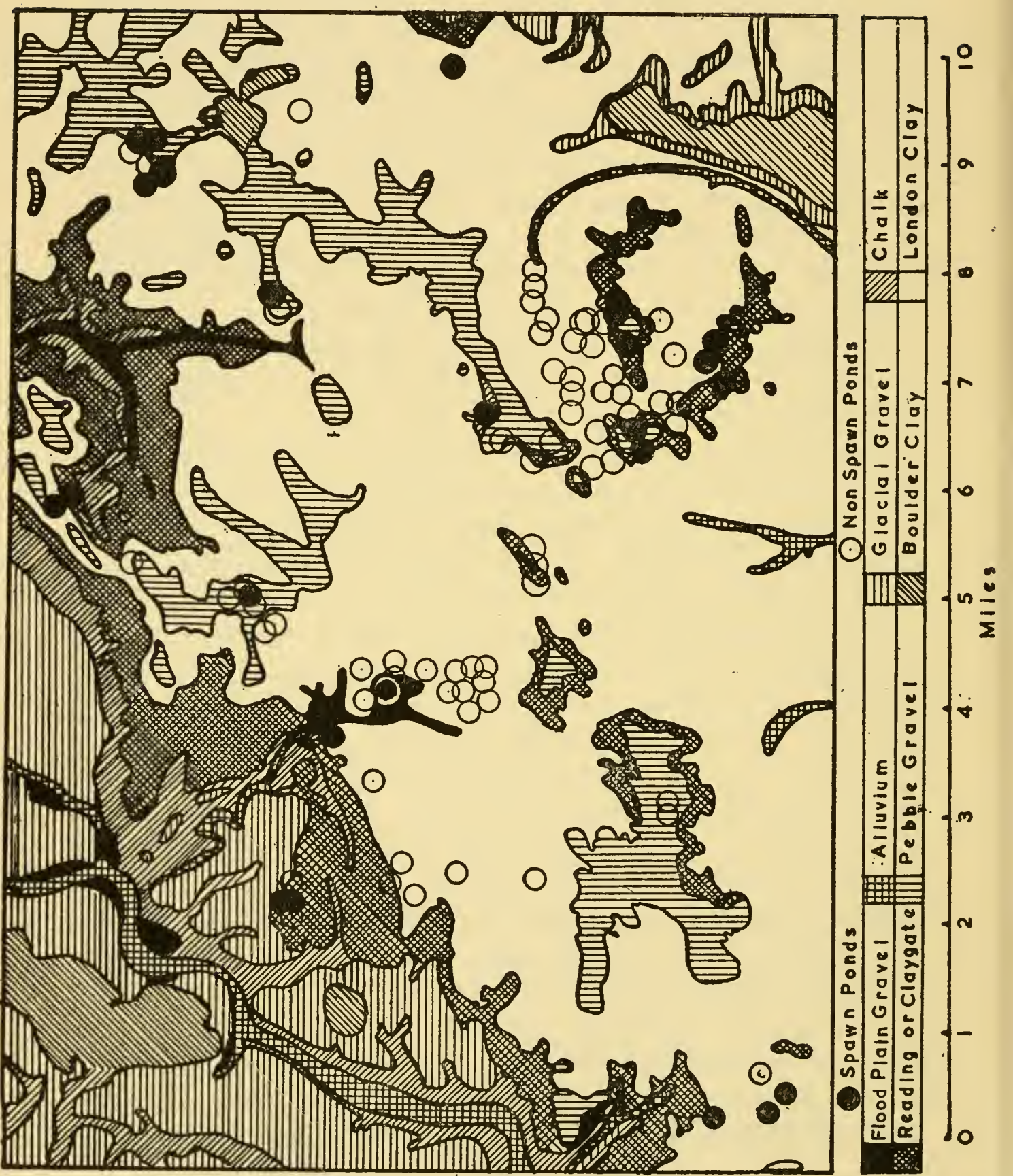


between potassium and geology. Carbonate was slightly associated with geology, so that the preference of the frogs for ponds high in carbonate was not so certain. Phosphate was not investigated at the same time nor in the same way, for instead of single samples of the water from a large number of ponds, weekly samples were taken from six non-spawn ponds and eight spawn ponds, from January to April. Phosphate is one of the plant nutrients that may become depleted in

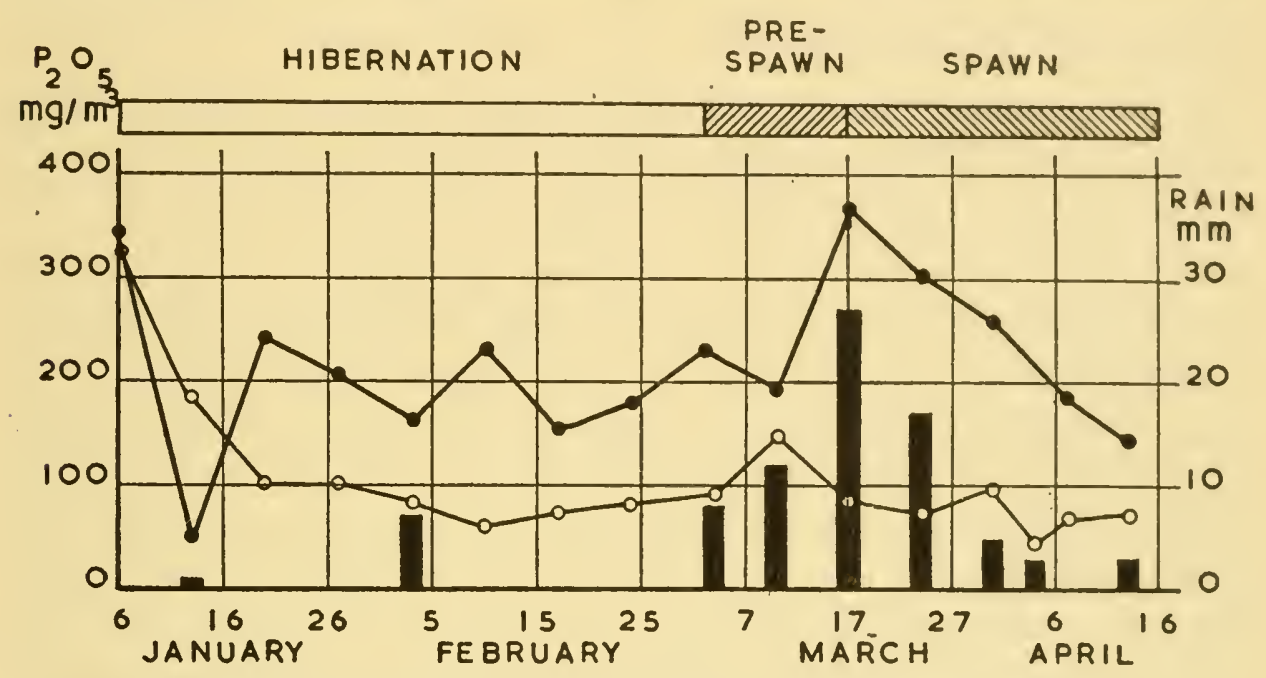

Fig. 24. The Course of Phosphate Concentration in Spawn Ponds and Non-spawn Ponds, from January to April

The first two points of the non-spawn ponds are from single records. The thick line and solid dots indicate the non-spawn ponds, the thin line and open dots the spawn ponds. The non-spawn level is about twice that of the spawn pond level. Note that the rain affects the non-spawn ponds more than the spawn ponds.

ponds where the plants are growing rapidly, and is replenished when rain washes it into the pond from the land. It is therefore interesting to note that it was just this reciprocal relation that was observed. Fig. 24 shows the results. The first two points for the non-spawn ponds may not be reliable, because they were based on only one pond, but at all other dates the values for the non-spawn ponds lie above those for the spawn ponds. Moreover, both curves tended downwards all through the dry January and February, and when rain fell in March, the phosphates, replenished by the run-off, rose more in the nonspawn ponds. After the middle of March, both tended downwards. This suggests that plant activity was higher in the spawn ponds, and it was, of course, these that tended to have high potassium. The result 
for 6th January for the spawn ponds is fully reliable, for it was based on samples from all of them, and it is therefore clear that these ponds do have high phosphate at an early date-it must be that it gets used up rapidly as the season advances. It is not certain whether there is a relation between phosphate and geology, for all these ponds lay on only two formations, and the sample was small. These results will be discussed further in Chapter 8 , for they have a bearing on the factors affecting the date of spawning. Detailed statistical findings are in Chapter Io, Appendix I $e$.

I do not believe that the chemistry of the ponds has a direct action on the frogs. The evidence for this lack of belief is complicated, and I cannot discuss it here. It will have attention later in Chapter 8.

It is easy to see that an extension of the principle of avoidance that I have suggested for the London Clay ponds might, if it were absolute instead of relative, result in some areas being entirely without frogs, even if the area was physically available to them. This does happen. For example, South Haven Peninsula, Dorset, has no frogs. A part of this very interesting area has been built up out of the sea during the last hundred years (Diver, 1933), and is still increasing. Another part, however, is ancient land, the Bagshot Beds. All the water in the area is fresh, and, indeed, with one minor exception, is very poor in saline constituents. B. bufo occurs, and so does the smallest British newt, $T$. helveticus, which breeds in almost every pool, both on the old and on the new land. Since the poorest traveller of all the British amphibia has colonized the area, it is impossible to believe that the area is without frogs merely because they have not had time to reach it. They occur on Grange Heath, only about eight miles away and with no intervening obstacles (Smith, 1938). In my view, the absence of frogs is explicable on the hypothesis that the water of South Haven Peninsula is not attractive to frogs.

There are other areas without frogs. For example, West Sedgemoor, all the ground above the 600 foot contour near Alnwick, Northumberland, parts of Gloucestershire have all been reported as being without frogs, and there are probably many such cases. In none are the frogs very far away, for Taylor (1948) recorded them from every county in England and Wales. On the other hand, Mr. C. Faris, writing from Ireland, said that frogs were so common in his area that he could not say for certain that any pond would not contain spawn.

Geological relations have been noted by other authors in other 
species. Gadow (1909) pointed out that Salamandra salamandra is not found on limestone formations. Noble and Noble (1923) showed that Hyla andersonii is found only in Sphagnum pools, which amounts to a geological or chemical connexion, for Sphagnum is only found in acid waters. Wright and Wright (1949) also point out that frogs are apparently affected by geological factors, and that the brecding ponds appear to be dependent on the nature of the surface waters of these areas.

In Chapter I I pointed out that the evidence existed showing that the species cannot live in areas where the spring temperatures are high. There seems hardly any limit to the cold it can stand, for in the Alps, it is found up to the snow line, and these Alpine frogs and tadpoles are unusually large. I suspect that this is an Alpine or northern species, living in the lowlands in England not quite under optimum conditions. Fig. I shows the distribution as far as it is known, and is largely drawn after Balcells (1956). It can be seen how far north the animal ranges. Many of the countries in which it is found, such as Poland and Finland, have severe winters. Those living in the mild climate of the British Isles must remind themselves that, in those countries, the frog lives in the winter deep under the snow, or at the bottom of ponds thickly covered with ice. They may also recall that the year when there were most tadpoles in the ponds followed a winter of almost continental severity.

The question of distribution is connected with that of abundance, for obviously, at the boundaries of the range, it is reasonable to expect that the species will become rare, and that, as one proceeds further, it will disappear altogether. But abundance has many other facets, and fluctuations in abundance have attracted the attention of many ecologists, not always with unanimous results.

\section{Fluctuations in Abundance}

Lack (1954), in the first book entirely devoted to this subject, has given many examples from birds and other animals, but does not include any amphibian. In reading his book, explicitly written to provoke discussion and criticism, I have been interested to compare and contrast the events he describes with those I know in the life of the frog. I find some features that seem to confirm his views, but others in which I must differ.

The fundamental basis of the theory put forward by Lack and his 
predecessors is that, provided the conditions remain the same, the population density of an animal is kept approximately constant by the operation of "density-dependent factors": that is, factors that cause the death rate to rise as the population rises, and to fall as it sinks. This, of course is the principle of many automatic regulators, such as thermostats. It is stated, moreover, that this is the only type of control that can ensure a balance. It is important to note that one of the premises on which the argument rests is that the numbers of an animal vary only within quite small limits, and that, even when some disturbance occurs, such as a hard winter, the original numbers are regained in a few seasons at the most. Lack also considers that the usual idea that reproductive rates are adapted to death rates is erroneous: it is the other way round, for he gives evidence to show that, in some birds, the reproductive rate is fixed by natural selection so that it is the most efficient rate. If, for example, more eggs than the average are laid, the number of young birds reared is not more, but less, because deaths from starvation are more numerous. It is my opinion, which I shall support with examples, that in the frog these premises are not always true. Regulating factors of the type described do occur, and may be very important, but instability to the point of extinction is characteristic of frog populations, and the disturbances are not shortlived, but may last for many years. Factors exist, I think, not dependent on density at all, and they may even be inversely density-dependent, so that they bear most severely when the population is smallest. Catastrophes, in a special as well as a general sense, are of common occurrence. It follows from this that I think that, under some conditions, reproductive rates have become adapted to death rates. It is quite possible that some of these differences are a matter of scale. Solomon (1949) has pointed out that whether a person takes the view that a population is stable or not depends very much on the time scale used by that person. Viewed over a century, a population may appear stable, but from one year to another, it appears unstable. Much the same can be said in terms of space. The habitats of an animal are arranged as a mosaic. The population of frogs in south-east England, or in Hertfordshire, may appear stable from one year to another, but the population of a pond within this area may rise from nothing to a very large number and then decline again, and so appear violently unstable to anyone observing it. It is necessary to be quite detailed in definitions. 
If, now, we take events in their natural order, and begin with the tadpoles in a pond, then it seems clear that in Lower Parkfield, and for much of the time at Dagger Lane in 1947, we have just the kind of events that Lack finds in most birds. The population of tadpoles was too large for the ponds, and in one, led to such disasters that the final effect was not a larger number of frogs, but almost certainly a smaller. There is very good evidence that food shortages occurred in many of the ponds and must have provided a density-dependent factor limiting the population. In other ponds, I feel sure that predation was responsible for the catastrophic decline in numbers, often reaching complete extinction. The assumption that predation is a density-dependent factor has, I think, often been made in too facile a manner. If the predators were dragon-fly larvae, I am prepared to believe that, when the numbers of tadpoles are large in one year, so many dragon-flies survive that next year, the population of tadpoles meets with increasing predation and so declines. But I cannot accept that this argument applies to ducks. A pair of ducks could eat all the tadpoles in a pond in a few days, and probably this often happens, but surely it cannot be argued that the population of ducks next year is larger because of this fleeting episode in the life of the ducks. Ducks are very probably a most important controlling factor in tadpole and frog populations, but they act catastrophically.

In Chapter I, I showed from the work of Douglas, Moore and Volpe that the southern limit of distribution on this species is probably fixed by the temperature, which is lethal to the eggs and embryos if it is over some quite low limit. The effect of temperature on large numbers of organisms is the subject of very large-scale experiments every day, for the canning industry carries out such work in the course of ordinary production. Contrary to what might be expected, cans of food are not subjected to temperatures certain to kill all organisms, for this would damage the food. The processes are devised to kill or make dormant so many organisms that the chance of one surviving to give trouble is so low that complaints do not arise often enough to be important. It is a statistical operation, depending for success on a sufficiently low value for the probability. Bacterial populations vary in their resistance from cell to cell and from species to specics, the variations are inherited and follow statistical laws. The larger the number of cells present, the greater the chance of having a resistant specimen in the can. The canner aims, therefore, at having his material 
as free from bacteria as possible before he sterilizes it. If he does not do this, satisfactory processes may fail-that is, sterilization is population control by inversely density-dependent means.

It seems almost certain that the destruction of eggs and embryos by heat would follow the same laws, so that the more eggs an individual frog laid in the regions where heat death is important, the larger the chances of the survival of some offspring. Now, Boulenger (1897), almost certainly working on British frogs, counted I,ISS to 2,044 eggs in five frogs. Héron-Royer (I885), certainly working on French frogs, counted from 2,856 to 4,005 , almost twice as many. It is not known exactly where Héron-Royer obtained his frogs, but he published much of his work in the proceedings of a scientific society in the provincial town of Angers, about I 50 miles north of the southern limit of distribution, and perhaps within the area where heat death might well be found. As a pure conjecture, I suggest that, in this area, natural selection has favoured the frogs having the larger number of eggs, and that this is a case in which the reproductive rate has become adapted to the death rate, through the operation of an inversely density-dependent factor. This is not at all contrary to Lack's hypothesis, for he merely points out that death rates cannot directly control reproductive rates-there must be some other factor working in such a way as to give a selective advantage to an individual with the higher reproductive rate, and all I have done is to show that such a factor may well exist. It is even possible that there is another factor working in the same direction. In France, but not in England, frogs including this species are used as human food. Man is a predator in France but not in England, at least for this reason. If it is unlikely that the population of ducks is increased or diminished in proportion to the population of frogs or tadpoles, then it is ludicrous to suppose that the population density of Frenchmen is dependent on the population of animals that merely provide a tasty dish from time to time. At the very least, therefore, we cannot look for directly density-dependent relations between frogs and Frenchman. More probably, we should expect that a shortage of frogs would result in redoubled efforts by frustrated Frenchmen, so that we should have another inversely density-dependent factor. The custom of eating frogs may well be very ancient, and it is surely not too far-fetched to consider the effects of an additional and ingenious predator.

To summarize my conclusions on the factors responsible for the 
natural regulation of the numbers of tadpoles in an area, I should say that, within any pond, they are regulated by predation or shortage of food in these parts of the range where heat death is uncommon, but in the extreme south, possibly by heat death as well. Now, the number of metamorphosing frogs in any area depends not only on the numbers of tadpoles that the frog-ponds can support, but also on the number of frog-ponds. This is not nearly as obvious as it sounds, for an area may be well supplied with ponds, none of which is a frogpond. It is only a certain kind of pond that will do for the frogs. It is unlikely, in my opinion, that the tadpoles have any reciprocal effect on the ponds. They are only there for about three months, and the reproductive processes of the algae and other food organisms are mostly so rapid that, even if the tadpoles made serious inroads on them, it is probable that by next spring this effect would not be noticeable. A quantity of water with no life in it, exposed to the air for nine months, will be teeming with life if it is chemically rich enough to support it. I think that the continual passage of ponds through phases in which they are used by frogs followed by periods when no frogs visit them has a very important influence on the numbers of frogs living on the land near the ponds. It is probably much more important than any density-controlled events in the population of tadpoles, and corresponds to the effect on birds of the felling of a wood, or in insects to the disappearance of a food plant. It differs in being far less obvious to our senses, for the ponds do not disappear from sight. They do seem to disappear from the notice of frogs.

Table I, already discussed, shows the irregular nature of the phenomenon, using merely the presence or absence of spawn as the distinguishing feature. If the numbers of frogs using the pond is considered, there are even more striking changes. From about 1927 to I935, Large Totteridge was used by frogs, and the numbers at the peak of popularity were about one thousand. They then began to decline in number in the middle thirties, and dropped to about fifty in 1938 . They then were reduced to zero, and have been absent ever since, although I have not kept observations every year, and it is possible that there have been exceptions. I did not know of Hospital Pond until I948, when the tadpoles had already hatched, and I could not estimate the quantity of spawn. In 1949, the number of clumps was about three thousand, more in one place than I have ever seen. In the next few years, there was a rapid decline, and in 1958 there 
were none. Moreover, Upper Parkfield and Lower Parkfield, a short distance away, have also lost their frogs, possibly because swans were placed on Upper Parkfield, and sometimes move to Lower Parkfield. In 1960 there were no swans and spawn was found in Lower Parkfield.

Passing now to the factors regulating the abundance of the adults, it is easy to see that the upper limit is set by the numbers of metamorphosing tadpoles. Nothing that happens in the frog population can have any influence in raising the numbers above this ceiling, but the numbers may be reduced. I shall later show that food shortage among the adults is probably never a limiting factor. Predation may perhaps be important in some places, and is mostly catastrophic when it occurs, but it is more appropriately discussed later. On the whole, when the tadpole has metamorphosed, the main risks are over.

So far, I have dealt with relative numbers. It is not difficult to carry out a census of breeding frogs in an area, for the spawn is laid in conspicuous parts of the pond. With a little practice, it is easy to estimate the number of clumps. If all the ponds in the area are known, the census is probably at least as accurate as those on other animals. By these methods, I calculated that the area of about a square mile round Large Totteridge in the thirties contained about three or four breeding frogs per acre. In 1949, I estimated that a similar area near Hospital Pond contained rather more, say five or six. I know of no other census for this species, but for comparison, Syrrophus marnockii, a species of toad with the unusual habit of laying its eggs in the soil, was recorded by Jameson (I955) as having populations of this order, but that Pearson (I955) found numbers of the Spadefoot Toad, Scaphiopus holbrookii, of many hundreds and even more than a thousand per acre in some areas.

Whether one can regard the name "Common Frog" as appropriate for this species is perhaps a matter of taste. It is not nearly as common as many people think who gain their impressions from the conspicuous breeding habits of the animals, and assume that the countryside is as densely populated as the small part of it that they happen to see in the spring.

Food for the adults is, I think, never a limiting factor. I have no direct evidence for this statement in this species, but there are two suggestive reports in other species. A colony of $B$. bufo, required for physiological experiments, has been kept in a wire enclosure where the toads sheltered under turf. It was found unnecessary to feed them, 
for they remained in fat condition all the summer on food that entered the cage. The population density was far higher than ever occurs in nature, and the only conclusion is that the animals were in the presence of a great surplus of food. The other example is to be found in the paper on Scaphiopus already cited. The population of these toads was enormously greater than ever occurs in $R$. temporaria. It is, of course, true that these examples involve the assumption that the food and other ecological factors of the different species were the same. This cannot be quite true, but there is in most species a considerable overlap in the kinds of food taken, and I do not believe that in the presence of so much food for toads, frogs would starve.

\section{Mortality}

By making approximate estimations by eye, I concluded that in most years, there were only about I per cent of the original number of tadpoles at metamorphosis. A rough but quite independent estimate, based on the rate of infestation by $P$. integerrimum (Chapter ro, Appendix If), gave a mortality estimate of the same order. When it is remembered that in half the ponds the mortality is roo per cent, we must conclude that the average mortality is well over 99 per cent. For the sake of argument, let us suppose that the mortality is 99 per cent. Then of the I, 500 eggs laid by the frogs, fifteen become little frogs. Frogs become sexually mature at three years old, perhaps sometimes at two (Smith, I95I). This can also be checked by the life history of $P$. integerrimum for the bladder form of the parasite becomes mature at three years old, and is therefore ready to lay eggs just when its host does so for the first time.

If, as I assume for the sake of simplicity, the number of frogs remains stationary, then the total mortality of the frogs that are the progeny of one pair must be no more than thirteen frogs in three years. It is probable that frogs breed in more than one season (in R. clamitans, there is definite evidence (Martof, 1953) that some may breed for three seasons-Juszczyk (I95I) found the same in $R$. esculenta) so that this mortality is probably over-stated at about 30 per cent per annum. Lack estimates that the mortality of most small birds is about 30 to 60 per cent per annum, so that the frog lives by comparison a fairly safe life. Robins (Lack, I954) have an expectation of life of just over a year, so that it would be most exceptional for any robin hatched at the same time as a tadpole to be alive when the frog that the tadpole 
became enters the water to breed. If the same sort of comparisons are made with mice, and we suppose that we have a pair of mice and a pair of frogs, and no deaths occur, we arrive, on a conservative figure, at a population of mice of about half a million, to compare with $\mathrm{I}, 500$ frogs.

It is difficult to say how the idea that frogs have an exceptionally high death rate came into the literature. It has been there for a long time, for Roesel (I758) and Smith (I95I) both have it. It probably happened because when a frog does die, it often does so in a conspicuous manner, by being eaten at the time of the year when large numbers of them congregate for breeding in the ponds. It does seem, however, that the many writers who have perpetuated this myth have been uncritical, for a slowly maturing animal that only lays I,500 eggs per pair per year cannot have a high death rate. It is, however, only fair to point out that the high death rate in birds, which I have used for comparison, was greeted with incredulity by Lack's first audiences on this subject, and that the high death rate in tadpoles, which accounts for so many deaths in $R$. temporaria, was not published until 1952 .

In the hope of getting rid of the idea, the following short summary might serve as a model for future authors: "The reproductive rate and the death rate of frogs is lower than that of many other small animals, in spite of the fact that birds and mammals protect their young. Most of the deaths take place in the tadpole stage. Frogs live a safer life than most other small land vertebrates."

The safety of the life of $R$. temporaria is, however, greatly surpassed by that of another Anuran which lives in small ponds not unlike those that are used by the frog. Bombina variegata lays only about 80 eggs in a season. It does so, however, in the summer, laying at intervals of some weeks, and choosing different portions of weed to which the female attaches the eggs a few at a time. A catastrophe to one lot of eggs does not imply that this female will leave no progeny in that season. Moreover, the adult has warning coloration which it displays when attacked. Even so, this is a remarkably low reproductive rate for an animal that does not look after its young. Anuran life must be a placid affair compared with that of those unfortunate birds and mammals.

\section{Predators of Adult Frogs}

I remarked earlier in this book that any natural event in the life of an animal that is certainly seen by even one observer is probably part 
of the pattern of life of the animal. Although, therefore, most of the information about predators of frogs is anecdotal, it is likely that the list of predators given by Smith (I9ৎI)-hawks, owls, crows, gulls, ducks, terns, herons, hedgehogs, stoats, weasels, badgers, otters, rats, and snakes-is a fair indication that many animals will eat the frog if they can find it. It is, however, very difficult to come to any quantitative conclusions on the available information, for this is scattered through the litcrature on other animals, often in the form of casual comments not indexed by abstractors. If one considers the size of most of the animals in the above list, and the density of the frog population, say five frogs to the acre, it seems unlikely that any except the last can be dependent on the frog as a source of food. Probably they use frogs at certain times of the year, and feast for a few days, but, at other times, chance on frogs by luck, and then add an inconsiderable item to their diet. It is therefore difficult to believe in any reciprocal predator-prey relation. More probably, these animals act as catastrophic agents, and they may be important in this way. Onc in particular deserves special attention.

I have known some of the ponds in my area for at least forty years. I have never considered that the mallard duck (Anas platyrhynchos) was typically a bird of the small ponds used by frogs. It occurred on some of the larger ponds, and on my nightly rounds in the thirties, I disturbed a pair, not always on the same pond, but never on more than one, so that I concluded that it was the same pair, and the only one in about a square mile. In 1958, the frog population was less than I have ever known it, and I found the mallard on many remarkably small ponds. Two of these had two pairs, and the vegetation was obviously chewed to an extent suggesting pressure on the food supply. It was difficult to believe that either frogs or tadpoles could survive in these ponds. If the birds visit other ponds in the neighbourhood in turn, as I believe they do, then the shortage of frogs would be easily explained by the increase in the population of ducks, but whether this is really the explanation is uncertain.

Another predator that may sometimes be important is the moorhen, Gallinula chloropus. As I pointed out in Chapter I, this bird occasionally eats spawn, but is erratic in this behaviour. Bentlcy Heath Church Pond almost always has a pair of these birds, and generally has spawn as well. I never know whether the birds are going to attack the spawn or leave it entirely alone. When they do eat it, they leave little or 
none to hatch into tadpoles, so that this is another case of catastrophic control of numbers.

The snake, Natrix natrix, is, however, perhaps in a different category. It is not a very large animal, one frog forming a meal that may last for days, it hibernates in the winter, and it lives in similar places to the frog. It is possible to conceive that the numbers of snakes varies with the numbers of frogs in one of the ways suggested by those who have studied these reciprocal relations. I have no close knowledge of the density of the population of frogs in Ireland, where there are no snakes, but in the south-west I saw more than I have seen anywhere else except in the Alps, and a correspondent, Mr. C. Faris, reported so many that I scarcely recognized his picture of numbers in comparison with mine. It is possible that a controlling factor is absent from Ireland, so that the normal level of population is higher than in England. But perhaps climate is at the bottom of the matter.

\section{Disease}

As in most other wild animals, records of disease in frogs are almost absent. I once found a spent female frog dead beside a spawn pond. Her lungs were so full of nematodes that I concluded that they could not be functional. She probably died when, her water-life over, she attempted to resume her role as a land animal, dependent on aerial respiration.

\section{Man as a Predator}

In spite of the fact that, when we deal with our own species, we should be well informed, there is much doubt about the part man plays as a predator. Fischer-Sigwart (1897) working near Zürich in Switzerland has a detailed account of the effect of catching frogs for food. He describes how the frog-catchers took 1,500 pairs a night from the ponds he was studying. Taking advantage of the high degree of local autonomy in Switzerland, Fischer-Sigwart persuaded the Commune to ban the taking of frogs. The frog-catchers evaded the law by coming stealthily by night, but eventually, Fischer-Sigwart found ponds out of their reach, and was able to continue his studies. This is a very detailed account, and with this large drain on the local supplies of frogs, there must have been a danger of extinction. But Fischer-Sigwart says that the decline began before the frog-catchers arrived, and the numbers taken were so large that, even then, there 
must have been far more frogs than I have ever known in a district. I cannot help wondering whether Fischer-Sigwart was not witnessing one of the violent fluctuations so characteristic of this species, of which man is only one cause.

Smith (1953) considers that the demands of laboratories in the British Isles amounts to at least I 50,000 frogs every year. This scems a very large number, until one calculates some proportions. Taking five frogs per acre as a fair average for the whole country, i 50,000 frogs is approximately the entire population of about fifty square miles of country. This could be devastating if concentrated in one area, but this is unlikely. It only represents 0.04 per cent of the total area of the British Isles, and this is really the measure of the effect of taking I 50,000 per annum. I think it is almost certain that in countrics that have the custom of eating frogs, the numbers taken must be much larger. A dish of grenouilles aux fines herbes contains many frogs, and there are more gourmets than laboratory workers.

Fatio (1872) made arrangements with the peasants who brought frogs of this species to the Geneva market, so that he could examine variations in the colour and markings. In December, January and February, I860-I86I, he examined in this way more than I2,000 specimens. There is no indication that he saw all that were brought to market, and Geneva is only one town in Switzerland, a country with an area only about half that of Scotland. It is probable that the number of frogs eaten in Switzerland must have been at least as large as the present demands of laboratories in the British Isles, and probably far more. This trade has, we must assume, been going on for centuries, but thirty years later, Fischer-Sigwart's frog-catchers were still at work, and took very large numbers.

Nothing I have said in the last paragraph should be taken as supporting the practice of using wild animals that breed slowly and are not very common for scientific purposes on this scale. Every effort should be made to use animals that can be bred in captivity, so that a sudden and new load is not placed on a natural population. Smith suggested that something can be done to counteract the drain on the frogs by dispersing clumps of spawn into different parts of the pond. I am, however, doubtful if this is the right way, for the habit of massspawning is adaptive. My own suggestion is addressed to school teachers, who often ask their pupils to collect spawn for life-history instruction. Usually a child brings a whole clump, far too many for 
the purpose, but if this does happen, and the tadpoles are given plenty of room and are well cared for, the final mortality may be well much less than the 99 per cent or more that occurs in the ponds. The return of, say, fifty full-grown tadpoles to the pond might serve as a lesson in the conservation of the fauna, and result in more little frogs than if the clump had never been taken at all.

I have often watched the behaviour of children at frog-ponds. I do not think they are serious predators. Tadpoles are not "game." Fish, however small, are "game." I think a child with tadpoles in a jar is either very young, or has not been lucky enough to get fish. Children should be taught not to take home whole clumps of spawn. Apart from predation, man has many other influences. In the lowlands, almost all ponds are artificial, having at some time been dug by man for watering cattle or as excavations for gravel. Before the rise of agriculture, there may have been marshes but no ponds as we know them. Moreover, the country was largely covered by forests. This species is not a wood frog, and it is quite possible that the present population of frogs owes its existence, except in the mountains and in certain areas with marshes, to the activities of man.

\section{Conclusion}

In this chapter, I have been following a rather tangled thread, in which abundance, mortality, and distribution have all been considered. They are related subjects, hard to separate into neat compartments, but it may now be possible, in the light of what I have written, to explain more fully the reservation I made about the theories on the regulation of animal numbers that have occupied the attention of ecologists for at least twenty-five years, and which still give rise to discussion and to controversy.

In his paper on this subject, Nicholson (1933) began with an analogy which was a description of the way in which a balloon maintains its height. Even if it is displaced by some force, it regains its original position and the larger the displacement the greater is the restoring force. He stated definitely that "only" factors that operate in a similar way, and act more strongly the greater the departure from normal, were capable of acting as controls of animal populations in which "conditions" remained the same. The exclusive form of this statement was not based on ecological facts, such as a failure to find any example of a fluctuation that was not restored by this kind of action, but seems 
rather to rest on a belief, obtained from analogies, that systems that tend to some mean value always arise in this way. Nicholson's views are not universally accepted, and Solomon (I949) has brought together in a wide review many of the other theories on this subject. It secms curious that the very large number of cases in which complex systems are maintained at levels fluctuating within limits, but which are demonstratively not due to this kind of control were not used as analogies. If examples had been taken from complicated systems such as are found in molecular physics, life assurance or the innumerable properties examined in industrial control laboratories, the belief that there must always be a restoring force related to the displacement could surely not have become so widespread.

In a volume of gas at constant temperature, the velocity of the molecules is maintained at a constant average merely because of a statistical set of probabilities. There is nothing that tends to accelerate a slow molecule merely because it is slow-all that happens is that in this complicated situation, there is a slightly greater chance that at the next collision it will be accelerated rather than slowed. Except in this sense, which is not that usually used in these discussions, there is no "velocity-dependent" control and, in fact, a slow molecule is sometimes slowed still further.

If we now look to our own species for an ecological example of control by purely statistical means, we may consider the population density of Homo sapiens in one of its ecological niches, the 4 o'clock week-day train from Manchester to London. The numbers of the animal fluctuate between fairly small limits-the train is never empty, but I have never seen anyone left behind. Not the slightest attempt is made by British Railways to control the numbers-anyone can buy a ticket and board the train. The only reason why all Manchester does not try to do so, or all try to stay at home, is that human life is so complicated that the chance of either of these events is negligible. If the train is crowded on Tuesday, it does not in the lcast follow that it will be less crowded on Wednesday, although this is probable. On Sundays, it is very different. The railways would then be used too little, so British Railways issue cheap tickets, and so exert density control.

The death rate is not in the least influenced by the experience of life offices, but, after an exceptional period of very many or very few deaths, the mean value is soon regained. In some countries, there may 
be density-dependent control. In industry some machines have controls upon them that vary the operation of the machine according to the properties of the product at the moment, but in many others, it is the improbability that, say, fifty independent sources of variation should all act in the same direction for long that keeps the product approximately uniform.

To quote Solomon: "There is evidence that animal populations fluctuate less violently in very complex ecosystems, for example in tropical forests, than in woods poorer in plant and animal species, and that the most violent fluctuations tend to occur among the animals in plantations of one species, or in barren places like the far north."

Davidson and Andrewartha (1948) accounted for 78 per cent of the variance in the numbers of the insect they studied by considering only four weather factors. Error variances of 22 per cent commonly occur in biological assays, conducted with the aid of thermostats and other equipment, so that these authors are certainly right in considering that they had no need to look to "density-dependent" factors to explain the fluctuations of the insect. Perhaps most of the theories have something right about them, for in tadpoles there are times when density-dependent factors seem to come into action, but I doubt very much if they are always acting.

"And I am right,

And you are right,

And all is right as right can be." (Gilbert, I885)

\section{REFERENCES}

Balcells, E. (1956) P. Inst. Biol. Apl., 24, 8I-I2I.

Biggs, R. and Macfarlane, R. G. (I95I) Human Blood Coagulation and its Disorders (Blackwell, Oxford).

Blair, W. N. (I927) Proc. zool. Soc. Lond., 999-1002.

Boulenger, G. A. (1897-8) The Tailless Batracians of Europe (Roy. Society, London).

Carpenter, C. C. (1953) Herpetologica, 9, 77-8.

Davidson, J. and Andrewartha, H. G. (1948) J. Anim. Ecol., 17, No. 2, 200-22.

Diver, C. (1933) Geog. J., 8I, No. 5. 404-27.

Fatio V. (1872) Faune des Vertébrés de la Suisse (George, Geneva).

FISCHER-SigWART, H. (1897) Vjschr. naturf. Ges. Zïrich, 42, 238-316. 
Gadow, H. (1909) Cambridge Natural History, 8, 72 and I77 (Macmillan, London).

Gilbert, W. S. (I885) The Mikado (Chatto \& Windus, London).

Héron-Royer (1885) Bull. Soc. Etud. Sci. Angers, 92-I 34.

Jameson, D. L. (r9ss) Amer. Midl. Nat., 54, 342-8 I

Juszczyk, W. (I95I) Bull. int. Acad. Cracovie (Acad. pol. Sci.), 369.

LACK, D. (1954) The Natural Regulation of Animal Numbers (Clarendon Press, Oxford).

Martof, B. (1953) Ecology, 34, No. I, I65-74, 529-43.

Nicholson, A. J. (I933) J. Anim. Ecol., 2, 132-78.

Noble, G. K. and Noble, R. C. (1923) Zoologica, N.Y., 2, 417-55.

Pearson, P. G. (I95s) Ecol. Monogr., 25, No. 3, 233-67.

Roesel, A. J. von R. (1758) Historia Naturalis Ramarum Nostratium (Flcischmann, Nürenberg).

Savage, R. M. (1935) Proc. zool. Soc. Lond., 49-98.

Savage, R. M. (1939) Proc. zool. Soc. Lond., A, 109, No. I, I-I9.

SмITH, M. A. (1938) In letter from H. W. Parker.

Smith, M. A. (I9SI) The British Amphibians and Reptiles (Collins, London).

Sмith, M. A. (1953) Ctry Life, Lond., Sept., 770-I.

Solomon, M. E. (1949) J. Anim. Ecol., 18, No. I, I-35.

TAYLOR, R. H. R. (I948) Brit. J. Herpet, I, I-38.

Wright, A. and Wright, A. A. (1949) Handbook of the Frogs and Toads of the United States and Canada (Comstock Publ. Co., Ithaca, New York). 


\section{Chapter 7 \\ FOOD, HIBERNATION AND MIGRATION}

\section{Food}

THE most extensive work on the food of frogs has been carried out by Cott. Much of his work has been on other species, and is for the most part published in connexion with his distinctive studies on selective predation as a factor of adaptation, and has not been published as a

TABLE 2

FOOD TAKEN BY I7 FROGS AT LAND'S END, CORNWALL

\begin{tabular}{|c|c|c|c|c|}
\hline \multicolumn{3}{|c|}{ Food Taken } & \multirow{2}{*}{$\frac{\text { Numbers }}{\text { II }}$} & \multirow{2}{*}{$\frac{\text { Percentage }}{4 \cdot 8}$} \\
\hline Apterygota & . & . & & \\
\hline Hemiptera & - & - & Is & $6 \cdot 6$ \\
\hline Coleoptera & . & - & 28 & $12 \cdot 3$ \\
\hline Diptera & . & . & $2 I$ & $9 \cdot 2$ \\
\hline \multicolumn{5}{|c|}{ Lepidoptera: } \\
\hline Adults & - & - & 4 & $\mathrm{I} \cdot 8$ \\
\hline Larvae & . $\quad$. & . & 26 & II 4 \\
\hline Hymenopte & era (Ants) & . $\quad$. & I & 0.4 \\
\hline \multicolumn{3}{|c|}{ Hymenoptera (Other than ants) } & IO & $4 \cdot 4$ \\
\hline Oligochaeta & a . & . $\quad$. & 2 & 0.9 \\
\hline Isopoda & . & . & 27 & II $\cdot 8$ \\
\hline Phalangidea & . & . & 9 & $3 \cdot 9$ \\
\hline Arachnida & - & . & 5 & $2 \cdot 2$ \\
\hline Acarina & . & . & 3 & $I \cdot 3$ \\
\hline Chilopoda & . & . & 8 & $3 \cdot 5$ \\
\hline Mollusca & . & . & 58 & $25 \cdot 4$ \\
\hline Totals & - & - & 228 & $99 \cdot 9$ \\
\hline
\end{tabular}

contribution to the ecology of this animal in particular. Smith (I95I) has, however, tabulated many of Dr. Cott's results, and the following account is taken from this source.

Tables 2, 3 and 4 show the detailed analyses. It can be seen that the main food of frogs in these areas, some from near Land's End in Cornwall and some from other parts of the country (including frogs killed on Totteridge Lane and collected during the migration studies described in the next section of this chapter), is molluscs, mostly slugs. Toads collected in the same areas had, on the contrary, eaten large numbers of ants, which frogs hardly eat at all. Now, it seems that 
there are at least three reasons for these differences in the kind of food eaten by these animals. The first is that frogs and toads do not live in quite the same places, even if they are collected in the same area. Frogs prefer the damper parts, but toads are more usually found in drier places. It follows that the kinds of food available to the animals

TABLB 3

THE CONTRAST BETWEEN THE FOOD OF FROGS AND TOADS

\begin{tabular}{|c|c|c|c|c|c|c|}
\hline \multirow[b]{3}{*}{$\begin{array}{l}\text { Toad } \\
\text { Frog }\end{array}$} & \multicolumn{3}{|c|}{ Predators } & \multicolumn{3}{|c|}{ Prey } \\
\hline & $\begin{array}{l}\text { No. of } \\
\text { Stomachs } \\
\text { Examined }\end{array}$ & $\begin{array}{l}\text { No. } \\
\text { Containing } \\
\text { Ants }\end{array}$ & Percentage & $\begin{array}{l}\text { Total No. } \\
\text { of Food } \\
\text { Animals }\end{array}$ & $\begin{array}{l}\text { No. of } \\
\text { Ants }\end{array}$ & Percentage \\
\hline & $\begin{array}{l}352 \\
282\end{array}$ & $\begin{array}{r}145 \\
8\end{array}$ & $\begin{array}{r}4 I \cdot 2 \\
2 \cdot 8\end{array}$ & $\begin{array}{l}8,694 \\
I, 120\end{array}$ & $\begin{array}{r}4,239 \\
9\end{array}$ & $\begin{array}{r}48.7 \\
0.8\end{array}$ \\
\hline & $\begin{array}{l}\text { No. of } \\
\text { Stomachs } \\
\text { Examined }\end{array}$ & $\begin{array}{l}\text { No. } \\
\text { Containing } \\
\text { Mollusca }\end{array}$ & Percentage & $\begin{array}{l}\text { Total No. } \\
\text { of Food } \\
\text { Animals }\end{array}$ & $\begin{array}{l}\text { No. of } \\
\text { Molluscs }\end{array}$ & Percentage \\
\hline $\begin{array}{l}\text { Toad } \\
\text { Frog }\end{array}$ & $\begin{array}{l}352 \\
282\end{array}$ & $\begin{array}{l}26 \\
84\end{array}$ & $\begin{array}{r}7 \cdot 4 \\
29 \cdot 8\end{array}$ & $\begin{array}{l}8,694 \\
I, 120\end{array}$ & $\begin{array}{r}32 \\
226\end{array}$ & $\begin{array}{r}0.4 \\
20 \cdot 2\end{array}$ \\
\hline
\end{tabular}

TABLB 4

FOOD TAKEN IN THE WINTER

\begin{tabular}{|c|c|c|}
\hline Month & No. Examined & No. with Food \\
\hline December & 40 & 7 \\
\hline January . & o & 0 \\
\hline February & IO & 3 \\
\hline March. & 73 & 5 \\
\hline
\end{tabular}

are not the same- they eat what happens to be there. The sccond reason for the differences is that the Anura in general are not indiscriminate feeders. For examples drawn from my own cxperience of them in captivity, I found that Bombina variegata are adcpt at taking fies from the surface of the water in which these aquatic toads usually float, and also eat slugs skilfully, even though these are large prey for these small toads. They reject mealworms. No tree frogs (Hyla) will, to my knowledge, take earthworms readily, but become alert in the presence of flying insects. These are all instances in which the animals seem to be most ready to feed on prey that they are most likely to find in their natural habitats. Cott (I936) showed that there was a third reason for 
food preferences. The toad, B. bufo, learned to avoid bees by trial and error, and Cott considers that this form of natural selection has contributed to the evolution of such modifications as warning coloration in insects.

The feeding habits of frogs, as distinct from the nature of the food found in the stomach, have been very little studied. It is sometimes said that the animals "hunt" or "forage." In fact, however, they seem during the day to remain in their hiding place, fully alert, and take any suitable prey that comes within the short range of their not very good eyes. A worm ten or fifteen inches away may pass unnoticed, but if it is moved nearer to, say, three inches it may be eaten at once. Now this cannot be called hunting-it is far too passive. On the other hand, it is more active than the fishing of a sessile animal such as the barnacle, which puts out its net and takes in anything that passes. Perhaps the nearest human analogy is that of the wild-fowler who places himself where he thinks the birds will come, does nothing to make them fly over, and shoots when they come within range. In both cases, success depends on the right selection of the place to hide in, at least as much as in the accuracy of the shooting. At night, however, the frogs wander. It may be true that these wanderings are for feeding, but, as usual in amphibian movements, they stay still for such long periods that it is surely questionable whether they meet with more food in a given time than if they kept still. Perhaps they are merely moving out from a place depleted of food by their day-time feeding, or moving into an area populated by nocturnal prey but not abundantly supplied with food in the day-time. On these questions there is room for some good, old-fashioned natural history observations, with pencil, notebook, and watch as the instruments. With a frog in its natural hidingplace as the object to be studied, and a team of patient observers who would watch and time events round the clock, we might achieve "A day in the life of a frog" of considerable interest.

We seem to know rather little about underwater feeding in this species. Boulenger (1897) did not consider that the frog feeds at all when under water, but here are two mutually supporting lines of evidence to the contrary. Smith (1949) records that in frogs caught in January and February, the larvae of aquatic insects were found. Moreover, parasitologists say that the intermediate host of the intestinal parasite, Acanthocephalus ranae, is the water louse, Asellus aquaticus. When parasitology and ordinary observation agree like this, it becomes 
difficult to avoid the conclusion that during hibernation under water, the frog eats aquatic animals, It is, of course, possible that the food is eaten when it is stranded above water, but there is not the smallest cvidence for this, and it is more logical to accept the surprising information as it stands.

\section{Hibernation}

This is a subject on which, for a change, there is a considerable amount of information, and the two dissenters are undoubtedly wrong.

Fatio (I872), Mailles (I88I), Wolterstorff (1904), Boulenger (I9I2), Barthélémy (1926), Hecht (1930) have accounts that agree with one another and with my own observations. Héron-Roycr (1885), usually an acute observer, did not believe that the frog hibernates under water, and this scepticism was shared by the natural history correspondent of the Observer in 1934, Mr. Eric Parker. The result of this was a series of letters from people who had themselves seen frogs hibernating under water, with such details that they form a considerable contribution to scientific literature from an unusual source. In the following description, I draw from all the authors cited above, and from my own observations.

It is undoubtedly true that frogs hibernate both on land and under the water. Hecht considered that most of them hibernate under water, particularly if there is a current, but I feel that there is some doubt about the evidence. It is easier to find them under water, because they can sometimes be seen, or dredged up from the bottom. Moreover, the area of water in any normal area of country is very small compared with that of the land. Even if an equal number of frogs hibernated in both situations, there would be a far higher concentration of the animals in the water. It is indeed often hardly practicable to scarch some possible place for land-hibernation. In one winter, I dredged two streams, and found one frog in each. As I passed along the beds of the streams, I saw innumerable crevices in the banks in which frogs might have been lurking, but to search even one or two of them would have needed pick, shovel and axe, for the crevices were among the roots of the hedge. The total number of such inaccessible habitats in a square mile of country must be prodigious, and it seems that only luck can lead to one that really does contain frogs. It is noteworthy that almost all the records in the literature are of accidental finds-someone 
moves a rubbish-heap, or takes up a drain, and finds frogs therein. The frog-dealers are reputed to obtain their supplies from rivers and streams, but they do not write papers about their methods.

It is obvious that if frogs are to escape destruction by frost, those that hibernate on land must be sheltered, and almost certainly in the dark, a fact of importance for the next chapter. Those in the water are often in the dark, too, for they are buried in mud, or in drains. But sometimes they are in the light, and can be seen from the bank. One of the Observer's correspondents described the frogs as spreading themselves out over the bottom of the pond when the sun was shining. In one of the ponds in which I have found frogs, they were sheltering under stones in the dark, but in the other they were in the light. Perhaps the most interesting letter was from a Polish observer, Miss I. Rovzewska, who found frogs separately frozen into the ice of a small pond. They revived when thawed in warm water. In Poland, ponds normally freeze to the bottom, but it is evident that, nevertheless, the habit of underwater hibernation is found in that climate as well as in the mild British Isles.

Hibernating frogs are not torpid as a rule. One I found under water with its head wedged in a crevice of the bank was in the same place a week later. I have also accidentally killed a frog in January in my garden which was sheltering under a board with frost on its upper surface. The frog had recently eaten a meal, and I suspect that it had been foraging on the previous night, which had not been very cold for the time of the year. The frogs I dredged up from the streams swam rapidly away when I released them.

Frogs are, of course, well adapted for underwater hibernation, for they have good cutaneous circulation and at low temperatures have no need of lungs.

The duration of hibernation must vary very much in different parts of the range. In the high Alps, snow only goes from its habitats in early June and may descend again in September, so that the frogs hibernate for nine months. In the south-west of England and Ireland, frogs may spawn in December. If these frogs go into hibernation at about the same time as other frogs, say in late October or November, then it appears that they cannot hibernate for more than about one or two months. In these areas, hibernation may well start later than in the rest of the country, so that the period may be even shorter.

It is generally considered that hibernation is necessary for normal 
reproduction. If this is so in nature, then this might be another factor limiting the distribution of this animal to countrics cold enough for hibernation to occur. But our warm areas owe their mild climates so much to occanic influcnces that places much further south on the Continent have colder winter climates than Cornwall or Kerry, and, on the whole, it scems more likely that other factors are at work, as suggested in Chapter I.

As so often happens, this question is made more difficult because the physiological experiments are carricd out on frogs in captivity, commonly under very artificial conditions. However good the observations and experiments may be, they could be quite irrelevant to events in the ficld. A frog in Cornwall which never hibernated for long, if at all, might in nature become sexually mature all the samewho knows?

In spite of the generally satisfactory state of the information about hibernation, it is, of course, incomplete and qualitative. Dolk and Postma (1927) showed that frogs use fat but not carbohydrate during hibernation, but apart from this there do not seem to be any ecological quantitative measurements, such as temperatures of the hibernacula, losses or gains of water, speed of digestion and frequency of feeding.

\section{Migration}

In the late winter and early spring, frogs move from their winter quarters to the breeding ponds. We have now to consider how they behave when on migration, what prompts them to begin the journey, and how they are guided to their destination.

There is a fairly considerable literature on the migration of other species, but, except for some observations by Neal (1956) dealing with the arrival in the pond, there seems to be no detailed work on the actual migration of this frog, except in my 1935 paper. It seems therefore desirable to begin with an account of what happens in the ficld, before going on to analyse the reasons for the things that have been seen.

It is sufficient for this purpose to take that part of the migration that took place near the main pond, Large Totteridge, used for these observations. Reference should be made to the map, Fig. 25. The pond was situated nearly at the highest point of a ridge rising from a valley at about 200 feet to the summit at about 4io fect, only about thirty yards from the pond. Within the area chosen for this shortened 
account there are ten ponds, and arrangements had been made with the landowners for work to go on all round the pond at any hour of the day or night. Observations were made in four seasons, I93 I-I934, but mainly in the last two. A fairly busy road passes alongside the pond, and large numbers of frogs were killed by the traffic. It is reasonable to suppose that the same fraction of the total numbers of frogs crossing the road was killed every night. This provided a method of estimating quantitatively the amount of migration, for I passed along the road almost every day early in the morning, and had only to collect the bodies to get the information I needed.

In the winter of I933 I came to the conclusion that, if the smell hypothesis was correct, I should find frogs working their way up streams that flowed out of ponds, because these streams would contain odorous water. Frogs, hopping at random in the fields, on coming to such a stream have only to follow it upwards to reach the pond. They ought not to be found to the same extent in ditches that do not have their origin in ponds. The winter was wet, and, when I started night observations, the ponds were full. On gth March, there were many frogs already in Large Totteridge, with much croaking. On the Ioth, I searched the rising ground above the pond, which includes several ditches running into it, but found no frogs. On the road, however, I found three recently killed ones, all pointing towards the pond. In the drainage ditch that runs under the road, and contains pond water, there was a pair facing the pond about a yard from it. Farther west on the road, there was a dead female facing the pond. In Middle Totteridge, a pond not usually used by frogs, there was a female on the west side, and at the roadside six yards farther west, there was a male facing the pond. No frogs were seen in West Totteridge.

On the I 5 th, there was much croaking in Large Totteridge, but I could see no frogs going to it. There was a pair at the roadside edge of Middle Totteridge, and I found a female at the south-west corner, a male in the outflow ditch to the west, and, farther along the same ditch, a pair scrambling up the bank. On the I6th it was raining. Frogs were in East Totteridge, and I found a female crossing the road to it. I found no frogs in the ditch leading out of this pond to the east. There were several pairs and some single animals in the ditches alongside the footpath opposite Large Totteridge, and there were several on the road, all apparently working their way to this pond, and some more in the ditch flowing from Middle Totteridge. There was no croaking 


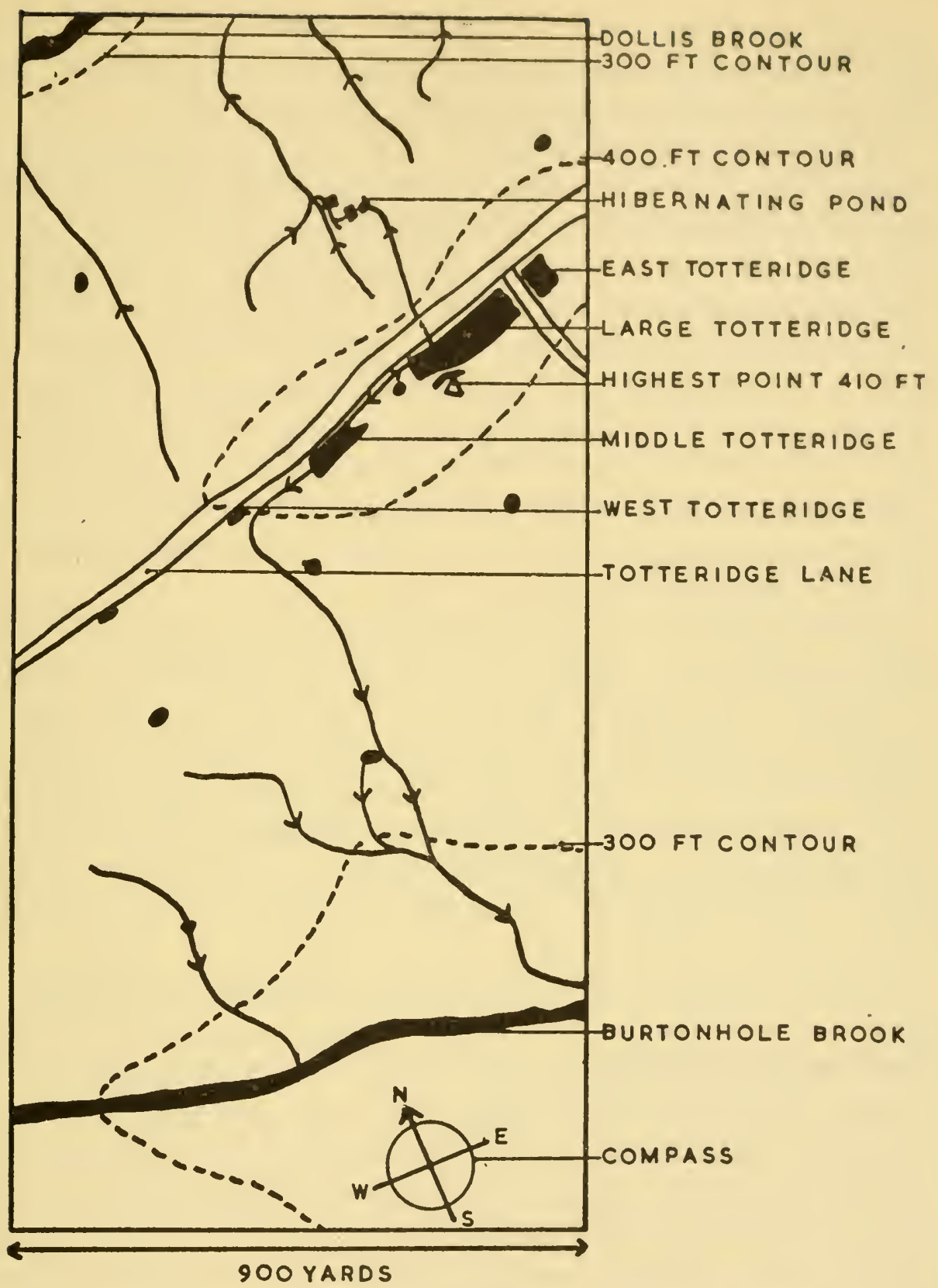

FIG. 25. Map of the Area Used for the Migration Studies

The arrows show the direction of the flow of water in the ditches. Minor ponds not referred to in the text are shown as black patches. Note that the map is not drawn due north and south. 
in this pond. Frogs had arrived in West Totteridge, and there were others at various points near by. Observations were continued on some subsequent nights with very much the same results.

The year I933 was an early year, and the frogs generally spawned on the night they entered the ponds; I934 was a considerable contrast. The winter had been dry and cold, and many of the ponds were not full at the beginning of the season. Spawning was late. In this year, I made observations almost every night for a month, so that the record is nearly complete. I had also been lucky enough to find, in January, a pond about three hundred yards downhill from Large Totteridge in which a number of frogs were hibernating. I felt that they would not spawn in that pond, but would go to Large Totteridge when the time came, so I tagged two of them with paper labels on March $3 \mathrm{rd}$. On the afternoon of March Ioth, I saw no frogs in this pond except one female and one juvenile.

Migration followed the same general pattern as in 1933, but with important differences. Almost the whole of the migration took place before any croaking was heard, and although the frogs steadily assembled in the ponds, and even gathered at the spawn sites, they merely waited there, silent and inactive, night after night, as if they were expecting some signal to begin their breeding activities. Moreover, although many of the ditches were dry, and had been so for about a year, the frogs, in general, followed the same routes as when they were full of water in I933.

The most important observations were, however, those obtained from the marked frogs. The frog marked in Hibernating Pond on March 3rd was found sitting on the edge of Large Totteridge on the evening of March 24th, facing the pond in such a position that with one jump he could have leapt into the pond. I saw the label in the light of my lamp, and managed to secure him and read the number on the label. No spawn had been laid in Hibernating Pond, as I expected would happen, and it is practically certain that all the frogs there migrated to Large Totteridge, although in this year no water from this pond flowed down the ditch as it did in 1933. A frog tagged in Middle Totteridge on March I2th was recovered in Large Totteridge, I80 yards west, on April 4th. The remarkable feature of the migration of this frog was that spawning did eventually take place in Middle Totteridge, but was very late. The first clumps were in fact seen this same evening, so it is probable that $D_{5}$, the frog that made the journey, 
left Middle Totteridge before spawning started there. Another male, EI2, was first tagged in Middle Totteridge on March 23rd, but this frog did not leave the pond, for he was found again there in full breeding activity on April 4th. It is interesting that, at this date, breeding activity in Large Totteridge was almost over, and on the next evening, April 5th, Large Totteridge was silcnt, although there was one malc left, and a female was seen migrating to it. Only i so yards away, the season was just starting in Middle Totteridge, twelve days after Large Totteridge, in spite of the fact that the frogs in each pond were evidently drawn from the same general population.

In Table 5, I show the summarized observations and also the weather of the periods. In the paper, I proceeded to analyse the results with caution, for I did not believe that although there was already statistically significant evidence for migration up-wind, the true position would show itself to be so simple. Large Totteridge, as I have said, is situated on the north slope of a ridge, and all migration apparently took place uphill or on the level. At the time I wrote the paper, there was little evidence about the direction of air currents close to the ground. I considered that these might be the most important, because in Large Totteridge, and possibly many other ponds, air currents under ccrtain meteorological conditions flow as water does, and drain down ditches, whether these contain water or not. There is now more evidence on such matters, although much still remains obscure, and I can now proceed with a more balanced analysis.

The comparison between March 1932 and March 1934 is instructive, because in those two years the spawn date was almost the same ( 82 in 1932 and 83 in 1934). In 1932, except for four frogs on the 7 th, and two on the 19th, there was no migration until the night before that on which spawning started, the 22nd March, when there was a great wave, and another even larger occurred on the 23rd. In 1934, however, migration started on the $\mathrm{I} 2 \mathrm{th}$, and was much more continuous. There were three large waves of migration-on the nights of the I4th, the I 6 th, and the 24 th, this being the spawning date, Most of the frogs reached the pond long before they spawned.

Minimum temperatures occur in the small hours of the morning, but frogs are on the move as soon as darkness falls, so that the temperature that directly matters to them is somewhere between the maximum, occurring in the early afternoon, and the minimum carly next morning. This being so, it is not easy, on the temperature data, to see why the 
IO4 ECOLOGY AND LIFE HISTORY OF THE COMMON FROG

TABLE 5

MIGRATION TO LARGE TOTTERIDGE POND FROM THE NORTH

\begin{tabular}{|c|c|c|c|c|c|c|c|}
\hline \multirow[b]{2}{*}{ Date } & \multicolumn{2}{|c|}{ Frogs Killed } & \multirow{2}{*}{$\begin{array}{l}\text { Rain } \\
\mathrm{mm}\end{array}$} & \multicolumn{2}{|c|}{$\begin{array}{l}\text { Temperature } \\
\text { (degrees C) }\end{array}$} & \multirow[b]{2}{*}{ Wind } & \multirow{2}{*}{ Notes } \\
\hline & ठే & 우 & & Max. & Min. & & \\
\hline I9.3.3 I & \multicolumn{2}{|c|}{6} & $\mathrm{~T}$ & $16 \cdot 5$ & $-6 \cdot 5$ & ESE. & $\begin{array}{l}\text { Weather up to I } 8 \text { th } \\
\text { cold, then warm, } \\
\text { wind turned SSE. }\end{array}$ \\
\hline 5.1 .32 & \multicolumn{2}{|c|}{ I } & $3 \cdot 0$ & 10.5 & $7 \cdot 7$ & SW. & \\
\hline IO.I.32 & \multicolumn{2}{|c|}{ I } & $9 \cdot 0$ & $7 \cdot 3$ & $4 \cdot 4$ & & \\
\hline 14.1 .32 & 0 & $\mathbf{I}$ & $3 \cdot 0$ & $8 \cdot 8$ & $5 \cdot 6$ & SW. & \\
\hline I7.I.32 & I & 0 & $\mathrm{~T}$ & 10.5 & $6 \cdot 6$ & SSW. & \\
\hline $7 \cdot 3 \cdot 32$ & 3 & $\mathbf{I}$ & $3 \cdot 0$ & $10 \cdot 0$ & $2 \cdot 6$ & W. & \\
\hline 8.3 .32 & 0 & 0 & $2 \cdot 0$ & $5 \cdot 6$ & $-x \cdot 7$ & W. & \\
\hline $9 \cdot 3 \cdot 32$ & 0 & 0 & $0 \cdot I$ & $6 \cdot 6$ & $-4 \cdot 4$ & NNE. & \\
\hline 12.3 .32 & 0 & 0 & $\mathrm{~T}$ & $2 \cdot 6$ & $-5 \cdot 0$ & N. & \\
\hline $13 \cdot 3 \cdot 32$ & 0 & 0 & 0.0 & $6 \cdot I$ & 0.0 & ESE. & \\
\hline 14.2 .32 & 0 & 0 & $\mathrm{~T}$ & $10 \cdot 5$ & $2 \cdot 6$ & E. & \\
\hline $16.3 \cdot 32$ & 0 & 0 & $0 \cdot 0$ & $9 \cdot 4$ & $-2 \cdot 6$ & E. & \\
\hline $17 \cdot 3 \cdot 32$ & 0 & 0 & 0.0 & $6 \cdot I$ & $-\mathrm{I} \cdot 7$ & NE. & \\
\hline 18.3 .32 & 0 & 0 & $\mathrm{~T}$ & 4.4 & $\mathrm{I} \cdot 7$ & N. & \\
\hline $19 \cdot 3 \cdot 32$ & 2 & 0 & $\mathrm{~T}$ & II I I & $I \cdot 7$ & NW. & \\
\hline $20.3 \cdot 32$ & 0 & 0 & $\mathrm{~T}$ & $12 \cdot 9$ & $I \cdot 7$ & W. & \\
\hline 21.3 .32 & 9 & $\mathbf{I}$ & $\mathrm{T}$ & II $\cdot 7$ & $4 \cdot 4$ & S. & \\
\hline $22.3 \cdot 32$ & 0 & 0 & $9 \cdot I$ & $7 \cdot 7$ & 0.5 & WSW. & \\
\hline $23 \cdot 3 \cdot 32$ & 4 & Io & $I \cdot O$ & 10.5 & 0.5 & Calm & Croydon, SSE. \\
\hline $28 \cdot 3 \cdot 32$ & 0 & 3 & $0 \cdot 3$ & $12 \cdot 9$ & $4 \cdot 4$ & SW. & \\
\hline $29 \cdot 3 \cdot 32$ & I & 4 & $9 \cdot 0$ & $10 \cdot 5$ & $5 \cdot 6$ & SSW & \\
\hline $30.3 \cdot 32$ & 0 & I & $I \cdot 3$ & $12 \cdot 2$ & $5 \cdot 0$ & SW. & \\
\hline $31 \cdot 3 \cdot 32$ & 0 & 2 & $I \cdot O$ & I $2 \cdot 2$ & 0.5 & SW. & \\
\hline I0.3.33 & I & 3 & $0 \cdot 0$ & I $2 \cdot 9$ & $3 \cdot 3$ & E. & \\
\hline I $5 \cdot 3 \cdot 33$ & 0 & 0 & $2 \cdot 0$ & $10 \cdot 0$ & $6 \cdot 1$ & S. & \\
\hline $7 \cdot 3 \cdot 34$ & 0 & 0 & $0 \cdot 0$ & $8 \cdot 3$ & -0.5 & W. & \\
\hline $9 \cdot 3 \cdot 34$ & 0 & 0 & $0 \cdot 3$ & 10.5 & $2 \cdot 2$ & SSE. & \\
\hline II. 3.34 & 0 & 0 & $8 \cdot 5$ & $8 \cdot 8$ & $2 \cdot 6$ & SSW & \\
\hline 12.3 .34 & I? & I & 0.5 & $6 \cdot 1$ & $3 \cdot 3$ & W. & \\
\hline I $3 \cdot 3 \cdot 34$ & 3 & I & $7 \cdot 5$ & $7 \cdot 2$ & 0.5 & NNW. & \\
\hline $14 \cdot 3 \cdot 34$ & 6 & 5 & $6 \cdot 0$ & $6 \cdot I$ & $2 \cdot 2$ & SSE. & \\
\hline I 5.3 .34 & $\mathbf{I}$ & 0 & 0.3 & $9 \cdot 4$ & $\mathrm{I} \cdot 7$ & SW. & \\
\hline I6.3.34 & I3 & 8 & $2 \cdot 8$ & $8 \cdot 8$ & $1 \cdot 7$ & & \\
\hline I 8.3 .34 & 0 & I & 0.0 & $9 \cdot 4$ & 0.5 & WSW. & \\
\hline 19.3 .34 & 0 & 0 & 0.5 & $7 \cdot 7$ & $4 \cdot 0$ & S. & \\
\hline $20.3 \cdot 34$ & & & $10 \cdot 0$ & $6 \cdot 6$ & $2 \cdot 6$ & N. & \\
\hline $21 \cdot 3 \cdot 34$ & 0 & I & $0 \cdot 0$ & $6 \cdot 1$ & $-I \cdot I$ & NW. & \\
\hline 22.3 .34 & 0 & 0 & $0 \cdot 0$ & $10 \cdot 0$ & 0.0 & NW. & \\
\hline $23 \cdot 3 \cdot 34$ & 0 & 0 & 0.0 & $10 \cdot 0$ & $I \cdot I$ & Calm & Croydon, NW. \\
\hline $24 \cdot 3 \cdot 34$ & 3 & 9 & $5 \cdot 0$ & $9 \cdot 4$ & $6 \cdot 6$ & SW. & \\
\hline $25 \cdot 3 \cdot 34$ & 0 & 0 & $0 \cdot 0$ & $13 \cdot 3$ & 0.5 & E. & \\
\hline 26.3 .34 & 0 & I & 0.0 & $\mathrm{Ir} \cdot 7$ & $4 \cdot 4$ & SSW. & \\
\hline $29 \cdot 3 \cdot 34$ & 0 & 0 & 0.0 & $6 \cdot 1$ & 0.5 & E. & \\
\hline $30.3 \cdot 34$ & 0 & 0 & $0 \cdot 0$ & $7 \cdot 7$ & 0.5 & E. & \\
\hline $2.4 \cdot 34$ & 0 & 0 & 0.0 & 10.5 & $I \cdot 7$ & N. & \\
\hline $4 \cdot 4 \cdot 34$ & 0 & I & $0 \cdot 0$ & $6 \cdot 6$ & $I \cdot I$ & N. & \\
\hline
\end{tabular}


I4th March, 1934, was a migration night, but the same date in 1932 was not. In 1934, there was much rain, but if rain was the cause of the difference, it is not clear why the 21 st March 1932 showed such a great amount of migration, because, as on the r 4 th, there was only a trace of rain. When we come to wind direction, we secm on firmer ground. The I4th, I9th and 20th March I932, all warm days, had winds with little or no south in them. On the 2 Ist the wind turned south, and there was a great migration. In 1934 the pre-spawning period was marked by three northerly winds and a calm. The 2oth, a night when there was very little migration, was pouring with rain and mild, but the wind was due north. In I93 I there was a great migration on the night of the I9th March. The weather was warm, but dry. Wind was east-south-east. I do not suggest that there is no connexion between wet and warm nights and migration, for there is a loose correlation, but in the case of the frogs visiting Large Totteridge it seemed to be necessary that the wind should be in the south for migration over the road to be extensive, and this is just what the smell hypothesis requires.

In the following paragraphs, I give a more formal analysis. The argument is statistical in character, and it is impossible to relegate all of it to Chapter Io, Appendix I $g$, where, however, more details will be found.

In the paper, I pointed out that there was a significant tendency for the frogs to migrate when the wind was blowing from a southerly direction, across the pond to the road where the animals were killed, but I qualified this by pointing out that this was not very good evidence for migration up-wind. This was, indeed, the expected direction for a migration directed by smell, but winds from this direction are often wet and warm. I said that the unravelling of this kind of data would need more information than was then available. This is only partly true, and I now think that I was not sufficiently enterprising in the analysis, and too cautious in the conclusions.

In Fig. 26, wind frequency and direction is compared with migration and wind direction, the same scale being used for each. It is obvious that most of the migration occurred when the wind was from the southerly directions. In Table 6 the same data are arranged in Columns I and 2, and in Column 3 are shown the amounts of migration that would be expected if migration had been at random, and so merely in proportion to the frequency of the winds at the period studied. It is obvious that there was a large surplus of frogs migrating 


\section{WIND}

NNW N NNE

NW

NE

WNW

w

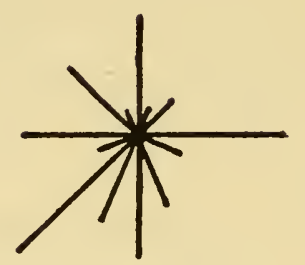

ENE

E

WSW

sw

SE

SSW SSE

S

\section{MIGRATION}

NNW N NNE

NW

NE

WNW

ENE

w

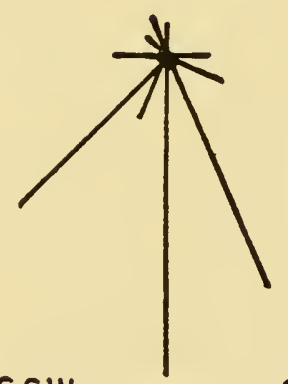

S SW

s

SSE

ESE

WSW

sw

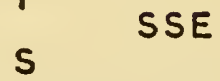

FIG. 26. Wind Direction and Migration to Large Totteridge over the Road

The wind diagram shows the frequency of the winds over the period, the length of the lines being in proportion to the frequencies at each direction. Note that there were no south-east winds in this period. The migration diagram shows, on the same scale, the amount of migration, that took place when the wind was blowing in the indicated direction. If these frogs had migrated at random, this diagram would be the same as the wind diagram. It is clearly quite different, showing a large excess of migration when the wind was in the southerly direction, that is, blowing across the pond to the road. 
when the winds tended to be southerly. Tested by the usual methods, the conclusion is very highly significant (Chapter ro, Appendix I $g$ ).

The next step was to fund out what relation, if any, existed between tempcrature and rainfall, as weather factors, and migration. The linear corrclation coefficients in each case were just over 0.20. For

TABLE 6

THE RELATION OF MIGRATION TO WIND DIRECTION AT TOTTERIDGE

\begin{tabular}{l|c|c|c}
\hline Wind & Frequency & Migration & $\begin{array}{c}\text { Migration Expected } \\
\text { if it had becn } \\
\text { Random }\end{array}$ \\
\hline N. & 5 & 3 & $11 \cdot 7$ \\
NNE. & I & 0 & $2 \cdot 5$ \\
NE. & 2 & 0 & 4.8 \\
ENE. & 0 & 0 & 0.0 \\
E. & 6 & 4 & $14 \cdot 1$ \\
ESE. & 2 & 6 & 4.8 \\
SE. & 0 & 0 & 0.0 \\
SSE. & 3 & 25 & $7 \cdot 2$ \\
S. & 5 & 32 & $11 \cdot 8$ \\
SSW & 4 & 7 & $9 \cdot 5$ \\
SW. & 7 & $2 \mathrm{I}$ & 16.5 \\
WSW. & 2 & I & 4.8 \\
W. & 5 & 6 & 11.8 \\
WNW. & 0 & 0 & 0.0 \\
NW. & 4 & 3 & $9 \cdot 5$ \\
NNW. & I & 4 & 2.5 \\
\hline
\end{tabular}

47 pairs of varieties, these are not significant. It is, however, possible that this is due to the small number of observations. If this value were to be maintained in a larger number of observations, as is quite possible, it would still show that the influcnce of rain and temperature could only be small, for the square of the corrclation cocfficient is a measure of the proportion of the total variance accounted for by these factors. We cannot expect that these factors are major influences when each only accounts for some 4 per cent of all the influences at work. Since it is often thought that warm rain influences amphibians more than cold rain, there was a possibility that a joint function would show a higher correlation, so that another correlation was computed using the product of rain and temperature as the variable. This gave a result very little better at $0 \cdot 23$. It is probably unwise to press this result to the conclusion that, in migration, temperature and rainfall are merely additive factors, and do not act jointly as is usually supposed, but that is where the statistics lead. 
Since the relationship with wind direction was obviously curvilinear, a further attempt was made on the problem by a multiple curvilinear correlation method, using temperature, rainfall and wind direction as the independent variables. The result was unsatisfactory, for early in the analysis it became obvious that these variables were only minor factors. The value of including the results here can be questioned, and is discussed in Chapter ro, Appendix I $g$, but after considering their suppression, I decided that, poorly based as they are, they may be the best so far available. Fig. 27 shows the curves obtained by the analysis. The rainfall curve suggests that once there is a certain amount of rain, more has no effect on migration, but it may be that the effect shown really measures the probability that it is raining at the time of migration. Light rain may have fallen in the morning only, but heavy rain very likely goes on all day and into the evening. The temperature curve shows no sign of a threshold value. It is common to read in accounts of amphibian behaviour some statement to the effect that "Activity has never been seen below a temperature of $x^{\circ}$." It is doubtful if such statements have any real value. If a curve such as that in Fig. 27 expresses the results, then activity will get more and more rare the lower the temperature, but there may be no real end-point at all. The supposed limit will then merely depend on the quantity of experience brought into the discussion. For example, in this figure no migration is recorded below $\mathrm{I}^{\circ} \mathrm{C}$, but I have seen frogs migrating in a snowstorm, and there is a record of them migrating over the snow in the Pyrenees (Wolterstorff, 1904). There is presumably some point at which movement stops, but it is probably not much above freezing point, and the attempt to find the lowest point of a curve nearly asymptotic to the axis is not likely to be rewarding. We may be looking at the tail of a distribution curve, in which the probability of finding a migrating frog at decreasing temperatures gets lower and lower.

It is possible that the reason for the difficulties in the analysis was that the main cause was not in the data under examination, but it could be merely because only a small part of the migration-that over the road-was being considered. Migration goes on for a long time, often for weeks, and if movement from the winter quarters goes on when wind, temperature, and rainfall are suitable, it does not at all follow that frogs from a long way away will reach the road on that night. On the other hand, if a large number do get near the road, but are halted by daylight before they cross the road, they may complete 

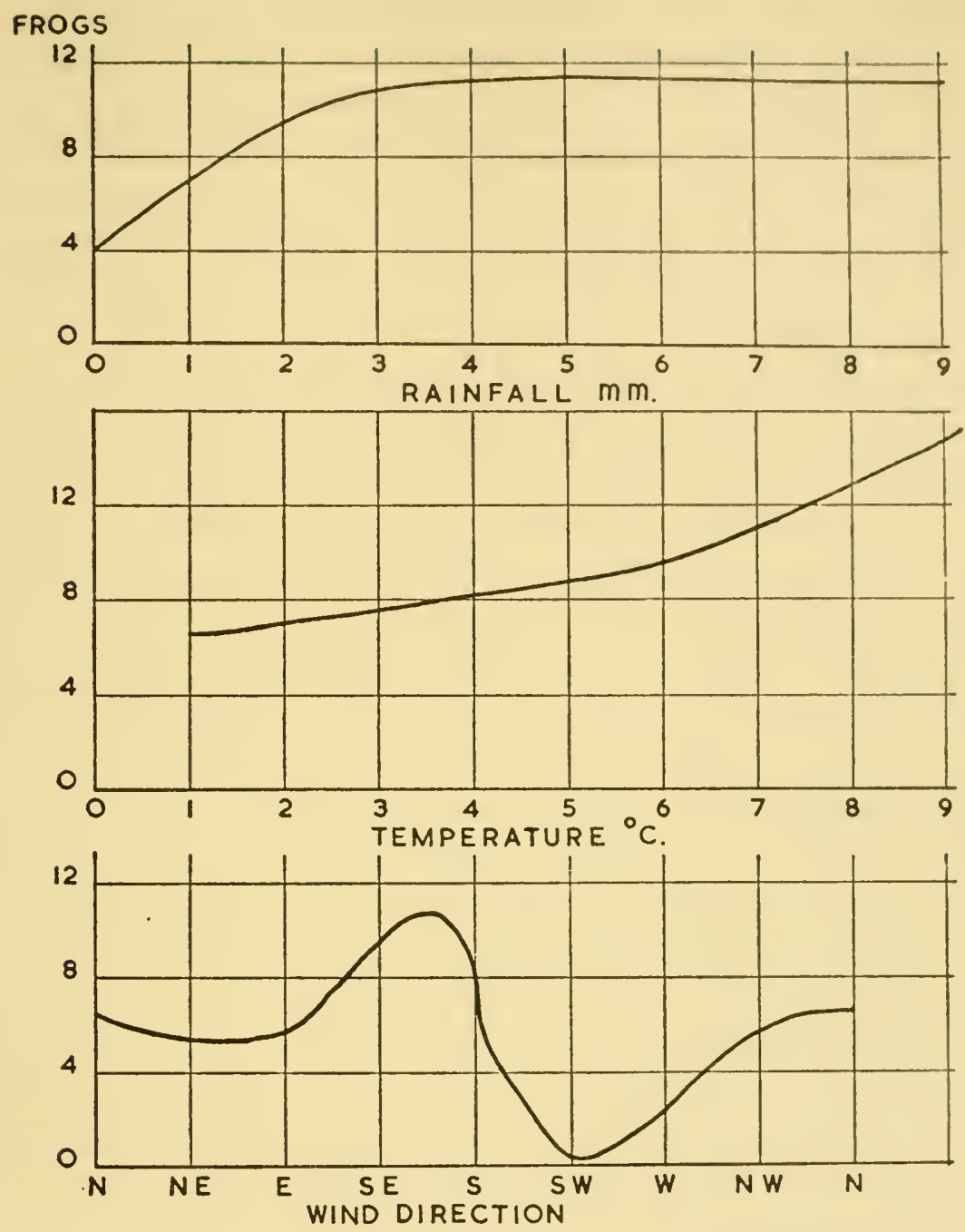

FIG. 27. Net Regression Curves of Migration on Rainfall, Temperature and Wind Direction

No high accuracy is claimed for these curves, but they probably represent the facts reasonably well. The minimum in the wind direction curve is due to the removal of the temperature and rainfall effects. Winds in this quarter are commonly wet and warm, and some of the migration was apparently due to these factors. Note that the removal of the other factors has not altered the predominance of the southerly migration, but has merely shifted the maximum slightly to the east. It seems impossible to ascribe migration over the road to rain or high temperature. 
the journey on a night when the conditions are not favourable. The effect of this on the data will be large, and just what would result in a poor correlation. If we had a complete picture of migration, it could easily happen that these three factors turned out to be much more important. Blanchard (1930) showed that, in the breeding migration of the Spotted Salamander, Ambystoma maculatum, the animals arrived at the pond in successive waves, according to the place in which they were hibernating.

It is impossible to account for the observed association of migration with southerly winds by the hypothesis that the relation is due to the well-known association of warm and wet weather with winds from the south, although in the 1935 paper I raised this objection myself. The most favourable condition for this hypothesis would be complete correlation between these factors. In such an unlikely event, there would be a state of contradiction between the high association of wind direction with migration, and the low correlation with rainfall and temperature. With any lower correlation between wind and weather, the hypothesis would be even less tenable. I do not find it possible to dismiss the evidence, at this particular pond, for migration just as the smell hypothesis would require. It is unfortunate that no other suitable opportunity has occurred to repeat the observations in some quite different place, for I still doubt whether, in some places with a different topography, wind would be so important, and feel that other air currents may play a large part. My pond was situated in a rather simple place, near the summit of one of two smooth parallel ridges, and I should not expect much disturbances of the general direction of the wind.

I have now tried to convey a picture of migration. Nothing can quite replace actual observation of this purposeful movement of determined frogs. No one who has witnessed it can believe it to be due to haphazard wandering over the countryside. In the more general discussion which now follows, we can safely discard any idea that the frogs merely come across their ponds by accident.

Several have suggested that the animals find their ponds by going downhill. This will not do at all, for frogs do not always go downhill to the ponds, and ponds are often on the tops of hills. It is streams that run at the bottom of hills, but this species does not usually breed in streams.

Hydrotaxis, the ability to move towards water at a distance, is 
another suggestion, but it cannot be seriously considered. Orientation always requires that there should be a difference between different parts of the field. Now, during rain, the whole country is wet-just as wet as the ponds-so that an animal using hydrotaxis as a guide would lose its direction. But this is just the time when migration secms most likely to occur, and the animals show no sign that they have lost their way. Chapman and Chapman (I958) came to a similar conclusion in their study of the African Lcopard Toad, B. regularis, and rightly point out that migration from one pond to another shows that hydrotaxis cannot be important, citing Breder, Breder and Redmond (I927) and my paper of I935. To these examples can be added Juszczyk (I95I) on $R$. esculenta and Martof (I953) for $R$. clamitans.

Since frogs have voices, it is natural that there should be many suggestions that these are used to attract other frogs to a pond in which there is at least one already. This was the view, for example, of Noble (I93I), and Bogert (I958) came to the conclusion that although there were some inconsistencies, it was probably true that voice plays a part in guiding frogs and toads to their ponds. But Cummins (I920), who having camped beside an American pond for six weeks for the special purpose of observing migration, should certainly know about the species there, thought that voice played a minor role. He made small catches on nights when there was much croaking, and large ores when there was little. The remarkable experiments of Bogert (1958) must be mentioned here. The Southern Toads, B. terrestris terrestris, were tested for their reactions to the voices of their own species played back to them from a tape-recorder. Females on the whole moved towards the instrument, but males often moved away from it.

It is, however, necessary to take account of the species concerned. Many of the American species have very loud voices-in fact the noise arising from the ponds there has been described as deafening. In Europe, too, there are noisy frogs. Among the causes of the French Revolution, the noise of frogs, probably R. esculenta or Hyla arborea, was possibly one. The nobles forced the peasants to beat the ponds all night so that in the château near by, sleep would be possible. English people are not used to this kind of thing from either nobles or frogs. $R$. temporaria has a very quiet voice, and even a large colony can usually not be heard more than, say, fifty yards away. Now, this is not likely to be due to any insensitivity of the human ear. We have very good ears (and very good eyes, too), so good that we can perceive a few 
quanta of light and sound energy - that is near the limit of the physically possible. We may often be inattentive to noises and sights of no importance to us, as other animals are, but in favourable circumstances, what we cannot see or hear is probably invisible or inaudible to other animals. It has been shown above that there is conclusive evidence that, in $R$. temporaria, migrations can go on in complete silence, so that we may eliminate the sense of hearing as a possible guide for migration.

Sight, of course, is out of the question, A frog has eyes only an inch or so above ground level, and in the rough country over which it usually migrates, its horizon must be limited to a few yards.

Of the known senses capable of acting at a distance, there is now only one left: the sense of smell. But, before I deal with this specifically, I must answer a criticism that may well be rising in the reader's mind. A great deal of work has been done on migration in other animals, and there are still very many obscure points. We have to admit that we often have very little idea of the clues that animals use to find their way. It does seem, however, that things are getting a little clearer. In the now classical case of bees, we know that elaborate social instincts are combined with navigation using the sun. In birds, too, there is an increasing probability that astronomical navigation aids are used, much as we do at sea or in the air. It is noteworthy that in these cases what has been discovered is not some new organ of navigation or some special sense or some new clue, that we did not know existed, but the means by which the animals use those senses and existing clues we knew were there all the time. We stand amazed at delicacy, precision and resources unimagined before, but it is familiar all the same. I feel, therefore, that before we invent some special pondfinding sense, or give up the problem as beyond the reach of any hypothesis so far suggested, we ought to exhaust the possibilities of the known senses. There is now only one left: does it fit?

It will be remembered from the last chapter that frogs prefer one pond to another, do not spawn in every pond and that ponds with frogs in one year may have none in the next. There is evidently something specific, yet temporary about a frog-pond. What property is there that is specific, temporary, and can be perceived at a distance? It is quite certainly not water, for that is common to all ponds and at times to much of the land as well. Can it be that the salts in the water, which I have shown to be associated with the preferences of frogs, are 
perceptible at a distance? Except for perhaps carbon dioxide, hydrogen sulphide and ammonia, the inorganic components of pond water are not volatile. Carbon dioxide is so common, and is produced by the frogs themselves in far larger quantities than could be present in the emanations from a pond, that it can surcly be climinated. I doubt whether hydrogen sulphide is given up to the air from normally oxygenated ponds, for, in balanced aquaria, lead cements darken below the sand line, but not above it. Ammonia is surely out of the question, not only because it is probably not evolved, but because, if it were attractive to frogs, they would be drawn to manure heaps instead of going to the ponds. So it seems that we must look to organic compounds for any possible stimulus.

Czeloth (1930) was probably wide of the mark when he suggested marsh gas as a guide to the migrations of the newts he was studying, but much nearer when he mentioned water plants, for it is these that impart the characteristic odour to pond water. It is, however, not the higher plants that do this, but the algae. There is much information on this matter, for it is of economic importance. If certain specics of algae grow in drinking-water reservoirs to too large an extent, the consumers complain that the water tastes or smells. The odours are not always unpleasant, but people do not like water that has a strong smell or taste, whatever it is. The odours are due to essential oils elaborated by the algae, and the smells are so characteristic that a skilled person can detect and identify the species of alga sometimes before it can be located under the microscope. I once detected a smell from a pond (Large Totteridge) many yards from the bank, and suspected from the textbook description that it was due to Synura uvella. Microscopic examination showed that this species was abundant in the water.

The fit of this hypothesis with most of the facts in the field is very good. The smells are found in ponds-nowhere else in the whole countryside. Any particular smell is probably only found in a few ponds for there are so many species of algae that, in a linnited area, there are hardly any two ponds with the same flora. Ponds tend to have the same species in successive years, but this is not invariably so. The plants are, of course, greatly influenced by the mineral salts in the water: it will be recalled that potassium and phosphate, both important plant nutrients, are associated with the preferences of frogs. I shall show in the next chapter that the variation of the spawn date follows a statistical pattern that is similar to that shown by aquatic 
plants. It is different from anything I can attribute to a direct influence upon frogs.

In my own studies of migration in $R$. temporaria, I found that the animals moved mainly up wind and uphill, and I had no reason to doubt that wind and probably convection currents were acting according to the hypothesis. But workers on other species have not had the same experience. Moore (1954), working on B. bufo, found that some migration took place with the wind, and was often downhill, and Chapman and Chapman (1958) came to the same conclusion about $B$. regularis. I am, however, not at all satisfied that we yet know enough about the movements of air at the places that matter, namely at ground level or even below it, to consider that movement down wind necessarily denotes that the animals are not guided by smell. In the I935 paper, I pointed out that Giblett (1932) had shown that when wind blows over level country with obstructions, eddies are produced with their axes in all directions and with diameters comparable with the size of the obstructions. It is, after all, a common experience to be buffeted by the wind as one walks along, the blows often coming from unexpected directions.

Moreover, migration often takes place over rough herbage, and I do not think that the movements of air under such cover bears any necessary relation to the direction of the wind as shown on a weathercock perhaps fifty feet from the ground. Budgett (1933) used smoke bombs to study the movements of air near the ground, and found that, even in a gale, smoke often travelled in the opposite direction to the wind. He was investigating the effect of weather on scent in hunting, and concluded that good conditions occurred when the earth was warmer than the air just above it. He showed that under these conditions air currents came out of the ground, but, when the temperatures were reversed, the air sank into the ground. Although he did not mention the point, which was not important to him, it seems necessary to assume that upward air currents must be accompanied by some horizontal movement of air through the upper layers of the soil. Veryard (1935) also studied hunting conditions, and did not agree with Budgett, considering that the favourable conditions were low adiabatic lapse rates, or even inversions, for these tended to prevent the dispersal of eddies.

Both authors, it should be noted, concerned themselves mainly with air currents and not with wind. This is undoubtedly a very 
complicated matter, which needs more study, and I feel that it is an over-simplification to pay attention only to wind, which may not exist in the important place. It should also not be overlooked that in my studies there was a significant correlation with wind direction, even though I refused to consider that this was the whole story.

In my observations, I found that frogs tended to follow ditches even if these were dry, and I suggested that the animals were following the lines of air drainage at night, when it is common for air to flow from the tops of hills, where my pond was situated, to the valley below. Moore (1954), in his study of $B$. bufo, found that many toads came down from the hills to his pond in the valley, following particularly the sunken roads. A map of the district shows that the pond was almost surrounded by hills, with narrow outlets to the lower country some distance away. It is interesting to speculate on the effect of a layer of cold air at hilltop level. It seems possible that air currents from the warmer valley floor might indeed pass up the deeper parts of the side valleys, being pushed up by the denser air above. There is obviously much that we do not yet know about amphibian migration or the fine structure of air in a complex situation. Many different facts suggest that smell is the guide, and there is nothing known against the hypothesis, except this matter of wind direction in some circumstances, which may be after all wrongly based. No reasonable alternative has been suggested, but this does not add up to proof.

\section{The Stimulus for the Beginning of Migration}

What is it that starts the frogs on the migration? Before we seek the answer to this question, it seems necessary to consider whether the stimulus of migration is the same as the stimulus that initiates brceding, once they have reached the ponds. I think that in the description of the events I have just given, there is evidence that the two may be different. In some years, the frogs breed as soon as they arrive. If this always happened, it might be very difficult to distinguish between a migration and a breeding stimulus. But it does not always happen. In some years, frogs begin to migrate for weeks before they breed, and although animals of both sexes are in the ponds, there is no sign of the definite breeding behaviour until, as if at a signal, this starts in full vigour. This must surely imply that the stimuli are different, and the most probable explanation of breeding immediately on arrival is that when two separate events take place near in time, there will be 
occasions when by chance the dates will coincide. As I shall show in the next chapter, we now know much about the nature of the spawn stimulus itself. We do not know nearly as much about the migration stimulus.

It seems likely that a certain level of hormones is necessary for migration, but there are always serious difficulties in accepting this kind of explanation when synchronous behaviour is involved. It is quite clear that the animals live during the autumn and winter under different temperature conditions. For example, the frogs at Hibernating Pond were not all in the water; some were in crevices in the bank. In general, there is no doubt that the population of frogs in this area was using a multitude of hibernacula. Now the generation of hormones is a biochemical reaction, and it would be a most amazing thing if the process had no temperature coefficient. Since frogs are poikilotherms, the process must be proceeding at different rates in different frogs, unless all are living at the same temperature.

In the absence of any knowledge about it, let us suppose that the beginning of the process is at the date when the frogs begin to hibernate, say in October, and that hibernation begins simultaneously in the whole population (a very unlikely assumption in itself). Then for the final stage of stimulation to occur within three weeks, some four months later, we would have to assume a rate of reaction correct to about \pm 8 per cent. This is quite good for a biochemical reaction in a laboratory thermostat: it is quite incredible for one occurring in hundreds of frogs at liberty in the field. In this, as in other similar cases, it must surely be that the hormones merely provide a part of the mechanism that transmits some effect in the environment to the organs of the frogs. Hormones bear to the environment and the frog the same relation as a telephone system does to the telephone conversation. The physiologist is interested in telephone systems, the ecologist in the conversations. The whole phenomenon includes both, but no useful purpose is served by stretching ideas about hormones to cover ecological concepts. Sometimes, however, the synchronization of migration is not at all accurate. In I932, for example, I found some migration taking place two months before spawning, and, for a rough adjustment of this kind, perhaps nothing more than a physiological explanation is necessary, but it would be rash even then to suppose that the full explanation is as simple as a reaction rate.

Although I have suggested that the guide for migration is different 
from that for breeding, it is quite possible that they are of the same typc. For example, frogs might be guided to the pond by one olfactory stimulus that began to be obvious at the beginning of migration, but, once there, might wait until another olfactory stimulus sets them breeding. After all, a woodpecker secking a nesting hole must first of all find a tree, and before that a wood, very likely seen from so far off that neither tree nor hole would be visible. These are three different stimuli, but all of the same type. Frogs on migration enter the pond at the point where they happen to be when they reach it. Only after they are in the water do they gather at the spawning site. I concluded from this that recognition occurred in that order-first the pond, perceived from afar, then the site, perceived only in the water.

\section{The "Poikilothermous Effect"}

It is unfortunate that zoology is burdened with a special term to describe what is commonly included under the simple term "coldblooded," but there is no other convenient way of describing events in an animal when its blood is not particularly cold, but has merely varied with the temperature of the environment, in contrast with homoiotherms, whose blood keeps at a constant temperature whatever the temperature of its surroundings.

In this chapter and in the next two, the activities of frogs under different temperature conditions are described. In several places, I have thrown doubt on the high importance attached by most authors to temperature. This is sometimes because analysis of the figures does not support the assumptions, but partly for a different reason, in which the meaning of words plays a part.

We ourselves are homoiothermous animals. We live, as it were, in a thermostat of our own, adjusted to $37^{\circ} \mathrm{C}$, whatever the outside temperature, so long as we are in normal health. Physiological events in our bodics are not at the mercy of fluctuating temperatures, and take place on the whole at constant speeds. In the world of a poikilotherm, everything gocs faster in hot weather. The animals cat more, excrete more, their hearts beat faster, their muscles contract more quickly and so on. There is probably nothing in their bodics that does not act more quickly when the temperature is high. They have a different time scale from ours, for more things happen in an hour on a hot day than on a cold one. It would not do for a poikilotherm to use an ordinary clock. 
Imagine an industrial society of poikilotherms, say frogs. On a cold day, a factory would scarcely work at all. On a warm morning, crowds of energetic frogs would surge in and set to work with a will. The management would be hard pressed to provide enough materials from stock, or find food for the canteen. Telephone orders would help, for the frog drivers of vehicles would be able to rush supplies along safely, because their co-ordination of hand and eye would be much increased. The newspapers, of course, would not contain complaints about the inaccuracy of weather forecasts. Instead, indignant protests would be made that the meteorological services were not able to predict the number of work units in the daylight hours for more than a few days ahead, and even then were often wrong. Clocks, presumably, would have temperature-sensitive devices in them, instead of compensating arrangements to annul the effects of temperature, as we have in ours.

Now, what do we really mean when we say that, in frogs, croaking, migration or spawning goes on more in warm weather than in cold? Do we mean that one of these functions goes on faster than the others in the animal? This would be scientific news. So, undoubtedly, would be the discovery that some function went on at the same speed, whatever the temperature. But the mere observation that one function goes on more quickly at high temperatures than at low ones is not news-what else can we expect?

In the study of migration above, a temperature effect was reported. I doubt very much if this is anything more than the result of the general "poikilothermous effect," and is no more a "stimulus" to migration than raised temperature is a stimulus to digestion.

\section{REFERENCES}

Barthélémy, H. C. R. (I926) C. R. Acad. Sci. Paris, I82, I653-7.

Blanchard, F. N. (1930) Amer. Nat., 64, I54-67.

Bogert, C. M. (1958) Folkways Record Album, FX6I66 (New York).

Boulenger, G. A. (1897) The Tailless Batracians of Europe (Roy. Society, London).

Boulenger, G. A. (I912) Proc. zool. Soc. Lond., I9-22.

Breder, C. M., Breder, R. B. and Redmond, A. C. (I927) Zoologica N.Y., 9, 20I-29.

Budgett, H. M. (1933) Hunting by Scent (Eyre \& Spottiswoode, London).

Chapman, B. M. and Chapman, R. F. (1958) J. Anim. Ecol. 27, No. 2, 265-86.

Cotr, H. B. (1936) Proc. zool. Soc. Lond., I II-33. 
Cummins, H. (1920) J. exp. Zool., 30, 325-43.

Czeloth, H. (1930) Z. vergl. Physiol., 13, 74-163.

Dolk, H. F. and Postma, N. (I927) Z. vergl. Physiol., 5, 4I 7-44.

Fatio, V. (I 872) Faune des Vertébrés de la Suisse (George, Geneva).

Giblett, M. A. (1932) Geophysical Memoir, 54 (Meteorological Office, London).

Hecht, G. (1930) S.B. Ges. naturf. Fr. Berl., I6 December, 316.

Héron-Royer (1885) Bull. Soc. Etud. Sci. Angers, 92-1 34.

Juszczyк, W. (I95I) Bull. Int. Acad. Cracovie (Acad. pol. Sci.) 2, 34I-69.

Mailles, C. (I88I) Bull. soc. zool. Fr., 6, 23 I.

Martof, B. (1953) Ecology, 34, No. I, I65-74, 529-43.

MOORE, H. J. (I954) Brit. J. Herpet., I, No. II, I94-244.

Neal, R. R. C. (1956) Brit. J. Herpet., 2, No. 2, 15-23.

Noble, G. K. (I93I) The Biology of the Amphibia (McGraw-Hill, New York).

PARKER, E. (1934) Observer, London, 4 March.

Rovzewska, I. (I934) Observer, London, II March.

Savage, R. M. (1935) Proc. zool. Soc. Lond., 49-98.

SмIтH, C. L. (1949) J. Exp. Biol. 26, 4I2-29.

SMIth, M. A. (195I) The British Reptiles and Amphibians (Collins, London).

Veryard, R. G. (1935) Not seen, Ref. Nature, Lond., I 3 July.

Wolterstorff, W. (1904) Zool. Anz., 28, 536-8.

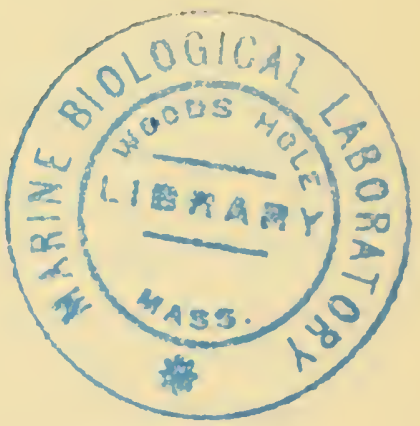




\section{Chapter 8}

\section{THE INFLUENCE OF EXTERNAL FACTORS ON THE SPAWN DATE}

IN dealing with the relation between the spawn date and the environment we enter a field that is bound to be complicated. It is my task to present this to the reader as clearly as I can, but, if I am to do justice to the subject, I cannot simplify it by leaving out the complicated parts. We cannot appreciate delicate detail while we are walking rapidly past it, and no picture of it painted in a few bold strokes can possibly convey what is there. My role, then, is to act in the way that a spectator who has been there before would do to a stranger, and to point out the intricate tracery of a frog's life, interwoven with the environment, for that surely is what will appear in the following pages.

It is an illusion to consider that a statistical treatment of this subject is optional. No human mind can disentangle such a web of interacting factors without the aid of statistics, and the obscurity surrounding the subject until these methods were applied was due undoubtedly to attempting the impossible. In this chapter, therefore, I include as much statistical matter as I think necessary to explain what has been done, but consign technical details to Appendix I $h$, in Chapter Io.

The breeding cycle of Amphibia, as in other animals, is under the immediate control of hormones, which are themselves regulated by those of the pituitary. In choosing for the title of this chapter a phrase that included the word "external," I deliberately excluded such influences. In my view, they are the conducting mechanisms, the telephone apparatus, but not themselves the autonomous initiators of breeding behaviour. Beach (1948) has stated the matter thus: "Hormones may be considered as internal stimuli or as part of the internal environment. In either case they are seen to be only one of several factors that operate in conjunction to produce a particular pattern of behaviour. In the absence of additional influences, particularly in the case of stimuli of external origin, hormones are powerless to affect behaviour." Six years later, Smith (1955), in a Symposium on the Comparative Endocrinology of Vertebrates, said in his paper on 
reproduction in female amphibia: "The general impression is that a complex pattern of external stimuli is necessary to induce clasping and ovulation...." How complex this pattern is will be shown in this chapter.

It is perhaps worth noting, before leaving the endocrinological aspects, that almost all the experiments of the endocrinologists have been concerned with the effects of temperature. It seems doubtful if much progress will be made until more attention is paid to the factors that field observations have shown to be important. Otherwise, much time can be spent in a search for a link between the environment and the gonads in places where it does not exist.

If Beach and Smith are right, as I think they are, we may perhaps suppose that the gonads and level of the hormones are under the rough control of a seasonal influence, which may be mainly temperature. Nothing more accurate than this is needed to bring the animals into breeding condition at about the right time, and indeed, nothing more can be expected of this factor, which is a very rough guide to date. It is not nowadays considered that temperature is a likely regulator of breeding seasons, although before the work of Rowan in about 1926 (Rowan, 1938), it was the normal thing to attribute the onset of breeding in an animal to the rising temperature. The reason for this belief in the importance of temperature, which is still widely held, is obscure.

In the climate of the British Isles, the lowest temperature may occur in any of four months, and the highest in another four. The middle ranges characteristic of the spring may occur in any month of the whole year. An animal using temperature as a guide might therefore start to breed at almost any date. It is of course true, that in parts of the country where frogs breed in March or later, the temperature is tending to rise, so that warm days and sequences of rising temperatures often occur when the frogs breed. But this association is also characteristic of any event in the spring. For example, the Chancellor of the Exchequer emerges from No. I I Downing Street to read his budget on some date in April. Investigation would undoubtedly show that he tends to emerge on a day when the temperature is higher than it had been lately, and after a sequence of rising temperatures. The longer the investigation, the more certain would the conclusions become, because they are in fact true. But the Chancellor is as unmoved by temperature as he is by many other things.

There is no great difficulty in making allowances for such trends by 
statistical means and, indeed, no evidence not backed by statistics can be accepted, for we seem particularly liable to subjective errors when temperatures are concerned. As a casual speculation, I have thought that this is because we were evolved in a tropical climate and can live in temperate climates only because we wear clothes and have houses, so that we can maintain a tropical temperature next to our skins. We are very appreciative of the rise of temperature in the spring, and have a te. Jency to think that animals are too. They may, however, have been evolved in this climate, or even in a colder one, and so may be indifferent to those low temperatures normal at the date when they usually breed. It is a curiosity of the literature on this subject that the same authors who consider that rising temperature is a stimulus to spawning also remark on cases of the animal spawning in partly frozen ponds, events that are rather difficult to reconcile with one another. The matter was settled beyond reasonable doubt in the 1935 paper, and it is to this that attention must first be given.

The whole of the data comes from the Phenological Reports of the Royal Meteorological Society, which may be briefly described in the following paragraph.

Many years ago, this society began to collect the dates of a large number of natural events, such as the first arrivals of migrant birds, or the first flowering of certain plants. It was felt that plants and animals integrate the effects of the weather, and act as a kind of automatic indicator in which the weather and climate of an area are reflected in a property known as "earliness." A large number of voluntary observers collected the data on forms provided by the society, and once a year these were summarized and published. In this way, over the years, an enormous mass of data has accumulated. In I926, late in the life of the scheme, frog-spawn was added to it and, as soon as I could, I collected the data from the society, and began statistical work upon it. The results were published in 1935, and some of the conclusions were then so certain that they have not been reexamined in the much larger scheme completed in I958. On other points, I suggested that the data available in I935 were not enough, and the matter should be allowed to rest for about thirty years. This period never elapsed, for the society was unable to get support from other societies and felt itself unable to carry on alone. In fact, its very valuable work had gone on so long that biologists have enough material for years of statistical work. 


\section{The Effect of the Weather at the Time of Spawning}

During many walks over the fields, I became increasingly sceptical about the significance of any effect of the weather at the time of spawning. There were too many instances of frogs spawning in cold weather, and too many when they did not spawn when it was warm, and too many similar ponds in which, although they were near together, the frogs spawned at different dates. In order to provide sufficient data for statistical analysis by my own efforts, I should have had to observe for a very long time, and confirmation of my suspicions had to be deferred until I could analyse the Phenological data. It is perhaps important to point out that the doubts arose literally in the field-they were not the result of cxamining data.

The map, Fig. 28, should now be studied. In Phenological literature dates are counted from January Ist which is Day I. February Ist is therefore Day 32, and so on.

The earliest areas for spawning, with dates in January, occur only in two places: in the Dartmoor and Exmoor areas of Devonshire, with an extension into South Wales on the other side of the Bristol Channel, and in the South West of Ireland. Cornwall is slightly later, and has similar dates to the West of Wales, and the areas to the North of the earliest areas. An observer at Campbelltown, in the Kintyre Peninsula of Scotland recorded six successive early dates. Next in order are areas on the West coast of Lancashire, much of Southern Ireland, an area in Wales, and parts of Dorset. The West Midlands, South West England, a strip along the South-East coast of England, and an area over the Yorkshire Wolds and Moors, a small patch North of the Cheviot Hills, West Scotland as far as known, and North Ireland form fairly early spawning areas. The 70-day isophene (line of equal date) encloses a very large area, from almost the extreme South-East of England to the North of Scotland, with patches in North Ireland, as far as known. Late spawning areas, enclosed by the 80-day isophene, are: the Eastern Counties of England, the industrial areas, a patch in South-East Scotland, and two interesting patches to the south of both the Firths of Forth and Moray in Scotland. With the exception of an interpolated ring round the latest area of all, the 90-day isophene only appears in industrial Yorkshire. The black patch in North-West England deserves special attention. It is an area near Crossfell in the Pennine mountains. There the mean date is over roo.

This map can be easily interpreted in the light of the facts discovered 
in the rest of the inquiry, which must to some extent be anticipated. The dominant weather factor is rainfall. The British Isles is usually under the influence of weather systems coming from the Atlantic Ocean, with the result that places in the west of the country, especially

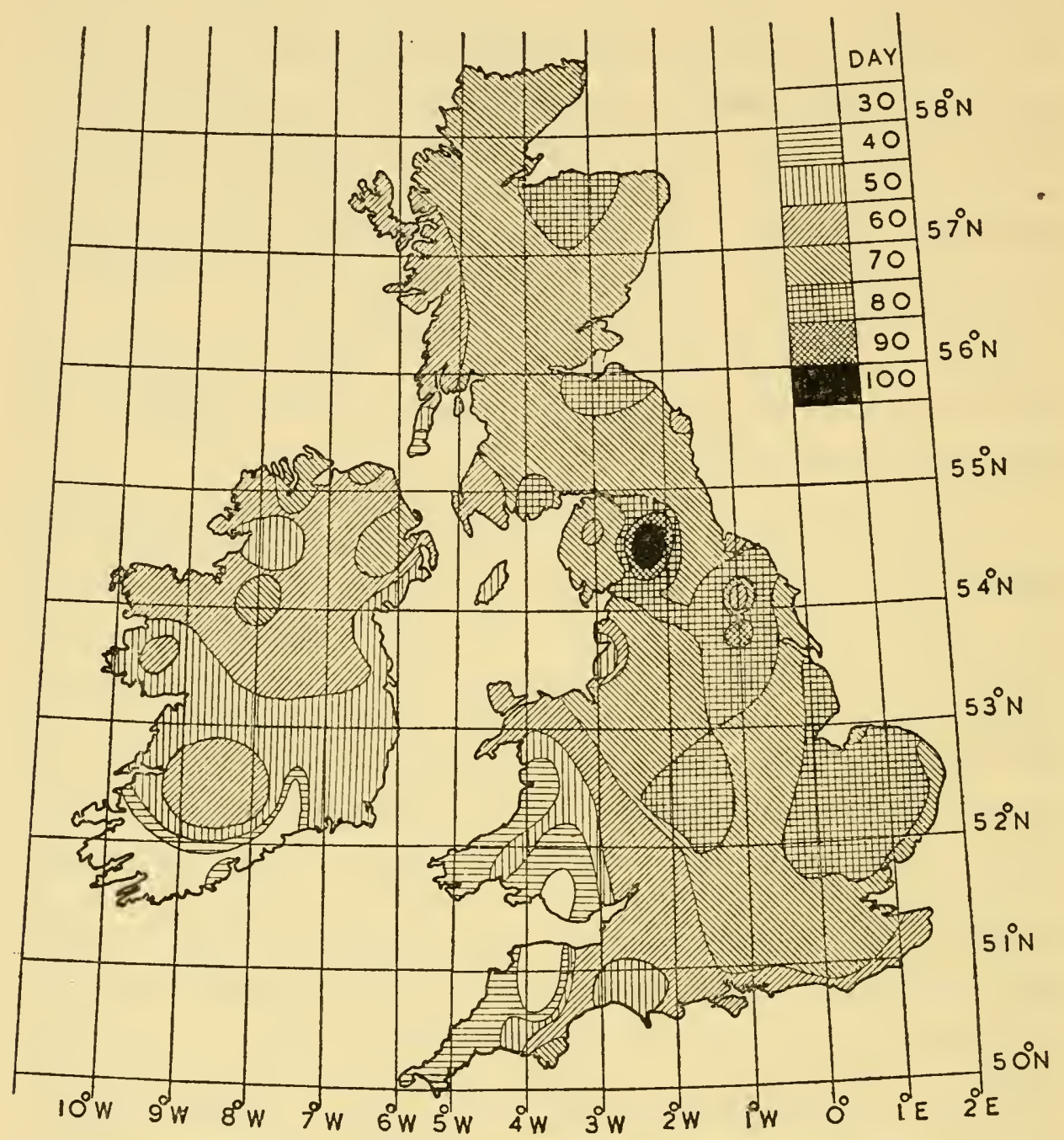

Fig. 28. Map Showing the Relation of the Date of Spawning to the Geographical Position

where hills provide orographical effects, are the wettest. These places can be picked out on the map, using only the frogs as a guide. Dartmoor, Exmoor, the coastal strip backed by the hills of South Wales, and the coastal areas of the West, are all represented. The Dorset heights, the Yorkshire Hills and even the small patch backed by the Cheviots, which interrupts the winds from the North Sea, all appear 
on rainfall maps as wet areas. Rainfall acts as an element of "run-off," the proportion of rain that is not evaporated and eventually reaches watercourses. It is interesting to see that the pervious soils of the South-East have hills, but that these are not early spawning areas. There is no sign of earliness in spawning over the North or South Downs, the Chiltern Hills, or the East Anglian Heights. There are no ponds on the Chalk itself, but this formation often has inlicrs of Drift, or patches of retentive clay, and frogs do occur in these areas.

Passing now to the late spawning arcas, we see that East Anglia is well known for its dry climate. Rainfall maps show patches of dryness to the south of the two Scottish Firths, just where the frogs indicatc. South-West Scotland is not very dry, so that the patch shown seems anomalous, as is the Thames Estuary, the driest part of the country, but not remarkably late. The Crossfell area is one of the most interesting. Besides rainfall, temperature is a factor, not in the short-term sense, but as a long-acting factor, especially important two months before the spawn date. This area has been investigated by Manley (1936) in a meteorological paper. He found that it had an exceptional climate. It is the bleakest inhabited area in England, and its winter climate resembles that of Iceland at sea level.

Ireland is interesting. The whole island is earlier in spawning than parts of England corresponding in latitude. The "Emerald Isle" is renowned for its rain, but the meteorological peculiarity is not so much the quantity of rain as its frequency, so that the ground is generally moist (Bilham, I938, p. IIo). It is when rain falls on dry ground that there is no "run-off."

It now remains to account for the lateness of the industrial areas. This can perhaps be attributed to the fact that, as will be shown later, light is a factor, and these areas have smoke palls. It is probable that all Lancashire east of the early area near the coast would also be early if it were not for the smoke, for in that county the early area in the west is not smoky, and in the more eastern areas, high rainfall counteracts the smoke and results in average dates. London is again anomalous, for it is a large and smoky city, but from the map it does not appear later than the country round it. It is often risky to attempt to explain such anomalies, but it does seem possible at least to suggest an explanation. London differs from the industrial North by being a concentrated area. It is, it is true, very large, but it is a unit, in which the inner areas are too thickly populated to have frog ponds at all, and 
the rate at which the smoke falls off in the outskirts is such that the neighbouring country is not very smoky. In the North, it is more usual to find industry in towns separated from another town by short stretches of country. From farmland in these areas, it is often possible to see industrial smoke on the horizon, in a way that does not often happen near London. As a speculative hypothesis, I suggest that the London anomaly is due to the absence of frog ponds where there is much smoke, to an extent that does not happen in the mixture of industry and farming in the North. In fact, my own area is one of the nearest to London that has records of spawning, and I find that the area just to the north, say five to ten miles away, is a little earlier.

From this wide survey of the conditions all over the country, let us turn to the other extreme, and examine the records, first of some interesting years in which the records within fifty miles of London were analysed in detail, and then, making use of some fortunate coincidences, to a few in other parts of the country where still greater detail was available.

In my opinion at the time, the number of records available in 1935 was not sufficient to justify the inclusion of those from the thinly populated parts of the country. I also felt that such complications as mountains and coastal areas would be better excluded. It was for these reasons that I confined most of the inquiry to results within fifty miles of London and used the weather data of Kew, at its centre. Kew is a First Order Observatory, one of the five in the whole country where every important element of weather is recorded at every hour of the day and night.

\section{Temperature}

One of the difficulties of dealing with this factor is that a circular argument can so easily be set up. Owing to the wide fluctuations in temperature that are normal at this season, it is usually possible to look back for a few days and find conditions as suitable as those considered necessary for spawning. The following colloquy can then occur-

Q. Why did frogs spawn on the 2Ist March 1929?

$A$. Because it was warm on that day.

Q. But it was warmer ten days earlier-why did they not spawn then?

$A$. Because they were not then physiologically ripe. 
Q. How do you know that?

$A$. Because, although it was warm enough, they did not spawn.

One has to break through this somchow.

If in a fairly small area with a climate that does not differ much from one part to another, one set of frogs spawn, it secms reasonable to suppose that the breeding season has begun. To assume after this date that some other set of frogs is not physiologically ripe is a form of

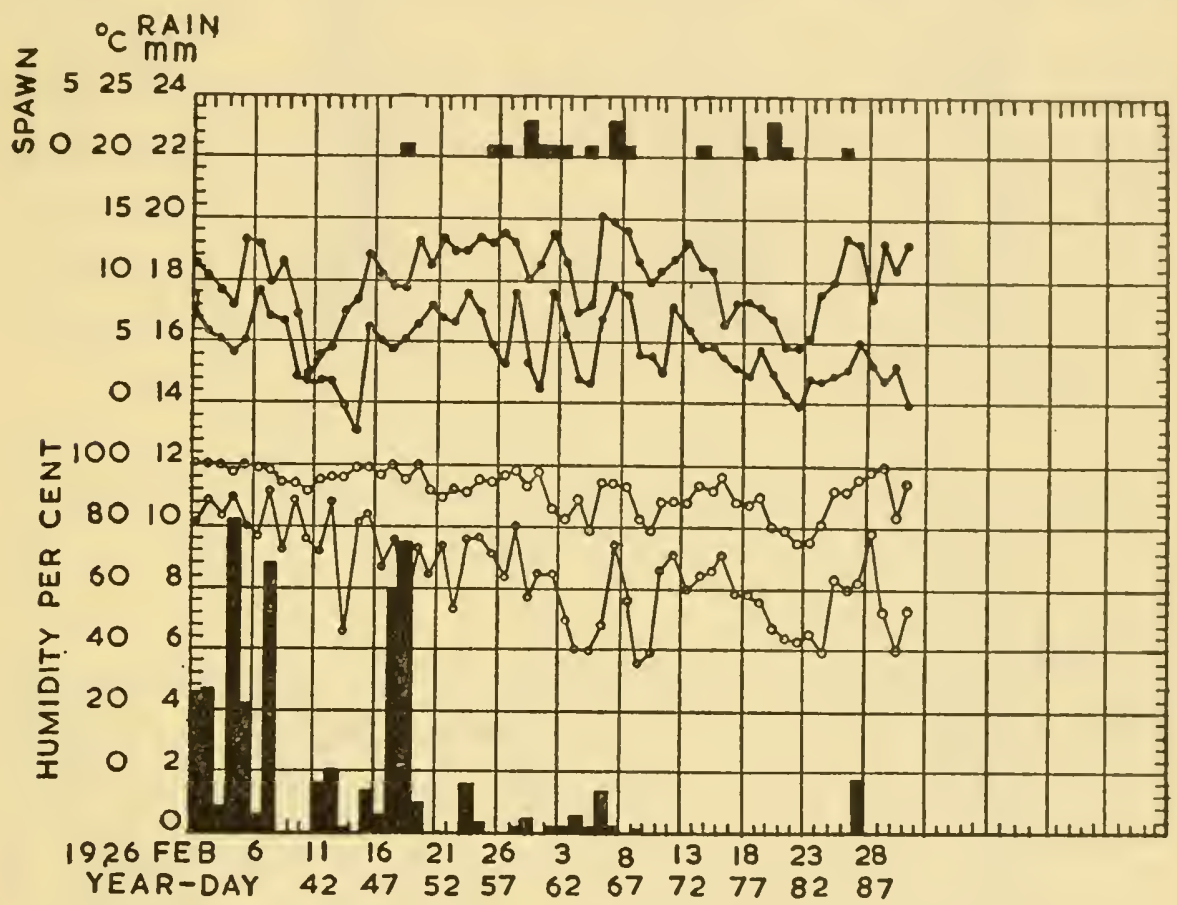

FIG. 29. Chart Showing Maximum and Minimum Temperature, Maximum and Minimum Humidity, and Rainfall for February and up to the Last Date of Spawning in the Area Within so Miles of London, for the Year 1926

Note that this year was early, and that February was wet. The spawning season itself was dry. Note also that much of the spawning took place in a period of falling temperature. In this and other charts, the spawn records are indicated at the top, each unit indicating one report. Rainfall shown is that of the day that is indicated plus that of the previous night.

special pleading that ought not to be admitted without some definite justification. With this in mind, it can easily be seen from the charts (Figs. 29-32) that although sometimes spawning takes place in warm weather, or after a period of rising temperatures, it does not always do so. For example, there was considerable spawning during the cold weather between 7th and I7th March 1928, when the temperatures 


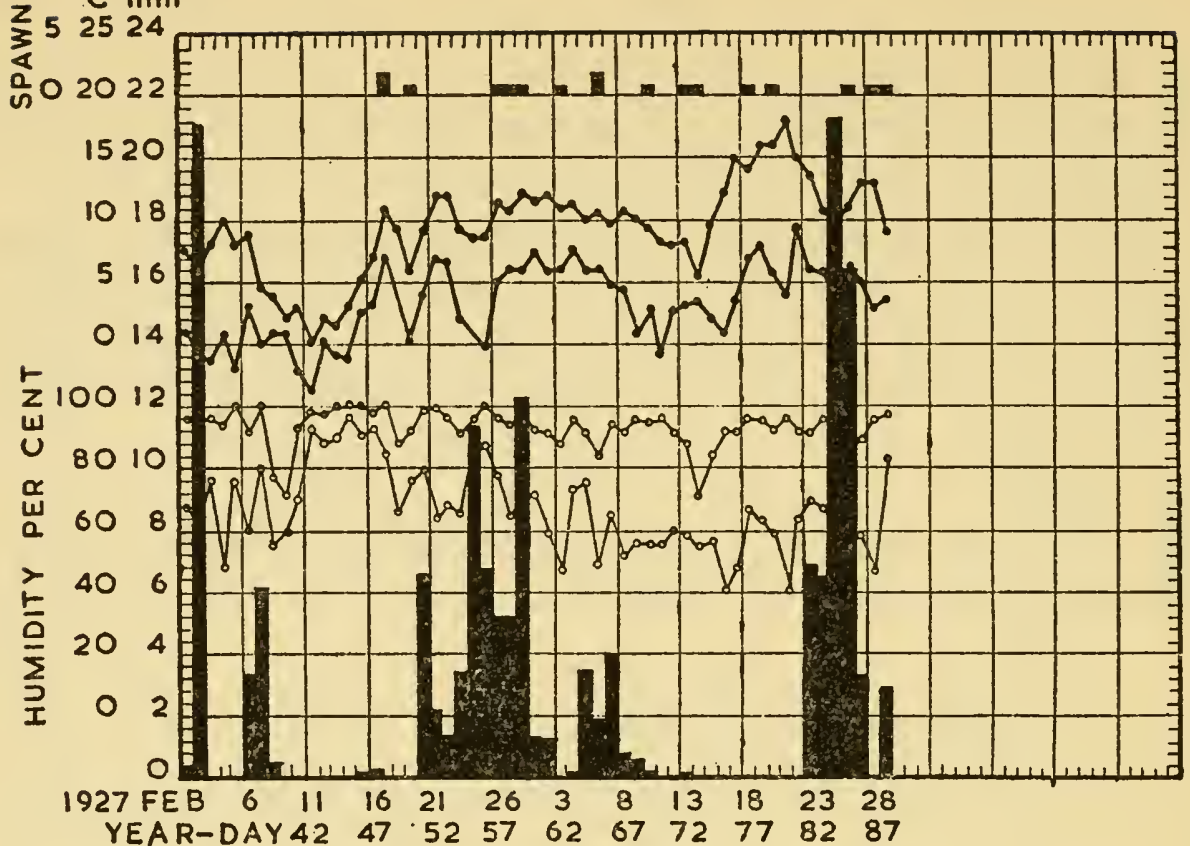

FIG. 30. A Similar Chart for the Year 1927

The weather was wet throughout. Note that there was no concentration of dates during the periods of heavy rainfall.

RAIN

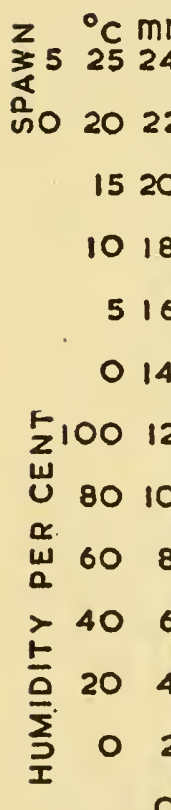

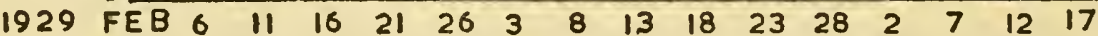
$\begin{array}{lllllllllllllll}\text { YEAR-DAY } & 42 & 47 & 52 & 57 & 62 & 67 & 72 & 77 & 82 & 87 & 92 & 97 & 102 & 107\end{array}$

Fig. 3I. The Chart for 1929

An important chart, showing the effect of a dry February and March. Most of the spawning took place during the drought, some of it in cold weather. When the rain did come, there was no marked accumulation 
were lower than any since the beginning of February. The I 3 th to I7th March 1929 also saw the spawning quite uninterrupted by the cold spell. The middle of the I 927 scason was marked by a slowly falling temperature with no apparent effect on the course of spawning. Turning now to Figs. 33 and 34, we have confirmation from two other areas. Probably because of the presence of meteorological staff in the town or village, observers joined the scheme in two places where there

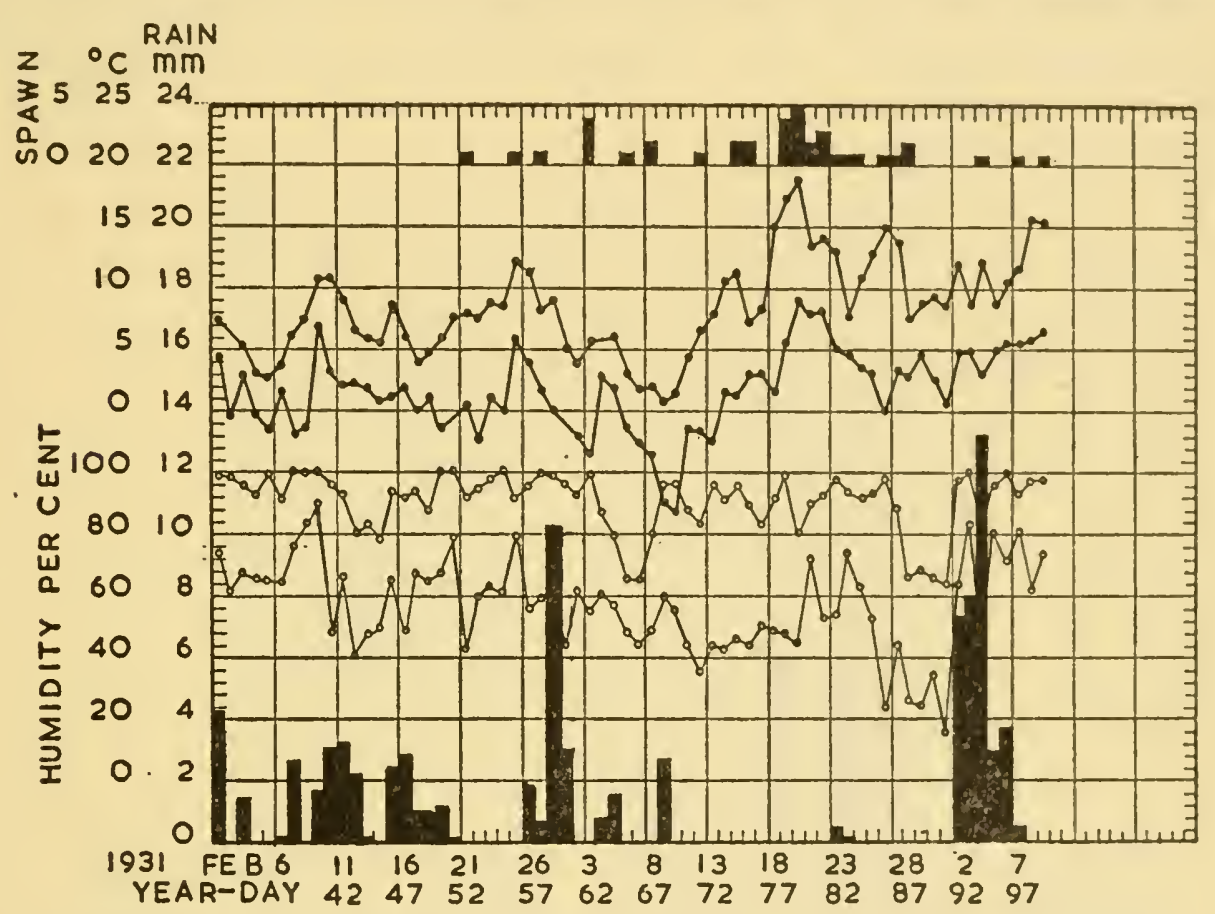

Fig. 32. The Chart for I93 $\mathrm{r}$

A normal year for rainfall, but interesting because of the very cold weather early in March. Some spawning took place in this bitter weather, but there was perhaps an accumulation of reports in the exceptionally warm weather that followed. The temperatures are, of course, shade temperatures. A temperature of $19^{\circ}$ on the 21 st March suggests that some spawn in the sun was near a dangerous temperature.

were Ist Order Observatories, Eskdalemuir, a small village high in the hills of southern Scotland, and Valentia in the south-west of Ireland. Fig. 33 shows the weather of the week before spawning in three years at Eskdalemuir (a), (b) and (c), and one at Valentia, (d), and Fig. 34 shows the weather at every hour of the day and night at Eskdalemuir in two contrasting years. It is impossible, after looking at these diagrams, to believe in any marked connexion between the temperature on the night of spawning and the event itself, for the temperatures 
surely cover anything likely to happen in these islands. It is, of course, probable that if a period of exceptionally severe weather set in so that the ponds froze again, spawning would be prevented, but this is not what is usually meant when it is suggested that the animals are controlled by temperature.

\section{Rainfall}

The London charts show clearly that rainfall at the spawn season is not necessary. In 1929, spawning began in dry weather, and continued

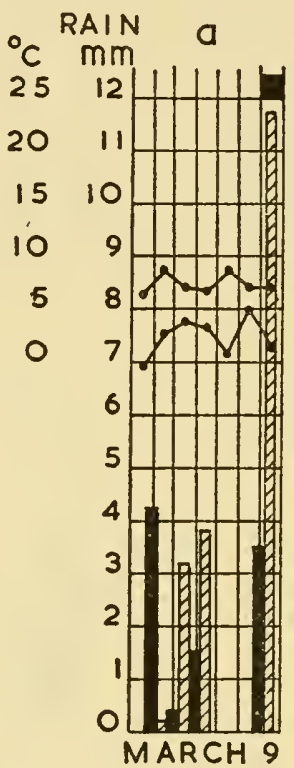

b

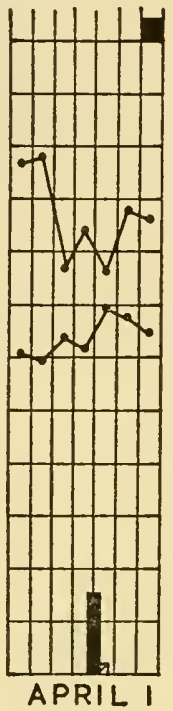

c

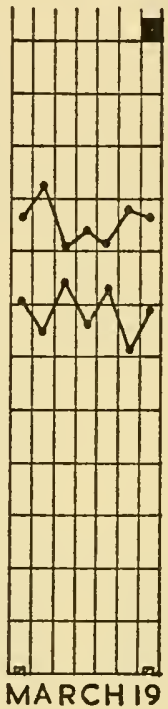

d

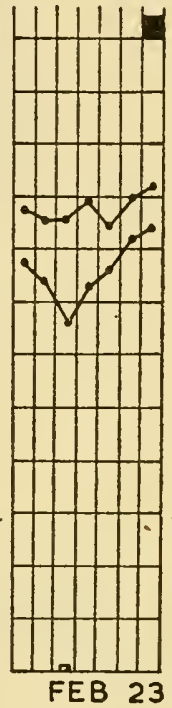

FIg. 33. The Relation of Rainfall and Temperature to Spawning in the Two Places where Observers Lived in the Village or Town in which One of the Five First Order Observatories was situated

At these observatories, hourly records of weather are kept. (a) Eskdalemuir I930, (b) Eskdalemuir I93I, (c) Eskdalemuir I932, (d) Valentia I932. There is not the slightest doubt that the weather of these places was as stated. These charts show the very different weather in which frogs spawn. Note particularly that in Eskdalemuir in I93I there was a frost every night of the previous week, and a falling temperature in this period. In Eskdalemuir in I932 and at Valentia in the same year, there was hardly any rain.

during a period that became a drought, relieved by two small showers late in March. The April rain brought no peak of spawning, for most of the frogs had by then laid their eggs. The wet period at the end of February 1927 did not produce a peak in the spawning. At Eskdalemuir in 1930, there was heavy rain in the later part of the night and the next day after a wet week, but in I93 I no rain fell on the night of 
spawning, and not much in the previous weck. At Valentia, there was no rain at spawning timc, and only $0.1 \mathrm{~mm}$ four days carlicr. Valentia is a very wet place as a rule, so that the frogs were spawning in abnormally dry weather for the district.

\section{Humidity}

Inspection of the charts for humidity is no more illuminating. Since at night humidity is so often over 90 per cent, one cannot expect that

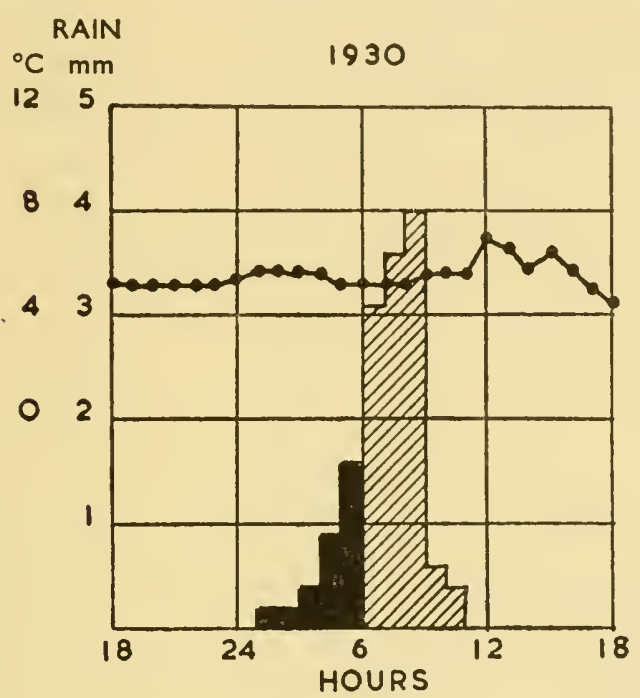

1931

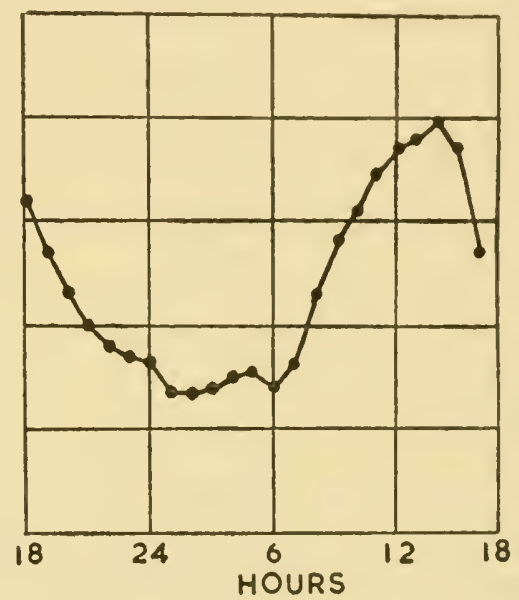

FIG. 34. The Weather at Eskdalemuir in 1930 and I93 I for 24-hour periods

Period extends from 18 hours on the night before spawn was recorded (when it would probably be laid) and for the day itself, when it might perhaps have been laid, up to I 8 hrs. I930 was wet, heavy rain falling from oI hrs to I IOo hrs. The temperature was fairly warm for Eskdalemuir, which is high in the hills in South Scotland. In I93I, there was a contrast. No rain fell, and there was a frost all night from $21.00 \mathrm{hrs}$ to $07.00 \mathrm{hrs}$.

it would be critical for a nocturnal animal, which, when it was active, would always find humidity near to the maximum possible.

After these informal and cursory examinations of the data, the next step is to see whether statistical examination supports the conclusions. For temperature, there were no complications-no significant relations were found, as can be seen in detail in the considerations set out in Chapter ro, Appendix I $h$.

There was a slight non-significant effect suggesting that, with far more results, it might be possible to detect a tendency for more spawning to take place when the maximum temperature was over 
$10^{\circ} \mathrm{C}$, but even if this did turn out to be the case, it is probably nothing more than a minor manifestation of the "poikilothermal effect," and we can dismiss temperature from the picture. With both rainfall and humidity, a remarkable result attended a more detailed analysis.

In rainfall, there was a highly significant association between the rainfall and spawning, but the astonishing thing is that the direction of the effect was the reverse of that expected. Frogs appeared to spawn less in wet weather than random association could account for. This was so surprising that the analysis was carried a stage further. When the rainfall was divided into day rain and night rain, it was found that when the night (during which the spawn was probably laid) had been wet, but the following day (when the observation was made) had been dry, the association was in the expected direction. I suggested that the reason for this remarkable reversal of the effect was that the observers were deterred by the rain from making their observations on a wet day, but postponed them to the next dry day. At the time, I pointed out that if this were the case, there should be an accumulation of reports on the first dry day after a wet spell, but that there was no sign of this. In view of some remarkable features of rainfall relation in the spawning month, to be discussed later, I am now less sure that errors accounted for the discrepancies. There is a good deal of evidence to show that the phenological observers were accurate, and in this case, for example, they observed on both week days and week-ends alike, suggesting that most of them made their observations during their ordinary duties, perhaps on the way to work, It seems unlikely that such people would be deterred by the weather to such an extent. It is possible that we have here a real effect, in which wet weather at the time of spawning delays the event. More information is needed on this point, collected by observers who undertake to observe whatever the weather. There was a similar effect when humidity was examined. No relationship was apparent when maximum humidity, which generally occurs at night, was examined, but minimum humidity, which occurs by day, gave a significant association suggesting that frogs avoided days of high humidity. These are often wet days, so that the humidity effect may not be independent of the rainfall effect.

\section{Joint Functional Regression Diagrams}

Of all the methods used to investigate this problem, these diagrams were probably the most important. They take a long time to construct, 
but, once drawn, are quite easy to understand, for the principle is identical to that of an ordinary contour map. In fact, a map could be called a "joint functional regression diagram, with latitude and longitude as the independent variables, and altitude as the dependent

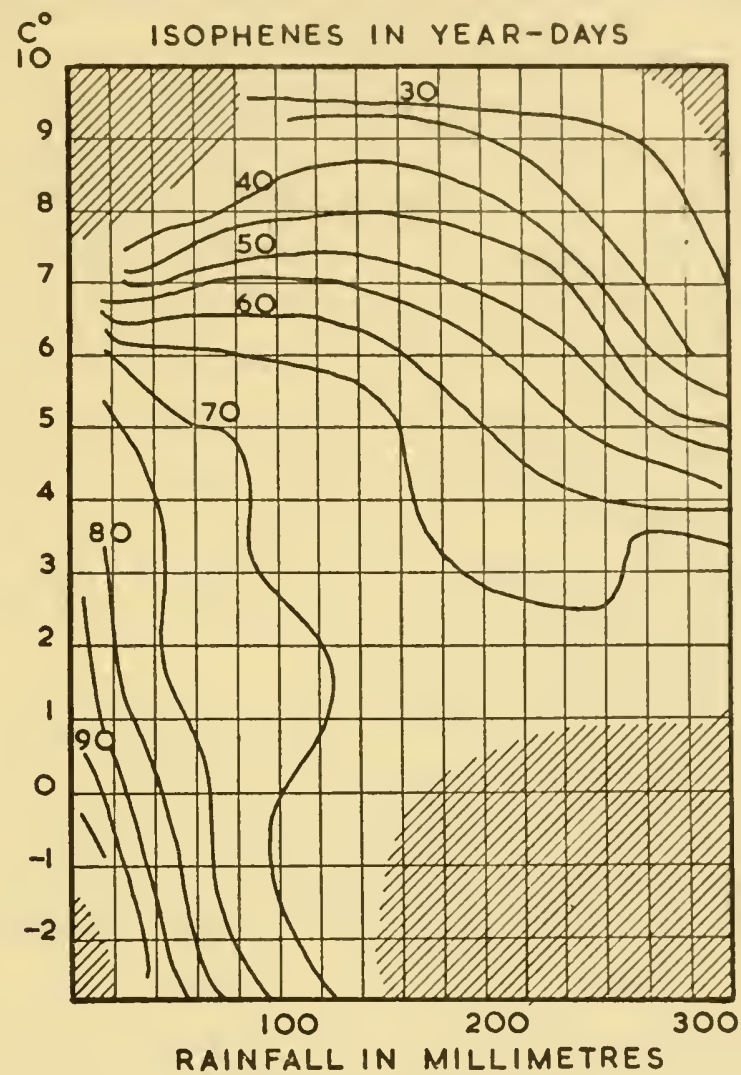

Fig. 35. Joint Functional Regression Diagram, Showing the Relation between Rainfall and Temperature, and Spawning Date, for the Month M2

Note that there is a strong temperature effect above about $5^{\circ} \mathrm{C}$ or $6^{\circ} \mathrm{C}$, but little rainfall effect in this region of the diagram. At lower temperatures, there is a rainfall effect, but very little temperature effect. In all these diagrams, the shaded areas indicate that there are either no records at all with the corresponding variables, or too few for reliable results.

variable." It is shorter to say "map," but there is no word to correspond when the independent variables are different, such as temperature and rainfall, and the dependent variable is spawn date.

The different months were denoted Mo, Mr, M2, because the month in which spawning takes place (Mo) differs so much in different parts of the country that if the calendar months were used for the 
meteorological data, Mo, the spawn month, would be sometimes December or January, often February or March, and sometimes April or even May. Clearly the weather of March cannot influence the frogs that spawn in February. Numbering the months gets over this difficulty, for MI is always the month before that in which spawning takes place, $\mathrm{M}_{2}$ always the month before this.

In Fig. 35 there is an example. The temperature and rainfall of $\mathrm{M}_{2}$ are arranged along the axes, and the mean dates of spawning corresponding to any particular combination of temperature and rainfall are plotted as contour lines. The diagram is therefore a representation of the surface of a solid figure, just as a contour map represents the variations in the altitude in relation to the latitude and longitude. What would be hills on a map are regions of lateness on the diagrams, and the valleys are areas of earliness in spawning. The area has boundaries, just as a country has, where, because there are no records, it is impossible to plot the contours. With this explanation, which applies to all, mutatis mutandis, we can pass to a detailed consideration of the effects that the diagrams have revealed.

M2, Temperature and Rainfall. In the diagram just mentioned, it can be seen that up to a temperature of about $6^{\circ} \mathrm{C}$ this factor is not important. The surface slopes slightly, and, as one goes towards the top of the diagram, one passes almost parallel to the contours. The flat area at about $\mathrm{I}^{\circ}-2^{\circ} \mathrm{C}$ will become more easily understood when the $\mathrm{Mr}$ diagram is described. Above $6^{\circ} \mathrm{C}$, the surface becomes steeper, and it is clear that, at these relatively high temperatures for winter months, two months before spawning, warm weather does accelerate spawning. $6^{\circ} \mathrm{C}\left(42^{\circ} \mathrm{F}\right)$ is the temperature from which the official meteorological calculations of accumulated temperatures are reckoned, although $43^{\circ} \mathrm{F}$ has been suggested as more suitable. These temperatures were chosen because they are approximately those at which plant growth begins to be appreciable. Rainfall has very little influence, for, over most of the diagram, the contours are parallel to the rainfall axis. There is little sign of any joint effect, that is an effect that depends not on a mere sum of both rainfall and temperature effects, but on an increased effect when both act together. The distinctive sign of a joint effect is that the contours are curved, indicating a warped surface. The diagram is thus quite simple. It shows a temperature acceleration, setting in suddenly at about $6^{\circ}-7^{\circ} \mathrm{C}$, very little rainfall effect, and not much joint effect. 
Mi, Temperature and Rainfall. In Fig. 36 a much more complicated state of affairs is presented. The same variables are used, but for the month before spawning, Mr. It is one of the most important. Starting at the bottom of the diagram, at a tempcrature of $-2 \cdot 5^{\circ} \mathrm{C}$, we find, as might be expected, some late dates up to $85^{\circ} \mathrm{C}$. It may come as a surprise to those living in these islands that a mean monthly

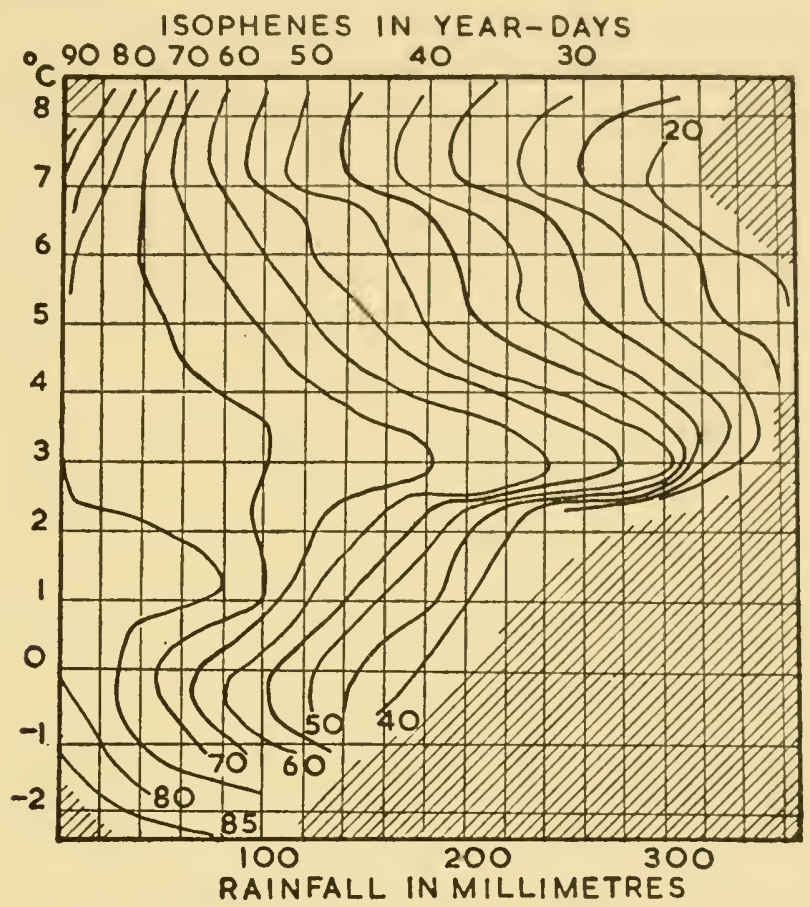

Fig. 36. Joint Functional Regression Diagram, Showing the Relation between Rainfall and Temperature and Spawn Date for the month MI

Note: (I) a trough of earliness at about $0^{\circ} \mathrm{C},(2)$ a ridge of lateness at about $3^{\circ}-4^{\circ} \mathrm{C}$, (3) signs of another ridge of lateness above $7^{\circ} \mathrm{C}$, (4) the latest dates occur at opposite ends of the diagram, when it is either very cold or very hot for the time of the year.

temperature of $-2 \cdot 5^{\circ} \mathrm{C}$ has been recorded, but here is to be found the immense advantage of working with a large scheme such as this. The data for these low temperatures come from very cold winters in parts of the country that have cold climates anyway, and a single observer has no chance of collecting obscrvations such as these, as well as the other extremes that are needed for a complete survey.

Passing now to slightly warmer conditions, we reach the freezing point, $0^{\circ} \mathrm{C}$, and here encounter what was perhaps the most dramatic event in the whole investigation. (It would be quite wrong to suppose 
that the heavy statistical labour of this investigation was all drudgery -from time to time there was the excitement of discovery.) $0^{\circ} \mathrm{C}$ is a minimum date. At both higher and lower temperatures, spawning in the next month is later. When it is realized that we are dealing with an aquatic animal, and an event that takes place in the water, it is impossible to regard the existence of this minimum at $0^{\circ} \mathrm{C}$ as a coincidence; it must be connected with the freezing point of water. Since it is not shown when there has been little rain or snow, it must surely be due to the conditions of alternate freeze and thaw that such a mean temperature must imply, for, of course, a mean temperature of $0^{\circ} \mathrm{C}$ implies that the temperature has been rising and falling through the freezing point, either because of the diurnal range of temperature or because the temperature in different parts of the month varied about this mean. In either case, flooding is to be expected. There is other evidence that flooding accelerates spawning, so that it is probable that this minimum is due to the flooding from melted snow. This, of course, as in the case of other forms of "run-off," brings plant nutrients into the ponds. Barnes and Barnes (1932) suggested that water rich in trihydrol from melting ice was more favourable to the life of algae than dihydrol water from condensed steam.

Passing now still further up the diagram, we find an area between $3^{\circ} \mathrm{C}$ and $4^{\circ} \mathrm{C}$ and $\mathrm{O}$ and $80 \mathrm{~mm}$ of rain where the changes of spawn date induced by these factors are very slight. Since this area comprises some very common conditions, there are parts of the country where the influence of rain and temperature are only observable in exceptional seasons: for examples already discussed, in the London area in 1926 and 1929.

At high rainfalls, still keeping within the temperature range $2^{\circ} \mathrm{C}$ to $4^{\circ} \mathrm{C}$, we find another remarkable feature. A strongly marked ridge of lateness crosses the diagram horizontally. Having already found one of the fixed points of water, the freezing point, on this diagram, it is perhaps possible that here is another: the point of maximum density at $4^{\circ} \mathrm{C}$. This temperature is of great importance in the study of lakes, for there it determines whether the upper layers of water will lie for a whole season without mixing with the lower layers. Twice a year, when the temperature reaches this figure, there is so little resistance to mixing that the whole contents of the lake overturns. This cannot happen in a small pond, for a certain depth is necessary for the phenomenon to occur, but it remains true that this temperature has a unique 
importance. If a pond is at $4^{\circ} \mathrm{C}$, water ruming in at any other temperature will tend to remain at the surface until it is stirred in by the wind. If, on the other hand, the water rumning in is at $4^{\circ} \mathrm{C}$, and the pond is at any other temperature, then the run-off will go to the bottom. It is difficult to decide which of these alternatives is the more likely, for the temperature of a pond is closely corrclated with that of the air at a slightly lower level, and follows it in time. During most of the daylight hours, the pond is colder than the air; at night, the reverse occurs. It will be recalled that a similar ridge exists, in a much less developed form, in the $\mathrm{M} 2$ diagram.

Near the top of the diagram, at about the $7^{\circ} \mathrm{C}$ level, another change occurs. Above these temperatures, the spawn date gets later the warmer the weather, and at the low rainfall area, the late isophenes appear again. In the extreme corner, where the temperature is very high for the time of the year and there is little or no rain, the 90-day isophene makes a limited reappearance, so that the latest dates are to be found at opposite margins of the whole diagram.

Mo, Temperature and Rainfall. It is obvious that the weather near the end of Mo cannot affect the actions of frogs spawning at the beginning, and, for that reason, the use of a mean value for this month must introduce errors. It is, however, a property of the weather that it runs in spells, so that the Meteorological Office can head its monthly reports with a condensed summary in a short phrase, such as "Warm in the west, colder and windy in the rest of the country." The mean values used in this work are therefore not so bad a measure as would seem at first sight. Moreover, spawn dates near the end of the month can clearly be quite reasonably correlated with the mean values. A computation of accumulated values, as was done in 1935, would have been very laborious with the 2,734 results of this chapter, and, moreover, could not have been done for many of the meteorological stations, because many of the details are not published.

The Mo diagram resembles that for $\mathrm{MI}$ in many respects, and contains only one quite new feature. This is a well-marked ridge of lateness running vertically through the diagram at about the fortymillimetre level of rain. There are so many records in this region, I, 478 of them, that there is little doubt about the reality of the effect. It must be concluded that very light rain in the spawning month results in a later date than if no rain fell at all. It should now be recalled that some peculiar circumstances attended rain in the daytime at 
spawning time. I cannot so easily credit that observers' errors are at work in the phenomenon now under consideration. James (1944) found that the calling of Hyla nigropes, which breeds in Costa Rica in the dry season, occurred regularly at sundown, except when the afternoon had been raining. Evening rain had no effect of this kind.

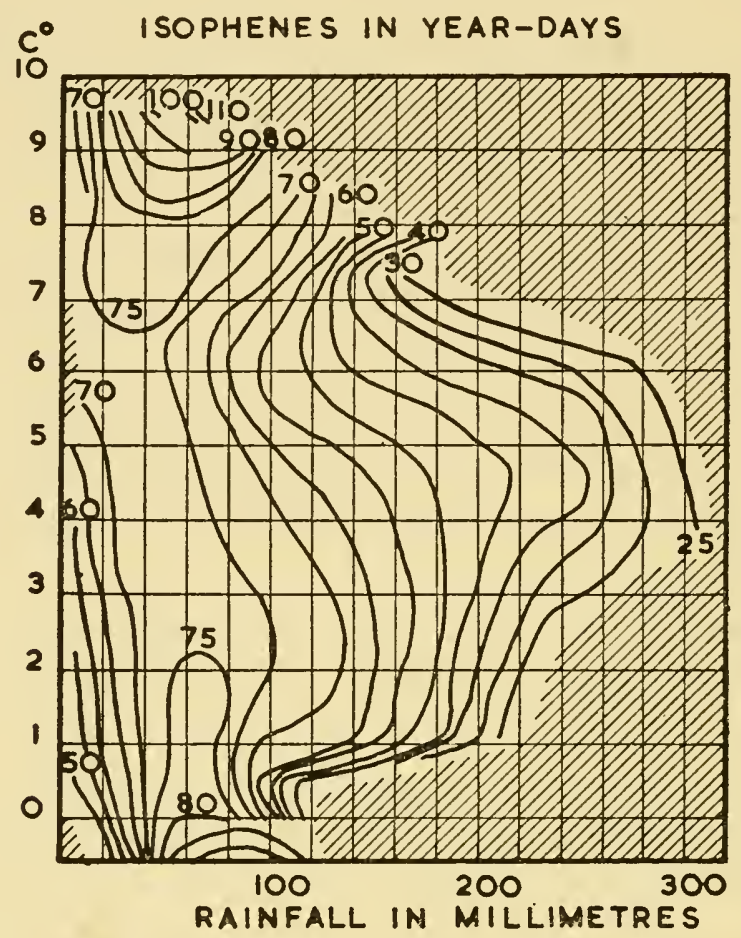

Fig. 37. Joint Functional Regression Diagram, Showing the Relation between Rainfall and Temperature, and Spawn Date for the Month Mo

The diagram at rainfalls higher than about $80 \mathrm{~mm}$ resembles that for $\mathrm{Mr}$, but is distinguished by a well-marked ridge of lateness almost vertically through the diagram at about this value for rainfall. There is something that determines that frogs should be later when Mo is fairly wet than when its is drier. At high rainfalls the usual relation is observed.

This could, of course, be a coincidence, and nothing to do with the phenomenon we are discussing. Forty millimetres for a whole month is light rainfall. That it should fall so often at the exact time when the observers were about to inspect their ponds is rather difficult to believe. I feel fairly certain that this is a real event, and perhaps we should seek for a possible common cause for both phenomena. When we come to consider light it may be possible to suggest a rational explanation. 
The parts of the diagram to the right of the ridge resemble those of the Mi diagram. There is some sign of an carly valley at about $0.5^{\circ} \mathrm{C}$, but these temperatures rarely occur in $\mathrm{Mo}$, and, if this feature stood alone, without the corresponding feature in the MI diagram, it would not be statistically significant. There is again a ridge of lateness at about $4^{\circ}-5^{\circ} \mathrm{C}$, but it is not so well marked. At high temperatures, there is again evidence that high temperatures delay spawning. In spite of popular impressions to the contrary, I find nothing surprising in this. I have experienced scasons in which exceptionally warm weather occurred with no sign of the frogs, until a date that was unusually late, for example in 1949, when the weather at the usual spawning time resembled that of the summer, but there were no frogs in my ponds.

\section{Light}

It will be recalled that when the map was being discussed, the latest areas, except the Crossfell district, were industrial. Moreover, as will be shown later, there is a tendency for the North to be later than the South, although the West is earlier. Now in winter, the temperature of the North is not much different from that of the South; it is in summer that the temperatures are different. Geologically, the North resembles the West rather than the East. It was therefore rather surprising to find the North so much later. The algal hypothesis has all along suggested that there should be an effect of light. In winter, the North is darker than the South, and there is less light still in industrial districts. It is unfortunately impossible to use length of day as a factor in this investigation, because there is an invariable astronomically determined relation between day length, latitude and date. Fix any two of these and the third is fixed. Since we use spawn date as one variable, day length and latitude are merely alternative expressions for the same fact. We can choose to use one but not both. However, if we use the amount of bright sunshine, expressed as a percentage of that possible at the particular place, then we have a factor that is not rigidly connected with geographical position and date, but varies with the weather and with local peculiaritics. It is therefore a factor we can use as easily as if it were temperature.

Since it was already apparent that rainfall was acting in the form of run-off, it was possible that sunshine would act in two opposing ways. It is known that sunshine increases evaporation (Penman, I948), so 
that it must diminish run-off. If so, it should delay spawning. But if there is not much rain in any period, there may be no run-off to diminish, for this ceases at low rainfalls. It was therefore possible that when the rain was low, a direct action of sunshine would be revealed

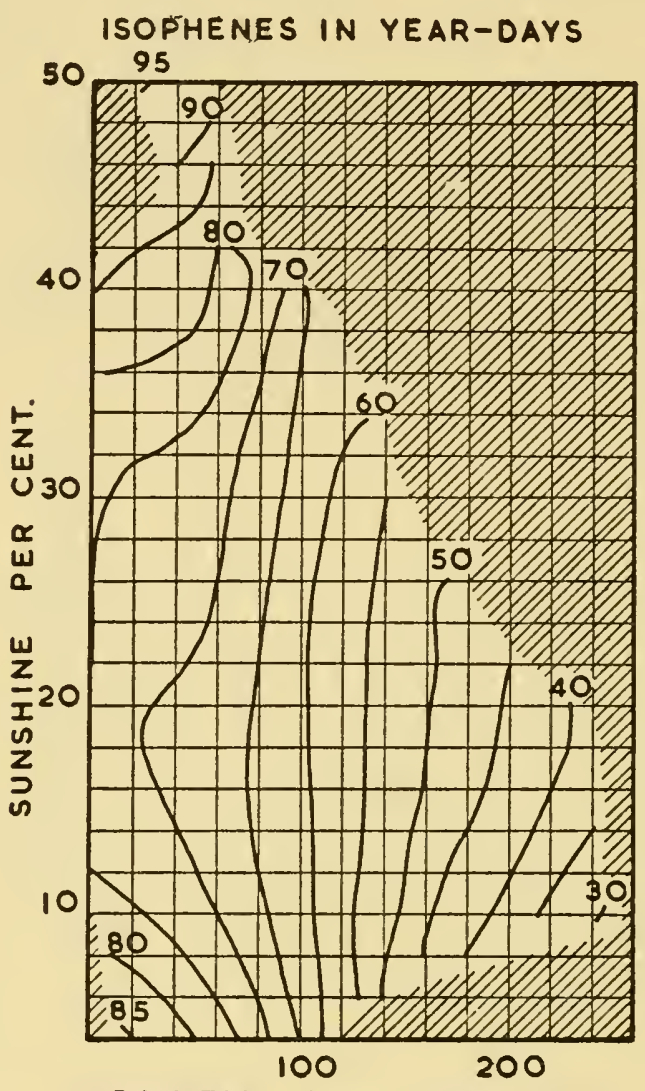

RAINFALL IN MILLIMETRES

FIG. 38. Joint Functional Regression Diagram, Showing the Relation between Sunshine and Rainfall, and Spawn Date, for the Month MI

The most important part is between about $80 \mathrm{~mm}$ of rainfall and $\mathrm{I} 8$ per cent of sunshine, where alone sunshine accelerates spawning. Under all other conditions, sunshine retards spawning. Note particularly the very late dates when it has been both sunny and dry.

as an accelerating influence. Which of these effects would predominate could not be forecast, and the final graphs provided another of the dramatic episodes of the investigation, for both effects appeared at the correct places on the same diagrams.

Mr, Sunshine And Rainfall. At low rainfalls, so low that there would be little or no run-off, the effect of this factor disappears. In 
this region of the diagram (Fig. 38), and nowhere else, sunshine accelerates spawning, In the other parts of the diagram, where there would be some run-off, sunshine delays spawning. These effects, I must point out, occur in this month, when the frogs are hibernating, mostly in the dark.

Mi, Sunshine and Temperature. Much the same occurs when sunshine and temperature are used as joint factors (Fig. 39). At low

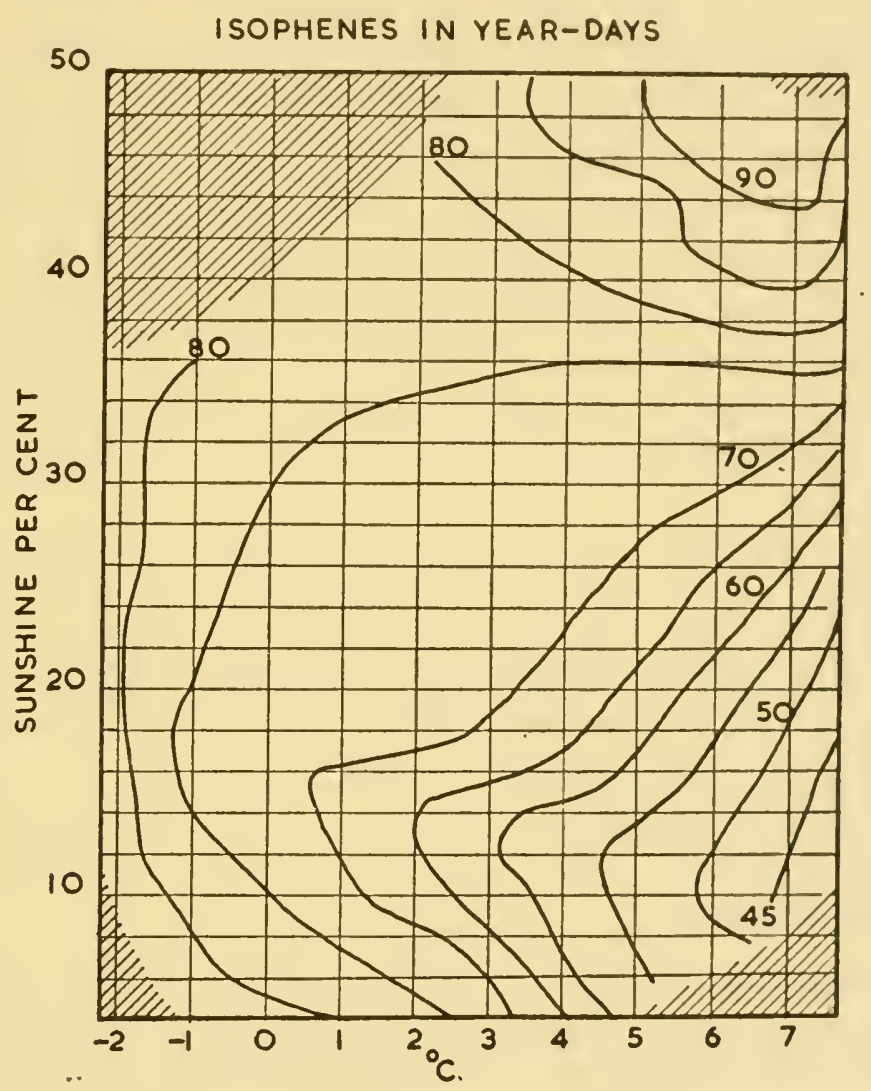

Fig. 39. Joint Functional Regression Diagram, Showing the Relation between Sunshine and Temperature and Spawn Date, for the Month MI

Below about 14 per cent of sunshine, spawning is earlier when there is more sunshine, but above these low amounts, sunshine always retards spawning. Note the late dates when it is hot and sunny, in the top right hand part of the diagram.

temperatures, the evaporating property of sunshine is less prominent than at high temperatures. At low temperatures, sunshine accelerates spawning. At all other temperatures, it retards. Taken in conjunction with the other evidence, this seems convincing support for the 
existence of a light effect. It should be added that the impossibility of using day length as a factor does not imply that it is not acting. On the contrary, it is almost certainly adding its effects to those that can be studied, and it is only the properties of the solar system that have technically interfered with its direct investigation.

\section{Altitude}

In places that are liable to have orographical rain, that is rain caused by hills lying in the path of wet winds, it was found in the r 935 paper that there was a tendency for spawning to be earliest at about 800 feet. At altitudes lower and higher than this, dates were later. Faris (1944) confirmed this by observations on a hill in Ireland, and found in a series of ponds that there was an early point at 600 feet. I suggested that this was due to a point of balance between the increase of rain with altitude, and the decrease in temperature. Dr. J. Glasspoole pointed out to me that these are the altitudes with minimum fog, and in view of the light effect, this suggestion should not be overlooked. Perhaps both are acting.

In other parts of the country, not only are these effects much smaller or non-existent, but there are not many observers living at such altitudes. The result of this is that in the larger investigation of 1956-8 no significant correlations with altitude were found-the effects were swamped by the numerous observations from areas where nothing of the kind could be expected.

\section{Regression Methods}

These diagrams, although very illuminating, are theoretically liable to a disadvantage, for each contains the influences of the other factors. This effect is not so great as it would be if all the correlations were large, as is explained in Chapter Io, but it was nevertheless felt desirable to use another method to prove the independence of the various factors. It would be possible to remove the effect of the other factors from each diagram, but on this large scale, the process is excessively laborious; it would probably have taken years.

The method adopted is standard statistical practice: multiple linear regression analysis. The final result is that each factor appears free from the effects of every other factor as a coefficient in an equation.

If the variables are denoted as follows, the equation can be set out concisely. 
Let $\mathrm{Y}=$ Spawn date in year days, $\mathrm{AP}=$ Altitude of Phenological station in feet, $A M=$ Altitude of Meteorological station in fect, $\mathrm{RMo}=$ Rainfall in Mo in $\mathrm{mm}$, TMo $=$ Temperature in $\mathrm{Mo}$ in ${ }^{\circ} \mathrm{C}$, $\mathrm{RMI}=$ Rainfall in $\mathrm{Mr}$, in $\mathrm{mm}$, TMr $=$ Temperature in $\mathrm{Mr}$, in ${ }^{\circ} \mathrm{C}$, $\mathrm{SMr}=$ Bright sunshine in $\mathrm{MI}_{\mathrm{I}}$, in $\%, \mathrm{RM}_{2}=$ Rainfall in $\mathrm{M}_{2}$, in

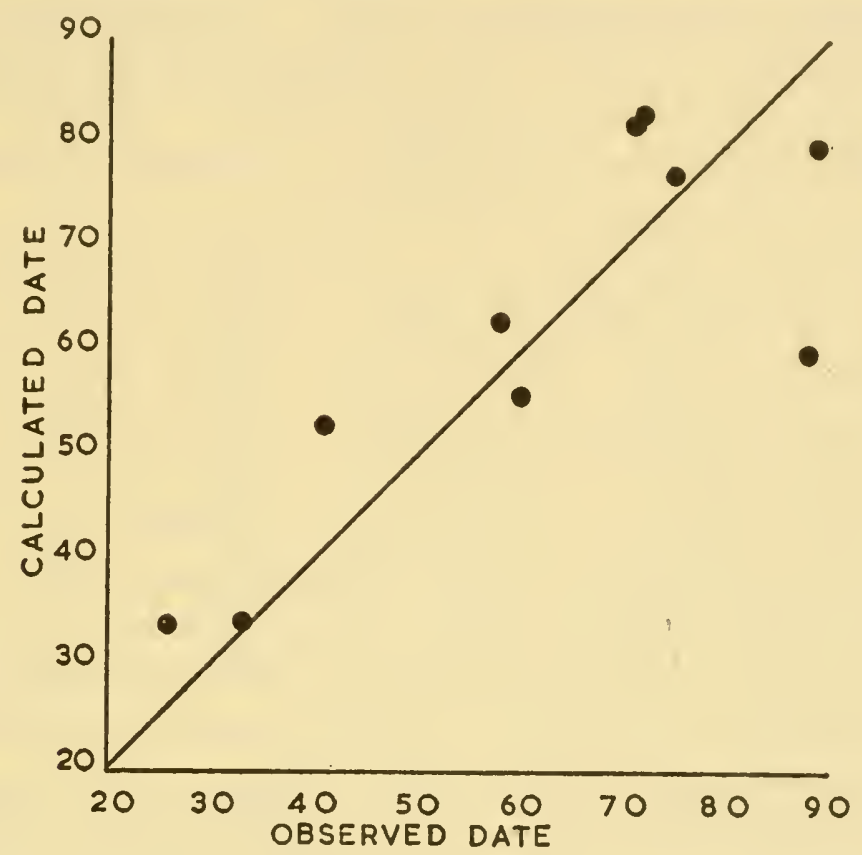

Fig. 40. An Informal Test of the Regression Equation

Ten records were taken at random, and the corresponding variables substituted in the equation to give a calculated date. This has been plotted against the actual date. The agreement is good, only one point being far wrong.

$\mathrm{mm}, \mathrm{TM} 2=$ Temperature in $\mathrm{M} 2$, in ${ }^{\circ} \mathrm{C}, \mathrm{LT}={ }^{\circ}$ Latitude, $\mathrm{LG}=$ ${ }^{\circ}$ Longitude. Then-

$$
\begin{aligned}
\mathrm{Y}=57.5 & +(0.0035) \mathrm{AP}-(0.003 \mathrm{I}) \mathrm{AM}+(0.02) \mathrm{RMo}+(0.9 \mathrm{I}) \mathrm{TMo} \\
& -(0.0707) \mathrm{RMI}+(0.17) \mathrm{TMI}+(0.030) \mathrm{SMI}+(0.009) \mathrm{RM} 2 \\
& +(3.10) \mathrm{LT}-(3.4) \mathrm{LG}
\end{aligned}
$$

Fig. 40 is an informal illustration of the way in which it fits the facts. Ten dates were chosen at random and the values substituted in the equation, so as to obtain a date by calculation. The actual dates were then plotted against the calculated dates. It can be seen that only one date is much out of line. In the other cases, if the pond had been visited on the calculated date frogs might have been there, just departed or 


\section{I44 ECOLOGY AND LIFE HISTORY OF THE COMMON FROG}

just about to arrive. Formally, the multiple correlation coefficient is 0.74. The square of this number is a measure of the proportion of the total variance accounted for by the equation, so that $S \mathrm{I}$ per cent of the causes of variation of all kinds have been accounted for. This, however, is an understatement. We know that many of the relations are not linear, and act jointly as well. To construct an equation that takes this into account is impracticable. If it had been possible, there is no doubt that the fit of such an extremely complicated function would have been better. Now, in many biochemical experiments in a laboratory, the amount of variation not accounted for reaches at least 25 per cent. We really cannot expect that frog-spawn records obtained in the field would be better. Taking all these points into consideration, we must, I think, conclude that the factors controlling the date of spawning have been identified and measured as far as can be reasonably expected. This is not to say that the equation is the last word on the subject. On the contrary, the latitude and longitude factors almost certainly are merely "dustbins" into which have been thrown any effects correlated with latitude and longitude that have not otherwise been considered. For example, the longitude effect is, I think, probably of geological origin, but I have no numerical values for this, and cannot think of any way of getting any. I have already said that the latitude effect probably includes length of day, which cannot be used, and I have not considered even bright sunshine in more than one month, Mr. Finally, if the algal hypothesis is true, the whole equation could be replaced by one factor, an event in the life of a plant or plants.

In my view, the principal value of the equation is that it shows the independence of the various factors. It is, for example, not now possible to argue that the effect of rain is really due to the temperatures associated with rain, for all the necessary allowances have been made. Moreover, this has been done not by bringing in any information from outside the data, but solely from within, as if we knew nothing except these figures.

The coefficients in the equation give no easy idea of the importance of the various factors, or of the closeness of the correlation between any of them, considered alone, and the spawn date. The usual way of testing for such correlations is to compute partial correlation coefficients, as was done in 1935, but, with data so voluminous as these, the operation is excessively laborious, and an alternative was used. Table 7 
shows the beta coefficients, calculated as percentages. They give a good idea of the relative importance of the factors. It can be scen that the most important are-

Retarding influences: raised tempcrature in Mo, increase in latitude, increased sunshine in Mr.

Accelerating influences: increase in longitude, raised temperature in $\mathrm{M} 2$, increased rainfall in $\mathrm{Mr}$.

TABLE 7

$\beta$ COEFFICIENTS

\begin{tabular}{l|c|c}
\hline Variable & $\beta$ & $\beta \%$ \\
\hline AP & +0.042 & $+\mathrm{I} .9$ \\
RMI & -0.224 & -10.3 \\
TMI & +0.006 & +0.3 \\
LT & +0.321 & +14.7 \\
LG & -0.455 & -20.7 \\
AM & -0.046 & -2.1 \\
TMo & +0.535 & +24.4 \\
RMo & +0.069 & +3.2 \\
RM2 & +0.038 & +1.7 \\
TM2 & -0.348 & -16.0 \\
SMI & +0.102 & +4.7 \\
\hline
\end{tabular}

This list alone is enough to show how impossible it would be to unravel such a complex subject without a large quantity of data and a full use of statistics. No human mind could hope to see what was happening merely by examining the records, much less by making observations in one district.

\section{Discussion}

It now seems desirable to gather together a considerable number of the complicated facts that have been discovered, for if they are considered as a whole, it will be seen that they form a definite pattern, not detectable from any of them alone.

The properties of water appear everywhere. There is the effect of rainfall, viewed simply as an accelerating factor. Apart from this, a critical point at $0^{\circ} \mathrm{C}$ can surcly not be related to anything else than the freezing point of water. The cvaporation of water from the soil is of economic importance, and Penman (1948) showed that the main factors in this are: temperature, wind velocity, humidity and bright sunshine. Run-off is obviously related to the same factors, with the addition of the rain itself. It is well known that run-off ccascs altogether 


\begin{tabular}{|c|c|c|}
\hline & 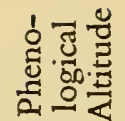 & 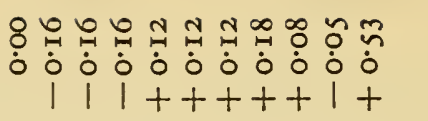 \\
\hline 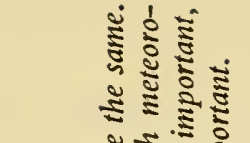 & 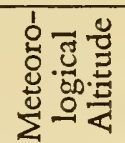 & 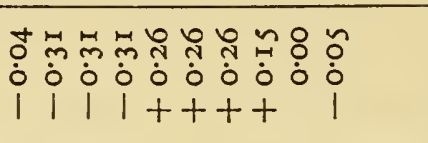 \\
\hline 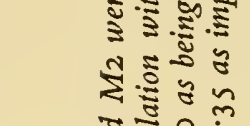 & 占点费 & 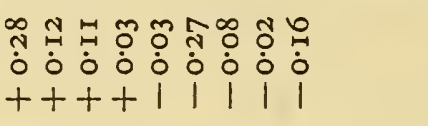 \\
\hline 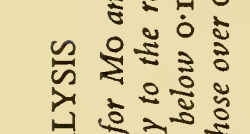 & 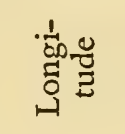 & 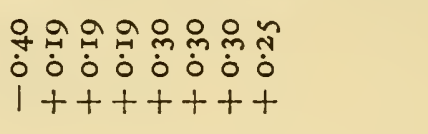 \\
\hline 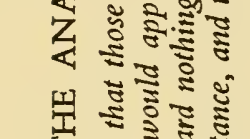 & 岇苛 & 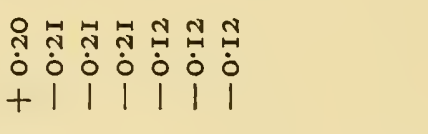 \\
\hline 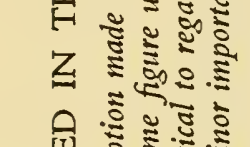 & . & 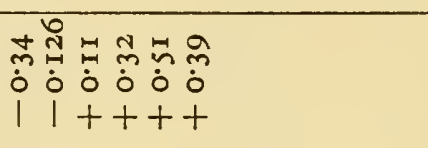 \\
\hline 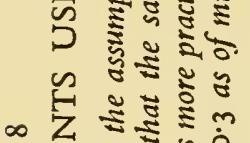 & 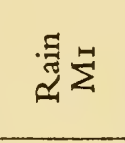 & 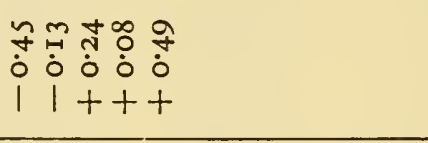 \\
\hline 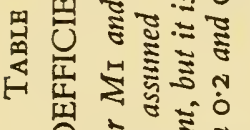 & 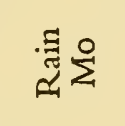 & 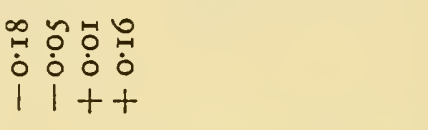 \\
\hline 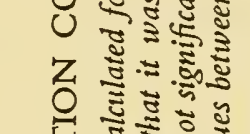 & ت્ّ & 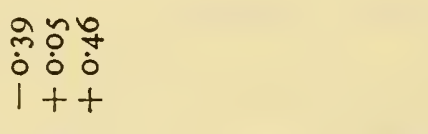 \\
\hline 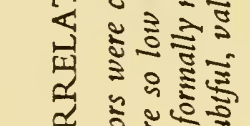 & 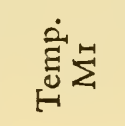 & 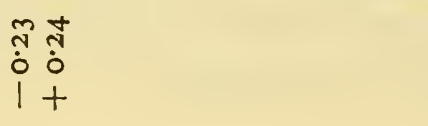 \\
\hline 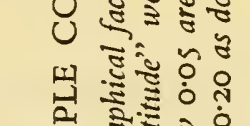 & 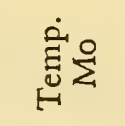 & $\begin{array}{l}\hat{\vdots} \\
+\end{array}$ \\
\hline 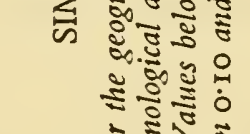 & 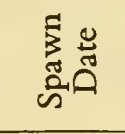 & \\
\hline 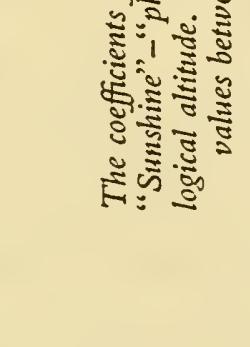 & & 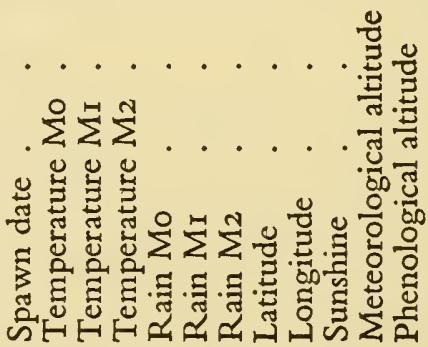 \\
\hline
\end{tabular}


at low rainfalls. For example, in the Thames basin, there is no run-off when the rainfall over a period is less than 52 per cent of normal. In many places on the diagrams it can be seen that the effects of other factors, such as temperature, are only shown when the rainfall is high. The exception is in the sunshine diagrams, and this has been explained as being due to the antagonistic effects of sunshine, which causes evaporation and so reduces run-off, but has another effect as well in the opposite direction. When the temperature is so high that evaporation can be expected to be abnormally high for the season, spawning is delayed. The mineral composition of the pond water is also important. Frogs prefer ponds with high potassium, and those which, from a high level of phosphate in January, fall to a low one at spawning time. This pattern is well known to be characteristic of ponds that have a rapid growth of algae.

To suppose that rainfall is acting directly on the frogs is surcly most improbable. Many of them are already hibernating under water at the time when these factors are operating, and could not be affected by evaporation. Moreover, they may leave these aquatic hibernating places for other ponds in which they spawn, so that they could not be under the influence of potassium or phosphate in the ponds, for they are not even there. The same applics to light. Some frogs may be in the light when they are hibernating, but most are not. Yet sunshine in a month when they are still hibernating affects the spawn date. Now, it cannot be argued that some frogs are affected by these factors, and that some are not, for the spawning season in one pond is so short that all the frogs in it must have been under the influence of the same factors. If they were not, there should be two widely different groups arriving at quite different dates, separated perhaps by months. This does not happen. If, on the other hand, ponds differed so that some contained frogs in the winter, but some did not, and that this affected the date of spawning in them, then ponds should fall into two groups: carly and late. The charts, Figs. 29-32, show no sign of this but Fig. 4I is more convincing. In this diagram are plotted all the available results from South-East England, as departures from the mean date for the year in that district, so as to eliminate the variation from year to year. If there were two groups of ponds, this graph should have shown two peaks. It did not, so that we must suppose that spawning in a district is a continuous process. The shape of this diagram has some statistical interest, and is discussed in greater detail in Chapter 10. 
I think that the evidence is conclusive. The frogs are influenced by something that happens to their ponds in the winter, even if they are not in those ponds. Now, what could be happening that is consistent with the facts?

It has been known for many years that the spring growth of algae is accelerated by the presence of plant nutrients brought in to the ponds by the run-off. Rain does not usually dilute a pond; on the contrary, it is a fertilizing agent (See the rises in phosphate after rainfall in Fig. 24). Among these nutrients are, of course, potassium and phosphates.

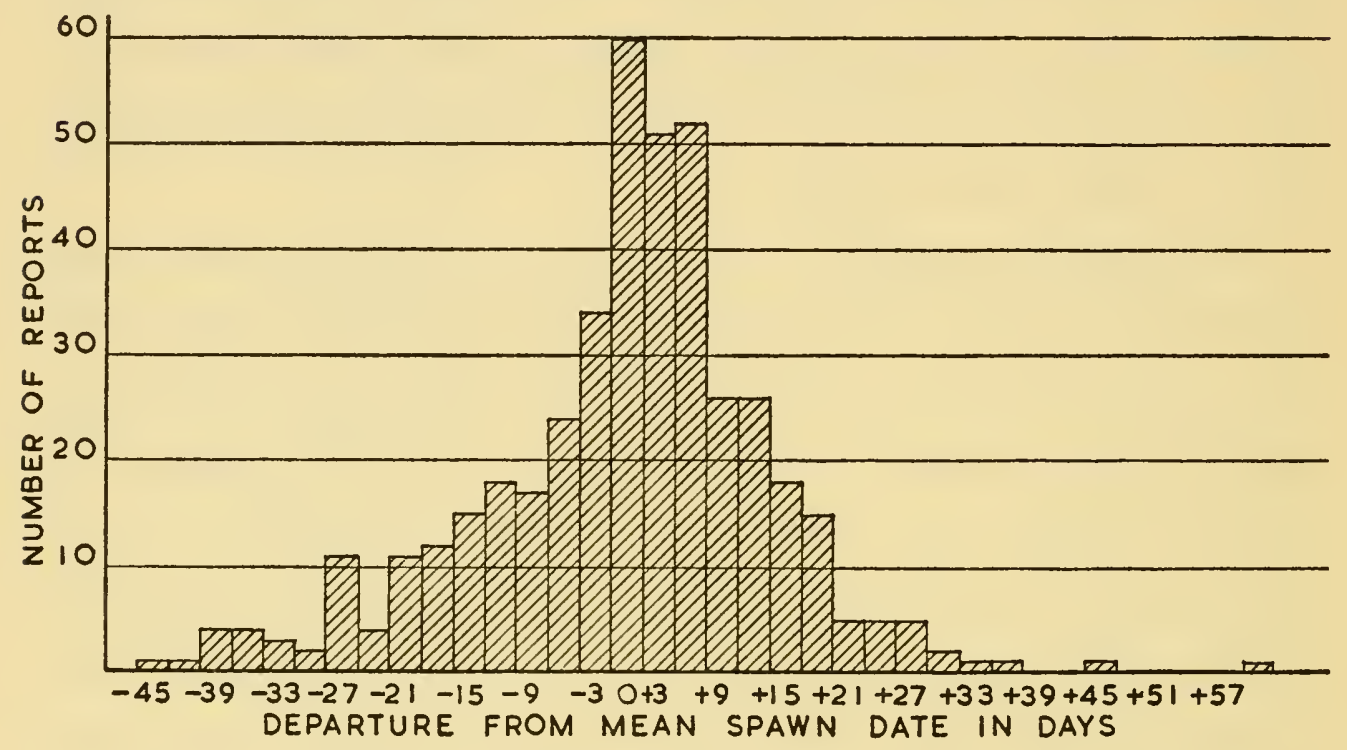

FIG. 4I. Histogram Showing the Distribution of Spawn Records They are plotted as departures from the mean date in each year, for 24 years in a fairly uniform area, SE England. This curve is not of the normal form being sharply peaked and negatively skewed.

Phosphates tend to be the limiting factor, and in fact water undertakers use the level of phosphate as an indication that the peak of algal production has been reached, so that their troubles with consumers over tastes and smells are nearly over. Light is obviously an important factor, and, indeed, with certain underground waters, every effort must be made to avoid exposing the water to light before passing it into the mains, for, otherwise, algal growth is certain to be troublesome. In spite of modern methods of control, it is still necessary sometimes to take a reservoir temporarily out of service until the algal peak has passed. There have been cases of reservoirs proving so troublesome that, in spite of the cost, they have been abandoned. If indeed it is 
smell that guides a frog to its pond, then it must surely be the smell of the algae, for it is these that are very well known to be the cause of the smell of normal water.

It will almost certainly be difficult to unravel this complicated subject by more field observations. The obvious thing to do is to try to find some direct relation between the algae and the frogs. Work on this is proceeding, but it may be of interest to see why it is difficult. In a small pond there may be as many as two hundred species of algae. Since $R$. temporaria spawns in a considerable varicty of habitats, it is unlikely that the frogs are connected with only one species. Probably, on the analogy of most herbivorous animals, they are confined to a large but not unlimited number of algal species. We shall have to identify a group, any one of which may serve for the frogs. Algae have very complicated life histories, and the water undertakings sometimes find that tastes and smells are at their worst when the algae are dying away. But the critical period could equally well be a maximum period of abundance, or the beginning of a cycle. Or it might be some phase in the life of the plants, such as the liberation of swarmers. Worse still, it could be that the frogs avoid certain species of algae. The fishing industry now uses the presence of certain species of planktonic algae that occur in patches of sea to show them where not to cast their nets, for the fishes are not to be found in those areas. But perhaps this is unlikely, in view of the migration observations, which seemed to show definite attractions. Methods of sampling the sessile species of algae, the most likely group, are difficult, particularly from surfaces of mud. I know of none that can be used quantitatively on floating weed mats, often used by frogs, and often encrusted with algae. Finally, our knowledge of the events in small ponds is far behind that available for lakes. Ponds are very complicated places, liable to violent changes in conditions.

The direct experimental study of the weather factors is out of the question. We can control the temperature of small laboratory vessels quite easily, and light is not a difficult factor, if we are working under sterile conditions and can be sure that we are not dealing with indirect effects. Humidity can be controlled by more claborate instrumentation. There is not sufficient knowledge available to imitate under controlled conditions the immense complexity of rain falling on soil and running through it into water. Even if we did know how to do this, we should have to set up a large number of planned experiments 
and keep them going for months, and repeat them for years before we could hope to investigate the factors with the same detail as was done in the work described in this chapter by direct analysis of the field data.

It is, of course, quite illogical to expect a biological situation to be simple, for almost all that have been thoroughly investigated have been found to be very complicated. This one looks as if it is not an exception to this rule, and anyone contemplating setting up simple experiments of the "frog-in-bottle, one-factor-at-a-time" type should reflect on the following comments by Fisher (1935)-

"We have usually no knowledge that any one factor will exert its effects independently of all others that can be varied, or that its effects are particularly simply related to variations in these other factors. On the contrary, if single factors are chosen for investigation, it is not because we anticipate that the laws of nature can be expressed with any particular simplicity in terms of these variables, but because they are variables which can be controlled or measured with comparative ease. If the investigator, in these circumstances, confines his attention to any single factor, we may infer either that he is the unfortunate victim of a doctrinaire theory as to how experimentation should proceed, or that the time, material, or equipment at his disposal are too limited to allow him to give attention to more than one narrow aspect of his problem."

It is, however, not impossible that, having outlined the main factors operating in the field, and having a hypothesis that seems to fit the facts, laboratory experiments in conformity with the field observations could be useful. It should be easy now to detect irrelevancies, for if the laboratory experiments do not fit the known facts, however interesting they may be in themselves, they would not be relevant.

It would be quite wrong to conclude this chapter leaving the reader with the impression that the algal hypothesis has been universally accepted. In fact, it is probably true to say that the general attitude has been one of polite incredulity. In reflecting on possible reasons for this, I came across the following remarks by Fisher (1956, p. 40). He was discussing the resistance shown by the normal mind to accepting a story intrinsically too improbable, and listed four common reactions-

"(a) The whole thing is a fabrication.

(b) There is no sufficient reason to think that the facts were observed and put on record accurately. 
(c) There has been exaggeration, and the omission of circumstances that would help to explain what is claimed.

(d) Some occult cause, beyond our present understanding must be invoked."

If Fisher is right, then the incredulity may be due to a belief that the story is intrinsically too improbable. This never occurred to me. Frogs live their aquatic life invariably among algae, which dominate the life of a pond. It has been said that if all the higher plants in a pond were to be removed and replaced by glass models of the same shape and size, the animal life in the pond would go on just the same. Remove the algac, and life would be vastly different. Knowing the number of parallels between the behaviour of frogs and the bchaviour of algae, and that no two essential oils have the same chemical composition or the same smell, I have always thought the hypothesis suffered from the difficulty of proof, rather than from any improbability. But there is no need to despair. After all, it was only in late I957 that we had experimental proof that satellites were kept in their orbits by gravitation. Up till then the whole thing had been a hypothesis, based on a number of parallels!

\section{Other Species}

I have not made any allusion to work on other species. So far as I know, there are no statistically satisfactory analyses, but only a large number of opinions. Even if figures are quoted, the authors commonly omit to record the negative cases as well as the positives. Unless both are recorded in such a way that either the authors themselves or their readers can fill up all the four spaces in a $2 \times 2$ contingency table of the type used freely in this book or ise some other statistical test, then we cannot judge whether the statements are sense or nonsense. The author may be right, but all we can do is to accept or reject what he thinks, and this is not science. If, however, we do choose to rely on the author's good judgment, then I should say that there is plenty of evidence that some species are affected by rain, but that temperature correlations are doubtful.

The British Herpetological Socicty is collecting data on all British species and in time these should become valuable. The Secretary, at the Zoological Society of London, will be glad to send report forms to any interested person. 


\section{REFERENCES}

BARnes, H. T., and BARnes, T. C. (1932) Nature, I29, 691.

BEACH, F. A. (I948) Hormones and Behaviour (Hoeber, New York).

Bilham, E. G. (1938) The Climate of the British Isles (Macmillan, London).

FARIS, C. (I944) Irish Nat. J., I 8I.

Fisher, R. A. (1935) The Design of Expcriments (Oliver \& Boyd, London).

Fisher, R. A. (I956) Statistical Methods and Scientific Inference (Oliver \& Boyd, London).

JAMES, M. S. (1944) Copeia, 3, 1947-8.

Manley, R. J. (1936) Quart.J. R. Met. Soc., 62, No. 263, I03.

Penman, H. L. (1948) Proc. roy. Soc., Ser. A, No. I93, 20.

Rowan, W. (I938) Biol. Rev., I3, 374.

Royal Meteorological Society, London, Phenological Reports, Annual Publication.

Savage, R. M. (1935) Proc. zool. Soc. Lond., 1, 49-98.

SMith, C. L. (I955) Mem. Soc. Endocrinol., 4, 39-56. 


\section{Chapter 9}

\section{THE BREEDING BEHAVIOUR OF THE FROG}

IN this chapter, I leave the sure ground of established numerical facts for the study of behaviour, in which opinion, however well founded, plays a large part. It is, of course, true that the observations themselves can be objective, but the analysis of the facts is liable to be tinged by the views of the author. Moreover, this is a freld that is devcloping rapidly and contains within itself a variety of apparently opposing ideas, vigorously expounded by competent people. Whenever I come across such scientific controversies, I look at the arguments in the light of the following considerations: (I) It is unlikely that two or more highly competent people, who hold different views, can be separated into groups one of which is all right and the others all wrong. (2) It has been shown with certainty that there is no such thing as an unbiased man. My expectation of meeting one is the same as my expectation of meeting a headless man. (3) Scientists and many others have been brought up, whether they know it or not, on the fourteenth century logical principle, Occam's Razor. This in rough translation reads: "Entities must not be multiplied without necessity." Shorn of its last two words, this is often taken to require that one event can have only one cause, and leads to the vehement rejection of alternative explanations for what appears to be the same event. William of Ockham, or whoever really did originate the principle (for it was not William), never suggested anything of the kind. If we now jump forwards six centuries, and put alongside this principle a remark of a modern thinker, we may be better prepared for what follows in this chapter. Lady Wootton has remarked that it is unnecessary to assume that all the people present in Piccadilly Circus at the same moment are there for the same purpose.

In several of the earlier chapters, it would have been possible to discuss the bchaviour of the tadpoles or frogs in relation to the current views on animal behaviour in general, but the bchaviour aspects were in most cases incidental to the points being dealt with, and I have preferred to postpone a discussion to this chapter, where behaviour predominates. 
At about the turn of the present century, a reaction set in against views on animal behaviour that had prevailed for a long time, in which it was supposed, without much thought, that other animals are actuated by emotions very similar to our own. Loeb (I9I8) showed that in some cases, the movements of animals could be interpreted as mechanical reactions to applied stimuli. For example, an insect that flies towards the light will fly along a line bisecting the angle between two lights of equal intensity, and will fly in a circle if one eye is blackened. Loeb's facts were right, but he stretched his interpretations too far. If I were placed in a dark tunnel with a light at one end, I should almost certainly walk towards the light, but my daily life cannot be summed up by saying that I am positively phototactic. Tinbergen (I95I) has described Loeb's tropism theory as a grotesque simplification. When I was dealing with the behaviour of very young tadpoles, however, I was able to describe their actions as a combination of a kinesis, that is a random movement of restlessness in the absence of enough oxygen, and a negative geotaxis, causing them to swim upwards. This is pure Loeb, but then these are very simple animals, only just capable of movement. When, much later in the lives of the tadpoles, I found a difficulty in explaining the avoidance by small tadpoles of the company of their larger fellows, I suggested that something in tadpole psychology was involved. In this, I was agreeing with Bierens de Haan (1948), who has strongly urged that even the simplest animals have a psychology, and that, little as we may understand of it, we should admit that a full synthesis of the elements of behaviour is impossible without recognizing this as a fact.

In considering the choice of ponds by frogs, I was convinced that the clue lay in the special requirements of the different species, so that each came to seek the environment most suitable to it, by physical means no doubt, but according to a principle of directiveness or adaptiveness, which is close to the ideas of E. S. Russell (I945). Russell has deliberately rejected the mechanistic interpretations of behaviour, because he thinks that they leave out all that is distinctive of life. In most of the following pages, I find that I can interpret what happens very much as I think the behaviourists such as Tinbergen would do. They believe that the approach to the study of animal behaviour should be entirely objective, and should proceed by a step-by-step analysis. Tinbergen in his book has given a very fair appreciation of his own views in relation to the others I have mentioned, and has made it clear that he 
is not disposed to deny Russell's idea of directiveness-in fact he seems to think that it is obviously true, but he does not see that it can be a useful help in the technique of investigation. In a somewhat similar way, he takes pains to explain that the behaviourist school do not assert that animals have no emotions, but only that we cannot know whether they have them or not, and so we cannot usefully employ the concept. Bierens de Haan has severely criticized the behavourists for their statements that we can only observe such states of mind as anger or hunger in ourselves. They do not believe that we can observe such states even in another human, unless speech is used to convey the information. I agree with Bierens de Haan in this respect, for the idea seems to me not only to be contrary to common sense but to be mathematically improbable. We conduct our lives on the assumption that we can detect hunger or anger or pleasure in other men and in other animals by observation in both cases. What seems to have happened is that words invented by our ancestors and applied to man and to other animals have becn captured, philosophically examined, labelled "Not to be used except with reference to yourself" and then returned to circulation. Tinbergen defends this restricted use on the grounds that, if we say that an animal is hungry, we may retard an investigation into why it is hungry by accepting the statement as an explanation. In human affairs, however, we rarely accept such statements as " $\mathrm{B}$ is angry" without asking why B is angry, and I cannot see why we should do so when we are discussing other animals. That one animal, Homo sapiens, is so different from all others that only it has emotions seems to me to involve a probability that cannot be measured, but must be small, when it is considered that the other differences we know are mostly quantitative. The neutral, agnostic attitude is, in that case, not the most logical.

It is possible that somewhere in this controversy, the distinction between the attitudes of mind needed to carry out the process of inductive thought, which is an imaginative act, has become confused with the attitude needed to carry out a deductive investigation. If the directiveness of Russell or the psychology of Bierens de Haan stimulated the production of a hypothesis to be tested according to the objective methods of Tinbergen, science mignt be advanced rather than retarded.

In this chapter, I shall occasionally make use of words on the zoological "Index Expurgatorius" for it secms to me better to use the 
language as it has been handed down to us, and not really likely to confuse anyone reading this kind of book. In case, however, there is anyone who believes, when I say that the female frog "can get rid of the male any time she wants to" that I am suggesting that something like the balcony scene in Romeo and Juliet is enacted in a frog pond, I should explain that although the basic principles are the same, I do think that what happens there is cruder.

With this theoretical digression, we can proceed with a description of what actually happens in the pond, with, I hope, the added interest of watching for the directiveness, the psychology, and the step-by-step analysis.

In the last chapter, we arrived at the point of spawning, but we must retrace our steps a little, for the events I am now about to describe really begin during migration. In some years, but not in others, there is a stage that I have called (1935) the "pre-spawning period." On such occasions, if a pond is approached at night with a light, male frogs will be seen gathered at the spawn sites, usually in the shallows, resting with their heads out of water, but quiet and motionless. The numbers increase night after night, but there is still no sign of breeding. There may even be pairs in amplexus, but no eggs are laid. In one pond, Large Totteridge, I watched this going on every night, and I believe that I was present when breeding actually began. It was a sudden event. At 8.30 I was at the pond alongside the road, and found that all was quiet, although there was much migration. I then went on to the farm that borders the pond and is separated from it by a high fence. While I was there, I heard croaking for the first time that year. Because of the high fence I had to make a long detour to reach the pond, and did not arrive for about ten minutes. By the time I did so, at 9.30, croaking was in full swing. Slight rain had just started. The important point is that the chorus struck up as if at the motion of a conductor's baton, after seventeen nights had elapsed since I saw the first frog sitting in the pond, waiting for something. The rain may have had something to do with it, but we know quite well by now that frogs behave in much the same way all through a drought, so that the rain cannot be an essential sign-stimulus. It is quite possible that when one frog starts all the others follow, but this only transfers the problemwhat makes this frog start? It is, I suggest, something that happens in the pond, which in other years has already happened by the time the first frogs arrive, so that in those years there is no pre-spawn period. 
Indeed, even when there is a pre-spawn period for the first arrivals, for some frogs there is none, for they only reach the pond after breeding has begun.

\section{The Choice of Site}

The most usual place for frogs to lay their eggs is in the shallow water at the edge of the pond, often on a sub-aqueous plateau. As a rule, the same place is chosen every year, so that if the pond is already known, it is possible to walk up to the exact spot, look into it and see the eggs just as in the previous year. There are, however, exceptions. Perhaps the commonest is the use of mats of weed growing in deep water, on which the frogs gather and lay their cggs, in much the same depth of water as when they lay directly on the bottom of the pond. It will be remembered that in Chapter I I described a remarkable case in which a frog laid on a twig just under water in a deep part of the pond, in the shade of a bush.

Running water is rarely used, but again there are exceptions, as I mentioned in Chapter I. These are particularly interesting, and probably important from the theoretical point of view. I have only known five streams where frogs spawned. In one, they spawned at a shallow ford, not in the main stream at all, so that perhaps this hardly counts. In three of the others, spawning was associated with concrete structures. In one, for example, the spawn was laid beside the concrete support for a drain that crossed the stream. In another, a place beside the concrete supports for a road bridge was chosen. In the third, the only one where I saw spawning in progress, the frogs spawned mainly on the concrete bottom where a footbridge crossed the stream. The stream itself is about three feet across, and usually about two feet six inches deep, but varying greatly with the rainfall, as is normal in streams in the London Clay. It rises in Jack's Pond, an artificial lake made by damming up the stream near its source. The water is typical of London Clay. In most years, the frogs spawned in only one place in the stream, within about half a mile of Jack's Pond, and chose the south, downstream side of the footbridge. There they spawned among concrete blocks, on or near a concrete and brick floor forming part of the structure of the bridge itself, and between concrete and brick walls about six feet high, rising sheer from the water. When I visited this place at night, I found that considerable modifications in behaviour were forced on the frogs. It was an extraordinary experience. The 
males were unable to float about as they usually do, for the current would have carried them down. They crawled about on the bed of the stream, with little or no croaking. Apart from this, everything went on normally. Frogs of both sexes were to be seen in the stream heading towards the site, and spent females crouched down in the shallows near by. Large numbers of clumps of spawn were laid, so that the site was not the aberrant choice of a few mistaken frogs. In one year, they spawned more to the south of their usual position, at the shelving natural edge of the stream, just south of the end of the wall. In another year, a few clumps were found higher up stream, where there is a widening of the brook, and in yet another year some spawn was found at another concrete dam lower down. Once a few clumps were found in a pool at the foot of a small concrete spillway leading water out of Jack's Pond, and only a few yards from the pond itself. One or two isolated clumps have been seen, not in every year, at other parts of the stream, but never in Jack's Pond itself. There is another bridge near the pond with a concrete bottom, but spawn has never been seen there. The main spillway is also of concrete, but the current is so swift at this point that it cannot be counted as a possible place. The length of stream that I surveyed is about half a mile, and there are numerous little bays and shallows where the frogs could spawn with less apparent difficulty than in the places they chose. Out of four patches of concrete in this stream, one is the principal site, and spawn has been seen at two of the others. Out of the five streams in which I have seen spawn, it has been on or near concrete in three. A rigid statistical test of an association with concrete is rather difficult, because it is uncertain what length of stream must be counted as a unit for the negative classes, but there is little doubt that this association is not due to chance, and that there is something about concrete in streams that favours the spawning of the frogs. Perhaps it provides a firm substratum for sessile algae.

The other place where large numbers spawned in a stream was in the drainage channel of a gravel quarry. In this area, mechanical excavators are used, and produce numerous ponds after they have taken the sand and gravel away. All are temporary, in the sense that, after excavation, the over-burden (clay that lies over the gravel) is returned and household refuse dumped to fill in the pits. Through the area, a channel is dug to drain the working faces of the pit, and a large electric pump lifts the water at the lower end and produces a fairly rapid flow in the 
channel. Frogs are plentiful, far more so than in the surrounding country, and spawn in many of the pools, and also on a weed mat in the main stream of the drainage channel. The stream is rich in vegetation, and the weed of the mat was encrusted with sessile algac. It was no isolated aberration, for there were probably a hundred clumps on the mat, as far as I could judge from the bank, for the water was too deep for me to reach the spawn by wading. The conditions in this quarry, where frogs flourish, bears a remarkable resemblance to the glacial moraines among which perhaps this species was evolved. Not only is the sand and gravel of Quaternary glacial origin, but the machines pile it up into ridges of shifting material, and there is running water everywherc, much as in natural moraines of the present day. I have seen tadpoles of this species in a pool in just such loose material beside the Rhône, below the snout of the glacier.

\section{Pollution}

Many ponds are polluted by cattle and in other ways. I think that this is a favourable factor. In the stream out of Jack's Pond, there were several sources of pollution. The main one was derived from a large heap of slaughterhouse refuse, the accumulation of years, and continually replenished. There were smaller sources from the drainings from a cowshed and from a very poor sewage purification plant. In one year, one clump of spawn was laid almost exactly in the middle of the patch of green, composed of Euglena, that marked the cntry of the pollution from the refuse heap into the main stream. The mud at the main spawn site was composed of diatoms in great variety and unusually large size. Besides this case, I have known of two other spawn sites in which sewage was present, and have had another reported to me.

\section{The Breeding Behaviour}

The earliest description of the breeding behaviour of this animal is apparently that of Swammerdam (I637-I680, English translation of I758). No important original observations were made until Rösel von Rosenhof (1758), an Austrian Count, published his book on the European Anura occurring near his home. Rösel's book was sumptuously produced, with many beautiful coloured plates from his own paintings. It would be quite wrong to suppose that these accounts are merely part of scientific history. At the cost of much labour, I had already made my observations before I saw these books, and I read 
them with a growing sense of apprehension, feeling that I had been completely anticipated in my work. In the end I found that my predecessors had left something for me to describe. I do not think that the other accounts in the literature are original-they are not claimed to be, and occur in contexts in which compilation was to be expected.

\section{The Events in the Pond}

For the field study I selected a suitable pond, and made observations almost every night of the season. Frogs at night pay little attention to an observer behind a light, and continue with their breeding behaviour in its beams. Artificial light has appeared too late in their evolution to have any meaning for them, and, as with many other animals, it is only events that have mattered in their history that have left responses in the animals. Moreover, they are only temporarily affected by daytime disturbances. On one afternoon during the observations, I passed the pond and saw with alarm that some boys were punting violently across the very spot where I hoped to be that night. I need not have feared. As I walked up to the pond that night, I heard the familiar croaking, and there were the frogs, not merely any frogs, but the labelled individuals that I was observing. Frogs must have been disturbed for thousands of years by large animals coming down to drink at the shallow places that they choose for spawning, and the boys do not represent anything essentially different.

Many of the frogs were tagged with small paper labels, large enough for the numbers to be read in many cases without even catching the frog. I could therefore make a roll-call by standing among them and writing down the numbers as they swam about. There were usually about sixty frogs present each night of the season, which lasted for twelve nights. I was present for eleven of them, usually for about two hours on each night, so that I probably saw most of the typical behaviour. Table 9 shows the results. Several males secured more than one female in the season. The frog AI 8 was mated with a different female on each of three successive nights. Since the numbers of the sexes are about equal, this must imply that other frogs do not secure a mate at all in that year. It can easily be seen how important it is for a male frog to arrive at the pond in good time, for otherwise his chances of leaving offspring are much diminished. This functional polygamy also goes far to explain the intensity of the competition between the males, of which I shall have more to say later in this chapter. With 
one exception, which was possibly a mistake, I saw no female a second night, and in the I934 paper I concluded that the females are not in amplexus for more than one night. This was premature, and in the 1935 paper I pointed out that there are conditions under which the females remain in amplexus for days during the pre-spawning season.

The numbers of frogs in this pond remained similar until nearly the end of the season. Since a good many tagged males were not seen again, the inference is that there is some coming and going among the males. One or two were very regular in their attendance, for example As; others absented themselves for long periods, for example $\mathrm{A}_{4}$ and $\mathrm{A}_{9}$.

The difference between the sexes is not quite adequately expressed by the usual statement that the males arrive first, followed by the females. Most of the males do arrive before most of the females but the chief difference is that the females arrive, or at least enter the spawning site a few on each night, but large numbers of males are already there, and a smaller stream of males continues to arrive throughout the season.

\section{Voices}

The normal croak of the male is a harsh sound without much carrying power. A breeding chorus of about a thousand males in Large Totteridge Pond was sometimes inaudible fifty yards from the pond. The warning croak used when one male touches another is a quicker sound, about two or four to a second, somewhat resembling the grunt of a pig. There is a good deal of variation in both notes at different times and in different frogs, and the two voices are not so sharply distinguished from one another as, for example, in the toads, Bufo bufo or Bombina variegata (Savage, 1934, 1932).

The term "Call-note" for the ordinary croak of this species is not very appropriate. In other Anura, for example B. bufo, the male takes up a more or less definite station from which he calls. The note could clearly function for attracting the female, although whether it does so is uncertain. In $R$. temporaria a male does not stay still but jostles continually in a crowd with his croaking companions. The croak is communal, and while perhaps effective over a short range in attracting a female to the spawning sitc, cannot function for attracting a female to any particular male. Ponds with very few frogs in them may be quite silent, and vigorous croaking is characteristic of a crowd of frogs and not of individuals. Noble and Aronson (1942) have pointed out 


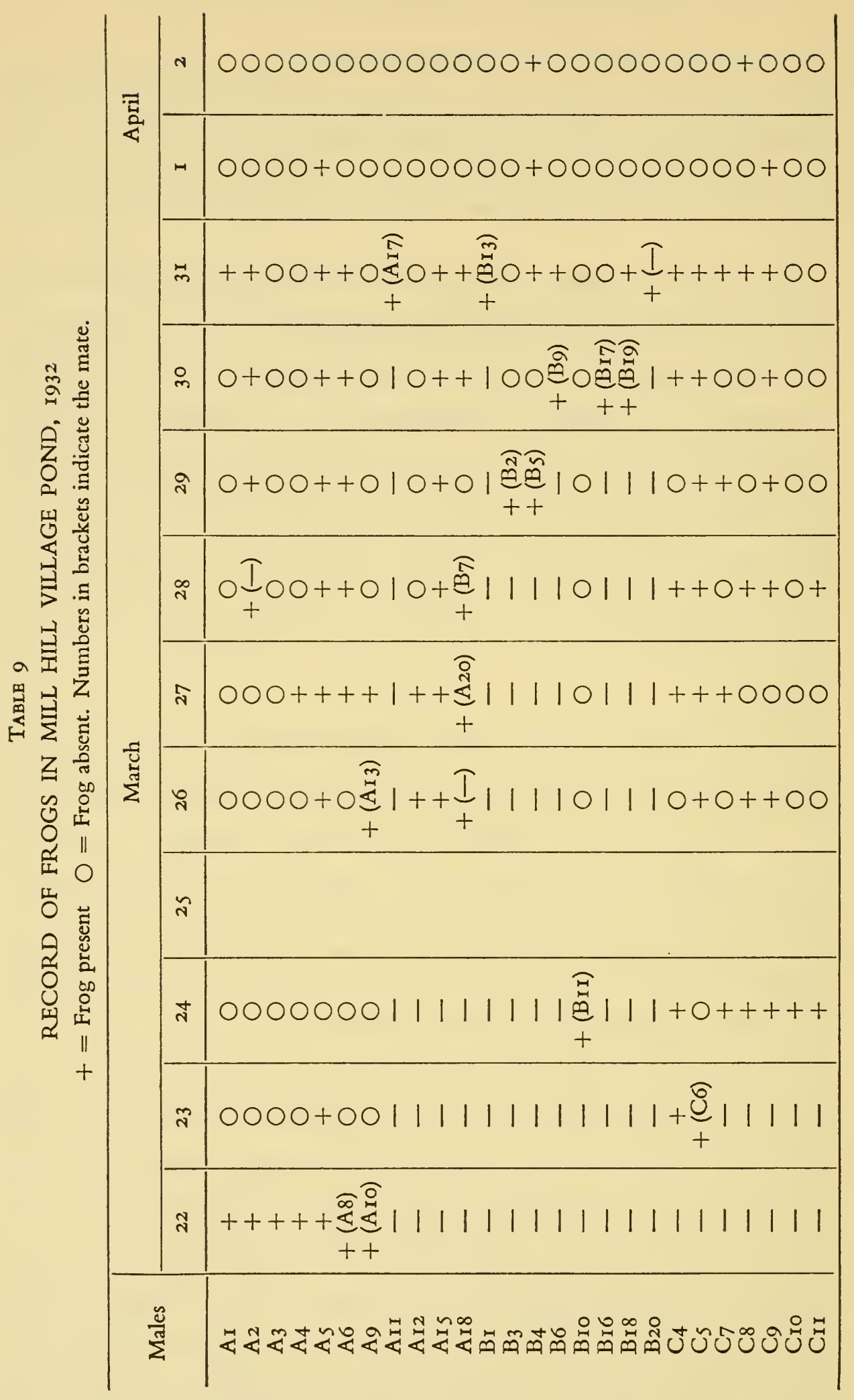




\begin{tabular}{|c|c|c|c|}
\hline \multirow{2}{*}{ 荌 } & a & 0000000 & 0000000000000000000 \\
\hline & - & 0000000 & 0000000000000000000 \\
\hline \multirow{10}{*}{ 离 } & $\stackrel{m}{m}$ & $0+000+0$ & 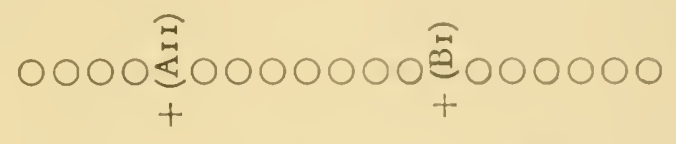 \\
\hline & 일 & 0000000 & 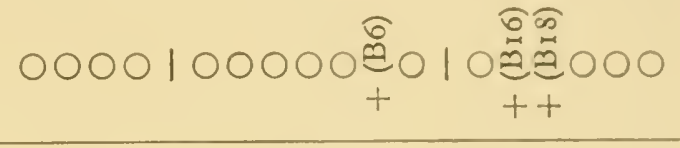 \\
\hline & iे & $0+00++0$ & 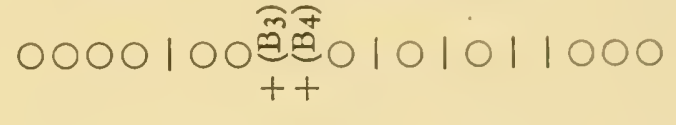 \\
\hline & 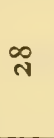 & $0000+00$ & 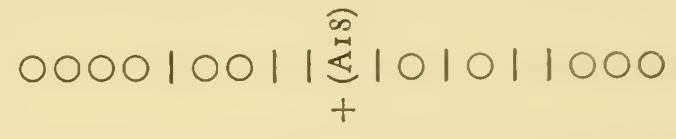 \\
\hline & $\hat{A}$ & $\underset{+}{\stackrel{f}{\vec{B}}}++\underset{+}{I}+0$ & 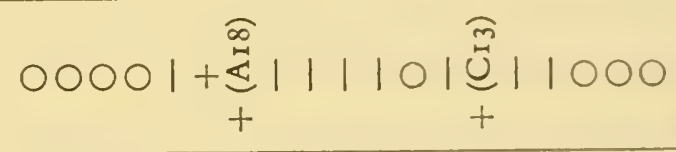 \\
\hline & ה: & $00++0+0$ & $00 \underset{+}{\widehat{a}}+111111101111000$ \\
\hline & $\tilde{\tau}$ & & \\
\hline & 4 & $++++++\underset{+}{\stackrel{\widehat{্}}{\mathscr{C}}}$ & $001|1| 1|1|\left|\frac{\hat{g}}{+}\right| 1 \mid 10+\underset{+}{\hat{d}}$ \\
\hline & $\tilde{\sim}$ & 1111111 & $001111111111111 \underbrace{\tilde{v}}_{+} \mid 1$ \\
\hline & ส & 1111111 & 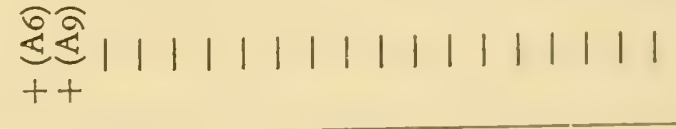 \\
\hline 2 & & 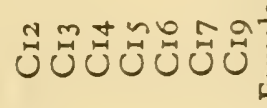 & 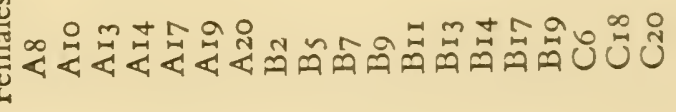 \\
\hline
\end{tabular}


that no one has demonstrated in any species of Rana that the sex call attracts the female.

\section{Sex Recognition}

The methods by which animals recognize the sex of each other are often complicated, and may not be at all obvious until the behaviour has been closely studied. The frog is no exception. Pioneer work on sex recognition in frogs, but not on this species, was carried out by Noble and Farris (1929), using the American Wood Frog, R. sylvatica, considered by systematists to be closely related. Since then, and since my paper, other studies have appeared, for example W. M. S. Russell (I955) on Xenopus laevis, and Aronson (1944), on American species, so that it is now possible to discuss the question with a reasonably broad view, especially as the more general work on animal behaviour can contribute to a better understanding.

It is not possible to see all the details in a pond, so that I made a special aquarium for the observations. This had a glass bottom and a mirror back, and, by lighting it from below, there was scarcely any chance that an important action would pass unobserved, for I had only to move my eyes to see, in a second or so, several different aspects of the same pair of frogs, either a direct view, one in the back mirror, or, reflected in another mirror placed on the table under the aquarium, a view from underneath.

In all the period of observation, both at the ponds and in the tank, only rarely did one male vigorously grab another, and even then the embraces lasted only a few seconds. The males do not invariably give either their sex-warning croak or their ordinary croak when mere contact occurs. On the other hand, both females introduced into the tank were seized within about five minutes. In the description of the behaviour of the spent females (Fig. 46), it will be seen that these females, which resemble the males in figure, are frequently seized vigorously. It is impossible to reconcile these observations with those of Noble and Farris on the Wood Frog. In these animals the male seizes another indiscriminately. If the seized animal is a female, she possesses a stout figure and remains silent, but a male has a slender figure and gives out a short rapidly repeated croak that acts as an indication of his sex. Cummins (I920) and Liu (I93I-2), attached importance to the repulsive action of the male that is seized. Release or retention depends on these differences of behaviour and characteristics. 
In $R$. temporaria it secms that a female is recognized positively by some character that is peculiar and which she retains after oviposition. The factors that in other species are effective for sex-recognition merely determine in this species whether she will be retained or released after she has been recognized as a female and seized. The recognition occurs only on contact. Owing to the angle at which the animals float, it is the fingers of one frog that come into contact with the back of another but, below water, it is the nose of the animal that touches first. Now the skin of a brecding femalc of this species is very noticeably different from that of a male. In the female there appear on the posterior part of the back, thighs, flanks and the sides of the head a large number of so-called "pearly granulations" that were described and investigated in detail by Huber (I887). He found that, although the structures themselves are horny and impart to the skin a roughness like sandpaper, the bases are provided with a special innervation, and he concluded that they have a tactile function. Whatever may be the sensation that the female derives from them, and whatever part they may play in her life, it seems likely that they have a great importance for the males, for they provide him with a means of recognizing his mate. I found that it was easy to sort males from females by touch alone. The contrast is heightened by the very slippery skin of the males, which is developed also in the breeding scason. There is no actual proof that these structures act in the way I suggest, except the observations of the intense action of the males as they brushed past the females.

Sight also plays a part. Sometimes, a male frog would catch sight of his own reflection in the mirror and swim croaking towards his image. This confronting of one male by another is a noticeable feature of the behaviour in the ponds. It is possible that this is one of the ways in which the breeding colony is kept compact, and, perhaps, the function of the male sex-croak is to draw the males together.

\section{Fighting}

It is now known that, in general, the fighting of animals is mainly bluff. The vanquished animal breaks off the fight before he receives much damage, and the victor does not pursuc his victory. The ferocity of man towards his own species is probably unparalleled. Tinbergen (r95I, p. I77) in discussing this, considers that there is, even in man, the same instinctive inhibition of the fighting drive, and thinks that it is modern long-range arms that have facilitated wholesale slaughter by 
preventing the user of the arms from seeing the results of his actions. But the Greeks slaughtered each other in hand-to-hand combat, and Homer leaves out few details of the technique. The mass-production methods of Tamerlane the Great, although only manual, have but recently been excelled. My own ideas on this perplexing subject suggest that on the geological time-scale, man has temporarily exempted himself from the consequences of bellicosity that have eliminated this tendency in other animals, and that natural selection is now overtaking him. We should therefore not be surprised to find that frogs do not fight to the death. We should, however, be quite wrong to suppose that they do not fight: they certainly do, and very vigorously, but with an exceptional lack of damage to each other. In fact, the victor leaves not a mark upon his opponent, for the very good reason that he has no weapons. He has no claws, and his teeth are used only for holding prey.

In the breeding season the males of most species of Anura develop the so-called "nuptial pads" on their thumbs. It was formerly believed that these pads, consisting of a patch of rough and thickened skin, were for holding a reluctant female. In fact, however, they are part of the equipment of a wrestler, used for preventing the abduction of a far from unwilling female by a rival male. The method of fighting in this and other species is a trial of strength, in which one male seizes any available part of a female in the possession of another male, and attempts to dislodge his rival by hooking his feet against the rival, and then pushing with all his strength. The vigour of these struggles is terrific, the contestants rolling over and over in the water, with the female playing a passive part. Sometimes, more than one frog attempts to dislodge the original male, so that a ball of animals can be seen tumbling this way and that way as the battle goes on. I have never seen a wellplaced frog dislodged, but I have little doubt that a weak one, or one that had not quite secured himself in position, would be hard put to it to maintain his place. In Bombina variegata, I have seen a successful attack on a pair of Bombina bombina, in which the attacker, a slightly more powerful animal, managed to hook his feet under the chin of the sitting male. With one mighty shove, the unfortunate $B$. bombina was bent backwards, and released his hold, whereupon the victorious $B$. variegata settled down in possession. It is in this species that the final argument in favour of my view that nuptial pads are a kind of weapon is to be found, for $B$. variegata has not only pads on its thumbs, 
but has them on the soles of its fect as well. These are obviously quite useless for holding the female, but are in just the right place for providing a frictional foothold on another male, as I have just described. In the Midwife Toad, Alytes obstetricans, there are no nuptial pads. Fatio (I872) attributed this to the short time of amplexus, and much

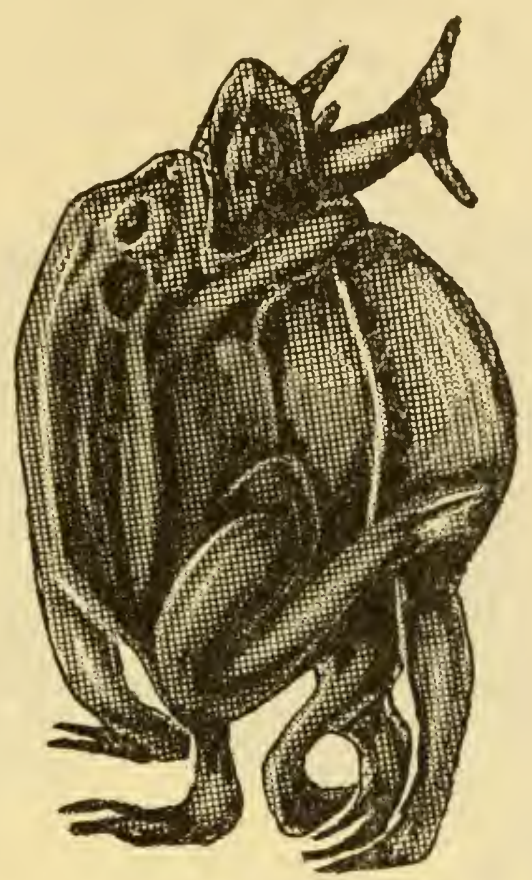

Fig. 42. A Fight

The male in possession is on the left. The attacking male has secured a hold on the ventral side of the female, with his head and arms hidden from view behind her head. His legs are extended downtvards, and are the two on the right. They have probably been pushed there by the other male, whose right foot has just pushed his opponent's left downwards. His left foot has probably completed a similar movement, and has slipped away to the left. The female takes no part in these struggles, and remains immobile, with legs extended. Her legs can be seen with feet turned outwards, below. The extraordinary position of the legs is characteristic-frogs can place their legs in what seem to be the most improbable positions. For example, a frog can rub its own back with the soles of its feet.

later Kammerer (1923) considered that the reason for the absence of the pads was that, in this species, mating takes place on land, so that the skin of the female is not slippery. Mating in Alytes, however, occurs in the burrow made by the male, to which the female goes attracted by the call of the male. Males are said to dispute about the female, but the details are probably different. It is probably this and not the habit of breeding in water that is the important point. 


\section{Oviposition}

The actions of spawning in Anura are so rapid that the most rigid attention is needed if some feature of the process is not to be missed. The tank I have described above was made for close observations, and the events showed that all its conveniences were needed.

I began by bringing two females and seven males from a pond, and putting them into the tank, filled with tap water. No spawn was laid that night, nor for the next three days. I then transferred one pair to

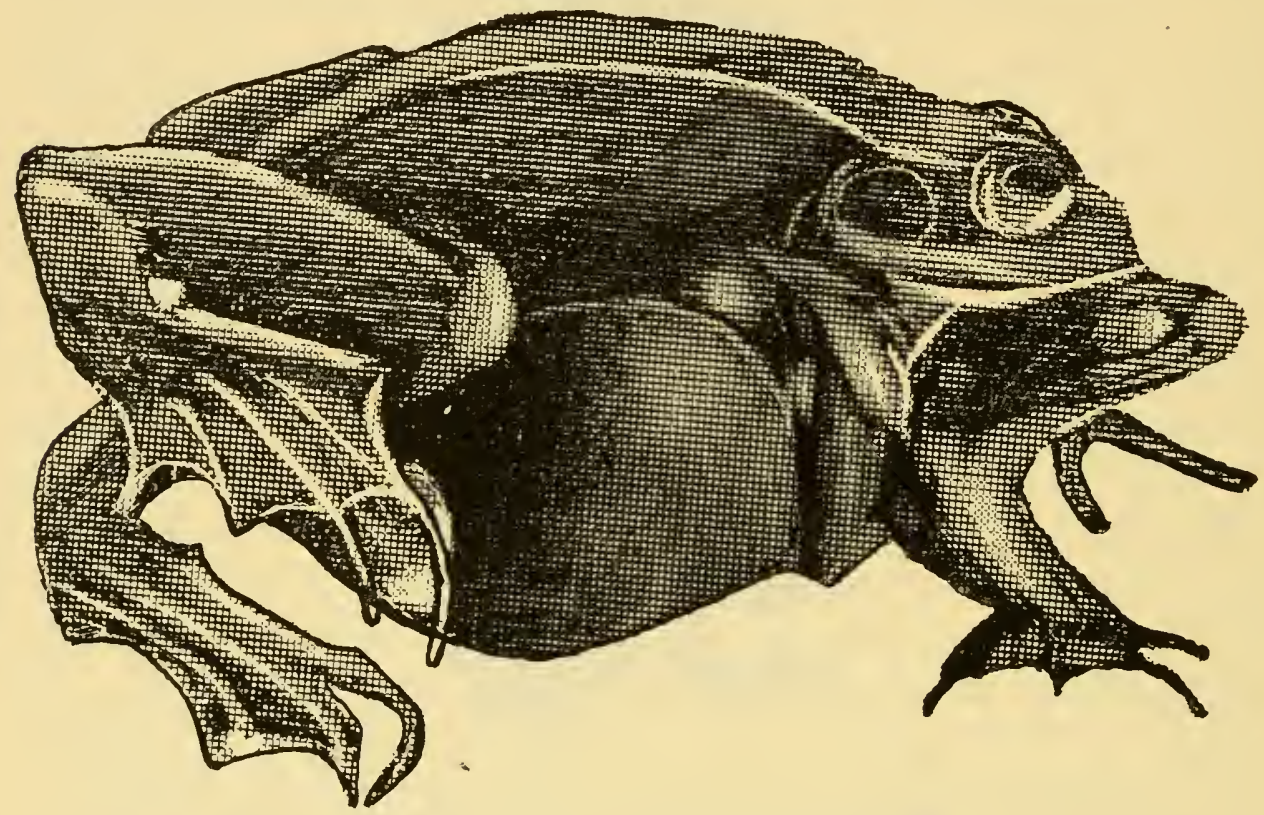

FIG. 43. A pair of frogs in amplexus

Note the defensive position of the feet of the male, posed ready to fend off an attack from the rear. Note also the pectoral grip and compare with Fig. 45. The female is full of eggs and has her eyes shut. Her legs are used for swimming and do not have the defensive angle that the male adopts.

another aquarium with sand on the bottom, but there was no spawn after another day. Both pairs were then removed to an outdoor terrarium with a pool that had been established for two years, where they spawned within twenty-four hours. Although this was not proof, it suggested that pond water might help to produce spawning, so that I made another attempt by filling the tank with pond water, and putting in it five pairs and three males. I guessed that spawning might take place in the early hours of the morning, so I began observations at 4.00 a.m. At that hour one pair had already spawned. Nothing of interest occurred until 5.45, when one of the females made a few 
ill-defined scrambling movements, and 5.55 spawning occurred clear away from other frogs, on the glass bottom of the tank. It was a remarkable experience. Not more than five seconds clapse between the first appearance of eggs at the cloaca, and the completion of expulsion of the whole mass of eggs. They are ejected forcibly, and stream over the surface of the glass, rapidly at first, then more slowly, like hot pitch flowing over a cold surface. The ejection of the eggs was apparently aided by the hands of the female, which were pressed so hard on her abdomen that depressions were visible. Possibly the greater part of the propulsive power needed for this very rapid cxpulsion is

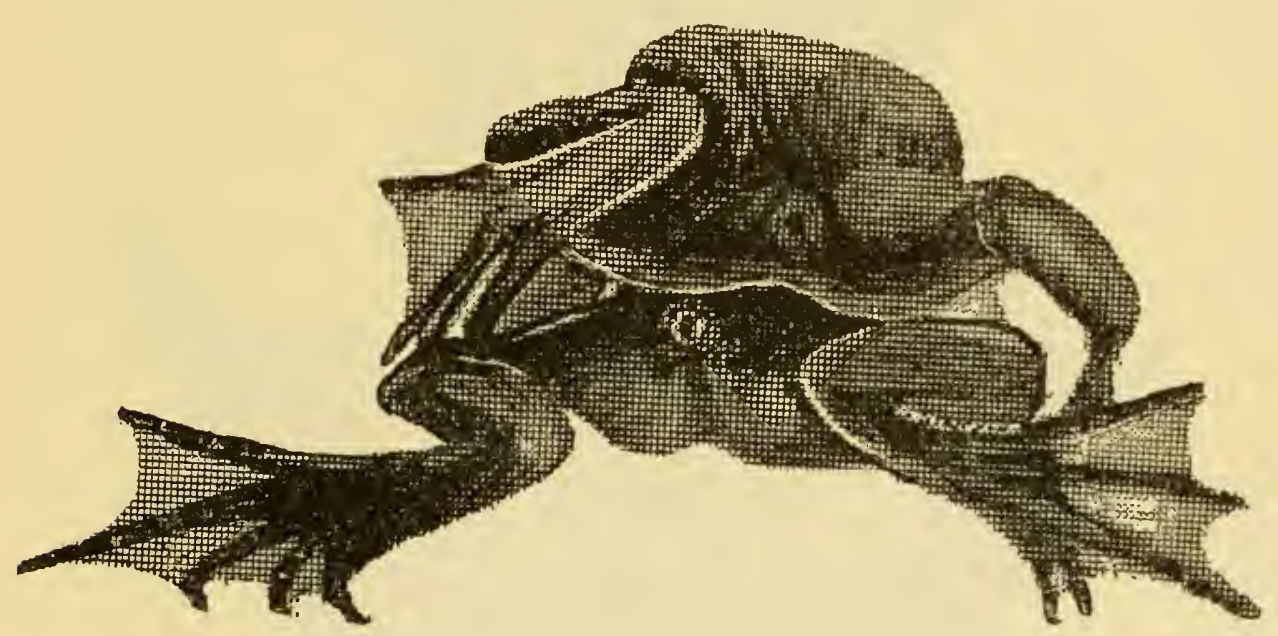

FIG. 44. Rear View of a Pair of Frogs

Note again the defensive position of the feet of the male, quite different from that of the female. Note also the position of the vent of the female. A stream of eggs being squirted violently out of the vent would almost certainly brush past the ventral surface of the male, and this probably provided the stimulus for the emission of sperm.

provided by the muscles of the female's arms. Waring, Landgrebe and Neill (I94I) were puzzled to account for the propulsive force in this species, and said that they searched the literature without finding a description of oviposition, although there are at least three. It really adds interest to find that these authors had independently realized that there was something remarkable to explain, for the weak abdominal muscles do not seem sufficient. The male has often been credited with helping expulsion, but his arms are placed too far forward.

Two more pairs spawned in the tank, at 6.20 and at 7.00 a.m., and I was able to confirm the above observations. In one case, the female clambered to the top of one of the previously laid clumps, and laid her 
eggs there, even though this spot was a very small fraction of the available space. This behaviour is often found in the ponds. The recoil of the issuing eggs caused the pair to glide into view as I was watching

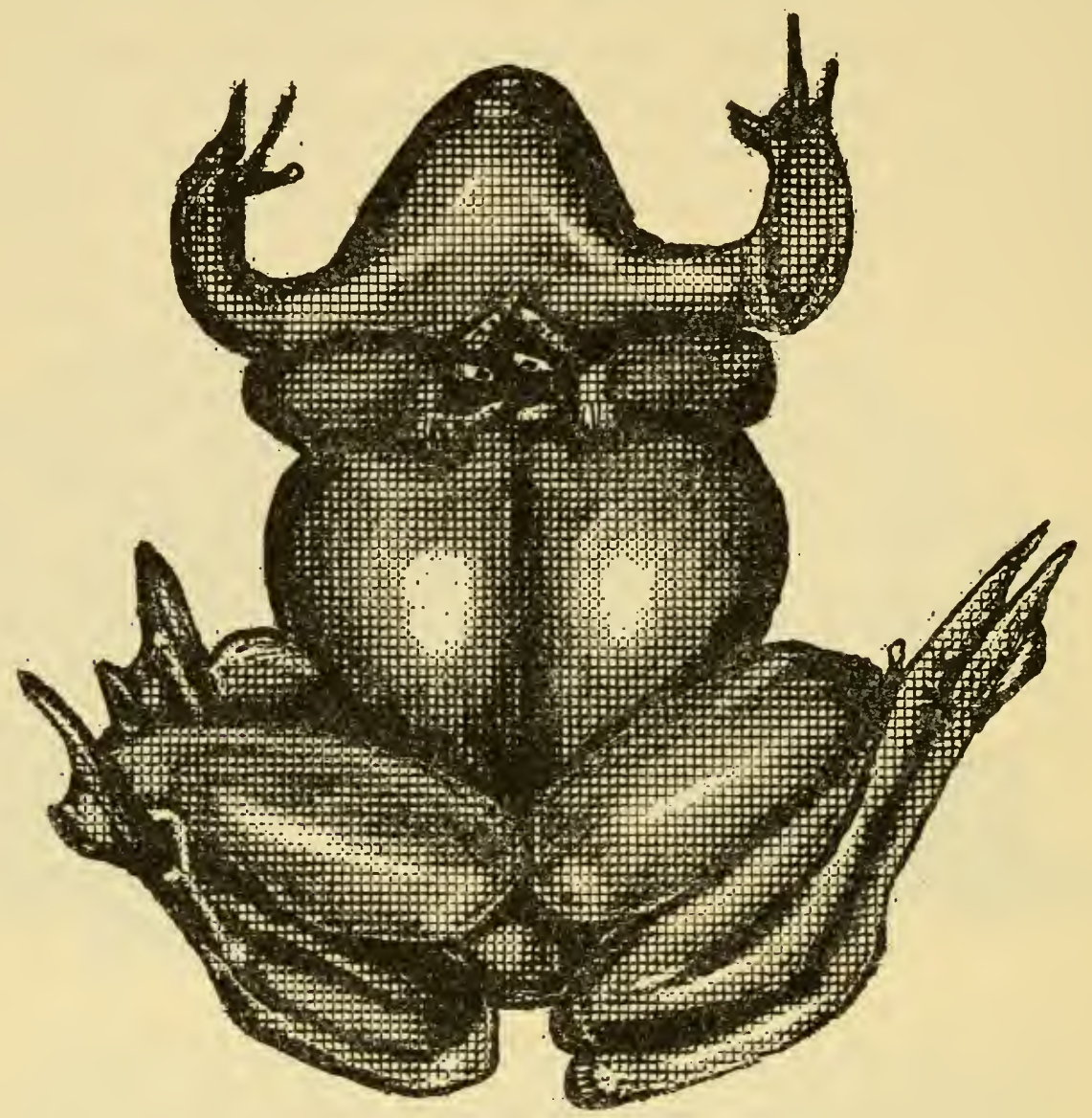

Fig. 45. A View of a Pair as Seen in the Lower Mirror of the Tank

Note that the fingers of the male touch or overlap, and that the arms completely encircle the female, well forward of the main mass of eggs in the body of the female, and so able to do little to expel the eggs by pressure. In this pair, the feet of the two frogs are in contact. Each of the two long toes on the right of the picture belongs to a different frog.

the lower mirror, and it was the position of the arms of the female that drew my attention to the fact that she was spawning.

\section{Sperm Emission Stimulus}

It is essential in the Anura that the emission of sperm should occur at the same moment as the expulsion of the eggs, for fertilization is only possible for a short time afterwards, probably because, as explained in Chapter I, precipitation of the outer globulin layer is so rapid. In 
each of the species I have studied, there is a special sign-stimulus that ensures synchronization. In Bombina variegata, the female, just before she begins her swift spinning movement round the weed on which she lays her few eggs, reaches back with her foot and rubs the male on the region of his symphysis pubis. He immediately responds by expelling sperm, and the pair spin round the weed rather faster than the eye can follow, the cggs being laid during this astonishing manouvre. In the Common Toad, Bufo bufo, the female stretches herself, and this acts as a sign-stimulus for the male to place his fect at the cloaca of the female. A part of the egg string is then extruded, and glides over the feet of the male, who then pumps sperm over the eggs. In $R$. temporaria, there is no definite action of this kind, and I think that the sperm emission stimulus is provided by the stream of eggs striking the male over the symphysis pubis, as in Bombina. No similar stimulus ever reaches the male during his life in the pond, for although he crawls over and among eggs already laid by other frogs, these are slippery, and quite unlike the sticky newly-laid spawn.

\section{Dismissal Stimulus}

In the I934 paper, I used the term "release stimulus" to denote the stimulus given by the female to the male, which induces him to release his hold upon her. "Release mechanisms" and "releasers" have now come to mean something more general in the literature on animal behaviour, namely, any sign-stimulus that "releases" some kind of behaviour in another animal. For example, the gaping reaction of young thrushes is "released" by a moving object over $3 \mathrm{~mm}$ in diameter above the horizontal plane passing through the nestling's eyes (Tinbergen, I95I). Curiously enough, my "release stimulus" is also a releaser in this new sense, but it is better to avoid using the same word for two things. W. M. S. Russell found the same difficulty and used the term "unclasping stimulus." This has a rather narrower meaning than my term.

The female $R$. temporaria that has just deposited her eggs is now a different animal both in appearance and behaviour. She is now at least as thin as a male (Fig. 46), a fact that contributes to her release if she is molested while she is making her way out of the pond. She is, however, still provided with the badge of her sex, the horny granules, and she is liable to be seized by any male that touches her. When this occurs, she no longer feigns death or remains silent, but behaves 
exactly as a male. Voiceless before, she now grunts vigorously, with a note that is perceptibly but not greatly different from the male grunt. The combination of this warning note and the lack of stoutness that caused the male to retain her until she had laid her eggs results in a fairly rapid release. There is now no vigour in the grip of the males, but spent females may often be retained for several minutes. It seems improbable that a spent female would have much difficulty in
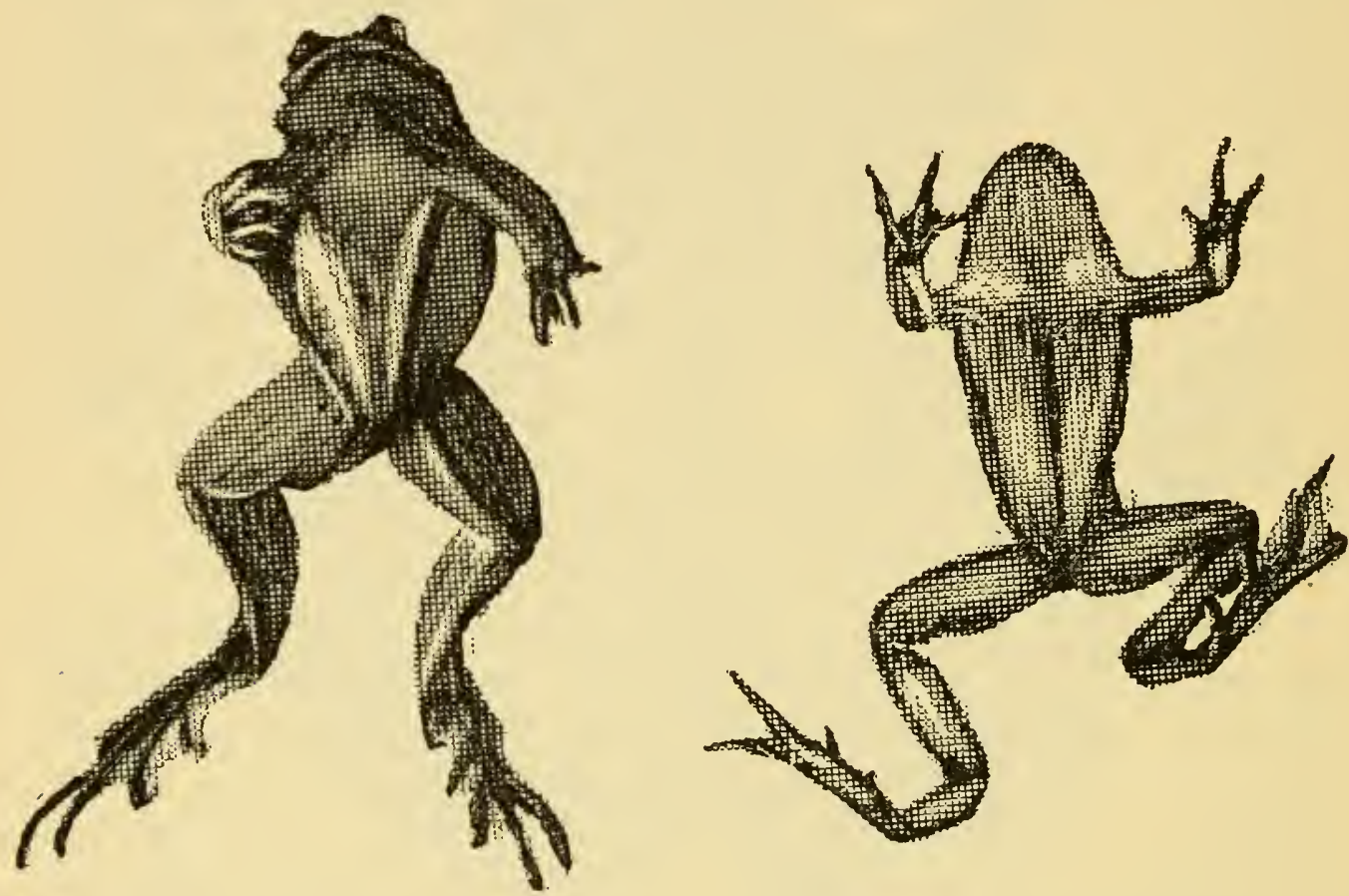

FIg. 46. These Drawings Show the Difference between the Build of a Male, on the Left, and the Spent Female on the Right The male, a more powerfully built animal, is actually stouter than the slightly built female, so that the difference in figure cannot explain the frequent seizure of spent females by males. The male was standing in water, against the glass of the tank. The female was resting on the glass bottom, and is seen as in the lower mirror.

making her way through a crowd of males, but she would often be detained for short periods.

From my observations on this species, and also on Bufo bufo, and Bombina variegata, I concluded that in each case the female can get rid of the male any time she wants to, merely by using a dismissal stimulus, different in each species. In $B$. bufo, it seems that it has a somewhat negative character. If, when the complicated series of movements that usually precedes the emission of eggs is complete, and the male has 
his feet at her cloaca, no eggs emerge, the male immediately loses his hold and swims away. If a female that has finished spawning is again seized by a male, she has only to go through these motions again to dismiss him. It is a remarkable sight-the vigorous little male acts as if he is under a spell. In Bombina variegata the female makes herself as thin as possible, and crawls, mewing plaintively. This casts a spell on the male, who rclaxes his grip. Gingerly, mewing all the time, the female crawls out of his arms, appearing to take care not to touch the male and so stimulate him to grip her again. It is a delicatc operation, and may not succeed the first time, but as in the other species, I do not believe that she is ever retained for long if she wants to get away. All she has to do is to administer the dismissal stimulus.

To conclude this account of the dismissal stimulus in $R$. temporaria, the female is capable of using her voice before she has laid her eggs. The only pair that did not spawn during my successful night of observations was left in the tank, now filled with tap water. After some days, the frogs were found to have separated, and the female, although still full of eggs, grunted and dodged away when touched or seized by the male. Not much importance can be attached to the fact that he did not retain her, for he was by this time probably somewhat exhausted, but the observation seems to show that some change occurred in the female that caused rejection of the male by the use of the dismissal stimulus. Her silence during normal breeding is not due to mechanical inability to croak, because she is too full of eggs, but to the fact that she is then ready to accept the male. In fact, throughout the season, in all three species, it is the female that is really in charge of the events. It is she that swims to the spawning site, chooses the time and place for laying the eggs, and departs when her task is done.

Noble and Farris (1929), Noble and Aronson (1942), and Aronson (1944), have contributed important observations of the sexual behaviour of American frogs and toads. In reading their work, I am struck both by the resemblances and the differences from that of $R$. temporaria. Noble and Farris's paper is particularly interesting, because the frog they studied was the American Wood Frog, R. sylvatica, closely related to $R$. temporaria. Anyone who compares their accouint with those of my two predecessors and myself, must conclude that the differences are, in places, more than can be accounted for by differences in the observers. Sex-recognition, Noble and Farris think, is accomplished by the males embracing other frogs regardless of sex, and 
releasing those that are not fat enough to be females with eggs, and which croak. They considered that the females are released after spawning merely because they become thinner. In R. pipiens, Noble and Aronson consider that the cessation of the female's warning croak is due to the pressure of the eggs, but in R. temporaria this is not so, as can be seen from my description of the female that croaked although she had not laid her eggs, but had probably retained them too long. Moreover, the dismissal sign-stimulus, which, according to my observations, is remarkably effective, was not interpreted in the same way. For example, Aronson pointed out that observations on a number of American species of Rana had shown that the warning croak of the female does not return for several hours after spawning. Noble and Aronson suggested that the dismissal stimulus was probably the resultant of a number of factors, including (I) the ejaculations of the male, (2) the reduction of the girth of the female, (3) the cessation of the female oviposition reflexes, (4) the movement of the female from the egg-laying posture.

Now these observations are, in my opinion, among the best of the modern work, but I think that the authors have transferred rather too easily observations on their own species to others. Among the European Ranas for example, only $R$. temporaria and $R$. terrestris have the horny granules, so that, even in Europe, only these species could show sex-recognition by this means. It is impossible to reconcile the intense grabbing of females by males of $R$. temporaria with Noble and Farris's description of events in $R$. sylvatica.

I think we should recognize that the pattern of behaviour differs much in different species, and that probably neither the American workers nor I were mistaken in what we saw. Much the same can be said about the dismissal stimulus. Aronson found that in Hyla andersonii there was the back-arching sign that I thought was part of the dismissal stimulus in B. bufo. He thought that this alone was the dismissal stimulus. I had suggested that it was really the lack of emission of the eggs after this back-arching that was the true stimulus. Aronson thought that this could not be so in his species, because the back-arching sometimes occurred for a whole day without the male releasing. I have also seen similar unsuccessful attempts to dismiss the male in B. bufo. It is characteristic of instinctive behaviour that it sometimes fails (Tinbergen, I95I, p. 27), and I merely thought that I was witnessing an attempt at dismissal that failed, without considering that it 
invalidated the truth of the hypothesis that it was the absence of eggs that was the real stimulus. When watching normal oviposition in this species, it was most striking to sec the phase of behaviour that usually preceded oviposition repeated at the end of the whole process (which in this species goes on for half an hour or more), but with no emergence of eggs. Immediate dismissal followed as if by magic. I think we have here an example of the too vigorous use of Occam's razor. In other directions, these authors are above criticism of this kind. For example, they admit that the total dismissal stimulus is a complex of a number of separate stimuli, and have not fallen into the crror of supposing that, having found one effective sign-stimulus, there cannot be another.

In fact, it has been found that in general an animal attains the accuracy of reactions it needs by requiring for full release several different sign-stimuli. It is possible to express this mathematically. Let us suppose that a frog needs to recognize its mate with something like complete certainty. Now let us suppose that one sign is the sex croak, but that in a crowded pond, mistakes are so casy that he may be wrong one time in five. Now suppose that the girth of the femalc is another sign, with a probability of being wrong of one in ten, for all male frogs are not the same size. Next suppose that a third sign is the warning croak, with a chance of being wrong of once in six. Probabilities are combined as their products, so that the probability of all these signs being wrong at the same time is only one in 300 , and this might be near enough to certainty to scrve the purpose. Note that this accuracy has been reached by the use of only three very imperfect signs. Of course this is just what we do ourselves-we do not usually recognize other people or things by one infallible sign, but by the combination of a number of signs, none of which may be quite distinctive, but which, together, tell us at once what we want to know.

The American workers clearly distinguished between the unnatural extrusion of eggs that results from injection of hormones in the absence of the male, and natural oviposition. They used hormone injections when they wanted to observe, but found that although eggs were extruded from injected females, there was no normal behaviour in the absence of an excited male. I share their opinion that Waring, Landgrebe and Neill (I94I) were not witnessing normal oviposition in $R$. temporaria, but merely extrusion of eggs.

I think it is, however, now possible to see the part played by the 
hormones. They seem to form intermediate links in the whole chain of events connecting the environment with the act of oviposition, but not the end links. The environmental factors considered in the last chapter must surely act on the nervous system of the animals. These nervous stimuli perhaps act on the pituitary and induce a state of oestrus. This itself does not produce normal oviposition, but in the presence of a male and certain other requirements, some of which may have been absent from Noble and Aronson's experiments (for they were not quite natural observations, after all), eggs are laid, and not merely extruded. This distinction must again be nervous in origin.

The circle of the frog's life, with which I began this book, is now complete, for in passing from stone to stone in our progress, we have come again to eggs in a pond. If in travelling with me round the circle, the reader has had as much pleasure as I have had in making the observations, reading about the work of others, and writing the results of my thoughts about it all, then I shall not have laboured in vain.

\section{REFERENCES}

Aronson, L. R. (1944) Amer. Mus. Novit., I250.

Bierens de HaAn, J. A. (1948) Animal Psychology: its Nature and its Problems (Hutchinson, London).

Cummins, H. (1920) J. exp. Zool., 30, 325-43.

Fatio, V. (1872) Faune des Vertèbres de la Suisse (George, Geneva).

Huber, O. (1887) Z. wiss. Zool., 45, 664.

Kammerer, P. (I923) Nature, Lond., I2 May, 637.

Liv, C. C. (193I) Peking nat. Hist. Bull., 6, 2, 43-60.

LOEB, J. (I9I 8) Forced Movements, Tropisms, and Animal Conduct (Philadelphia).

Noble, G. K. and Aronson, L. (1942) Bull. Amer. Mus. nat. Hist., 80, No. S,

I27-42.

Noble, G. K. and Farris, E. J. (1929) Amer. Mus. Novit., 363, I-I7.

Rösel von RosenhoF, A. (I758) Historia Naturalis Ranarum Nostratium (Nurenberg).

Russeln, E. S. (1945) The Directiveness of Organic Activities (Cambridge Univ. Press).

Russel, W. M. S. (I955) Behaviour, 7, II4-85.

Savage, R. M. (1932) Proc. zool. Soc. Lond., 4, 889-98.

Savage, R. M. (1934) Proc. zool. Soc. Lond., I, 55-70.

Savage, R. M. (1935) Proc. zool. Soc. Lond., I, 49-98.

Swammerdam, J. (1758) The Book of Nature (English Trans).

Tinbergen, N. (I95I) The Study of Instinct (Clarendon Press, Oxford).

Wartng, H., LANDGREBE, F. W. and Neill, R. M. (I94I) J. exp. Biol., I8, I I-25. 


\section{Chapter Io}

\section{METHODS}

IN this chapter, I find for the first time that I am not talking to mysslf, but addressing at least three kinds of people. Some zoologists may find some of the methods of use to them, and, in particular, I can draw attention to some neglected fields of study in which they could be applied. Then there is the growing group of people who, in this technical age, are qualified in some science, but have considered that there is recreational value in another field of study, in which, perhaps, their own special knowledge could make a novel contribution. Finally, there is that large body of people who, while not likely to write scientific papers, have a great interest in the lives of animals, and can contribute very important data for the use of others. Chapter 8 is almost entirely built on their labours. I have not attempted to separate these classes, for they overlap, and some of the things I shall say might interest any of them.

I begin by commending to notice the comments of Andrewartha and Birch (I954) on pp. Io and I I, paragraph (c), and elsewhere in their book, in which they stress the need for statistics in ecology, and criticize what they consider the misuse of other forms of mathematics. As an ecologist, I think with them that it is my task to find out what actually does happen: not what might happen under certain artificial conditions, or in exceptionally simple natural circumstances. The lives of animals are usually so complicated that we must study as many variables as we can all at the same time. There is no way of doing this except that which the statisticians have pointed out to us, and usually we need more data than we can possibly collect for ourselves. It is therefore remarkable that, as I pointed out in Chapter 8, so little has been done to use the very great amount of information that has been collected together by various organizations such as the Royal Meteorological Society in their Phenological scheme. All I have done is to pick out from the eighty or so animals in that scheme the one that interested me. There is every reason to suppose that the others could be investigated in a similar way, using, no doubt, different variables. Williams (I95I) in a paper that is not itself a phenological research, but 
was written to encourage entomologists to examine these records, much as I am now doing for ecologists at large, has a number of comments and criticisms. Some of these seem to be based on a projected use of limited scope, but others are interesting. I do not think, however, that Williams stresses the most important point, which is that the information that can be extracted far exceeds a mere research into a date of a natural event. Because we keep our records of weather and many other events classified according to date, we have, once we know the date of an event, an almost unlimited amount of information at our disposal. To consider phenology as a mere matter of dates is like considering an index as something to do with the alphabet. For example, take the date of arrival of the cuckoo. Not being an ornithologist, I have no idea how closely this date is correlated with the date at which it is first heard calling, but I should guess that the correlation coefficient must be high. It should therefore be possible to use an immense amount of records to study the factors affecting its arrival. There is little doubt that weather records, classified by dates, could be obtained from France, the Mediterranean, and from Africa, and included in a scheme as in Chapter 8. To point the matter by an absurd example, it would even be possible to include atmospheric pollution in New York, or the height of the tide at Singapore, if the investigator thought that these might show a significant effect. All this could be done now, without lifting a finger to get specially collected data.

There seem to be two main ways in which this could be done. The methods of Chapter 8 could be used by anyone prepared for about two years work on the problem for one animal, after preliminary work had established the main factors involved. It would be unwise to assume the correctness of any accepted hypotheses not verified by adequate statistical analysis, so that there might be a considerable amount of abortive exploration. The alternative is one that I have discussed with Dr. J. F. D. Frazer. Once the records, both phenological and meteorological, were collected in suitable form, electronic computation could immensely shorten the labour required to deal with every animal separately, for, with all the means, totals, variances and covariances, equations such as that in Chapter 8 could be built up rapidly. The result of the application of either method would be an unprecedented amount of information on the external factors affecting salient events in the lives of animals and plants, taken straight from the field, and 
therefore quite free from any doubts about relevance. In the next paragraphs, I compare the advantages and disadvantages of these two suggestions.

The advantage of the single-handed method is that the biologist does not have to seek the co-operation of anyone. The data are all published, and later in this chapter, I give detailed directions about the procedure of getting them. He can work at his own speed, even if this takes years. He would have to be very familiar with the animal or plant he chooses to study, and he would have to know or to learn statistical techniques. Unless he can borrow a calculating machinc, he would need the money from his own resources or from a research grant to buy one, but, apart from this, the cost would be mainly stationery, fares and postages on books. The main drawback is that the patience to sit for hundreds of hours of computation and compilation of data may not be common, but here I would point out that the intricate operations have an interest of their own, and that real flashes of the excitement of discovery will probably appear. Some of the more mechanical operations can be carried out almost automatically: I have often listened to a radio play while doing them. The idea that any biologist likely to contemplate this work would be unable to learn the technique is one that I have often heard, but cannot credit, and I shall discuss this point later in this chapter.

The advantage of the combined effort, electronic computor scheme seems to me to lie mainly in the reduction of some of the drudgery, but also in the great economy resulting in the sharing of the work of collection of the meteorological data among so many items in the list. For example, all the events in May could, as a first approximation, be supposed to be influenced by the same weather factors. Moreover, some of the events would probably turn out to be strongly corrclated with each other, but some would not. This would suggest that those that were correlated shared the same external influences, and this might lead to the discovery of what these were. The drawbacks are: the difficulties of getting co-operation between biologists interested in many different things, and the high cost of computation. I was told that for my little portion alone, although the actual computation would take only five minutes, it would take an expert operator three weeks to transfer the data to the operating tape, if I needed twenty variables at twenty levels each. The cost would have been from $£ 200$ to $f_{300}$. With all the items in the phenological list to do, only one 
of the largest computors would be suitable, and the cost would be far more than this. Work of this kind cannot be merely handed over to the statistician with the request "to get on with it." Only the biologist can tell him what to look for, and what functions to use, and after computation the processed data would have to come back to the biologist to be digested. The compilation of the meteorological data into a form suitable for the computor staff would be a large operation. It took me many months, for there were nearly thirty thousand entries to make, and each came from a closely printed page, out of which only a few items had to be selected. This work could, of course, be delegated, but someone would have to do it-there is no mechanical way.

I am inclined to think that a combination of the two methods might be more practical. If the data could be processed, and the results published or made available to interested people, the biologists would be spared the drudgery, but would be free to work in their own way as in the first scheme.

I suggest that those now in charge of similar schemes of collection of large masses of biological data should not allow the schemes to run on for too long without a statistical review. It is not true that tens of thousands of observations for scores of years are essential for proper conclusions, and great waste of effort can result from the accumulation of far more data than is necessary. It should not be forgotten that in statistics, it often happens that the value of the information only increases as the square root of the number of observations. Merely to double the accuracy of some of the results of Chapter 8 would need a century of more observations. I had enough with twenty-four years, and the main outlines were visible after only six. Moreover, the inclusion in the new schemes, of which there are a number, of the same animals and plants as were included in the Royal Meteorological Society's scheme seems to me a waste of effort. The Meteorological Society's data are so voluminous that surely no one can need any more of the same kind. It is computors that are now needed, not observers or compilers. Of course, these comments do not apply to recordings of animals and plants not in the older scheme for this information will be needed in the future.

As this book was being written, a letter to Nature appeared (Gunn and Symmons, 1959) on the subject of forecasting locust plagues. It bears out some of the remarks in this chapter so well that it seems 
useful to make some comments upon it. The authors have found that by using the total rainfall of the previous season as one independent variable in a multiple regression equation, and the density of the parental population as the other independent variable, a multiple correlation coefficient as high as 0.89 was obtained. It is now possible in this area to make a prediction of a locust outbreak with high accuracy as soon as the July records are available, even though the outbreak will not occur until the following year. The economic value of this work needs no words of mine to emphasize, and I confine inyself to the principles that are of equal scientific importance, whether they are applied to frogs, cuckoos or to locusts.

On p. I93 I point out that the criticisms sometimes advanced against the use of measurements of weather from distant weather stations-that the weather there is not that at the point where the animals live-is based on a misconception about the nature of the statistical approach. This does not require absolute accuracy and we can get along very well with less than perfect data, if we cannot have just what we would like. Now, Gunn and Symmons did not even use rain gauges-they used the height of a river to indicate approximately the amount of rain in the river basin. The next point to note is that the records they used extended over only ten years, which supports my suggestion that valuable information can come from quite short series of observations, if only the right methods of analysis are used. It was a hypothesis directly obtained from the field, followed by correct analytical methods that led to success. There were no vast masses of undigested data, and no conjectural mathematical models.

Gunn and Symmons have, of course, had some good fortune in finding that only two independent factors give them the accuracy they need. As they themselves point out, other species may not prove so simple. These might yield to the methods of this chapter or of Chapter 8.

A few historical comments may be of interest. So far as I know, the first use of multiple regression analysis to predict the date of an event in the life of an animal was in my paper of 1935. Davidson and Andrewartha (1948) used a similar technique in their study of population fluctuations in an insect. Williams (195I) proposed the use of the analysis of variance in the study of phenological data, but did not use it for this purpose. Moran (1953), studying the Canadian Lynx cycle, stated that multiple regression analysis would give the answer, 
but that it was too laborious. Perusal of these papers suggests that in each case, the authors have arrived at their conclusions independently, for none of the authors I have just cited refers to the work of the others, although all are in fact mutually relevant.

I have alluded above to the idea, frequently held, that statistics is a subject that is difficult and beyond the grasp of many people. I believe that there must almost always be something wrong in this idea. To begin with, statistical tests differ enormously in their difficulty. The very important chi-squared test in a $2 \times 2$ table is so simple that a child can do it. What must be distinguished is the difference between the difficult, the intricate and the laborious. Few statistical operations require elaborate mathematics: most need only simple arithmetic. There is sometimes difficulty in focusing the concepts so as to make a choice of the appropriate method, particularly in the analysis of variance. Some operations are intricate, but not difficult. For example, the solution of the simultaneous equations that led to the equation in Chapter 8 by the Doolittle method required four sheets of mathematical paper pasted together, so that all the intricate workings could be put on one sheet. But all these workings were simple arithmetic, and this part of the operation did not take many hours. On the other hand, the correlation tables from which the variances and covariances needed for this operation took many months to complete. This work was very laborious, fairly intricate, but quite easy. The next error that I suggest may be found is that a statistical operation is thought of as similar to the calculations that come at the end of a day's research, when a few percentages summarize the results. In fact, an elaborate statistical operation is the research itself, and may take months or years. Disappointment is bound to follow if this is not realized, but the time needed does not make it difficult but only laborious.

\section{Statistical Books}

This subject is so important that it deserves a paragraph to itself.

Being myself a poor mathematician, I think I know a difficulty experienced by those who resemble me in this respect. They have not found the right books. I find that one statistical topic is most easily understood from a book by author A, but another is, for me, better explained by author B. It is quite possible that with two other topics, the position of the two authors would be reversed, and other people 
might very well not agree with my selection. I habitually use at least four statistical books for this reason, and my advice is that if difficulty is experienced with one book, another should be consulted. I cannot easily understand a new statistical topic by reading about it in an armchair. Not until I sit down with paper, pencil and calculating machine can I really see what the author is trying to tell me.

For the ecologist, a book or books on general statistics will be required. There is now a considerable number of these. Ecology is a very practical science, and the best books for the purpose are probably those with an industrial outlook, for the irregular data that must often be used are most likely to be treated in such books, and may not be adequately considered in books intended for the laboratory experimenter. For this reason, books that lay excessive emphasis on the analysis of variance may not be useful, for this excellent method is an experimenter's tool. It requires a high degrec of symmetry, and if there are serious gaps in the record, it cannot be applied at all. In the spawn date investigation, for example, observers entered and left the scheme all through its existence, no two areas were equally represented, no two years had the same number of observations. Correlation analysis is unaffected by these features, but the analysis of variance cannot be applied to data in tatters. Williams in suggesting that the analysis of variance could be applied was perhaps misled by the apparent symmetry of the published summaries. These looked temptingly like data suitable for this technique, but the illusion does not survive closer acquaintance. After what I have written about the necessity of individual choice of a general book, it is of course absurd to make too strong recommendations, but I would suggest that Davies (1949) and Brownlee (1949) should be tried. Fisher (1932), the first book to be written for research workers, is often thought to be difficult, but, in fact, it is sometimes easy to find the right method there. In six months or less, any person likely to need those methods should be able to apply them by following these books. I personally make no attempt to remember the details, but, unless the method is one I often use, I work with the books open beside me. Intricate details need not be memorized as if for an examination.

No general book on statistics known to me contains an adequate account of correlation analysis. Most do have a chapter or two on the subject, but that is not enough, and the methods thus briefly explained are too simple for ecology. The book by Ezekiel (1930) is probably the 
only one that is sufficient, a belief that seems to be supported by the fact that two authors of general books, Tippett (I952) and Kendall (I952), both refer their readers to Ezekiel after giving their own short treatment. Ezekiel's book is quite a large one, and is a special text dealing only with this subject, but it is lucidly written, and easy to use.

\section{Some Examples of the Application of Statistical Methods}

This section and the Appendixes are intended to serve a double function. The statistical evidence for many of the statements in the preceding chapters is here set out, and serves also to illustrate the methods.

In many parts of the book there are examples of the simple $2 \times 2$ tables. All that has to be done to the data is to arrange it in the form of a table in which all the four possible combinations of the two factors are represented. If it is not at once obvious what classification to adopt it may be necessary to make an arbitrary decision. For example, in Appendix I, (c) (on p. 205 below) I had to decide for the purpose of one of these tables what was to be regarded as a warm day. I chose $10^{\circ} \mathrm{C}$ as the dividing line between a warm day and a cool one. I might have chosen some other temperature and, in fact, I did try other levels. I then counted the occasions above $10^{\circ}$ and below, and the number of records of spawning that fell into these two classifications. This gave the actual numbers in each class. Now, if there had been no connexion between spawning and temperature at this level, these classes should be in proportion. To find the expected number on this hypothesis, all that has to be done is to divide the total number of observations by one of the marginal totals, say that in the bottom left-hand corner, and multiply by another, say that in the top right-hand corner, and one obtains the expected number for the class in the top left-hand cell of the table. This is then written down in brackets. The other expected numbers follow by subtraction, for the totals of the expected numbers must agree with the actual numbers. Sometimes it is so obvious that the results are merely those that can be ascribed to chance, because the actual and the expected numbers agree so closely, that it is really superfluous to go on, and there are conclusions in the literature that would hardly have been published if the authors had even constructed such a table, let alone worked it out as in the next few sentences. The next step is to subtract each of the expected numbers from the corresponding actual numbers, and square the results. Each square is then divided by the expected number, and the results added. This number 
is $\chi^{2}$. If it is 3.8 or under, and particularly if it is under $2 \cdot 7$, there is no good reason for supposing that the results are anything but chance. If $\chi^{2}$ lies between these two numbers, it may be worth considering whether to collect more data to make matters more certain. If, on the other hand, $\chi^{2}$ is over $3 \cdot 8$, and especially if it is over $6 \cdot 7$, the actual results cannot fairly be ascribed to chance. This would be equivalent to very strong evidence for the view that temperature does affect spawning.

I have purposely left out two minor precautions. The numbers expected in any cell ought not to be less than five: otherwise there is really not enough data, although the information can nevertheless be useful, for any guidance is sometimes better than none. If the numbers are rather small, it is better to subtract 0.5 from the "expected" number if this is larger than the actual number and add 0.5 if it is smaller. If the numbers are all large, it does not matter much whether this correction is applied or not. Now there is surely no one likely to be reading this who could admit to inability to do this kind of arithmetic. If he can do it, then he can "do statistics" and can prevent himself reaching conclusions that have no sound basis, or, what is just as important, failing to see connexions between events that are in the data. The chi-squared test can be used to compare any series of numbers expected on some hypothesis with those actually found, and more complicated examples can be found in the books, or even in this one. For simple examples of the test, see Appendixes $I c, I d$, and $I h$.

A more elaborate example is to be found in Appendix $\mathrm{I} b$ in which the number of parasites found is compared with those expected on the hypothesis that the infestation occurs purely by chance encounters between parasite and host, swimming in the same pond. The work of the statisticians has given the proportions expected in such a case, and it was found that the actual results cannot be reconciled with this hypothesis. In Table 6, the total number of frogs killed during migration has been distributed in proportion to the frequency of the winds from various directions. If migration had been random, the last two columns should have agreed. But they did not, and a calculation of $\psi^{2}$ shows that there is no reasonable chance that the disagreement is an accident. Migration is definitely related to wind direction.

\section{Analysis of Variance}

This more elaborate test has so many variations that it cannot be described here in detail. Appendix $\mathrm{s} a$ is an example applied to size 
variations in colonies of tadpoles, and shows that the different colonies really did differ by far more than could reasonably be ascribed to chance. Unfortunately the analysis of variance has a rather limited value in ecology. This is because it so frequently happens that the data are not sufficiently symmetrical for the method to be used. Even if one tries to collect data in a symmetrical form, the efforts are often frustrated by gaps in the records. It may be very tiresome if a farmer fills in a pond half way through our investigation, and so destroys a set of observations carefully designed according to all the best books, but we cannot stop him. Nor can we order droughts and snowstorms just when we need them. We must use methods that are not so sensitive to irregularities, even if we lose information and have to expend more labour.

\section{Correlation Analysis}

This is a most important ecological method, for it fulfils the need just mentioned. Provided that numerical data exists in corresponding pairs or larger groups, correlation analysis can be used even if the data is fragmentary. Moreover, both graphical and mathematical methods can be used. Chapter 8 is really one long example of what can be done with this statistical tool.

\section{The Statistical Methods of Chapter 8}

Ezekiel's methods have, so far as I know, not been applied to an ecological problem such as that of Chapter 8 and it may therefore be of interest to give here a short account of the procedure adopted in working up the Phenological Reports, especially as the full investigation has not been published anywhere else.

The Phenological Report was an annual publication of the Royal Meteorological Society. In the early years of the frog-spawn records these dates were not fully included in the annual report, and in the I935 work I had to extract the details from the observer's original returns. In later years, the Report itself contained the necessary details. I was fortunate in having the help of Dr. Frazer to copy out the data and supply the whole of it in an easily usable form. For each spawn record seven meteorological readings were actually used, and some more were collected but were not thought important enough to use. These records came from the Monthly Weather Report of the Meteorological Office. As attendance there to extract the data would 
have been for me a practical impossibility I obtained permission to borrow the volumes in sets as I needed them. All this mass of data, both for the spawn dates and for the other variables, was transferred to punched cards. In the case of the meteorological data I wrote hardly anything, but found the necessary item on the page, and clipped the cards according to the code. Various codes were used according to the circumstances. I adopted I, 2, 4, 8, as the numbers of the holes needed in combination to add up to I 5 , in preference to the more usual I, 2, 4, 7, because although this code never needs more than three clippings to register the number, they only add up to 14 . To give an example, I used Fahrenheit temperatures because the Centigrade scale is too coarse a grouping, and to use a decimal would have taken another hole. I ignored decimals of a degree, and subtracted 30 from each reading. A temperature of $37^{\circ} 4$ thus became 7 on the cards, and was registered by punching holes $\mathrm{I}, 2$, and 4 . All these adjustments can be done mentally, at the moment of punching. There are some temperatures under 30 and over 45 . To have dealt with these relatively few readings by the code would have needed morc holes, so I punched all the holes, which acted as a warning to look for the actual number, which I wrote on the cards. It is unwise to be too slavish in this matter of punching-it may be simpler to write some of the data. For example, I needed the mean spawn date on many occasions. To use the holes to find the date on each card would have taken too long, so I wrote the date as well as punching it.

Having prepared the 2,734 cards, the next step was to set up the correlation tables. This was done by first taking the cards, and sorting according to one variable by needle. This is a well-known procedure, and consists in passing the needle through the " 8 " hole of a bundle of cards, as large as can be conveniently handled, say roo cards. The cards with this hole clipped fall, the others remain on the needle. Each of these piles is then sorted by putting the needle through hole " 4 ," and so on until all the cards have been sorted into piles, each corresponding to one temperature. These piles were then secured by a tie through a large hole near one corner of the cards, and put into a tray. Each bundle was then taken and sorted in a similar way according to the second variable. The cards in these much smaller bundles were then counted and the number entered in the appropriate space in the table. The small bundles were combined and replaced in the tray, for the next table will require one of the variables to be the same, if the 
work is properly planned. Each table therefore needs only one sorting, except when the combinations have been exhausted, and a new variable is required. For example, if all the temperature combinations have been found, and the last one has rainfall as the second variable, the cards have only to be bundled according to rainfall for the process to start again for all the rainfall combinations, without the need to sort specially for rainfall. The sorting usually took about three hours. In order to avoid the monotony of too much unrelieved sorting or of computation, I always computed the tables as they were completed. Computation usually took about the same time.

If one is doing a short computation needing a few hours, it is reasonable to require a check of the exact number of the cards by a re-count, and to require check sums and products to agree exactly. On this scale, however, weeks or perhaps months of extra work would have been needed to do this. I therefore tested by experiment to see what effects small errors would have, and concluded that the larger bundles of cards need not be counted twice, for any likely error could not affect the final result. The smaller bundles were checked, but of course this did not take long. A serious error would show, and was followed up. In a similar way, although the check sums and products often agreed exactly, and I never omitted the precaution of computing them, I did not re-compute for errors in the units or tens columns, for these did not affect correlation coefficients computed to two decimal places. Care is needed in planning on these and similar points, for it would be easy to spend weeks in wearily re-computing statistics already quite accurate enough.

It is quite interesting to watch these tables growing under one's pencil. Before the actual computation has even begun, it is often possible to get a fair idea of the size of the correlation coefficient that will emerge some hours later, merely by looking at the way the figures lie on the paper, and there is some satisfaction in finding at the end that a guessed "o. 4 " turns out to be " 0.36 ."

In the end, all the possible combinations have been tabled and computed, and all that is now needed is to put the variances and covariances into a series of simultaneous equations and solve. This can be done by eliminating one variable at a time, as taught in schools, but on this scale it is better to use the Doolittle method. This is described in detail in Ezekiel and also in Brownlee (1949). It is too long and intricate to describe here. It requires rigid attention at first, 
but with practice, it is not difficult. The final result is that the coefficients of the equation are obtained, and the result of months of work can be written in one line.

\section{Joint Functional Regression Diagrams}

These require the variables to be sorted in three ways, first according to the two independent variables, as just described, and then the mean spawn date for each bundle has to be found. The analytical processes are illustrated in Figs. 47. The data are taken from the joint functional regression diagram for $\mathrm{MI}$ (Fig. 36). In order to reduce the space needed for a full reproduction of the processes involved in constructing the diagram, only the data from $32^{\circ} \mathrm{F}$ to $38^{\circ} \mathrm{F}$ and from 0 to $70 \mathrm{~mm}$ of rainfall are used. This has required only 22 curves, instead of the 72 much larger ones in the actual investigation, but they are sufficient for the explanation. The removal of part of the data has naturally altered some of the details, and Fig. $47 d$ is therefore not quite the same as the corresponding part of Fig. 36. In Fig. $47 a$ the original data are indicated by dots, each one of which is the mean of all the records with the corresponding co-ordinates. It happens that these means were all derived from more than ten records, but, if any mean had been based on less than ten, the actual number would have been written alongside the point as a guide to the weight to be attached to it when drawing the line. Through these dots, a line has been drawn free-hand, lying as evenly as possible among them, as far as can be judged by cye. In $47 b$ is shown a series of graphs at IO-mm intervals of rainfall, in which each point shown has been read from the curves in (a). For example, the point on the $45-\mathrm{mm}$ curve at $34^{\circ} \mathrm{F}$ in $47 \mathrm{~b}$ is exactly at 70 days, and it can be seen from the curve of $34^{\circ} \mathrm{F}$ in 47 a that the curve cuts the 70-day line at $45 \mathrm{~mm}$. In $47 \mathrm{c}$ a similar operation has been performed using the curves of $47 b$ as data, plotting against rainfall as abscissae. These curves therefore reproduce those of $47 a$, but have been smoothed and adjusted by taking account not only of the points along each line, but according to the neighbouring lines as well. As can be seen, the irregularitics of 47 a have been removed, and the whole series appears as a regular family of curves, changing in form gradually from curve to curve. Fig. $47 d$ is a synthesis of all the curves in $47 \mathrm{c}$, produced by selecting the dates $60-80$ in 5 -day intervals, and finding the temperature and rainfall that correspond. These coordinates are plotted and the points joined to form the isophenes. 

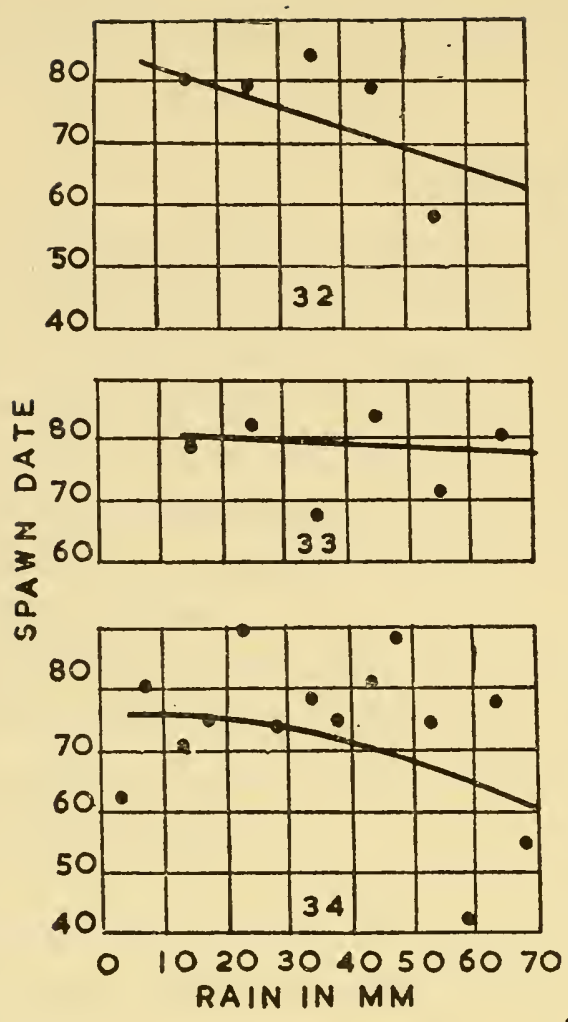
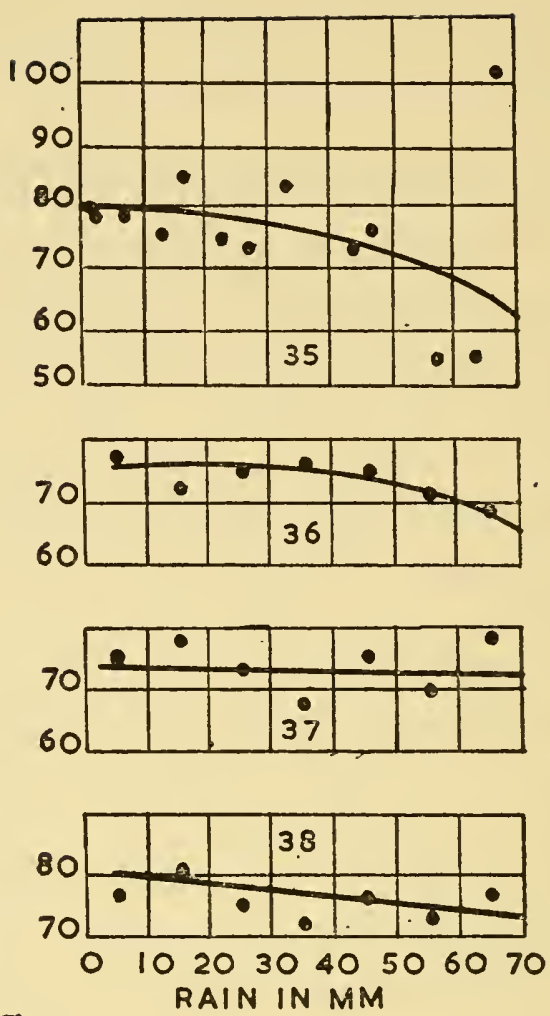

FIG. 47. Examples of the Method Used in Constructing the Joint Functional Regression Diagrams

(a) The original data. For each of the temperatures shown on the graphs, the mean spawn date for all the records at these temperatures has been plotted against the rainfall. Lincs have been drawn freehand to lie as evenly as possible among the points

(b) For each Io $\mathrm{mm}$ of rainfall, as indicated on the graphs, points have been plotted against each degree, as found from graph (a).

(c) For each degree, as indicated on the graphs, points have been plotted against each $10 \mathrm{~mm}$ of rainfall, as found from graph $(b)$. The result is a smoothed version of (a), in which the shape of the curves has been modified by taking account, not only of the points along each line, but of the shape of neighbouring lines as well. Note the reduction of the scatter, and the appearance of a consistent family of lines.

(d) The final joint functional regression diagram. Using graph $(c)$, the coordinates, rainfall and temperature, for each year day, at five day intervals from 60 to 80 , have been found. The plotted points have been joined and form the isophenes. 

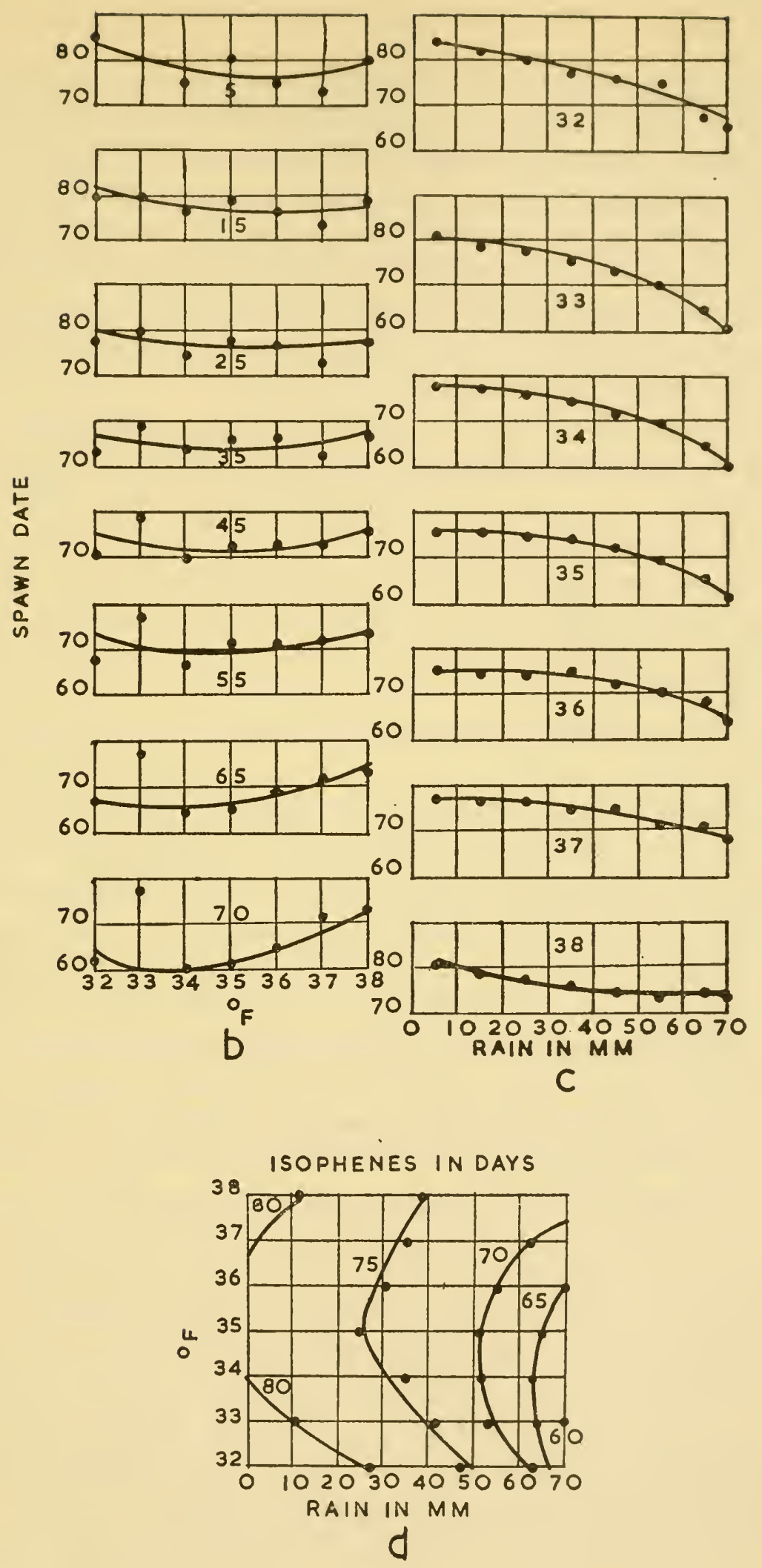
These processes may sound difficult, but this is not so. They are intricate. One advantage, as pointed out by Ezekiel, is that the investigator is forced into contact with his data. If research workers pass on their data to others to compute, it is quite likely that the computor will miss seeing something that the research worker would have noticed if he had actually handled the data over and over again, because, of course, statisticians cannot also be experts in every science. When they write books "for research workers" that is just what they mean, and they should be taken at their word.

I have not followed Ezekiel exactly, for, when the variables are as closely spaced as mine, for example at intervals of single degrees, it is not necessary to strike numerical averages as he does. The whole process can be graphical.

It is sometimes thought that mathematical equations are more objective than graphs drawn free-hand. This is not always so, particularly when the data refer to some complicated system. The error lies in a failure to realize that the subjective element enters into the two methods at different stages. The first act in running a mathematical correlation analysis is to decide on a simple function that fits reasonably well. It is very difficult to deal with complicated functions, and, in fact, the investigator usually tries his utmost to find a function that converts the curves on his first chart into straight lines. For example, in the biological assays of drugs, statisticians have provided highly objective tests for assays on which human life often depends, but the processes by which these assays have been made to conform to the essential requirement of linearity might very well shock those who believe that a mathematical equation somehow expresses natural facts with an almost supernatural exactness. What actually happens is that the biochemist explores conditions in the laboratory and on his desk until he finds a limited range of concentrations and other variables within which the relation between concentration and effect can be expressed well enough by a straight line when the variables have been converted into logarithms or reciprocals or some other functions. He never expects that the line will be straight at all concentrations, and does not believe that it expresses anything fundamental. It is a working device of great practical value in comparing Preparation A with Preparation B. Once he has found out how "to straighten the line" the mathematical processes are completely objective.

On the other hand, in ecology we are usually not concerned with 
such comparisons. What we want to know is the nature of the function that really does describe the events, and we do not mind if it looks like a corkscrew when it is plotted. Our graphs are therefore frec from any subjective bias at this point-we draw what the data tell us to draw. There is, however, some judgment involved in drawing curves free-hand, but far less than is usually realized. This is especially true of these representations of surfaces, the joint functional diagrams, for it is very difficult to draw a family of lines through a succession of independent points in more than one way by following Ezckicl's methods. Ezekiel suggests that the choice between a graphical or a mathematical method should depend on whether there is a logical basis for expecting a mathematical function to fit, as there often is in simple physics. If there is no such basis he thinks that graphical methods should be used. It is surely very rare in ecology that we can expect that any simple mathematical function could represent the immense complexity of nature, and with Andrewartha and Birch, I doubt the value of attempts to use deductive mathematics as models for natural events. Statistics is quite another thing: it is a tool for investigating what really does happen.

It is sometimes thought that in an investigation of this kind, in which the weather records come from stations perhaps thirty miles or more from the place where spawning took place, and therefore cannot be quite right, the conclusions may be falsified and give rise to correlations that are inaccurate. The true position is that random errors in the independent variables lower the correlation below that which would exist if the right values had been used, but leave the regression unaltered. The danger that exists is thus not that the correlation will be falscly high, but the reverse. Correlations already much higher than the level of significance will be still significant but very low correlations may slip down into the non-significant group, and escape notice. These low correlations are ignored here anyway, so that there is nothing to fear. Random errors in the dependent variable may lower the regression seriously, but the danger here is similar: regressions that really exist but are small may be missed, but false ones are most unlikely to be created. The position may be more complicated than this summary, and Ezekiel should be consulted.

A similar mistake is made when it is supposed that the use of approximations such as air temperatures instead of water temperatures, which are almost certainly the true factors, could produce false results. Mean 
air temperature is closely correlated with mean water temperature and the effect of the approximation is to lower the correlation, not to raise it. Of course, we ought to use the best measures available, but if there are no water temperatures on record, we can make shift with what we can get, confident that if we had the better measure, our conclusions would be even more certain, and very unlikely to create a relation where none exists.

The number of degrees of freedom in this work is doubtful. It is certainly not as high as 2,734 , the number of variables in the multiple regression equation, if only because the number of meteorological stations was less than the number of phenological stations, so that the weather records were used for several observations in the same year. Moreover, weather records from widely separated parts of the country are almost independent, but those from adjacent areas are certainly not. This difficulty has been evaded by the scale of values in Table 8. A correlation coefficient of 0.2 is significant with only Ioo pairs of variates, and there are certainly far more degrees of freedom than that. In fact, in such a large scheme, questions of statistical significance play a far less important part than in the small scale experiments and observations usually encountered.

It has sometimes been pointed out that multiple regression equations are never complete, because we have no means of knowing when we have included all relevant factors, and if, as usually happens, there are correlations between all of them, we can never know that our coefficients are correct. There is, philosophically, no doubt about all this, but there are three practical points, one mathematical and the others logical, that are insufficiently stressed in the argument. It is probably rather rare for the ecology of an animal to be dominated by one factor or a very few. These are the easy cases to recognize, and our present knowledge is probably overweighted, so that the numerous cases in which multiple causation is at work have not been understood. Now, whenever a number of roughly equal causes are operating, the individual partial correlation coefficients must be weak, even if together they provide a complete description. Weak coefficients have little influence on each other, as can be seen from the following formula for calculating a partial correlation coefficient from three simple ones-

$$
r_{12 \cdot 3}=\frac{r_{12}-r_{13} r_{23}}{\sqrt{\left(\mathrm{I}-r_{13}{ }^{2}\right)\left(\mathrm{I}-r_{23}{ }^{2}\right)}}
$$


It can be seen that the original simple coefficient, $r_{12}$, is corrected by subtracting the product of two small numbers, $r_{13}$ and $r_{23}$, which must be very small, and then dividing by a number that cannot be far from unity. It is therefore not much altered by the operation, and in fact the important coefficients in the spawn investigation showed themselves to be so right from the beginning. The reservations about multiple correlation have much less force in this field than when some of the simple coefficients are large.

The logical points are also important. A research worker ought not to expect that any single factor should appear very important, and must not be upset by criticism that since the correlation he has found is low, he has not succeeded in finding what he was looking for. Of course he has not-there is no large key, but only a number of small ones, one of which he has found. It is also a fallacy to suppose that it is a failure not to identify exactly the operating cause of an observed correlation. If two variates can be shown to be correlated, it does not at all follow that one is acting directly on the other, so that it can be called a cause. It may merely be highly correlated with another factor that is so acting. But the discovery is a great scientific advance, for we have limited the field of search to a defined area. We must look for factors correlated with those indicated by the mathematics-nothing else is likely to be useful.

In certain critical parts of the joint functional diagrams, such as the region of the minimum at $0^{\circ} \mathrm{C}$, there were not very many records, so that tests of significance were applied. This was simply done by taking the results contributing to the minimum point and testing by the computation of $t$ whether this mean differed from that of the two peaks on each side. In this case there was no doubt about the significance.

In the I935 paper, I pointed out that observers might very well be late, but were unlikely to be early, so that a biased error was to be expected. Williams (I95I) came to a similar conclusion, but drew the further inference that the distribution of phenological dates could not be normal, and should have the attention of research statisticians. The distribution of these dates is not normal when tested by the computation of the third and fourth moments (Fisher, 1932) but is negatively skewed and sharply peaked, both conclusions being statistically significant. The negative skewness is contrary to the expectation of Williams and myself. It cannot surely be that observers never make 
mistakes: it must be that the mistakes they make are too small to matter, and have been impotent to alter seriously what is probably a shape of curve characteristic of the phenomenon.

\section{Trends}

A considerable amount of time was spent in investigating trends, but no evidence of any disturbance to the conclusions was found. One of particular interest concerned the possible effect on spawning of the changes in agriculture due to the war in 1939. Ditches were cleared, and an agricultural revolution took place that might well have affected animals on the farms. There was no significant effect whatever.

\section{The Variety of Techniques}

Elton (I927) in his pioneer book on ecology has mentioned the need for an ecologist to use the techniques of a number of branches of science. Ecology may, in fact, require almost any branch of knowledge, and is no subject for a person who is not prepared to learn new techniques as often as is necessary. It is unreasonable to expect much help from others. Every scientist has his own work to do, and it is only by a lucky chance that one may be found who is willing to collaborate, unless both are working in the same organization, where a coordinated approach is natural. Advice that does not take much time is usually freely given, but, in spite of frequent complaints that scientific education is too narrow, there are surely few scientists who cannot teach themselves most of what they need from books and by practice. There is a great difference between the range of chemical knowledge required by a chemist, and the limited chemical techniques needed, for example, to analyse water for calcium. In industry, junior technicians carry out intricate analyses accurately, but they cannot usually originate methods. I have had no formal botanical training, but from books written by botanists I have learnt to recognize under the microscope many of the common algal genera at least.

\section{Choice of Subject}

This must always be personal, because unless interest is there, success is unlikely, and there is no subject that interests like the one we find for ourselves. The gaps in this book may suggest suitable subjects to anyone, but many of the methods used could be applied to other animals, and of these, there is an unlimited number. It is not necessary 
to go on an expedition to some remote part of the world. I have often looked at the gratings round the roots of trees in London strects, and wondered what kinds of animals live there, how they differ from other tree-root communities elsewhere and from each other in the same strect, how colonization began, what changes of fortune affect them, and why. Choose a subject that is near at hand, for you will not live long enough to make a thorough study of your animal if you have to travel far mercly to see it.

For those with no scientific training, there is still a grcat amount of simple observation that could be of scientific importance, for animals are watched in their natural environment by very few people who are also willing to write about what they see. But the observer should also be willing to acquaint himself with the literature on the same subject, and should read the observations on literature in a later section. Tinbergen (1953) has suggested that one animal is enough for one person. I have much sympathy with this point of view, but perhaps an occasional excursion into some other field is advisable to broaden the outlook.

I believe that the animals being studied should reccive as little interference as possible, for as soon as one does anything to them, they are no longer "at home." By all means use any laboratory methods to study the environment, but leave the animals themselves alone. In my tadpole work, I decided in advance that my sample need not exceed ten tadpoles from each pond each week. This small number was no more than one additional dragon-fly larva could destroy, so that I could hardly be upsetting the facts I was studying by more than a trifling addition to the hazards already present in the pond. I would have preferred not to collect at all, but I could not get my information in any other way. Knowing what I wanted, there was a temptation when walking up to a pond to start collecting at once. I resisted this, and deliberately spent the first period at the pond merely looking into it, so that I came to know what the animals did before my net touched the water. Elton has some useful advice and should be consulted.

\section{Pond-finding}

Some areas contain so many ponds that it is easy to find them. But the ponds thus found may not be the right sort of pond. Other areas have few ponds. Ponds may lie unsuspected in a hollow in a ficld that is familiar in another corner, and much time can be lost in searching. 
The best method I know is to get a six-inch Ordnance map of the area. The surveyors rarely missed the smallest pond, and with the map one can leave the road and walk straight to the pond. Abroad, ask the local inhabitants.

\section{Literature}

The use of scientific literature forms a part of the basic training of a scientist. Those people without scientific training, or those who have not themselves carried out any original work in science do not usually know the steps necessary in order to find out what has been done before in that particular line of study.

The addition of new knowledge to science is not properly done without this process of finding out, for the building of science is not constructed by anyone who chooses to throw a brick on to a heap, but by laying it with the intention of contributing to the whole edifice. A book may be a useful start to this work, but the main object of books is to stimulate thought, and for the detailed records it is usually necessary to go to the original source in a scientific journal. For every science, there is some form of annual publication in which at least the titles of papers are listed, and in many there are abstracts as well. By consulting these, a list of apparently relevant publications is built up. The next step is to see and make extracts from these papers. All this work has to be done with the aid of a scientific library. It is hardly possible to get very far in zoology without the library of the Zoological Society of London, and it is therefore practically essential to join the society. The quickest way of using any library is to attend in person, but, once the journal is known, it can be sent by post. It should, however, be remembered that it is rarely necessary to read the whole of a scientific paper thoroughly, and many consulted will turn out to be useless for your purpose. In a short time at the library, it is therefore possible to get the main facts you need from quite a number of papers, and, if there is one that needs more detailed study, it can be borrowed.

It is not necessary to know a foreign language well in order to understand a foreign paper. Many of the technical terms will be found to be nearly the same, and what is wanted is not a literary translation but the sense of it. The World List of Scientific Periodicals shows for each journal, English or foreign, where in the British Isles any particular journal is to be found. It is just possible that there is another library 
other than that of the Zoological Society that has the book, and, since the ecologist must be continually working in other sciences, it will often happen that he must use other libraries. The occasional use of private libraries is not usually difficult, but it should be borne in mind that the library of a scientific socicty is one of the main reasons for its existence and absorbs a large proportion of the subscriptions of its members. It is unreasonable to expect that facilitics will be afforded to outsiders for an indefinite period. Any access on one or two occasions is a privilege that must not be abused and indeed may not be granted at all in some libraries.

There are a few libraries open to the public. The British Museum Library is onc. Access is by ticket from the Director, but, once he has been satisfied that there is a serious reason for the use of the library, there is no other qualification. The Science Muscum also has a uscful library. The drawback of both these libraries is that the worker does not have access to the shelves, but must depend on the attendants to bring requisitioned books to the reader's place. This takes much longer than finding them for oneself. It is, however, possible to requisition books in advance by post, if one knows the catalogue references, and the books will then be ready to read at once. The Meteorological Office Library is available to readers and borrowers who satisfy the Director that they are proper persons to be allowed these facilities, and the books can be sent by post. The proper use of libraries is an art, only to be acquired by practice and perseverance, but it is remarkable how quickly a piece of information can be found by using the right methods. The bibliographies at the ends of papers provide short cuts, for in them the author lists the papers he has found useful, and so the process branches out, each paper giving a new set of clues.

One advantage of specializing in one animal is that, once the early work has been found, much of the later searching can be confined to going through the yearly part of the Zoological Record, and following up the recent publications, although it is usually necessary to keep a watch on other relevant topics. A completely new topic may take months of searching before its background becomes familiar. It must not be thought that all this work is drudgery. On the contrary, it is interesting to see what other people have done on one's own subject, or on one related to it. It often happens that on turning over the pages of a journal to find the papers one wants, others attract attention, and may throw unexpected light on the subject. 
Papers still appear in which the author has apparently not bothered to look at anything but the most recent literature of his own country. They can often be detected by the range of dates in the bibliography and by the national bias in the choice of journals, but this may not always be quite fair. An author may be discussing a very limited topic, in which the only important information is what he has just discovered, or he may be taking it for granted that the previous work will be perfectly well known to his readers, but, on the whole, a one-country, one-decade bibliography is not a sign of good quality. Zoology was well established in the eighteenth century, and, in fact, in life history studies this literature may be more important than that of the nineteenth, when biologists worked mainly on dead animals in laboratories. It is not an accident that of the three observations on spawning given in Chapter 9, none was in the nineteenth century for in this as in many other matters, the eighteenth and twentieth centuries have much in common, and are both unlike the nineteenth.

\section{Publishing Observations}

A person who has made observations that are original has a duty to publish them. Books and a few scientific journals are published as commercial enterprises, but most original scientific work is published as papers in journals at the expense of a society which derives its income from the subscriptions of its members, often the same persons who contribute the papers. In a roundabout way, therefore, scientists pay for the publication of their own work. The quantity of scientific work now coming forward and the shortage of funds for publication has, in my heterodox opinion, given so much power into the hands of referees, editors and publication committees that there is a danger that the reciprocal duty-to facilitate publication-is not always performed. An author, however junior, is someone who has found something. He may not have done the work very well, and his paper may need alteration to make it presentable, but the order of scientific importance is: (I) Author, (2) Reader, (3) Editor and Referee, the servants of the others. It is as difficult to judge the importance of a scientific paper when first published as it is to judge a new work of art, and it is a presumption for anyone to stand in the way of a scientific author and his readers. This difficulty is not new. For example, there were three simultaneous discoveries of the Periodic Law, in which it was shown that the properties of the elements varied regularly with 
their atomic weight. Mendeleef was the first to publish, but Newlands had independently arrived at the same conclusions. At the meeting at which he read his paper, a critic rose to inquire sarcastically whether Mr. Newlands had thought of arranging the elements in alphabetical order. If this man had been a referee under modern conditions, would Newlands's paper have been published?

I therefore suggest that any person who has really taken the trouble to make observations or experiments, and fecls certain after reading the relevant literature that he has something new, should write up the results, submit them for publication, and brave the referees. You, the author, always know more than they do, otherwise it would be they who would have written the paper.

There is, however, a gap in the means provided for scientific publication. A trivial observation may not seem worth publishing. It may be far too small to make a subject for a paper, and even too small for a letter to Nature. If, however, there were many observations all of the same kind it would be realized that the observation was no accident, but a real natural phenomenon. In writing this book, I have often wished that there had been a central register where I could find, on standard postcards, casual but authentic trifling observations on the life of a frog. For example, one observation that frog-spawn had been found in Norfolk in August could be considered a freak event. If, however, in thirty years, there had been seventeen observations, all in the Eastern Counties, it would have started a train of thought that might have led-who knows where? Sometimes authors succeed in inserting minor observations in the midst of other matter. For example, the account of aquatic insects in the food of hibernating frogs appears in the almost verbatim reports of the proceedings of a symposium on endocrinology. It was quite out of context there, and I only found it because I happened to be reading the proceedings. The author and the editor had been wise enough to allow an irrelevant observation to stand in the final printed page, thus enabling me, by luck, to lift it into a place where those concerned with the feeding habits of the frog, but not with endocrinology, may hope to find it.

\section{The Technique of Keeping Animals in Captivity}

The skill often shown by the amateur pet-keeper is probably not easily communicated to anyone else, and in this respect resembles that of the gardener. It is nevertheless true that there is a reservoir of 
knowledge there that can be of much scientific importance. For example, I know that some work on newts by a most competent scientist was held up for a time because the technique of keeping the animals in health was incredibly faulty. The late L. A. Lantz, who had great skill in keeping these animals, supplied the information. Then again, important medical work on schistosomiasis was delayed because the snails which are the vector of the disease did not live well in laboratory vessels. The problem was solved by the application of the technique of the balanced aquarium, with a mud slope at one end. This was a device that anyone with a pet-keeper's knowledge would have applied from the beginning.

If animals show signs that they are living normal lives in captivity, such as by coming into breeding condition spontaneously year after year, I think that observations on them can be quite relevant to what happens in the field. It is therefore well worth while studying what pet-keepers do, and if possible persuading them to write accounts of their technique.

\section{REFERENCES}

Andrewartha, H. G. and Birch, L. (1954) The Distribution and Abundance of Animals (University of Chicago Press).

BrownLeE, K. A. (1949) Industrial Experimentation (H.M. Stationery Office, London).

Davidson, J. and Andrewartha, M. G. (1948) J. Anim. Ecol. I7, 2, 200-22. Davies, O. L. (I949) Statistical Methods in Research and Production (Oliver \& Boyd, London).

Elton, C. S. (1927) Animal Ecology (London).

EzekIEL, M. (1930) Methods of Correlation Analysis (Wiley, New York. Later editions).

FisHeR, R. A. (1932) Statistical Methods for Research Workers (Oliver \& Boyd, London. Later editions).

Gunn, D. L. and Symmons, P. M. (1959) Nature, Lond., I84, No. 4696, I425. Kendall, M. G. (I952) The Advanced Theory of Statistics (Griffen, London). Moran, P. A.P. (1953) Aust. J. Zool., I, No. I,I63.

Savage, R. M. (1935) Proc. zool. Soc. Lond., I, 49-98.

Tinbergen, N. (r953) Social Behaviour in Animals (Methuen, London).

Tippetr, L. H. C. (1952) The Methods of Statistics (Williams \& Norgate, London). Winliams, C. B. (I95I) Trans. IXth Int. Congr. Entomol. I, 174-89. 


\section{Appendix I}

\section{STATISTICAL METHODS}

IN this, as in many other branches of biology, the phenomena are not sharp, and conclusions must be examined statistically, if possible, before they can be accepted. Throughout the book statistical tests have been mentioned, without giving details, because it was thought that mathematical arguments arc too obtrusive when inserted in a text intended to be read through as a continuous story. Chapter Io and this appendix contain the missing details. It has been assumed that the reader is familiar with the common statistical tests, and the main emphasis is on the particular way in which the tests have been applied to the data. The section dealing with the correlation analysis of the spawn dates has, however, been made rather more full, because the methods used do not seem to be familiar in this field.

\section{(a) The Significance of the Weight Variations in the Colonies of TADPOLES}

The occurrence of large weight differences was so common in the field that no doubt was felt about the significance, but while the work was in progress some calculations of $t$ were made, and significant values were often found. When many collections are examined in this way, however, this test is, as is well known, not very satisfactory, because in a uniform population one in twenty collections will turn out significant merely by chance, if $t$ is taken at the 0.05 level. In fact, far more than one in twenty were significant, but this hardly makes the test a good one. The numbers of tadpoles in the collections were not always the same, and the habits of the tadpoles and the vagaries of weather often prevented the symmetrical design so desirable for an analysis of variance, but this analysis was not impossible, and was applied to the results for Dagger Lane, I947.

It seems obvious that it is the relative wcights, expressed as a proportion, which is important. For example, a colony of tadpoles with an average weight of $800 \mathrm{mg}$ differs from one of $600 \mathrm{mg}$ by a similar difference to that found between colonies with weights of 60 and $80 \mathrm{mg}$, and not by one ten times as great. A transformation of all the weights to logarithms was therefore made, and had at the same time the desirable result of stabilizing the variances in the colonies, which were getting heavier as the season advanced.

There were two criteria of classification: sites, and dates when the various collections were made. The date classes were sub-classifications of the site classes, and the variances due to date, so far as it was not already eliminated by 
the transformation, was removed in the analysis as irrelevant. Sometimes two collections had been made on a certain date, and sometimes three, so that the analysis was not quite simple, but a suitable scheme was found in Davies (1949), p. IO2, Appendix $s D$. The analysis was as follows, the figures being logarithms to two decimal places multiplied by roo to remove the decimals.

\begin{tabular}{|c|c|c|c|c|}
\hline Source of Variation & $\begin{array}{l}\text { Sums of } \\
\text { Squares }\end{array}$ & $\begin{array}{l}\text { Degrees of } \\
\text { Freedom }\end{array}$ & Variance & $\begin{array}{l}\text { Variance } \\
\text { Ratio }\end{array}$ \\
\hline $\begin{array}{l}\text { Between sites } \\
\text { Between collections within sites }\end{array}$ & $\begin{array}{r}5,624 \\
29,155\end{array}$ & $\begin{array}{r}2 \\
15\end{array}$ & $\begin{array}{l}2,812 \\
1,930\end{array}$ & $\mathrm{II} \cdot 6$ \\
\hline $\begin{array}{l}\text { Total between collections } \\
\text { Within collections (error) }\end{array}$ & $\begin{array}{l}34,779 \\
34,162\end{array}$ & $\begin{array}{r}\mathrm{I} 7 \\
\mathrm{I} 42\end{array}$ & 240 & \\
\hline Total. & $68,94 \mathrm{I}$ & I 59 & & \\
\hline
\end{tabular}

The variance ratio is significant at more than the I per cent. Dagger Lane Pond is not remarkable for the size of the variations, and there is no reason to suppose that similar analyses on other ponds would be any less significant. No doubt remains about the reality of the colony differences.

The numerical data for this table and the other weights of tadpoles have not been published, for the amount is voluminous, but they can be found in the library at London University in the $\mathrm{PhD}$ thesis entitled 'The ecology of anuran tadpoles' (I950).

(b) The Distribution of Polystoma integerrimum in TAdpoles

If a population of tadpoles were uniformly exposed to infestation by swimming larvae, which entered the tadpoles at random, it might be expected that the number of parasites in the tadpoles would be distributed according to the Poisson series, so that the number of tadpoles with $0, \mathrm{I}, 2,3, \ldots n$ parasites would be in the proportions given by the terms of the expression:

$$
e^{-m}\left(\mathrm{I}, m, \frac{m^{2}}{2}, \frac{m^{3}}{3}, \ldots \frac{m^{n}}{n}\right)
$$

where $e$ is the base of natural logarithms, and $m$ is the mean number of parasites.

Using the data from three ponds Upper and Lower Parkfield and Hospital, all in 1948 , the numbers calculated from this expression are given in Table I, together with the numbers actually found.

In each case, the large excesses in the first and last classes give such high values for $\chi^{2}$ that the corresponding values for the probability are beyond the range of the usual tables. It is impossible to regard the way in which the parasites are distributed as being due to random causes. 
TABLE I

FREQUENCY OF OCCURRENCE OF LARVAE AND NEOTENICS IN POPULATIONS OF TADPOLES SOME OF WHICH ARE INFESTED

\begin{tabular}{|c|c|c|c|c|c|}
\hline \multirow{2}{*}{$\begin{array}{c}\text { Larvac } \\
\text { Numbering }\end{array}$} & \multicolumn{2}{|c|}{ Numbers of Tadpoles } & \multirow{2}{*}{$\begin{array}{l}\text { Neotenics } \\
\text { Numbering }\end{array}$} & \multicolumn{2}{|c|}{ Numbers of Tadpoles } \\
\hline & Expected & Found & & Expected & Found \\
\hline $0-4$ & $8 \cdot 93$ & 132 & 0 & $52 \cdot 4$ & I 43 \\
\hline 5 & $I 1 \cdot 25$ & 5 & I & 80.95 & 40 \\
\hline 6 & I $8 \cdot 3$ & 14 & 2 & $63 \cdot 8$ & 17 \\
\hline 7 & $25 \cdot 6$ & 13 & 3 & $3 I \cdot 6$ & 17 \\
\hline 8 & $3 I \cdot 00$ & 3 & 4 & $12 \cdot 20$ & 5 \\
\hline 9 & $32 \cdot 51$ & I0 & $5-18$ & 4.05 & 23 \\
\hline I0 & $3 I \cdot 00$ & 8 & & & \\
\hline II & $29 \cdot 10$ & 5 & & $245 \cdot 00$ & 245 \\
\hline 12 & $23 \cdot 80$ & 3 & & & \\
\hline 13 & $17 \cdot 90$ & 4 & & & \\
\hline I4 & 12.55 & 7 & & & \\
\hline Is & $8 \cdot 20$ & 3 & & & \\
\hline 16 & $4 \cdot 97$ & 5 & & & \\
\hline \multirow[t]{2}{*}{$17-23$} & 5.89 & 49 & & & \\
\hline & $26 I \cdot 00$ & $26 I$ & & & \\
\hline
\end{tabular}

$m=9 \cdot 76$

$\chi^{2}$ for this distribution $=2,126$
$m=\mathrm{I} \cdot 54$

$\chi^{2}$ for this distribution $=292$

(c) The Relations between the Size of the Tadpoles and the PrESENCE OF NeOtenics

TABLE 2

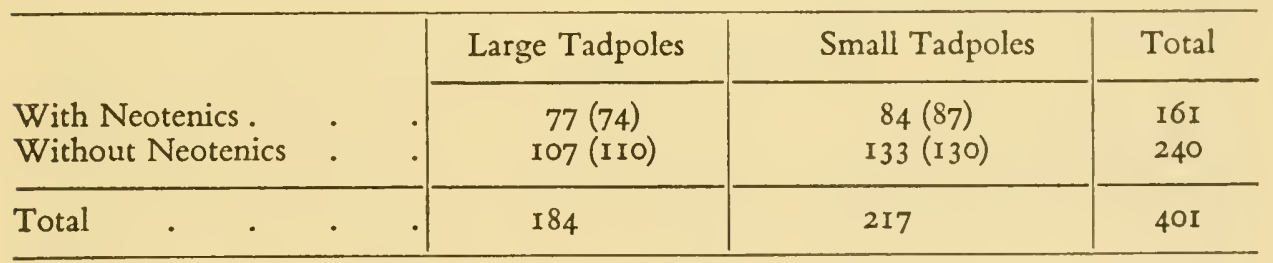

The numbers in brackets are those expected if the distribution had been random. $\chi^{2}$ for this distribution $=0.37$, and the probability of this happening by chance is more than 0.5 . There is no significant connexion between presence of neotenics and size of the tadpoles.

(d) The Significance of the Association of Frog-ponds with Geology

In this and other contingency tables, the figures in brackets arc those expected on the hypothesis that there is no relation between the variables. 


\begin{tabular}{ll|c|c|c}
\hline & & London Clay & All Other Formations & Total \\
\cline { 2 - 4 } Spawn observed. & $\cdot$ & $\begin{array}{c}30(5 \mathrm{I}) \\
\text { I60 (I39) }\end{array}$ & $\begin{array}{c}58(37) \\
77(98)\end{array}$ & $\begin{array}{r}88 \\
237\end{array}$ \\
\hline Total & $\cdot$ & I90 & I35 & 325 \\
\hline
\end{tabular}

$\chi^{2}$ for this distribution is 28.3 . The value of $P$ is beyond the range of the usual tables, so that there is no question about the significance.

(e) The Significance of the Association of Frog-Ponds With the Chemical Composition of the Water

Only the significant associations are given here. Other tables showing the absence of relations with other ions are in the 1939 paper. The correspondence with chance in these cases was very close.

\section{Potassium}

The level chosen for testing was I 8 parts per million.

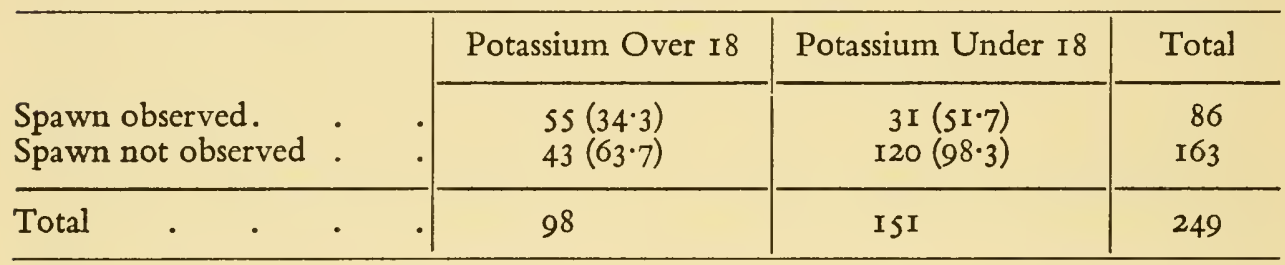

$\chi^{2}$ for this distribution is $3 \mathrm{I} \cdot 6$, and so is beyond the range of tables.

\section{Carbonate}

The level chosen for testing was 30 parts per million.

\begin{tabular}{|c|c|c|c|c|c|}
\hline \multirow{2}{*}{\multicolumn{2}{|c|}{$\begin{array}{l}\text { Spawn observed. } \\
\text { Spawn not observed }\end{array}$}} & & Carbonate Over 30 & Carbonate Under 30 & Total \\
\hline & & & $\begin{array}{l}71(60 \cdot 5) \\
99(109 \cdot 5)\end{array}$ & $\begin{array}{l}\text { I8 (28.5) } \\
64(53.5)\end{array}$ & $\begin{array}{r}89 \\
163\end{array}$ \\
\hline Total & . & . & I70 & 82 & 252 \\
\hline
\end{tabular}

$\chi^{2}$ for this distribution is 8.7 . This is significant at more than the 0.01 level. (There are numerical errors in the table on p. II of the I939 paper, fortunately with no effect on the conclusions.)

\section{( $f$ ) Significance of the Difference in the Phosphate Content of SPawn and Non-SPawn Ponds}

In this case, there were numerous analyses of the two groups of ponds. The principal interest centres on the values in the last three weeks of March, when most of the spawning occurred. Tested by calculating $t$, which was $s \cdot 8$, 
with 54 degrees of freedom, this is far more than is necessary for significance, even at the 0.001 probability level.

The significance could also be assessed by inspection, for the probability of fourtecn consecutive differences being all in the same direction by chance is negligible.

\section{(g) A Method of Calculating the Minimum Tadpole Mortality}

from the Observed Rate of Infestation by Polystoma integerrimum

This method depends on the truth of a number of assumptions, and it is not claimed to be accurate. The assumptions would have to be very far wrong to give a general picture much different from that suggested, and any errors are probably minus.

The parasite lays fewer eggs than its host. The mature fluke lays 400 to 800 eggs, and is hermaphrodite. A female frog lays, say, I,500 to 3,000 cggs, that is an average of $\mathrm{I}, \mathrm{I} 25$ per frog, but its parasite lays 600 . Since the host and its parasite start life at the same time, such a state of affairs must result in extinction of the parasite unless either the parasite has a mortality less than that of the frog, or there is a multiplying form that functions at an early stage, because by the usual axiom, if the population of frogs is stable, the number of its eggs just balances the mortality of the frogs. Now, a parasite that dies with its host must have a higher mortality, for its own causes of death must be added those of its host. The exact figure is unknown. In the face of this uncertainty, let us make the extreme assumption that the mortality of the parasite up to the moment that it enters the tadpole is nil. The multiplying form does not function until late in tadpole life. Gallien considers that 25 per cent of frogs carry an adult fluke. The parasites would therefore lay about 150 eggs per frog. If all the tadpoles survived to the age at which infestation begins, there would be I,I25 tadpoles for I 50 larvae, that is, O.I3 per tadpole. This was about the number in Lower Parkfield in 1947, and, at Dagger Lane in 1947, the number was lower. It will be recalled that, in those ponds in that year, tadpole mortality was exceptionally low, so that the calculation, theoretical as it is, holds so far. In all other cases, the number has been higher, and sometimes not even of the same order. For example, the number was 26 in Upper Parkfield and 6.4 in Cat Hill in 1948. It is therefore clear that there are sometimes a hundred times as many parasites as the hypothesis suggests, and there does not seem room for an error of this size in the numbers of parasites. It is probably the mortality among tadpoles that accounts for the high figures of infestation. This mortality can be calculated as follows-

Divide the number of parasites found by the calculated infestation, O.I3. The result is the reciprocal of the fraction of the original number of frog's eggs that survive to be tadpoles at the age when they are infested. For cxample, at Dagger Lane in I948, the number of larvae was $26.26 \div 0 . I_{3}=200$. Therefore 
I tadpole in 200 survived. At Cat Hill, the number was about I in $50 . \mathrm{My}$ estimate by eye of $I$ in 100 was perhaps not far out.

\section{(h) Statistical Significance and Importance}

The methods of computing correlation coefficients require no comment but the distinction between the statistical significance and the importance is sometimes overlooked. Many natural phenomena are very weakly correlated, but, because there is so much data available, there is no doubt about the significance. For example, everyone knows that in the winter there is a tendency for warm and wet weather to occur together, but in fact the correlation is weak. There comes a point when in such a case the relation, although it is based on such a large sample that it is certainly significant, is so loose that it really does not matter much, for it accounts for too small a proportion of the total variance. Increasing the quantity of data of the same kind may sometimes move a correlation from insignificance to significance, but unless the new data also raise the correlation, which in general is unlikely, the factor will remain unimportant, however certain its existence may be.

\section{(i) Migration Relation with Wind}

The test of significance follows standard methods. After calculating the expected numbers, so that the total is divided in the proportion that the winds occurred, and combining the neighbouring values so that no group was less than five, the differences of the observed and the expected values was taken and squared. Each of these numbers was divided by the number expected, and the sum is $\chi^{2}$. In this case it was $97 \cdot 6$, and, for seven degrees of freedom, this is far more than is necessary for significance. There is no reasonable possibility that the observed connexion is due to chance.

\section{Curvilinear Correlations}

The method used here can be found in Ezekiel (I930), Chapter I6. Briefly. It consists of plotting one variable, such as temperature, against migration and drawing a rough curve by eye to correspond to the points. The departures of every point from this curve are then plotted on another graph, with the next variable as one axis. Another curve is drawn. The process is continued until all variables have been plotted. The departures of the points from the last curve are then plotted on a fresh graph which has the first curve drawn upon it, as departures from this line, and correct the shape of this curve. The process goes on and may be repeated a third time or even more. The final result is that each curve is shown as if all the other factors were constant. The process can deal with curves of any shape with equal ease, it is simple to carry out, makes no mathematical assumptions as to the functions and in such a case as this takes only a few hours to do. 
The wide scatter of the points showed that there was some factor at work not included in the study. Part of the argument in favour of including the curves here, instead of merely suppressing them as not significant, depended on the realization that, if the wide scatter was due to some random error in the measurement of migration, the regression would not be different, since random errors in the dependent variable only alter the correlation. In spite of the unsatisfactory scatter of the points, it is therefore quite possible that the curves as drawn do represent the facts, overlaid by a random error. They agree well with ordinary practical experience.

(j) Contingency Tables for the Associations between the Weather at the Spawn Date and Spawning

(a) Rainfall

\begin{tabular}{|c|c|c|c|c|}
\hline & & Wet Days & Dry Days & Total \\
\hline $\begin{array}{l}\text { Spawn days } \\
\text { Non-spawn days }\end{array}$ & . & $\begin{array}{c}49(65) \\
\text { SII (495) }\end{array}$ & $\begin{array}{l}\text { I I I (95) } \\
709(725)\end{array}$ & $\begin{array}{r}160 \\
1,220\end{array}$ \\
\hline Total & - & 560 & 820 & 1,380 \\
\hline
\end{tabular}

(b) Dry Days and Wet and Dry Nights

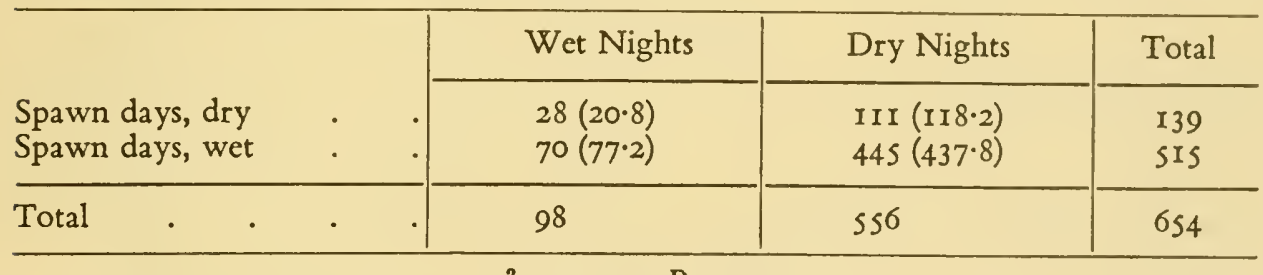

$$
\chi^{2}=3 \cdot 72 . \quad P=0.05
$$

(c) Temperature Above and Below $10^{\circ} \mathrm{C}$

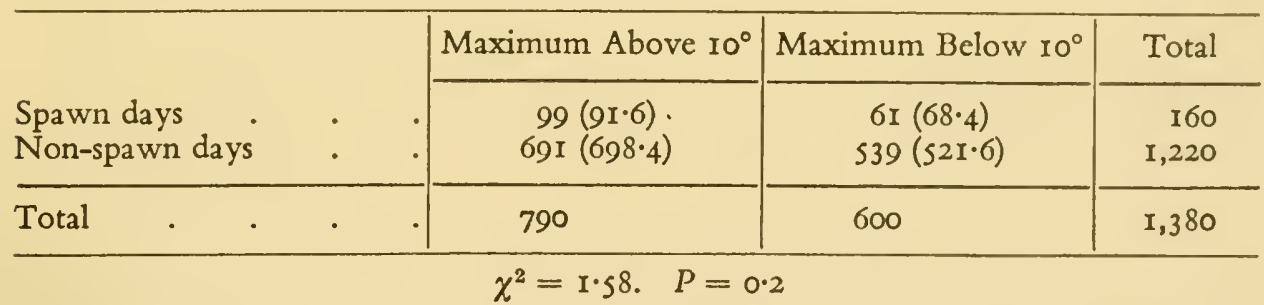

(d) Temperature Minimum Above and Below $0^{\circ} \mathrm{C}$

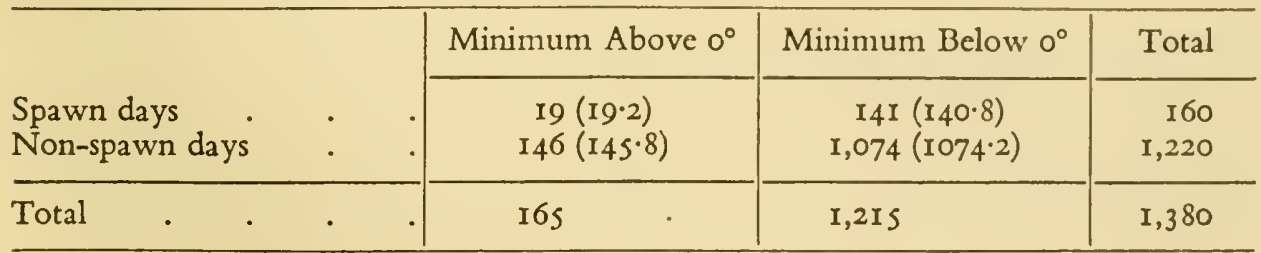

$$
\chi^{2}=0.003 . \quad P=0.90-0.95
$$


2 IO ECOLOGY AND LIFE HISTORY OF THE COMMON FROG

(e) Humidity 96 per cent or Over

\begin{tabular}{|c|c|c|c|c|}
\hline & & Humidity Over $96 \%$ & Humidity Under $96 \%$ & Total \\
\hline $\begin{array}{l}\text { Spawn days } \\
\text { Non-spawn days }\end{array}$ & • & $\begin{array}{c}68(66 \cdot I) \\
502(503 \cdot 9)\end{array}$ & $\begin{array}{c}92(93 \cdot 9) \\
718(716 \cdot I)\end{array}$ & $\begin{array}{r}160 \\
1,220\end{array}$ \\
\hline Total & . & 570 & 810 & $I, 380$ \\
\hline
\end{tabular}

$$
\chi^{2}=0.10 . \quad P=0.70-0.80
$$

(f) Humidity under 60 per cent

\begin{tabular}{|c|c|c|c|c|}
\hline & & Humidity Under $60 \%$ & Humidity Over $60 \%$ & Total \\
\hline $\begin{array}{l}\text { Spawn days } \\
\text { Non-spawn days }\end{array}$ & . & $\begin{array}{c}\text { SI (66) } \\
\text { SI9 (504) }\end{array}$ & $\begin{array}{l}109(94) \\
701(716)\end{array}$ & $\begin{array}{r}160 \\
1,220\end{array}$ \\
\hline Total & • & 570 & 810 & 1,380 \\
\hline
\end{tabular}

$$
\chi^{2}=6.55 . \quad P=0.01
$$


Appendix 2

\section{GLOSSARY}

ADIABATIC. Changes in a gas that take place without addition or subtraction of heat.

Adiabatic Lapse Rate. The temperature changes that result from alterations in the pressure of the air as the altitude is varied. Since these alterations are practically adiabatic, the changes are necessarily followed by temperature changes.

AlgaE. Aquatic plants, usually microscopic. For example, the grecn scums on water.

Amplexus. The clasping of the female by the male.

ANALYsis OF VARIANCE. A statistical procedure in which the total variance in a set of numbers is divided in such a way that the contribution of each group can be identified, measured and compared.

Aтrium. The chamber into which the gills of a tadpole project. Opens to the outside water by a narrow tube, the spiracle.

Beta Coefficients. The regression constant of an independent variable, multiplied by the standard deviation of that variable, divided by the standard deviation of the dependent variable.

Cercaria. One of the larval stages of a Trematode, parasites with very complicated life histories. Cercariae develop in snails, and usually find their definitive hosts later by swimming in the water.

Chi-SQuared, $\left(\chi^{2}\right)$. A measure of the difference between the actual observations and values calculated on some hypothesis.

Ciria. Microscopic, hair-like structures that serve to propel small animals by their wave-like motion, and in larger animals, move fluids over the surfaces of internal organs.

ClOACA. The common channel for urine and faeces.

Conlom. The main body cavity, in which many of the organs lie.

Correlation. A measure of the closeness of the relation between two series of numbers.

Correlation Coefficient. A statistic that expresses the closeness of the relation between two variables. $\mathrm{I} \cdot \mathrm{O}$ is perfect agreement, $0 \cdot 0$ is complete absence of agreement.

Correlation Coefficient, Curvilinear. A correlation coefficient computed on the assumption that the relation between the variables can be expressed as a curve. 
Correlation Coefficient, Partial. A correlation coefficient so computed that the effect of other variables has been eliminated.

Correlation Coefficient, Rectilinear. A correlation coefficient computed on the assumption that the relation between the variables can be expressed as a straight line. Often abbreviated to "linear correlation coefficient."

COVARIANCE. A measure of the variability in two sets of numbers, occurring in pairs. The mean of the products of the deviations from the respective means.

Crustacea. A family of animals including crabs, but in this context, "the water fleas" of fresh water.

Cysts. Resting stages.

DEGREES OF FreEDOM. The numbers of classes in a statistical classification that can be independently varied.

DeNSITY DEPENDENT FACTORS. Factors that affect animal populations so that the effects are greater when the population of animals is dense than when it is sparse.

Diatoms. Algae with a skeleton of silica.

Dihydrol. A polymer, consisting of two molecules of water, $\left(\mathrm{H}_{2} \mathrm{O}\right)_{2}$.

Distribution Curve. The curve obtained by plotting the frequency of an event against its magnitude.

ECOLOGY. The study of animals in their natural homes.

ENDOCRINOLOGY. The study of the glands of internal secretion and of the hormones they secrete.

ENZyme. An organic substance accelerating a biochemical reaction. In practice often essential for the reaction to occur at all.

Epizootic. Disease affecting numbers of animals. Corresponds to "epidemic" in humans.

FiBRIN. The thread-like insoluble protein forming the structure part of a bloodclot.

FibRINOGEN. A soluble protein in blood, forming fibrin when acted upon by thrombin.

FLuke. Trematode.

Food Chain. The chain of events such as this: Plant eaten by Animal A, Animal A eaten by Animal B, Animal B eaten by Animal C. . . .

GeL. Jelly. May become a sol. See "Sol."

GeotaXIs. Movement against gravity (negative), or with gravity (positive).

GLotTIS. The opening of the wind-pipe into the pharynx.

GonaDs. The organs producing eggs in the female or sperm in the male.

Haematology. The study of the blood.

Hibernacula. The winter quarters of animals that hibernate.

Homoiothermal ANimal. An animal that can regulate its internal temperature, within limits, independently of the external temperature. Birds and 
mammals are the only homoiothermal animals-all others are poikilothermal.

Hormone. A chemical messenger: a substance secreted by one organ that affects another after transport by way of the circulation.

Host, Definitive. In parasitology, the host that harbours the adult parasite.

INLIER. Patch of a geological formation lying on an area of another.

INVERSION. A metcorological condition in which the air becomes warmer as the altitude increases, instead of cooler, as is usually the case.

ISOPHENE. Line joining points of cqual date.

Joint Function. A statistical relation in which two or more independent variables interact so that the combined effect is different from the sum of the separate effects.

KINESIS. Random movement in response to a stimulus.

LARVA. A free-living stage of a young animal that differs, often very markedly, from the adult.

Metamorphosis. The change from tadpole into frog.

MetazoA. Multicellular animals.

Metacercarta. A stage in the life history of a trematode.

Microphagy. Feeding on microscopic food.

Multiple Correlation Coefficient. A correlation coefficient that expresses the closeness of the relation between a dependent variable and two or more independent variables.

NeOTENIC. An animal that attains reproductive maturity without having adult form.

NotochoRd. A rod of cartilage that in the lower vertebrates and also in tadpoles serves the same function as the backbone.

Oestrus. The sexual stage of a female animal.

Oesophagus. Gullet.

OlfaCTORY. Concerning the sense of smell.

Oligotrophic. An oligotrophic pond is one that has relatively little nutriment in it, and consequently relatively little life. Animals and plants that do occur are often specially adapted for the life there. Contrasts with "eutrophic." Frog ponds are usually, perhaps always, eutrophic.

OPERCULUM. Gill cover.

Orographical. Attribute to altitude.

Ovisac. The dilated part of the oviduct, where the eggs are stored between ovulation and oviposition.

Oviposition. The laying of eggs.

Ovulation. The discharge of vitelli from the ovary.

Pathogen. Agent of disease.

Perustaltic. Having a contractile motion in wave-like form that moves food along the alimentary canal. 
Phanerogams. The flowering plants.

Pharynx. The part of the alimentary canal between the mouth and the glottis.

Phenology. The study of the dates of natural events in the lives of animals and plants.

Phototaxis. Movement towards the light (positive), or away from it (negative).

Plankton. Animals or plants that float near the surface of the water.

Plasma. The liquid part of blood, in which the red cells float.

Poikilothermal Animal. An animal whose body is at or near the temperature of its environment, because it has no power of regulating its internal temperature.

POLYmer. A substance consisting of two or more simple molecules.

Precipitation. Rain, snow or hail.

PREDATORS. Animals that prey on other animals.

Protein. The main nitrogenous constituent of living matter.

Polystome. An Anglicized version of the name of the genus of trematodes, Polystoma.

Prothrombin. One of the substances in blood plasma that plays a part in the coagulation of the blood.

ProtozoA. Unicellular animals.

Regression Curve. Curve expressing the relation between two variables.

Regression Curve, Net. A regression curve from which the effect of other variables has been eliminated by statistical means.

RELEASER. In an animal, the signals that "release" sequences of behaviour.

Significant. In this book, always used in the statistical sense, meaning: "Not due to chance." Never used here as a synonym of "important."

Standard Deviation. A measure of variability. The square root of the variance.

Sol. A solution of a substance of high molecular weight, or of aggregates of simpler substances with a high total molecular weight. May become a gel. See ("gel").

SPECIES. The smallest clearly distinguishable unit in the classification of animals or plants.

SPIRACLE. The tubular exit from the atrium.

Symphysis PuBis. The junction between the pubic bones.

Thrombin. The enzyme, formed in blood, that reacts with fibrinogen to form fibrin.

Thromboplastin. A substance formed in blood when it clots.

Trematodes. Parasitic flat worms.

TruHydrol. A polymer, consisting of three molecules of water, $\left(\mathrm{H}_{2} \mathrm{O}\right)_{3}$.

Tropism. A turning reaction by an animal. 
VARIANCE. A measure of the variability in a series of numbers. The mean of the squares of the deviations from the mean.

Velum. Fold of tissue at the postcrior part of the pharynx of a tadpole.

Vitellus. That part of the egg that develops into the cmbryo. The black centre of the egg. 



\section{INDEX}

Abundance, fluctuations in, 79

Acanthocephalus ranae, indication of underwater feeding, 96

Aggregations of tadpoles, I9-23

bacterial population and chemical environment, 22

Air currents and migration, I05-6, IIO, II 4, II 5

Algae, 26-8, 30-I, 45-6, 49 enclosed in egg-jelly, I4

Algal hypothesis, 7 I, IO5, I I 3, I 39, I 44 Altitude, effect of on spawning, I42

Alytes obstetricarts, I9, I 67

Ambystoma maculatum, I 10

Ameel, 58

Amino-acids in tadpole nutrition, 47

Amplexus, drawings showing positions, $168-70$

Analysis-

correlation, I80-3, I86

of variance, 185

Anas plaryrhynchos, 87

Andrewartha and Birch, I77

Anurans, safety of life of, 86

Arcella, 46

Areas-

with abundant frogs, 78

with no frogs, 78

Aronson, I64, I73

Asellus aquaticus, indication of underwater feeding, 96

Atrium of tadpole, function of, 53

BAKER and Nasr, 45

Balcells, I, 5

Barnett, B., Io

Barrington, 45

Barthélémy, 97

Beach, I 20-I

Beak of tadpole, use of, 49

Behaviour, breeding, I60-75

Beta coefficients, I 44-5

Bierens de Haan, I 54

Biggs and Macfarlane, 70

Blair, 65

Blanchard, I 10

Bles, I9, 50
Blood-clotting, io

Bogert, I I I

Bombina-

bombina, I66

variegata, 5I, 95, I6I, I66, I72, I 73

Books, statistical, 182,183

Boulenger, 68, 97

Bragg, 68

Breder, Breder and Redmond, II I

British Herpetological Society, I I I

Brownlce, I 83

Budgett, I 44

Bufo-

bufo, 40, 44, 48, 5I, 67, 84-5, 96, II4, I6I, I7I-2, I 74

calamita, 68

terrestris, I I I

woodhousii, 68

Cambar, I9

Carbohydrate content of embryos, I 6 graph of, 17

Carp, digestion in, 45

Carpenter, 65

Catastrophes, regulators of abundance, I6, $32,38,39,40,80,81,87$

Cellulose digestion in tadpoles, 45

Cercariae, 58

Chapman and Chapman, III, II4

$\mathrm{Chi}^{2}, \mathrm{I} 85$

Chlamydomonas, $5 \mathrm{I}$

Computers, electronic, 178

Concrete, association with spawning, I $57-8$

Correlation-

analysis, 183

coefficients, partial, 194

coefficients of spawn date on weather,

I $43, \mathrm{I} 44, \mathrm{I} 46$

curvilinear, 208

Cott, 94, 96

Crustacea, digestion by tadpoles, 47

Cuckoo, 178

Cummins, III, I64

Cuticular teeth, use of, 49,50

Cyclops, 47

Czeloth, II 3 
DATA, biological large schemes, I7780

Davidson and Andrewartha, 92, I 8 I

Davies, I83

Deansley and Parkes, 42

Death ratein frogs, 85,86 in tadpoles, 207

Delayed spawning, effect on eggs, 8

Density-dependent factors in population control, 80-3, 9I-2

Density of population of frogs, 84

Dickerson, 5, 9, I4

Difflugia, 46

Digestion time in tadpoles, 44

Digestive anatomy and physiology of tadpoles, 49-53

Dihydrol, I36

Directiveness, I 54

Discoglossus pictus, 12

Disease, 88

Dismissal stimulus, I7I

Dissolved substances as food of tadpoles, 22

Distribution, I, 6-10

map, 2

of spawn dates in S.E. England, 147-8 of spawn in ponds, 72-6

Diver, 78

Dodd, 5 I

Dolk and Postma, 99

Douglas, I, 5, 7-8

Ducks as predators, $8 \mathrm{I}, 87$

\section{EGG-JELIY-}

ecological properties, I4-I5

heat storage in, 3-6

lack of nutritive properties, I6

thromboplastins in, IO-I4

\section{Eggs-}

delayed spawning, effect on, 8 numbers of, 82

thermal death points, I, 5

Elton, 196

Embyroscarbohydrate content, I6-I7 nitrogen content, 16, I 8

Endocrinology and the breeding cycle, I20-I

Enzymes-

digestive, 45

hatching, 19
Equation, prediction of spawn date by, 143

Euglena, 46, I 59

Euryhelmis, 58

External gills, function of, 2 I

Ezekiel, I83, I86, 192-3

FACT and hypothesis, 70

Faris, 88, I42

Fatio, 89, 97

Feeding habits, 96 underwater, 96-7

Fighting, $165-7$ drawing of, 167

Fischer-Sigwart, I, 88-9

Fish, 46

Fisher, I 50-I, I 83

Food-

chains, 47

for adults not a limiting factor, 84 of tadpoles, 44-9

Frazer, I I, I78, I 86

Fretter, 49

GaLliEN, 59, 64

Gallinula chloropus, I6, 39, 87

Gambusia, digestion in, 45

Gayda, 22

Geology-

map, 76

significance of the association of frog ponds with, 205-6

Giblett, I I4

Gill filters, action of, 52-3, 56

Gills, external, function of, 21

Glasspoole, 142

Glyphoglossus molossus, 56

Goldacre, 49

Graphs $v$. mathematical equations, 192

Gudernatsch and Hoffman, 47

Gunn and Symmons, I80-I

Halipegus eccentricus, 47

Hatching enzymes, 19

Hecht, 97

Hellf and Stubblefield, I9

Héron-Royer, 82, 97

Hibernation, 97-9

Hirudo medicinalis, 65

Hormones and the breeding cycle, I20-I

Huber, I65 
Humidity at the time of spawning, effects, I3I, 210

Hydrotaxis, I IO-I I

Hyla-

andersonii, $\mathrm{I} 74$

arborea, 68

nigropes, $\mathrm{I} 38$

rosenbergii, 22

Hypopachus aguae, 51, 53

Hypothesis and fact, 70

INDUSTRIAL areas, late spawning in, I $25-6$

Ireland, early spawning in, 125

Isophene map, I24

JAMES, I 38

Jameson, 84

Jelly envelopes, formation of, I2-I4

Joint functional regressions, 189 diagrams, I33, I35, I38, I40, I4I

Joyeux, 58

Jusczyk, 85 , III

Juveniles-

dispersal, 68

diurnal behaviour, 68

Kaloula borealis, 46

Kammerer, I 67

Kendall, I 84

Kratochwill, 5 I

Krizenecky and Podradsky, 22

Krogh, 22

LACK, $58,79-80,85$

Lantz, 68

Leeches as predators, $65-6$

$\mathrm{Li}$ and $\mathrm{Lin}, 46$

Light, influence on spawning, I 39

Limnodynastes tasmaniensis, foam nests, IS

Literature, use of, 198

Liu, I64

Locust plagues, I80-I

Loeb, I54

London clay, not favoured by frogs, 75

Lungs of tadpoles, 46, 48, 54, 55

Lynn and Edelmann, 42

MACAN and Worthington, 47

Macfarlane, Io
Maillcs, 97

Man as a predator, $82,88-9$

Map-

distribution, 2

isophene, $\mathrm{I} 24$

migration, IOI

Martof, 68, 85, II I

Mathematical equations $\nu^{\text {graphs, }}$ I92

Maturity, age of, 68

Medvedev, 54

Microhyla heymonsii, 53

Migration-

and air currents, I03, IIO, II4-5

compared with wind rose, 106

description of, $100, \mathrm{IO}_{2}$

map, Ior

and smell, II $2-13$

in snow, 108

stimulus for beginning, I I $5-16$

theories, IIO-IS

and voice, I I I-I 2

and weather data, $\mathrm{IO}_{4}$

and weather relations, $103-10$

wind direction and, I05-6, I IO

Moore, H., II4

Moore, J. A., 2, 5

Moorhens eating jelly, $16,39,87$

Moran, I 8I

Mortality of frogs and tadpoles, 85

Mucous cord feeding in tadpoles, $5 I$

Mud, as food for tadpoles, 46

Natrix natrix, as a predator, 88

Neal, 99

Nicholson, 90

Nitrogen content of embryos, I6, I8

Noble, 19, 22, I I I

Noble and Aronson, 173

Noble and Farris, 164, I73

Nuptial pads, function of, I66-7

Nussbaum, 8, I3

Nyctotherus, 58

\section{OBSERVATIONS-}

importance of trivial, 201

publications, 200

Occam's razor, I 53, I75

Opalina, 58

Oviposition, 8, I I, I68-70

Oxygen, dissolved, effects on tadpoles, I9, 20 
PARKer, E., 97

Pearly granulations, 165

Pearson, 84

Penman, I 39

Pet-keepers, techniques, 202

Phacus, 46

Phenological map, I24

interpretation, $123,125,126$

report, I22

Phenology, I77-8I

Phosphate-

graph of changes in, 77

relation to spawning and choice of pond, 77, 206

Poikilothermous effect, II7-I 8

Pollution, favourable to spawning, I 59

Polygamy, functional, I60

Polyplacophora, so

Polystoma integerrimum-

change of larvae into neotenics, 59$60,64-5$

distribution in tadpoles, $63,204-5$

effect of on size of tadpoles, 63, 205

epizootics in tadpoles, 59-66

epizootics, graphs of, 6I-3

population density as measure of

tadpole mortality, 207-8

Pond-finding, 197-8

Ponds-

spawn relation to chemistry, $75,77-$

$8,206-7$

spawn, relation to geology, $75-6$, 205-6

variation in use by frogs, $73-4,83$

Population-

in the Alps, 88

in Ireland, 88

Potassium, relation to choice of pond by frogs, 75, 206

Predators-

of frogs, $65,87-8$

of tadpoles, 65, 90

Pre-spawning period, I 56

Psychology of tadpoles, 4I-2, I 54

RAINFALI-

effect at the time of spawning, I273I, 209

effect of on spawn-date, I33-8, I40,

Rana-

I $43,145-8$

agilis, SI
Rana (contd.)-

aurora, I4

clamitans, 68, 85, II I

esculenta, 5, 8, 54, 85, II I

pipiens, I74

pretiosa pretiosa, 66

sylvatica, I 5, 42, 47, I73-4

terrestris, 174

Razor, Occam's, I 53, 175

Regression analysis of spawn dates, 142

Releasers, I7I

Respiration in tadpoles, 19-22, 53-6

Robins, mortality compared with that of frogs, 85

Roesel von Rosenhof, 86, I 59

Rovzewska, 98

Rowan, I2I

Royal Meteorological Society, 122, 177

Rugh, I3

"Run-off", I45, I47-8

Russel, E. S., I 54

Russel, W. M. S., I64, I7I

Scaphiopus holbrookii, 84-5

Scenedesmus, 46

Scillium, digestion in, 45

Seurat, 9

Sex recognition, I64-5, I72-5

drawing showing male and female, I72

Significance, statistical and importance, distinction, 208

Smell of water due to algae, 72 , II3, I $48-9$

Smith, C. L., 96, I20

Smith, M. A., 68, 85, 87, 94

Snakes as predators, 87

Sokolov and Chvaliova, 45

Solomon, 9I-2

Spallanzani, 9

Spawn dates-

distribution in S.E. England, I47 map, I48

negatively skewed, 147-8, I95

in British Isles, I23-6

map, I24

Spawn ponds-

events in, I60-3

relation of chemistry of water to, 75 ,

77-8, 206-7

relation of geology to, 76, 205-6 
Spawning-

associations with weather, I 26-9, I 3 I-47, 209

choice of site, I 57-8

influence of rain, temperature and sunshine on, 146

Sperm enission stimulus, I70-I

Strawinski, 53-4, 56

Subject, choice of, 196-7

Sunshine, influence on spawning, I40-I

Surface films as food for tadpoles, 32 , 47,49

Swammerdam, I2, I 59

Symura uvella, II 3

Syrroplius marnockii, 84

TABLES, $2 \times 2$, use of, I 84

Tadpoles-

aggregations of, 19-23

anatomy of, 48-53

attacks by leeches, $65-6$

behaviour of, $24-42$

cellulose digestion in, 44-5

C98, 46, 48, 55

differences in size in a pond, $25-42$, 203-4

digestive physiology, 44-7, 50, 52

digestive structure, drawings of, 48

diseases, 58-9

food of, 44-7, 49

growth rates, $25-42$

graphs, 25, 27, 29, 31, 33, 34, 36,

$37,38,39$

graphs in isolated populations, 39

lungs of, 54-6

drawings of, 48

mortality, method of calculating, using Polystoma infestation rates, 207

and Polystoma, relation of their life history, 59-64

predators of, 65

psychology, $4 \mathrm{I}$

respiration in, 53-6

effect on ecology, 56

shortage of food for, 40

significance of weight variations, 203-4
Tadpoles (contd.) -

young, nutrition, I $6-18,22$

young, tropisms, 20

Techniques in ecology, variety of, 196

Temperature-

and breeding cycle, I $2 \mathrm{I}$

effect at the time of spawning, I27-3 I

and rainfall, effect on spawn date, I 32-9, I 4 I

and sunshine, effect on spawn date,

I 4 I -2

Thermal death points, eggs, I, 5

Thomas, 47

Thromboplastins, IO-I I, I4

Tilapia, 46

Tinbergen, I54-5, I65, I74, I97

Tippett, 184

Trends, 196

Trihydrol, I36

Triturus helveticus, 78

Tropisms, 20, I 54

UNCLASPING stimulus, I7I

Underwater feeding, 96

VARIANCE, analysis, I83, I85

Velum of tadpole, 50-I

Veryard, II4

Voice-

female, 173

male, II I-I 2

Volpe, 9

Volvox globator, 44

WARING, Landgrebe, and Neill, I69, I75

Water composition, significance of the association of frogs-ponds with, 206-7

Water, rumning, spawning in, I 57-9

Weather and spawning, associations, statistical proofs, 209-10

Williams, I77, 178, I8I, 195

Witschi, 8

Wolterstorff, 97, 108

Wright and Wright, is

Xenopus laevis, I9, 42, 50-I, I64

ZELLER, 59, 64 

, 




